A desjudicialização na execução por quantia

Dissertação de mestrado

Orientação: Professor Doutor Ricardo de Barros Leonel

UNIVERSIDADE DE SÃO PAULO

FACULDADE DE DIREITO

SÃO PAULO-SP 
LUIZ FERNANDO CILURZO

\section{A desjudicialização na execução por quantia}

Dissertação apresentada objetivando Mestrado em Ciências, Programa Direito Processual Civil, na Universidade de São Paulo, sob orientação do Professor Associado Doutor Ricardo de Barros Leonel.

UNIVERSIDADE DE SÃO PAULO

FACULDADE DE DIREITO

SÃO PAULO-SP

2016 


\section{C572d Cilurzo, Luiz Fernando}

A desjudicialização na execução por quantia / Luiz Fernando Cilurzo ; orientador Ricardo de Barros Leonel -- São Paulo, 2016. $246 \mathrm{f}$.

Dissertação (Mestrado - Programa de Pós-Graduação em Direito Processual) - Faculdade de Direito, Universidade de São Paulo, 2016.

1. Execução. 2. Quantia certa. 3. Desjudicialização. I. Leonel, Ricardo de Barros, orient. II. Título.

CDD-347

CDU-347.9 
CILURZO, Luiz Fernando. A desjudicialização na execução por quantia.

Dissertação apresentada à Banca Examinadora do Programa de Pós-Graduação em Direito, da Faculdade de Direito da Universidade de São Paulo, como exigência parcial para obtenção do título de Mestre em Direito.

Aprovado em:

Banca Examinadora:

Prof. Dr. Instituição:

Julgamento: Assinatura:

Prof. Dr. Instituição:

Julgamento: Assinatura:

Prof. Dr. Instituição:

Julgamento: Assinatura: 
À Fabiana, por ser essencial em tudo. 


\section{AGRADECIMENTOS}

Ao Professor Ricardo de Barros Leonel, que me abriu as portas da Faculdade de Direito do Largo São Francisco.

Aos meus amigos Renato, Deny, Tito, Eliana, Bruno, Ícaro, Gabriela, Douglas, Fábio, Barel e Vicente, que, de uma forma ou outra, contribuíram, apoiaram e incentivaram esse projeto, sem os quais tudo seria mais difícil.

Aos membros e servidores da Promotoria de Jundiaí, fundamentais para que fosse possível o aproveitamento deste curso.

E aos meus pais, por cada passo, desde o primeiro. 


\section{RESUMO}

CILURZO, Luiz Fernando. A desjudicialização na execução por quantia. 2016. 246 f. Dissertação (Mestrado) - Faculdade de Direito, Universidade de São Paulo, São Paulo, 2016.

Este trabalho estuda a desjudicialização da execução por quantia enquanto técnica de aceleração do processo, de modo a avaliar sua possibilidade e funcionalidade para a melhora da atual crise de sobrecarga enfrentada pelo Poder Judiciário. O trabalho apoiou-se principalmente em revisão bibliográfica, análise de dados estatísticos e em pesquisa de campo realizada junto a um cartório judicial. Está dividido em três capítulos, dispostos da seguinte forma. O primeiro capítulo desenvolve o conceito de desjudicialização da execução para, em seguida, analisar o histórico e momento atual das codificações brasileiras de processo civil, identificando, em cada caso, movimentos de desjudicialização. Posteriormente, pontua os principais aspectos do devido processo legal atual que têm relevância para o estudo da desjudicialização. Após, analisa os dados estatísticos acerca da sobrecarga do Poder Judiciário, dando ênfase ao impacto dos processos executivos nos gabinetes e cartórios judiciais. O segundo capítulo estuda procedimentos executivos esparsos do ordenamento brasileiro que também fazem uso da desjudicialização, bem como a utilização da técnica em ordenamentos estrangeiros. O terceiro e último capítulo analisa, primeiramente, de modo geral e abstrato, qual a viabilidade de se utilizar as diversas formas de desjudicialização à luz dos aspectos relevantes do devido processo legal destacados no primeiro capítulo. Finalmente, com base no diagnóstico de sobrecarga do Poder Judiciário do primeiro capítulo, aponta as características e os principais elementos para se aplicar a desjudicialização de forma mais incisiva no procedimento geral de execução por quantia, de modo a contribuir com a melhora da crise de morosidade enfrentada pelo Poder Judiciário. De forma conclusiva, pode-se dizer que a desjudicialização é técnica compatível com o devido processo legal e que uma iniciativa desjudicializada que crie uma alternativa para os cartórios judiciais pode ser um primeiro passo para que, dentre outras melhorias, seja possível um progressivo alívio no fluxo de processos levados ao Judiciário

Palavras-chave: Direito Processual. Execução. Quantia certa. Desjudicialização. 


\begin{abstract}
CILURZO, Luiz Fernando. The de-judicialization of debt enforcement. 2016. 246 f. Master - Faculty of Law, University of São Paulo, São Paulo, 2016.

This study analyzes the possibility and functionality of the de-judicialization of debt enforcement as a technique to accelerate the procedure, with the purpose of reducing the overload of court cases faced by the judiciary system. The study relied on extensive review of the literature, statistical data analysis and field research carried out in a notary public office. The text is divided into three chapters. The first one develops the concept of de-judicialization of the enforcement, with the subsequent analysis of the Brazilian codifications of the civil process through the history to the present, identifying, in each case, movements of dejudicialization. It also presents the main aspects of the present due process of law, that are relevant for the study of the de-judicialization and analyses statistical data on the court system overload, emphasizing the impact of the executive proceedings on chambers and notary public offices. The second chapter presents Brazilian sparse executive proceedings that also make use of de-judicialization, as well as the use of the technique abroad. The third chapter analyses, first, in a general and abstract point of view, the viability of using the different forms of dejudicialization, as per relevant aspects of the due process of law referenced in the first chapter. Finally, based on the diagnose of overload of the court system presented in the first chapter, it's appointed characteristics and main elements for the implementation of de-judicialization in a more effective way in the general proceeding of debt enforcement, as a way to reduce the lengthy of the Brazilian courts. Conclusively we can say that de-judicialization, is a technique that meets the due process requirements and represents a de-judicialized initiative that provides an alternative for the notary public offices, which may become a first step, among others, to a progressive relief in the flow of cases brought to the judiciary system.
\end{abstract}

Keywords: Procedural Law. Enforcement. Debt. De-judicialization. 


\section{SUMÁRIO}

\section{CAPÍTULO 01 - O MODELO BRASILEIRO DE EXECUÇÃO POR QUANTIA.... 17}

1.1. DESJUdICIALIZAÇÃO DA EXECUÇÃO: PREMISSAS E CONCEITOS .................................... 17

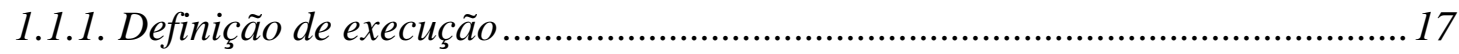

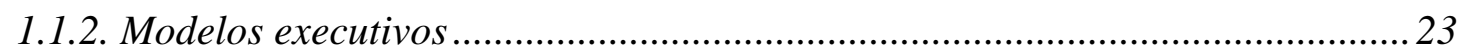

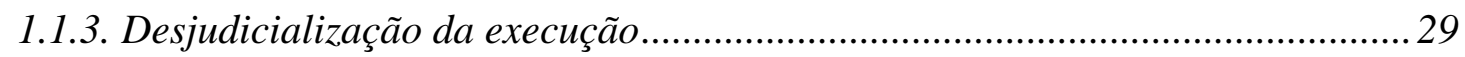

1.2. BREVE HISTÓRICO DA EXECUÇÃO BRASILEIRA POR QUANTIA ..................................... 32

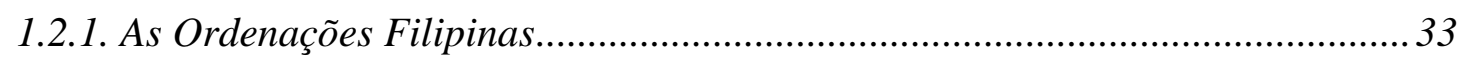

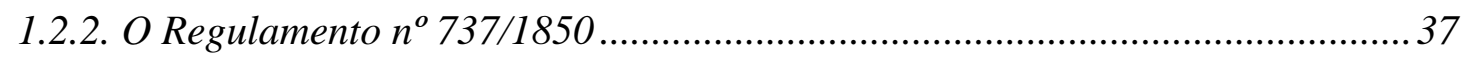

1.2.3. Os Códigos Estaduais e Código de Processo Civil de 1939 ............................... 40

1.3. O ATUAL REGRAMENTO GERAL DA EXECUÇÃO POR QUANTIA...................................... 43

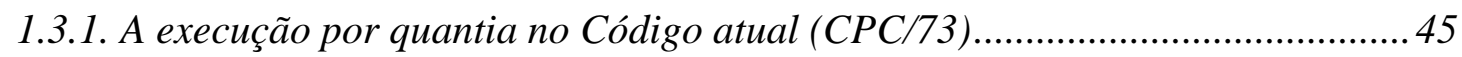

1.3.2. Alterações do Novo Código de Processo Civil (NCPC) ....................................... 55

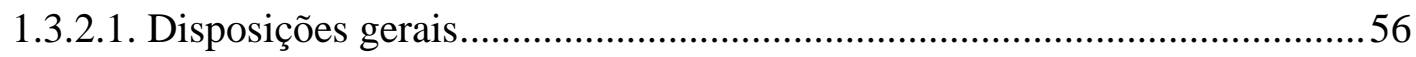

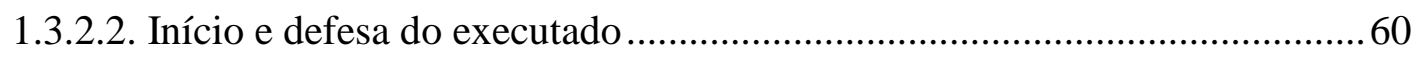

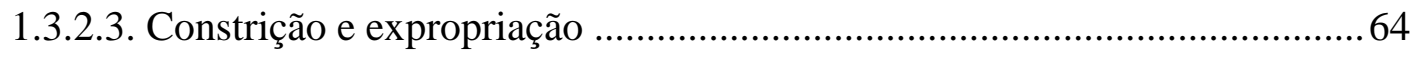

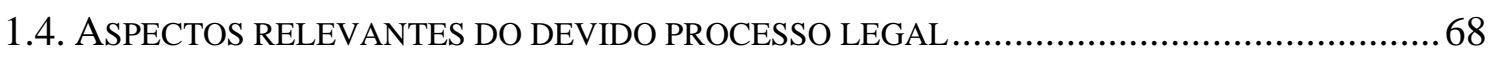

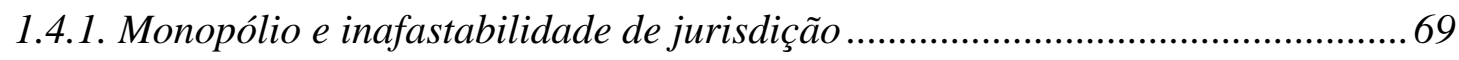

1.4.2. Imparcialidade e naturalidade do juiz e dos auxiliares ..................................... 72

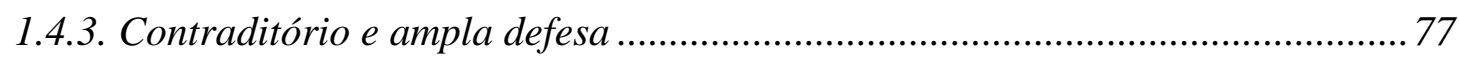

1.4.4. A razoável duração do processo executivo......................................................... 82

1.5. A SOBRECARGA DO PODER JUdICIÁRIO E A CONTRIBUIÇÃo DOS PROCESSOS

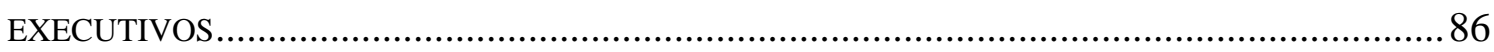

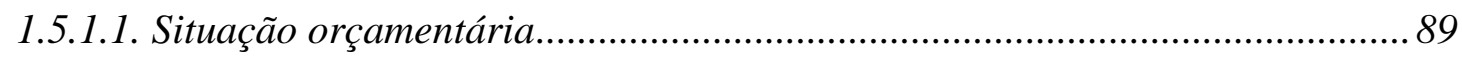

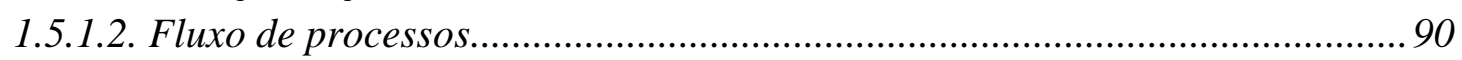

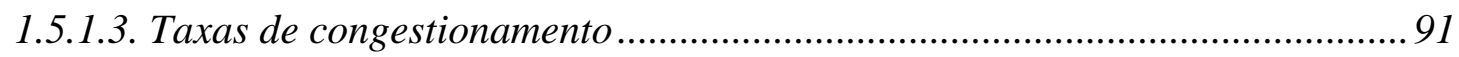

1.5.1.4. O impacto na vara e cartório judiciais............................................................. 93

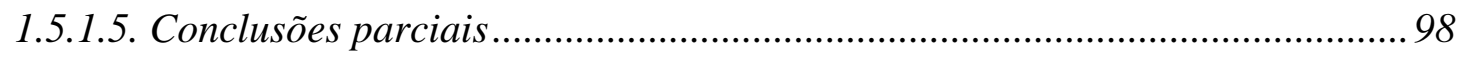

\section{CAPÍTULO O2 - A DESJUDICIALIZAÇÃO DA EXECUÇÃO POR QUANTIA NO QUADRO NORMATIVO CONTEMPORÂNEO..........................................................102}

2.1. PROCEDIMENTOS ESPARSOS DO ORDENAMENTO NACIONAL .................................... 102

2.1.1. O Decreto-Lei $n^{\circ} 70 / 66$................................................................................. 103

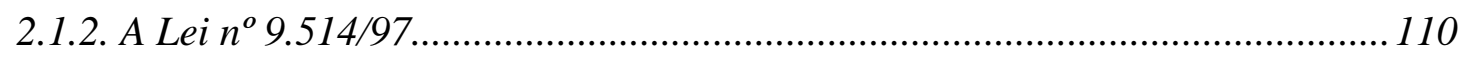

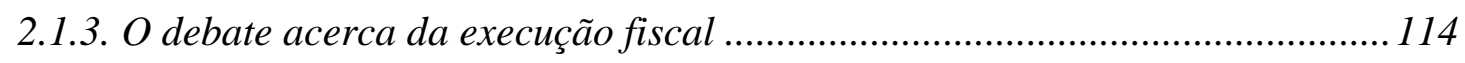

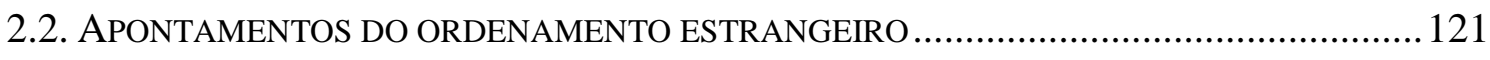

2.2.1. Modelos públicos judicializados............................................................... 123 


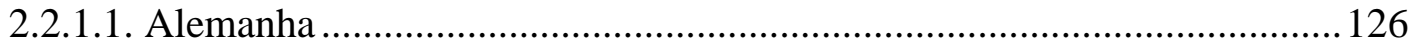

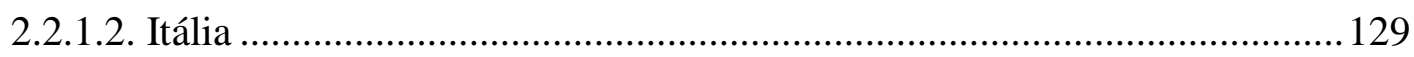

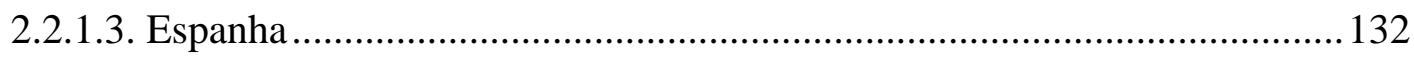

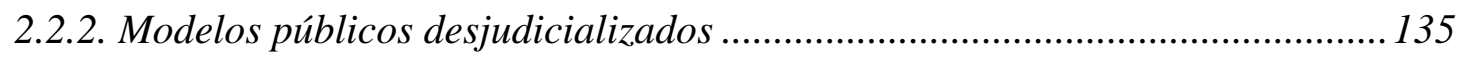

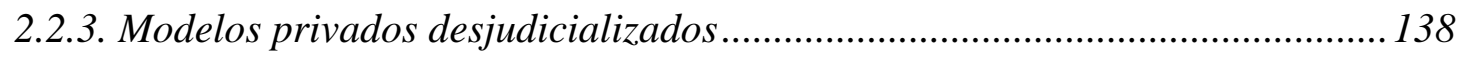

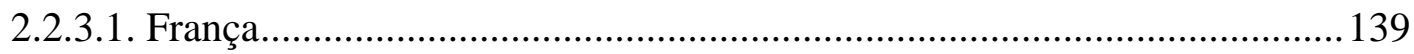

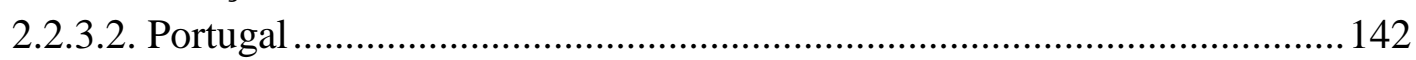

2.2.3.2.1. Os órgãos atuantes na execução....................................................... 145

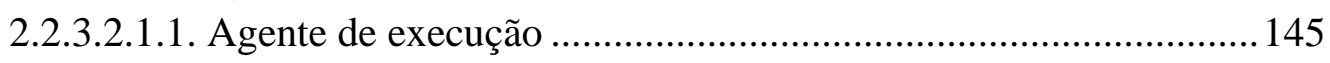

2.2.3.2.1.2. Juiz de execução ................................................................... 148

2.2.3.2.1.3. Comissão para o Acompanhamento dos Auxiliares da Justiça

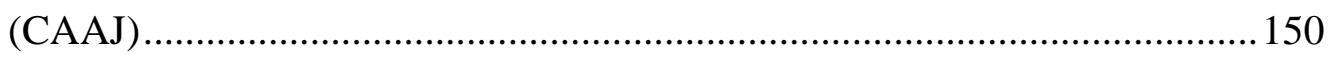

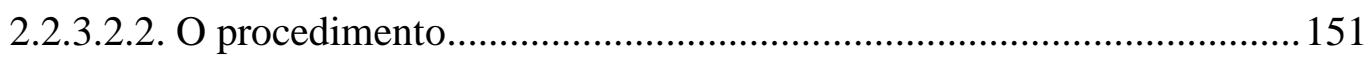

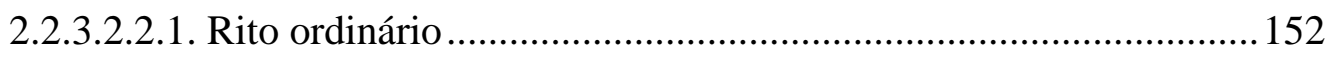

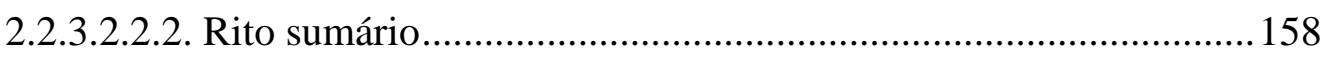

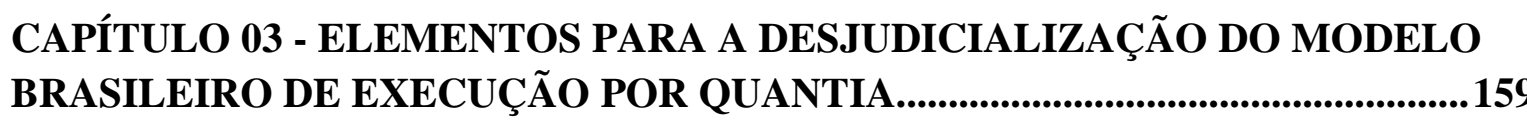

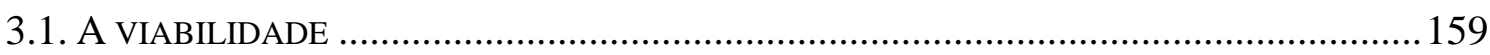

3.1.1. Monopólio e inafastabilidade de jurisdição ................................................... 160

3.1.2. Imparcialidade e naturalidade dos agentes envolvidos na execução.............. 172

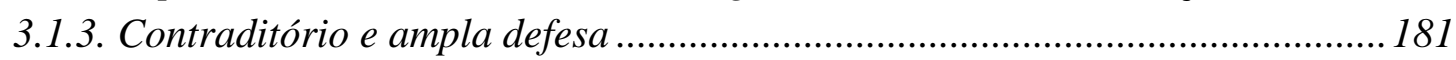

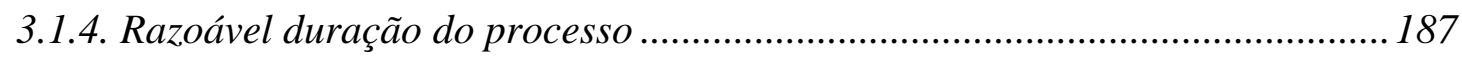

3.2. ELEMENTOS PARA UM MODELO DE EXECUÇÃO DESJUDICIALIZADA ........................... 193

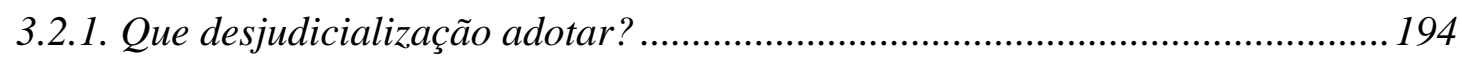

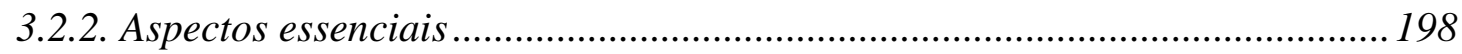

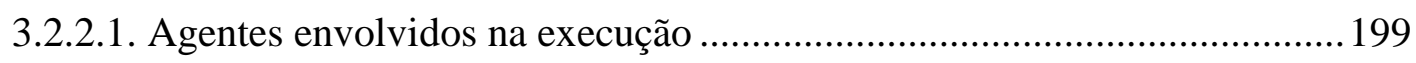

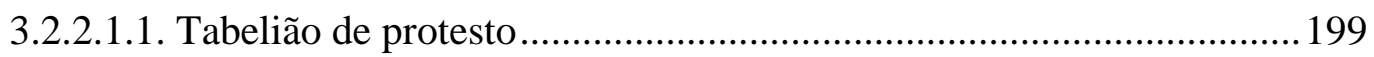

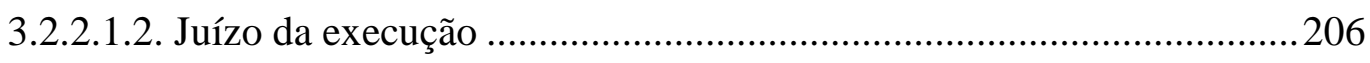

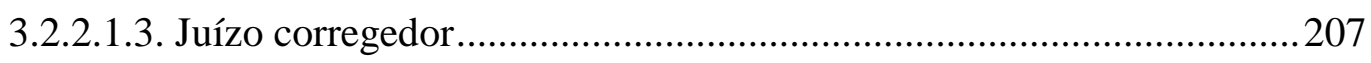

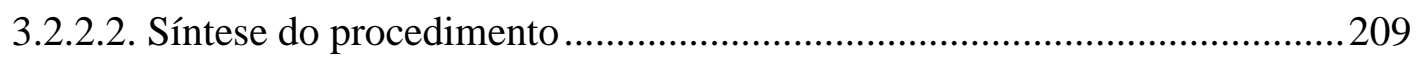

3.2.2.3. Proveito para a razoável duração do processo .........................................213

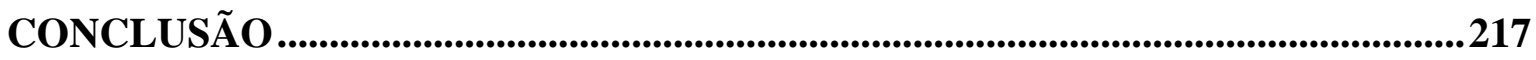

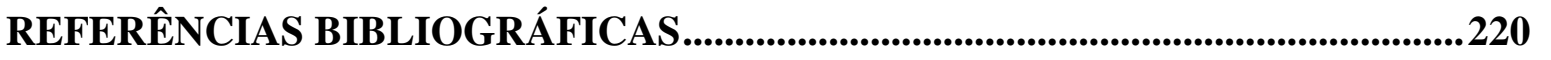




\section{INTRODUÇÃO}

As sociedades como a brasileira, pós-modernas, estabelecidas dentro de um Estado democrático, têm, como uma de suas principais características, a consolidação dos Direitos Civis, aí inclusa a ampliação do acesso à justiça ${ }^{1}$. A decorrência natural de tal aspecto é o aumento de relações jurídicas no âmbito civil e, com elas, o aumento de conflitos que demandam solução pelo Poder Judiciário² .

O crescimento do número de ações versando sobre questões civis, trouxe grande acúmulo de processos dessa natureza, cada vez mais complexos ${ }^{3}$. Diante desse quadro, a estrutura do Poder Judiciário brasileiro foi sobrecarregada, tornando cada vez mais lenta e inadequada a obtenção da tutela pretendida.

Dimensionando referido acúmulo, o relatório “Justiça em Números”, elaborado pelo Conselho Nacional de Justiça, identificou, apenas no ano de 2012, no âmbito das Justiças Estaduais, 19,06 milhões de processos de conhecimento e 26,68 milhões de processos de execução, todos não criminais, pendentes de resolução.

${ }^{1}$ CAMBI, Eduardo. Neoconstitucionalismo e neoprocessualismo. In: DIDIER JUNIOR, Fredie (coord.). Leituras complementares de Processo Civil. 8 ed. Salvador: Editora Juspodivm, 2010, p. 238.

2 Leonardo Greco acusa uma "exacerbação do demandismo", fruto da elevação de consciência jurídica do cidadão e do desenvolvimento tecnológico, que trouxeram a reboque uma intensificação das relações civis e de consumo (Novas perspectivas da efetividade e do garantismo processual. In: MITIDIERO, Daniel; AMARAL, Guilherme Rizzo (coord.). Processo Civil: estudos em homenagem ao Professor Doutor Carlos Alberto Alvaro de Oliveira. São Paulo: Editora Atlas, 2012, p. 277).

3 ALBERTON, Genacéia da Silva. Repensando a jurisdição conflitual. In: CARNEIRO, Athos Gusmão; CALMON, Petrônio (org.). Bases científicas para um renovado direito processual. 2 ed. Salvador: Juspodivm, 2009, p. 309; RIBEIRO, Darci Guimarães. La ejecución procesal civil: experiencia del derecho brasileño. In: CADENAS, Manuel Cachón; JUNOY, Joan Picó. La ejecución civil: problemas actuales. Barcelona: Atelier Libros Jurídicos, 2008, p. 372. 
Paralelamente, vive-se certo consenso doutrinário acerca do caráter instrumental do processo $^{4}$, pelo qual seu estudo e compreensão se dão não só de forma estanque e autônoma, mas também como meio - ou instrumento - que serve sempre a uma finalidade relacionada à efetiva satisfação do direito material e à pacificação social dos conflitos 5 .

Nesta concepção, a técnica processual passa a ser encarada como meio para se dar segurança ao processo, permitindo a participação e influência das partes na decisão final, garantindo que a tutela jurisdicional, na medida do possível, dê resposta idêntica àquela pretendida pela regra de direito material, tanto pelo aspecto da justiça da decisão, quanto pelo ângulo da tempestividade ${ }^{6}$. $O$ foco, portanto, volta-se para o conteúdo do processo ${ }^{7}$, abandonando-se a ideia da forma como um fim em si mesmo.

Se, na vigente concepção instrumental, o processo é mero meio para que se obtenha a satisfação de um direito material, o atual congestionamento de processos, ao trazer grande dificuldade e lentidão na vazão das demandas e satisfação dos direitos levados a juízo, transforma o processo em sua própria negação, na medida em que aquilo que deveria ser um caminho ao direito material acaba se configurando num empecilho.

\footnotetext{
4 Incidentalmente, convém salientar o entendimento da parte doutrinária que, sem prejuízo da instrumentalidade do processo, defende que se vive hoje uma fase além, tratada como neoprocessualismo, em que se agrega ao processo as características do neoconstitucionalismo, marcadamente o reconhecimento da força normativa da Constituição, da eficácia normativa dos princípios, do reconhecimento de papel normativo da atividade jurisdicional e da expansão e consagração dos direitos fundamentais (DIDIER JUNIOR, Fredie. Teoria do processo e teoria do direito: o neoprocessualismo. In: DIDIER JUNIOR, Fredie (coord.). Teoria do processo: panorama doutrinário mundial - Volume 2. Salvador: Editora Juspodivm, 2010, p. 258-260; SAMPAIO JÚNIOR, José Herval. A influência da constitucionalização do direito no ramo processual: neoprocessualismo ou processo constitucional? Independente da nomenclatura adotada, uma realidade inquestionável. In: DIDIER JUNIOR, Fredie (coord.). Teoria do processo: panorama doutrinário mundial Volume 2. Salvador: Editora Juspodivm, 2010, passim).

${ }^{5}$ LEONEL, Ricardo de Barros. Eficácia imediata da sentença e as reformas do CPC: um aspecto da caminhada para a efetividade da tutela jurisdicional. Justitia, São Paulo, v. 200, p. 125-143, 2009, p. 125.

${ }^{6}$ BEDAQUE, Jose Roberto dos Santos. Efetividade do processo e técnica processual. 3 ed. São Paulo: Malheiros, 2010, p. 78.

${ }^{7}$ LEONEL, Ricardo de Barros. Reformas Recentes do Processo Civil: comentário sistemático. São Paulo: Método, 2007, p. 15.
} 
Neste cenário, mandatória a busca por soluções que almejem um processo mais fluido

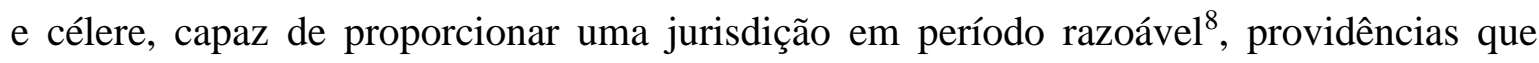
voltem atenção aos dois espectros temporais do processo civil: um primeiro, iniciado com a propositura de uma ação que busque reconhecer uma situação de direito material e encerrado com uma decisão definitiva declaratória, constitutiva ou condenatória sobre o alegado - o processo ou fase de conhecimento - e um segundo, iniciado com a propositura de uma ação que busque satisfazer uma pretensão já reconhecida em juízo ou por força de lei e encerrado com seu efetivo cumprimento - o processo ou fase de execução 9 .

Tais soluções possuem variada natureza e incidem sobre diversos aspectos. A fim de sistematiza-las, Fernando da Fonseca Gajardoni propôs três classes de técnicas de aceleração do processo $^{10}$ : as extraprocessuais, as judiciais e as extrajudiciais ${ }^{11}$.

As técnicas extraprocessuais, segundo o autor, não se ocupam do conflito a ser resolvido por meio do processo. Seu objeto é a busca por um maior rendimento do sistema judiciário em si, do aparato disponibilizado ao juiz para o exercício da função jurisdicional, tais como corpo de servidores, aparelhamento tecnológico de gabinetes e cartórios e a distribuição de funções dentro da estrutura do Poder Judiciário.

Já as técnicas judiciais, buscam soluções de celeridade em um conflito já processualizado no âmbito do Poder Judiciário. Seu foco é nos atos processuais que permeiam a relação jurídica processual estabelecida entre as partes e o Estado-Juiz. Buscam,

${ }^{8}$ SOUZA, Marlene Marlei de. A efetividade da jurisdição. Revista da Ajuris, Porto Alegre, Ano XXXVI, $\mathrm{n}^{\circ}$ 113, mar. 2009, p. 302.

9 TARZIA, Giuseppe. Il giusto processo di esecuzione. Rivista di Diritto Processuale, ano LVII, n. 2, abriljunho 2002, p. 349.

${ }^{10}$ Não se ignora certa divergência na doutrina acerca das classificações dos mecanismos de aceleração do processo. Contudo, uma análise detalhada de tais categorizações, ponderando vantagens e desvantagens de cada uma é descabida neste trabalho, sob pena de se desviar, com pouco proveito prático, o foco de seu objeto. Apenas para que a questão não reste intocada, fazemos remissão à análise do próprio Fernando da Fonseca Gajardoni que, após analisar as classificações de Cândido Rangel Dinamarco e José Rogério Cruz e Tucci, identifica suas incompletudes ao desconsiderarem a relevância de medidas externas ao processo e externas ao Poder Judiciário como meios de desobstruir a via judicial. Conclui, com isso, que o melhor caminho no combate à morosidade do processo é a combinação de estratégias que atuem interna e externamente à via processual, motivo pelo qual propõe a classificação ora adotada. (Técnicas de aceleração do processo. São Paulo: Lemos \& Cruz, 2003, p. 70 a 74).

${ }^{11}$ GAJARDONI, Fernando da Fonseca. Técnicas de aceleração do processo. São Paulo: Lemos \& Cruz, 2003, p. 75 e 76. 
pois, um processo judicial mais simples, rápido e econômico, capaz de prover o direito material o mais próximo possível de seu ideal projetado em lei. São exemplos de técnicas judiciais a abreviação procedimental, a tutela antecipada e a cassação do efeito suspensivo automático dos embargos à execução.

Estas duas primeiras classes de técnicas de aceleração do processo não serão objeto de análise direta neste trabalho. A proposta que será discutida a seguir guarda estreita relação com a terceira e última classe: as técnicas extrajudiciais.

São extrajudiciais as técnicas que visam desobstruir o Poder Judiciário e acelerar a solução de litígios retirando processos da via judicial, afastando-os do Estado-juiz. Para tanto, buscam-se medidas que estimulem a autocomposição extrajudicial, a autotutela ou transfiram a heterocomposição para entes externos ao Poder Judiciário.

Estas técnicas já vêm sendo estimuladas e empregadas no país. Principalmente no primeiro dos espectros temporais apontados acima - processo ou fase de conhecimento -, houve grande estímulo aos meios alternativos ao Poder Judiciário para a solução de conflitos, notadamente na promoção e utilização das câmaras de conciliação, mediação e arbitragem, bem como ao uso do inventário, partilha, separação e divórcio extrajudiciais ${ }^{12}$.

Quanto ao segundo lapso, entretanto, a constatação é diversa. Em que pese já haver precedentes no país, não se buscou o estímulo da execução fora do judiciário. De maneira geral, optou-se por técnicas judiciais, abreviando os procedimentos executivos já existentes, ou até mesmo extraprocessuais, aumentando os investimentos na estrutura do Poder Judiciário, mas sempre mantendo o processo executivo à vista do juiz.

O contraponto pôde ser observado em alguns países que enfrentaram situação semelhante. Em algumas nações da Europa, em especial, uma saída comum e muito difundida para diminuir a morosidade da execução, foi reduzir drasticamente a atuação do Judiciário, delegando até mesmo a direção e condução da execução a um terceiro, não-juiz,

${ }^{12}$ QUEIROGA, Onaldo Rocha de. Desjudicialização dos litígios. Rio de Janeiro: Renovar, 2012, p. 98. 
agente público ou privado, o chamado agente de execução. Praticou-se, em grande intensidade, a chamada desjudicialização da execução ${ }^{13}$, atitude que conta com a anuência e o incentivo dos principais organismos internacionais atuantes no continente europeu, casos do Conselho da Europa e da própria União Europeia.

Em Portugal, por exemplo, houve grande desjudicialização dos procedimentos executivos a partir da edição do decreto-lei no 38/2003. Como assevera Flávia Pereira Ribeiro, por meio desse decreto "houve a translação da competência do agente público historicamente encarregado pela execução - o juiz - para o solicitador de execução, profissional liberal designado especificamente para essa atribuição e sujeito a todas as responsabilidades dela decorrentes" ${ }^{\prime 14}$.

A solução pela desjudicialização da execução, à primeira vista, mostra-se como alternativa coerente com os problemas atualmente enfrentados pelo Poder Judiciário brasileiro à luz da sociedade do capital: o desonera de um de seus maiores contingentes processuais e pode, ainda, a depender da forma em que se dê, estimular uma nova atividade econômica, com reflexos arrecadatórios para o Estado. Não há motivo, pois, para deixar de considera-la ${ }^{15}$.

Não se pode olvidar, contudo, que sua adoção, no Brasil, encontra sérios obstáculos, concentrados, principalmente, no monopólio e inafastabilidade de jurisdição, na imparcialidade e naturalidade do juiz e no contraditório e ampla defesa, já que a relação entre as partes e a função jurisdicional se dará de modo distinto do atual ${ }^{16}$.

\footnotetext{
${ }^{13}$ A terminologia comporta discussões acerca de sua exata compreensão, motivo pelo qual o item inaugural do trabalho cuidará de delimitar e especificar a exata definição do termo. Para o momento, basta que se compreenda o sentido que se pretende atribuir: a redução da utilização do Judiciário na execução, quer seja apenas dos juízes, quer seja de toda a sua estrutura.

${ }^{14}$ RIBEIRO, Flavia Pereira. A desjudicialização da execução civil. São Paulo: Saraiva, 2013, p. 18.

${ }^{15}$ SICA, Heitor Vitor Mendonça. Efetividade da execução civil. Civil Procedure Review, v. 4, p. 161-190, 2013, p. 189.

${ }^{16}$ Como destaca Samy Garson, "qualquer meio alternativo de recuperação de créditos que porventura seja ventilado, inexoravelmente deverá compatibilizar a devida segurança jurídica e, no que couber, a igualdade de armas daqueles que ocuparão a posição de devedores com os credores" (A viabilidade da desjudicialização do
} 
Neste trabalho, buscaremos, inicialmente, caracterizar o atual modelo executivo por quantia certa contra devedor solvente empregado no Brasil, no intento de verificar se há e qual a amplitude de sua desjudicialização. Nestes termos, estudaremos a evolução legislativa da execução no Brasil, para então analisarmos o atual procedimento executivo brasileiro, tanto na atual codificação, quanto no Projeto de Novo Código ${ }^{17}$. Em seguida, estudaremos as principais bases do direito processual que sustentam o atual ordenamento e que tendem a ser mais sensíveis em eventual desjudicialização. Finalizando o primeiro capítulo, abordaremos a atual sobrecarga do Poder Judiciário e o impacto da execução neste cenário.

No segundo capítulo, analisaremos as iniciativas brasileiras de procedimentos executivos desjudicializados já implementados e a proposta de desjudicialização da execução fiscal, cujo debate vem ganhando força atualmente. Exploraremos, ainda, a estrutura dos modelos de execução estrangeiros mais influentes para o processo civil brasileiro, enfatizando aqueles que implantaram medidas de ampla desjudicialização, notadamente o português.

No terceiro e último capítulo, verificaremos a viabilidade de se implantar esta técnica no Brasil e, em sendo viável, quais os principais aspectos a serem considerados para, ao final, esboçarmos um modelo desjudicializado de execução civil por quantia certa contra devedor solvente que possa ser funcional ao diagnóstico de sobrecarga do Judiciário brasileiro.

Destaque-se que o recorte metodológico do tema restringe o objeto do trabalho à análise da execução não fiscal por quantia certa contra devedor solvente ${ }^{18}$. A uma, porque é o tipo de prestação mais comum - mesmo execuções de obrigações de fazer, não fazer ou dar coisa certa podem, em certo momento, serem convertidas em execuções por quantia

processo de execução. In: CARVALHO, Milton Paulo de (coord.). Direito processual civil. São Paulo: Editora Quartier Latin, 2007, p.22).

${ }^{17}$ Lei no 13.105 , de 16 de março de 2015, publicada no Diário Oficial da União em 17 de março de 2015 e com vacatio legis de um ano a contar da data de publicação, conforme seu artigo $\mathrm{n}^{\circ} 1.045$.

${ }^{18}$ Discriminação a partir do critério de classificação das execuções empregado pelo Código de Processo Civil, que leva em conta, principalmente, o direito material almejado pelo exequente - quantia, fazer, não fazer e dar - a partir do qual são moldados os meios executivos funcionais a ele. (BEDAQUE, Jose Roberto dos Santos. Direito e processo: influência do direito material sobre o processo. 6 ed. São Paulo: Malheiros, 2011, p. 144). 
certa. A duas porque, bem definido um modelo de execução desjudicializada por quantia certa, boa parte da estrutura poderá ser aproveitada para as demais espécies de execução.

Por fim, para que reste inequívoco, cabe destacar que o trabalho todo será pautado pela máxima da busca pela efetividade e tempestividade processuais, espécies de cláusulas gerais que ordenarão todo o raciocínio da pesquisa. 


\section{CAPÍtULOO 01}

\section{O MODELO BRASILEIRO DE EXECUÇÃO POR QUANTIA}

\subsection{Desjudicialização da execução: premissas e conceitos}

Conforme explanado no texto introdutório, a desjudicialização da execução não é matéria corriqueira da doutrina nacional. Sua abordagem sistematizada ainda é rara, sendo, por isso, necessário delimitar os conceitos que serão utilizados ao longo do trabalho a fim de se estabelecer parâmetros e premissas suficientemente claros.

Assim, nesta primeira parte do trabalho objetiva-se delimitar a noção de execução, para que em seguida se possa compreender em que consiste e em que sentido se enfrentará sua desjudicialização. Para a compreensão desta, serão apresentados os diferentes modelos de execução e a extensão em que será aplicado o termo desjudicialização.

\subsubsection{Definição de execução}

Para que se possa abordar a desjudicialização da execução, antes é necessário definir e delimitar aquilo que aqui será considerado como execução. A definição do termo é tratada pela doutrina de diferentes formas e em diferentes graus de especificidade. 
Da forma mais ampla possível, de rara controvérsia, pode-se dizer que executar é dar concretude a um preceito contido em lei, contrato ou sentença ${ }^{19}$, é realizar uma obrigação ${ }^{20}$. É, em entendimento tranquilo na doutrina, satisfazer uma prestação devida ${ }^{21}$.

Segundo Cândido Rangel Dinamarco, estaria contemplado neste conceito tanto as ocasiões em que o autor cumpre, espontaneamente, a obrigação devida - à qual denomina execução do contrato -, quanto aquelas em que o adimplemento se dá por imposição do Estado-juiz - à qual denomina execução forçada ${ }^{22}$.

Diante desta ampla acepção do termo, considerando que várias são as formas de se dar concretude a um preceito legal, faz-se necessário especificar esta definição.

Assim, com maior minúcia, Enrico Tullio Liebman definiu execução como a atividade "que tem por finalidade conseguir por meio do processo, e sem o concurso da vontade do obrigado, o resultado prático a que tendia a regra jurídica que não foi obedecida" 23 .

Destaca que o cumprimento espontâneo da obrigação não é abrangido pelo conceito, uma vez que não há atuação do órgão processual, mas sim do próprio obrigado, por livre determinação de sua vontade ${ }^{24}$.

${ }^{19}$ DINAMARCO, Cândido Rangel. Instituições de Direito Processual Civil - Volume IV. 3 ed. São Paulo: Malheiros, 2009, p. 34.

${ }^{20}$ DINAMARCO, Cândido Rangel. Execução civil. 8 ed. São Paulo: Malheiros, 2002, p. 105.

${ }^{21}$ Assim entendem DIDIER JUNIOR, Fredie; BRAGA, Paula Sarno; OLIVEIRA, Rafael; CUNHA, Leonardo José Carneiro da. Curso de direito processual civil - Execução - Volume 5. 4 ed. Salvador: Editora Juspodivm, 2012, p. 28; WAMBIER, Luiz Rodrigues; TALAMINI, Eduardo. Curso avançado de Processo Civil - Volume 2. 13 ed. São Paulo: Editora Revista dos Tribunais, 2013, p. 44; ASSIS, Araken. Manual da execução. 14 ed. São Paulo: Editora Revista dos Tribunais, 2012, p. 99, SHIMURA, Sérgio. Título executivo. 2 ed. São Paulo: Método, 2005, p. 24; GRECO, Leonardo. O processo de execução: volume I. Rio de Janeiro: Renovar, 1999, p. 158

${ }^{22}$ DINAMARCO, Cândido Rangel. Instituições de Direito Processual Civil - Volume IV. 3 ed. São Paulo: Malheiros, 2009, p. 34.

${ }^{23}$ LIEBMAN, Enrico Tullio. Processo de execução. 5 ed. São Paulo: Saraiva, 1986, p. 4.

${ }^{24}$ Ibidem, p. 5. 
Na mesma esteira, também afasta do conceito de execução a execução indireta - em que são aplicadas medidas de coação, a pressionar psicologicamente o devedor para que pague o débito ${ }^{25}$ - por considerar que, ao contar com a colaboração do devedor, falta-lhe elemento essencial do conceito ${ }^{26}$.

O entendimento de Liebman ainda encontra adeptos na doutrina nacional, casos de Leonardo Greco $^{27}$ e Humberto Theodoro Junior ${ }^{28}$. A despeito disso, tal corrente, hoje, é minoritária.

Prevalece, dentre os doutrinadores brasileiros, uma segunda corrente, encabeçada pelo próprio Cândido Rangel Dinamarco que, numa definição mais restrita do que aquela primeira, conceitua execução como "o conjunto de medidas com as quais o juiz produz ou propicia a satisfação do direito de uma pessoa à custa do patrimônio de outra, quer com concurso da vontade desta, quer independentemente ou mesmo contra ela" 29 .

Nesta acepção, em que já exclui o cumprimento espontâneo da obrigação pelo devedor - já que as medidas executivas devem ser produzidas pelo juiz -, o autor considera execução apenas as modalidades de execução forçada. Assim definindo, aproxima-se do entendimento de Giuseppe Chiovenda ${ }^{30}$, e inclui no senso de execução tanto os meios de

\footnotetext{
${ }^{25}$ José Eduardo Carreira Alvim ressalta a prevalência das sanções cominatórias como principal meio de atuação sobre a vontade do executado. A partir da doutrina de Luis Ramon Madozzo, elenca como características destas medidas de coação a discricionariedade, a provisoriedade, a progressividade, a executividade, a excepcionalidade e a exegese restrita (Tutela específica das obrigações de fazer e não fazer na reforma processual. Belo Horizonte: Del Rey, 1997, p. 107-111). Todavia, consigne-se que ao juiz foi conferida ampla gama de faculdades e poderes destinados ao cumprimento dos provimentos, tais como como a ordem de busca a apreensão, remoção de pessoas e coisas e o desfazimento de obras (SILVA, Ovídio Araújo Baptista da. Execução obrigacional e mandamentalidade. Revista Páginas de Direito, Porto Alegre, ano 8, n⿳⺈ 773, 21 de maio de 2008. Disponível em <http://www.tex.pro.br/artigos/65-artigos-mai-2008/5951-execucaoobrigacional-e-mandamentalidade>. Acesso em 02 dez. 2015.).

${ }^{26}$ LIEBMAN, Enrico Tullio. Processo de execução. 5 ed. São Paulo: Saraiva, 1986, p. 6.

${ }^{27}$ GRECO, Leonardo. O processo de execução: volume I. Rio de Janeiro: Renovar, 1999, p. 161.

${ }^{28}$ THEODORO JÚNIOR, Humberto. Processo de execução e cumprimento de sentença. 25 ed. São Paulo: Livraria e Editora Universitária de Direito, 2008, p. 44.

${ }^{29}$ DINAMARCO, Cândido Rangel. Instituições de Direito Processual Civil - Volume IV. 3 ed. São Paulo: Malheiros, 2009, p. 32.

${ }^{30}$ CHIOVENDA, Giuseppe. Instituições de Direito Processual Civil. 4 ed. Campinas: Bookseller, 2009, p. 356.
} 
sub-rogação - a chamada execução direta, em que a vontade do devedor é substituída pela autoridade estatal e ela se encarrega conferir ao credor o seu direito ${ }^{31}$ - quanto os de coação - a chamada execução indireta, em que, como se disse, são impostas medidas de pressão psicológica no devedor para compeli-lo ao adimplemento.

Discorda dos adeptos de Liebman, portanto, no que concerne à execução indireta, já que, diferentemente do autor italiano, inclui esta espécie no conceito de execução. Justifica a divergência por considerar que estas medidas de coerção, assim como a execução por subrogação, importam no exercício imperativo do poder estatal, sacrificando a esfera jurídica do obrigado ${ }^{32}$.

Entendimento quase idêntico encontra-se expresso na obra de Luiz Rodrigues Wambier e Eduardo Talamini. Para os autores, no cumprimento espontâneo da obrigação não incide sanção negativa sobre o devedor - imposição de uma desvantagem, um mal para o transgressor de uma norma - característica marcante da execução. Diante disso, inexistindo transgressão a ser sancionada, não haveria de se falar em execução ${ }^{33}$.

Já quanto à execução indireta, entendem que há atuação de sanção intimidatória, o que impulsiona atuação voluntária do executado, mas não espontânea, uma vez que age coagido. Neste contexto, havendo atuação de sanção imposta pelo poder Estatal, nada elidiria o caráter executivo de tais medidas ${ }^{34}$.

Assim, para os autores, execução seria, tão-somente, aquilo que Cândido Rangel Dinamarco define como execução forçada, quais sejam, a execução por sub-rogação e a execução indireta. Neste mesmo sentido, Sérgio Shimura ${ }^{35}$, Marcus Vinicius Rios

${ }^{31}$ GAIO JR., Antônio Pereira. Tutela específica das obrigações de fazer. Rio de Janeiro: Forense, 2000, p. 56; LUISO, Francesco P. Diritto processuale civile - Il processo executivo. 7 ed. Milão: Giuffrè Editore, 2013, p. 9.

32 DINAMARCO, Cândido Rangel. Instituições de Direito Processual Civil - Volume IV. 3 ed. São Paulo: Malheiros, 2009, p. 35.

${ }^{33}$ WAMBIER, Luiz Rodrigues; TALAMINI, Eduardo. Curso avançado de Processo Civil - Volume 2. 13 ed. São Paulo: Editora Revista dos Tribunais, 2013, p. 44.

${ }^{34}$ Ibidem, p. 47.

${ }^{35}$ SHIMURA, Sérgio. Título executivo. 2 ed. São Paulo: Método, 2005, p. 25. 
Gonçalves $^{36}$, Marcelo Abelha ${ }^{37}$, Alexandre Freitas Câmara ${ }^{38}$, Luiz Guilherme Marinoni e Sérgio Cruz Arenhart ${ }^{39}$, entre outros.

Para o propósito deste trabalho, esta segunda definição é a que melhor se aplica. Isto porque a abordagem da desjudicialização da execução presume um contraste, justamente, entre modelos de processo executivo. A análise da desjudicialização é, pois, fenômeno afeto ao processo executivo e, como tal, contempla institutos a ele vinculados.

Por este motivo é que não se considerará, aqui, o cumprimento espontâneo da obrigação, uma vez que pouco ou nada difere do adimplemento estudado no direito material, podendo ser realizado a qualquer tempo e independentemente de um processo em curso. Aliás, o adimplemento voluntário é marcado por, justamente, dispensar um processo executivo $^{40}$.

Diferentemente - e ainda em consonância com a segunda definição de execução apresentada acima - se passa com a execução indireta, motivo pelo qual descabe apartá-la da noção de execução aqui considerada. Isto porque, mesmo as medidas de coerção que a constituem, se conformam em imposições do Estado ao particular, postura que exige um devido processo legal, ao qual, hoje, a execução indireta encontra-se devidamente incorporada e consolidada.

Logo, a execução tratada aqui neste trabalho, é, justamente, o procedimento de execução forçada, em forma de processo autônomo ou fase executiva, ou seja, os atos integrantes de procedimentos executivos por imposição do Estado-juiz, quer seja pela substituição da vontade do devedor - sub-rogação -, quer seja pressionando-o

${ }^{36}$ RIOS GONÇALVES, Marcus Vinicius. Novo curso de direito processual civil - Volume 3. São Paulo: Saraiva, 2008, p. 3.

${ }^{37}$ ABELHA, Marcelo. Manual de execução civil. 2 ed. Rio de Janeiro: Forense Universitária, 2007, p. 26 e 29.

${ }^{38}$ CÂMARA, Alexandre. Lições de Direito Processual Civil - Volume II. 20 ed., Rio de Janeiro: Lumen Juris, 2012 , p. 149.

${ }^{39}$ MARINONI, Luiz Guilherme; ARENHART, Sérgio Cruz. Curso de Processo Civil - Volume 3. 2 ed. São Paulo: Editora Revista dos Tribunais, 2008, p. 70 e 71.

${ }^{40}$ VERKERK, Remme. Procedural fairness and compliance. In: VAN RHEE, C.H.; UZELAC, Alan (coord.). Enforcement and enforceability - tradition and reform. Antwerp, Oxford, Portland: Intersentia, 2010, p. 253. 
psicologicamente - execução indireta. E não só os atos executivos de conteúdo coercitivo ${ }^{41}$, mas também todos aqueles que, dentro de um processo ou fase executivos, contribuam para a efetivação do direito material ${ }^{42}$.

Delimita-se, com isso, que a discussão sobre desjudicialização, neste trabalho, não passará pela mudança de modelo jurisdicional, ou seja, não se enfrentará a possibilidade de se praticar execução por equivalentes jurisdicionais - como na autotutela, por exemplo. A ideia será avaliar a possibilidade de se praticar a execução fora do Poder Judiciário, mas em ainda em vias de heterocomposição, com as mesmas garantias essenciais estabelecidas no ordenamento.

Destaque-se, ainda, que além da exclusão já pontuada quanto ao cumprimento espontâneo da obrigação, a limitação conceitual supra impõe que não se considere execução, para efeitos de análise da desjudicialização executiva, os mecanismos de defesa do executado, tais como os embargos e a impugnação ao cumprimento de sentença, já que não buscam a efetivação de um direito material, mas sim o reconhecimento de um direito. Sem prejuízo, haverá abordagem do assunto, haja vista a necessidade de se conhecer como se oportuniza a defesa do executado no atual modelo executivo e, em contraste, como se dá em modelos com maior desjudicialização, ponderando-se acerca da afetação ao princípio do contraditório.

\footnotetext{
${ }^{41}$ Segundo Araken de Assis, atos executivos são classificados em atos de: constrição - como, por exemplo, a penhora -, de transformação - como na conversão de obrigação de fazer em perdas e danos -, de custódia caso do depósito de bem penhorado -, de dação - hipótese de entrega do dinheiro produzido por expropriação -, de transferência - como na arrematação - e de pressão - exemplificado na estipulação de astreintes (ASSIS, Araken. Manual da execução. 14 ed. São Paulo: Editora Revista dos Tribunais, 2012, p. 102).

${ }^{42}$ Em que pese não serem atos executivos propriamente ditos, serão considerados execução atos como a citação do devedor, expedição de alvarás e intimação das partes, pois, inevitavelmente realizados dentro de um processo ou fase executivos, interessam para a análise de suas conformações dentro do modelo de execução.
} 


\subsubsection{Modelos executivos}

Fixada a compreensão de execução, pode-se, finalmente, passar para a análise daquilo que se denominou, até aqui, de modelos executivos, ideia à qual se liga a noção de desjudicialização da execução, objeto do presente trabalho.

O critério de classificação dos modelos executivos leva em conta os agentes responsáveis pela direção, determinação e prática dos atos executivos. Tais agentes são apenas os terceiros que atuam institucionalmente na execução, dentro de parâmetros de imparcialidade e em vias de heterocomposição, excluídos, portanto, os atos das partes ${ }^{43}$.

Isto posto, cabe ressaltar que esta classificação dos diferentes modelos executivos assume variadas formas na doutrina. Eduardo Henrique de Oliveira Yoshikawa ${ }^{44}$, segue a classificação de Cândido Rangel Dinamarco. Este processualista, por sua vez, faz distinção entre modelos de execuções judiciais e extrajudiciais. Segundo ele, extrajudiciais seriam os procedimentos executivos conduzidos por pessoas ou órgãos estranhos ao Poder Judiciário, com a invasão do patrimônio de um sujeito e expropriação de bens, realizadas por quem não é juiz ${ }^{45}$. Judiciais, em sentido contrário, seriam as execuções realizadas por quem é juiz.

Álvaro Pérez Ragone segue caminho semelhante e encontra três modelos de execução: o judicial - em que o sujeito responsável pela execução é um juiz -, o desjudicializado - em que a execução é atribuída a oficiais autorizados pelo Estado que ou

\footnotetext{
${ }^{43}$ A denominação "terceiro", aqui, tem o propósito de afastar do conceito de desjudicialização a transferência de atos para as partes. Assim, não configura desjudicialização, por exemplo, a faculdade de a parte alienar por conta própria um bem penhorado, prevista na primeira parte do caput do artigo 685-C do Código de Processo Civil. A discriminação tem finalidade metodológica, haja vista que este tipo de transferência tem peculiaridades que distinguem sobremaneira a forma de enfrentamento dos temas sensíveis à questão, tal como o impacto do interesse da parte na lisura e controle do ato e a própria essência da imparcialidade como requisito do devido processo legal.

${ }^{44}$ YOSHIKAWA, Eduardo Henrique de Oliveira. Execução extrajudicial e devido processo legal. São Paulo: Atlas, 2010, p. 34.

${ }^{45}$ DINAMARCO, Cândido Rangel. Instituições de Direito Processual Civil - Volume IV. 3 ed. São Paulo: Malheiros, 2009, p. 65.
} 
exercem sua profissão livremente ou integram o quadro funcional do próprio poder judiciário - e misto - em que há oficiais de execução e juízes atuando conjuntamente ${ }^{46}$.

Tais classificações, em que pese não estarem equivocadas, contêm limitações que prejudicam a compreensão que aqui se pretende dar ao tema.

Deixa-se de utilizar a primeira delas por ser genérica na classificação das execuções realizadas fora do judiciário, incluindo num mesmo grupo de execuções extrajudiciais modelos que podem ser substancialmente diferentes - casos de uma execução a cargo da administração pública e outra a cargo de uma pessoa privada. Esta distinção será importante para avaliar a pertinência da desjudicialização no Brasil.

Quanto à segunda, afasta-se sua incidência por dificultar a classificação dos diversos modelos híbridos, em que, à semelhança do modelo brasileiro previsto no Código de Processo Civil, um juiz atua em conjunto com oficiais que o auxiliam. Aceita esta hipótese, dificilmente seria possível classificar um modelo com outra alcunha que não a de "misto", o que diminui sobremaneira a utilidade da classificação.

Assim, entende-se como mais adequada ao desenvolvimento do tema da desjudicialização, a ótica empregada por outro segmento doutrinário, encabeçado por Eduardo Paiva e Helena Cabrita, que identifica dois grandes modelos executivos: os de natureza pública e os de natureza privada.

\footnotetext{
${ }^{46}$ RAGONE, Álvaro Pérez. El modelo orgánico de la ejecución civil desjudicializada desde el punto de vista de Derecho Comparado. Mitos y realidades de la desjudicialización. Revista de Derecho de la Pontificia Universidad Católica de Valparaíso, 2012, $\mathrm{n}^{\circ}$ 38, p. 393-430, Disponível em <http://www.scielo.cl/scielo.php?script=sci_arttext\&pid=S0718-68512012000100010\&lng=es\&nrm=iso>. Acesso em 30 jun. 2014, p. 396-398.
} 
Nos modelos de natureza pública, a execução é confiada a agentes públicos ${ }^{47}$. Por "agentes públicos", há de se considerar a administração pública direta e indireta, bem como seus respectivos agentes políticos e servidores estatais ${ }^{48}$

Os modelos de natureza pública se subdividem em modelos de natureza judicial e modelos de natureza administrativa.

No modelo público de natureza judicial, os mencionados agentes públicos, encarregados da execução, são atrelados ao exercício de jurisdição realizado no âmbito do Poder Judiciário. Em outras palavras, tem-se um modelo executivo público, de natureza judicial, quando a execução é coordenada e praticada por membros e servidores integrantes do quadro funcional do Poder Judiciário, tais como juízes, escreventes, analistas e oficiais de justiça.

Trata-se de modelo muito comum, já que a efetivação de direitos implica na invasão do patrimônio do devedor, função originariamente atrelada à soberania do Estado e comumente exercida pelo Poder Judiciário. Como se verá oportunamente, prepondera em países como Itália, Espanha e Brasil.

Já no modelo público de natureza administrativa, a realização coercitiva do direito é confiada a agentes públicos que, contudo, não pertencem ao Poder Judiciário. Estes agentes, em geral, estão integrados ao Poder Executivo, enquadrados na estrutura da administração direta ou indireta.

\footnotetext{
${ }^{47}$ PAIVA, Eduardo; CABRITA, Helena. O processo executivo e o agente de execução. 3 ed. Coimbra: Coimbra Editora, 2013, p. 10.

48 Adota-se, aqui, como critério metodológico, a classificação de Celso Antônio Bandeira de Mello, que subdivide os agentes públicos em agentes políticos, servidores estatais e particulares em colaboração com a administração (Curso de Direito Administrativo. São Paulo: Malheiros, 2010, p. 238). Não se ignora a divergência suscitada a partir da classificação distinta empregada por Hely Lopes Meirelles, que subdivide os agentes públicos em agentes políticos, agentes administrativos, agentes honoríficos, agentes delegados e agentes credenciados (Direito administrativo brasileiro. 37 ed. São Paulo: Malheiros, 2011, p. 76). Contudo, como ainda não há consenso a este respeito no Direito Administrativo e considerando que o presente trabalho tem escopo processual civil, sendo ainda funcionais para seu desenvolvimento ambas as classificações, doravante será adotada, arbitrariamente, a primeira classificação.
} 
O modelo público de natureza administrativa é mais comum na cobrança de créditos do próprio Estado, em que pese se verificar, também, em alguns países, nos créditos de natureza civil. É este o modelo que prepondera na Suécia, Rússia e, em certa medida, Estados Unidos.

Além dos modelos executivos públicos, há também o modelo executivo de natureza privada. Neste, a execução é confiada pelo Estado a agentes privados, aqui compreendidos, por exclusão, todos os entes e pessoas não incluídos no modelo público, inclusive os ditos "agentes particulares em colaboração com a administração" 49 , já que, sendo a atividade executiva função intrínseca à soberania do Estado, seu exercício por particulares tende a se dar por delegação de funções, podendo ou não sofrer algum controle do Estado ${ }^{50}$. Sua utilização prepondera em países como França - nas execuções civis - e Portugal.

Umberto Bara Bresolin observa um quarto modelo executivo, que denomina modelo misto. Para o autor, há modelo misto quando coexistem agentes públicos e privados como responsáveis pela execução. Este modelo híbrido, segundo ele, se justificaria por conta de alterações supervenientes em legislações outrora uniformes. Ocorreria, no Brasil, no caso das execuções pecuniárias de créditos dotados de garantia imobiliária, em que, além da execução pública judicial, seria possível, por força do Decreto-Lei $n^{\circ} 70 / 66$ e da Lei $n^{\circ}$ 9514/97, a execução particular ${ }^{51}$.

Este entendimento, contudo, nos parece apenas parcialmente correto. Assiste razão ao autor quando identifica modelos executivos em que coexistem agentes públicos e privados. Assim se dá no atual modelo executivo previsto no Código de Processo Civil, em que, apesar de a execução ser concentrada no Poder Judiciário, com a atuação de juiz e servidores públicos judiciários em quase todos os atos, há, por exemplo, o dispositivo do

\footnotetext{
${ }^{49}$ MELLO, Celso Antônio Bandeira de. Curso de Direito Administrativo. São Paulo: Malheiros, 2010, p. 241242.

${ }^{50}$ PAIVA, Eduardo; CABRITA, Helena O processo executivo e o agente de execução. 3 ed. Coimbra: Coimbra Editora, 2013, p. 11.

${ }^{51}$ BRESOLIN, Humberto Bara. Execução extrajudicial imobiliária: aspectos práticos. São Paulo: Atlas, 2013, p. 47-48.
} 
artigo 689-A do Código de Processo Civil ${ }^{52}$, que permite, a cargo de empresa privada, a realização de leilões eletrônicos para alienação de bens do devedor.

Entretanto, não se pode confundir a existência de um modelo em que coexistem agentes de naturezas distintas - e, portanto, misto, na terminologia empregada -, com a coexistência de dois ou mais procedimentos executivos, cada qual adepto de um modelo executivo, servientes à mesma finalidade.

Seguindo-se o exemplo adotado pelo autor, se um crédito imobiliário for executado ordinariamente, perante o Poder Judiciário, será respeitado o modelo constatado em seu procedimento, com a aludida mescla de agentes públicos e privados. Contudo, é possível que se execute esse mesmo crédito imobiliário por via extrajudicial, cujo modelo, independente daquele previsto no Código de Processo Civil, poderá ou não contar com a mescla de agentes de diferentes naturezas ${ }^{53}$.

Feitas estas considerações, há ainda de se questionar, à similaridade do que se observou quanto à classificação empregada por Álvaro Pérez Ragone, a funcionalidade de se admitir uma classe de modelos mistos. Isto porque, assim como se dá no Código de Processo Civil brasileiro, diversos outros procedimentos executivos contam, em maior ou menor escala, com a coexistência de agentes públicos e privados atuando em seu mister.

Para ilustrar o que aqui se alega, cabe dizer que, em Portugal, coexistem, na execução, cada qual com sua função, agentes de execução, profissionais pertencentes à iniciativa privada, e juízes executivos, profissionais pertencentes ao Poder Judiciário públicos, portanto. Na França, situação similar: os huissier de justice são profissionais

52 A redação do artigo 689-A do Código de Processo Civil foi introduzida pela Lei nº 11382/2006 e giza que “O procedimento previsto nos arts. 686 a 689 poderá ser substituído, a requerimento do exequente, por alienação realizada por meio da rede mundial de computadores, com uso de páginas virtuais criadas pelos Tribunais ou por entidades públicas ou privadas em convênio com eles firmado". No Tribunal de Justiça do Estado de São Paulo, o leilão eletrônico foi regulamentado pelo Provimento $\mathrm{n}^{\circ}$ 1625/2009, editado pelo Conselho Superior da Magistratura.

$53 \mathrm{O}$ estudo das modalidades executivas desjudicializadas de crédito imobiliário será feito a seu tempo, no segundo capítulo deste trabalho. 
liberais que coexistem com os juge de l'exécution, profissionais públicos judiciais. $\mathrm{Na}$ Espanha, em que pese a execução tramitar dentro do judiciário, a cargo do juiz e de um Secretario judicial, é possível, pelos ditames do artigo 641 da Ley de enjuiciamiento civil $^{54}$, que a venda do bem penhorado seja confiada a empresa privada, especializada.

Diante de tal contexto, em que frequentemente inexiste um apego a um modelo puro de execução, a se admitir um modelo misto como excludente das modalidades pública judicializada, pública desjudicializada e privada, estar-se-ia inutilizando uma classificação que tem grande utilidade para o estudo do processo executivo e suas diferentes conformações. Por outro lado, a existência dessa mescla é empiricamente constatada, não se podendo ignorá-la ao classificar o modelo executivo adotado num dado procedimento.

Assim, a proposta, aqui, é que a classificação se dê conforme a preponderância ${ }^{55}$ do modelo analisado, reservando-se a denominação de "modelo misto" nos estritos casos em que não for possível se identificar com clareza a prevalência de atuação de pessoas públicas ou privadas.

A execução prevista no Código de Processo Civil brasileiro, por exemplo, em que pese prever a mencionada possibilidade de alienação de bem do devedor por agente particular, tem ampla preponderância do modelo público judicializado: do primeiro ao último ato do procedimento executivo há constante e indispensável participação do juiz e de seus auxiliares ${ }^{56}$. Diferentemente se dá no modelo português, em que, como se verá com mais detalhes no segundo capítulo, a atuação do Poder Judiciário é mínima e pontual, preponderando um modelo executivo privado.

\footnotetext{
${ }^{54}$ Lei $\mathrm{n}^{\circ} 1$, de 7 de janeiro de 2000, reformada pela Lei $\mathrm{n}^{\circ} 13$, de 3 de novembro de 2009.

${ }^{55}$ A noção de preponderância já é antiga na ciência processual, sendo usada, por exemplo, por Pontes de Miranda, para fins de classificação da ação executiva do Código de Processo Civil de 1939, que congregava conhecimento e execução (MOREIRA, Alberto Camiña. Defesa sem embargos do executado: exceção de préexecutividade. 2 ed. São Paulo: Saraiva, 2000, p. 8).

${ }^{56}$ É o que se extrai, inclusive, da literalidade do artigo 577 do Código de Processo Civil, ao disciplinar que "não dispondo a lei de modo diverso, o juiz determinará os atos executivos e os oficiais de justiça os cumprirão".
} 


\subsubsection{Desjudicialização da execução}

Definidos aquilo que se entende por execução, bem como os modelos executivos possíveis, a compreensão do que se tratará como "desjudicialização da execução" é consequencial.

Em sentido amplo, desjudicialização da execução pode ser conceituada como a concentração de atos do procedimento executivo sob responsabilidade de terceiros externos ao Poder Judiciário. Uma vez desjudicializados, os atos passarão a ser ou típicos de um modelo público administrativo - desjudicialização pública administrativa - ou típicos de um modelo privado - desjudicialização privada ${ }^{57}$.

Isto posto, três ressalvas se fazem necessárias. Primeiramente, o conceito empregado faz ligeira distinção da acepção mais comum para "desjudicialização da execução", que a trata como uma redução da intervenção do juiz nos atos processuais ${ }^{58}$. Isto porque o recorte metodológico proposto é o da desjudicialização como técnica extrajudicial de aceleração do

\footnotetext{
${ }^{57}$ Registre-se que a precisa definição do conceito frequentemente não é objeto de grande preocupação da doutrina, de modo que o tratamento do tema acaba se dando de formas diversas conforme o estudo. Diante disso, se optou por desenvolver um conceito que permita uma classificação uniforme de acordo com o procedimento. Em que pese ter predefinições próprias, o conceito aqui adotado se aproxima daquele trazido Joel Dias Figueira Júnior, para quem desjudicialização consiste em "todas as maneiras de delegação ou retirada de atribuições, competências, atos inclusive de natureza decisória e até mesmo uma parcela da jurisdição (v.g., arbitragem) do Estado-juiz para as serventias extrajudiciais, órgãos ou organismos paraestatais, entidades particulares ou para o privado, como se verifica, por exemplo, no caso da arbitragem" (Execução simplificada e a desjudicialização do processo civil. In: ALVIM NETTO, José Manoel de Arruda; et al (coord.). Execução civil e temas afins do CPC/1973 ao Novo CPC: estudos em homenagem ao professor Araken de Assis. São Paulo: Editora Revista dos Tribunais, 2014, p. 579) ou mesmo da acepção sucinta de João Alberto de Almeida, para quem desjudicialização consiste na "descentralização de parte das atividades jurisdicionais, ou seja, que setores da sociedade pudessem voltar a contribuir com a administração da Justiça, praticando atos que anteriormente eram reservados apenas aos Órgãos Judiciários, por meio de seus Juízes e auxiliares diretamente a eles ligados" (Desjudicialização: a relação entre a arbitragem e os serviços notariais e registrais. Revista da Faculdade de Direito da Universidade Federal de Minas Gerais, Belo Horizonte, v. 59, junho-dezembro 2011, p. 103).

${ }^{58}$ LEBRE DE FREITAS, José. A ação executiva à luz do Código de Processo Civil de 2013. 6 ed. Coimbra: Coimbra Editora, 2014, p. 24; GARSON, Samy. A desjudicialização da execução hipotecária como meio alternativo de recuperação de créditos. 156 f. Dissertação (Mestrado em Ciências Jurídico-Processuais) Faculdade de Direito, Universidade de Coimbra, Coimbra, 2006, p. 110.
} 
processo $^{59}$, ou seja, como mecanismo para afastar a execução do Poder Judiciário como um todo, e não apenas do juiz.

Assim, não nos interessa, por exemplo, a delegação de atos do juiz para os escreventes de seu próprio cartório ${ }^{60}$, mas sim a dispensa dessa estrutura do Judiciário na realização da execução. Traçando um paralelo com a doutrina administrativista, pode-se dizer que o tratamento aqui empregado para desjudicialização da execução é analisa-la não como meio de desconcentração - deslocamento de atividades na intimidade de uma mesma pessoa em liame de hierarquia - mas sim como meio de descentralização - transferência de atividade para pessoa diversa, no caso, dissociada no Poder Judiciário, em liame, no máximo, de controle ${ }^{61}$.

A segunda ressalva é que há de se distinguir a desjudicialização incidental, de apenas alguns atos do procedimento, com a desjudicialização do procedimento em si, como um todo. Explica-se.

A constatação e classificação de um procedimento executivo se dá por meio de uma análise geral, não de alguns, mas de todos os atos deste procedimento, de modo a identificar qual modelo executivo prevalece de acordo com os agentes responsáveis pela prática da maior parte dos atos - e aqui se rememora a noção de preponderância do tópico anterior.

Essa apuração do modelo executivo do procedimento como um todo se baseia em um critério puramente quantitativo, que volta atenção aos atos procedimentais. Desse modo, pode-se classificar, por exemplo, como preponderantemente privada uma execução

\footnotetext{
${ }^{59}$ Sobre as diferentes técnicas de aceleração do processo, v. Introdução.

60 Prática encontrada na doutrina pela alcunha de "desjurisdicionalização" (POMAR, João Moreno. Desjudicialização e Desjurisdicionalização. Âmbito Jurídico, Rio Grande, XI, n. 54, jun 2008. Disponível em: <http://www.ambito-juridico.com.br/site/index.php?n_link=revista_artigos_leitura\&artigo_id=2814>. Acesso em 15 abr. 2014). O termo, contudo, é polissêmico, sendo designado também como a criação de instrumentos não jurisdicionais de composição de conflitos (ROCHA, Joaquim Freitas da apud RODRIGUES, Luísa Maria. Processo Executivo: da execução fiscal - desjurisdicionalização. $61 \mathrm{f}$. Dissertação (Mestrado em Ciências Jurídico-Económicas) -Faculdade de Direito, Universidade do Porto, Porto, 2011, p. 24).

${ }^{61}$ A partir dos conceitos de Celso Antônio Bandeira de Mello (Curso de Direito Administrativo. São Paulo: Malheiros, 2010, p. 147).
} 
coordenada por um juiz, porém com todos os demais atos a cargo de agentes privados, ou como preponderantemente pública judicial uma execução coordenada por um agente de execução privado, porém com todos os demais atos a cargo dos servidores de um cartório judicial $^{62}$.

Justifica-se o critério pelo fato de a desjudicialização se apresentar como possível solução, justamente, a um problema quantitativo, qual seja, o grande número de processos executivos e de atos necessários para condução destes processos que tem consumido recursos e tempo do Poder Judiciário. Em outras palavras, o que se busca com a desjudicialização é, justamente, reduzir a quantidade de atos do procedimento executivo que hoje recaem sobre a estrutura do Poder Judiciário, cujo volume vem prejudicando o curso destas e todas as demais demandas.

Para este fim, o critério quantitativo, em que pese não se afigurar como método totalmente preciso de aferição, é suficiente para que se identifique qual modelo executivo prepondera em um determinado procedimento, o que basta para o desenvolvimento deste trabalho e que pode ser útil, inclusive, para a classificação e o escalonamento da execução em critérios estatísticos.

Logo, a desjudicialização de um ou mais atos de um determinado procedimento, em que pese alterar o modelo executivo atinente a estes atos, não necessariamente conforma a

\footnotetext{
${ }^{62}$ Com isso, entende-se como prescindível a distinção feita por Umberto Bara Bresolin entre desjudicialização executiva - redução, em maior ou menor grau, mas sem completa dispensa, da participação do juiz no desempenho dos atos tendentes à satisfação do exequente - e execução extrajudicial - em que a participação do juiz é apenas eventual, havendo afastamento potencialmente total do juiz (Execução extrajudicial imobiliária: aspectos práticos. São Paulo: Atlas, 2013, p. 53 e 67). Pelo critério aqui adotado, a qualidade do agente encarregado da execução - se membro ou servidor - é irrelevante, já que a desjudicialização visa solucionar um problema de toda a estrutura do Poder Judiciário e não apenas de seus agentes. Um Judiciário que tem dificuldades em cumprir seus atos de expediente, como expedição de ofícios, mandados e publicações, a cargo de servidores, é tão ineficiente quanto um Judiciário que represa os atos decisórios, a cargo de juízes. Logo, na compreensão aqui adotada, aquilo que o autor entende como execução extrajudicial nada mais é que um procedimento em que houve desjudicialização "potencialmente total" dos atos que incumbiriam ao juiz.
} 
desjudicialização do procedimento em si, uma vez que, para tanto, é necessário que a maioria dos atos seja típica do modelo público administrativo ou do modelo privado.

A terceira ressalva é que o termo desjudicialização da execução pode ser tratado sob um enfoque mais estrito do que aquele primeiro.

Isto porque, a rigor, nem todo ato de procedimento executivo típico de um modelo privado ou público administrativo sofreu um processo de desjudicialização. Em outras palavras, é possível que a responsabilidade pela prática de um determinado ato nunca tenha recaído sobre o Poder Judiciário - judicialização -, não havendo sentido, por isso, de se falar em desjudicialização ${ }^{63}$.

Logo, em sentido estrito, pode-se conceber a desjudicialização da execução como um processo pelo qual a responsabilidade pela prática de um ou mais atos do procedimento executivo é transferida de agentes integrantes do Poder Judiciário para agentes públicos pertencentes a outros Poderes - geralmente o Executivo - ou para agentes privados.

A despeito disso, para fins deste trabalho, o termo "desjudicialização da execução" será utilizado, ordinariamente, na acepção ampla, suficiente para a maior parte da exposição e consonante com o tratamento dado pela doutrina específica sobre o tema. Quando se fizer necessária a especificação, a acepção estrita será expressamente destacada.

Feitas estas considerações, passemos, agora, a estudar os modelos executivos passados, presentes e futuros adotados pela principal legislação brasileira de cada época.

\subsection{Breve histórico da execução brasileira por quantia}

Neste tópico, a análise voltará atenção a alguns aspectos dos principais procedimentos ao longo da história da execução no Brasil, a fim de contextualizar o tema e

\footnotetext{
${ }^{63}$ Tal fato, porém, não impede que este ato seja computado como tipicamente privado ou público administrativo para efeitos de quantificação e definição do modelo executivo empregado.
} 
o modelo executivo atualmente empregado no país, verificando-se, ainda, eventual experiência de desjudicialização pretérita.

Para tanto, é necessário, primeiramente, esclarecer que a abordagem, neste tópico, terá foco dogmático, sem maiores aprofundamentos na apuração histórica dos motivos e interpretações da legislação posta em cada lapso temporal. Isto porque, em que pese não poder ignorar a história do Direito, o trabalho não tem tal foco retrospectivo - o que demandaria pesquisa exaustiva e, portanto, dedicada -, mas sim prospectivo, voltado à projeção de um novo modelo executivo no atual contexto do Processo Civil.

A ideia, assim, é de apenas identificar o principal modelo executivo brasileiro de cada época e, em cada um, localizar possíveis posturas de deslocamento da atividade do judiciário para terceiros, públicos ou privados.

\subsubsection{As Ordenações Filipinas}

O primeiro modelo veio juntamente com a independência do Brasil. No estado recém-criado, houve a incorporação da legislação então vigente em Portugal ${ }^{64}$, qual seja, as Ordenações Filipinas ${ }^{65}$.

Em que pese a distância no tempo e no desenvolvimento do direito dificultarem a aferição, nos moldes hoje concebidos, de qual o modelo executivo empregado - tais como sua localização dentro da estrutura de poder estatal, a forma de investidura e remuneração dos profissionais envolvidos, a natureza jurídica dos atos praticados e como se exercia

\footnotetext{
${ }^{64}$ LUCON, Paulo Henrique dos Santos. Embargos à execução. São Paulo: Saraiva, 1996, p. 66.

65 Indisponível no acervo on line de legislação do Planalto, as menções feitas neste capítulo às Ordenações Filipinas decorrem de consulta feita junto ao sítio da Universidade de Coimbra, que digitalizou e disponibilizou parte da obra de Cândido Mendes de Almeida, Codigo Philippino, ou, Ordenações e leis do Reino de Portugal: recopiladas por mandado d'El-Rey D. Philippe I. Rio de Janeiro: Typ. do Instituto Philomathico, 1870. Disponível em <http://www1.ci.uc.pt/ihti/proj/filipinas/ordenacoes.htm>, Acesso em 20 mar. 2015.
} 
controle da atividade ${ }^{66}$-, é notável que todo o processo contava, no âmbito processual, com intensa atuação do Estado.

Logo, não é equívoco se afirmar que nas Ordenações Filipinas a execução de créditos civis, em geral, era iniciada, conduzida e encerrada por juízes ${ }^{67}$, o que denota um modelo preponderantemente público judicializado. Este controle da execução exercido pelo juiz já se aplicava inclusive às execuções de títulos obtidos a partir de arbitragem, tal como previsto no Livro III, Título XVI, $\S 2$ das Ordenações Filipinas ${ }^{68}$.

Dessa forma, a execução, em regra, seguia o rito então previsto no Título LXXXVI do Livro III. O dispositivo previa que o executado, com alguma variação procedimental a depender de sua localização em comparação com a sede da execução, era requerido a pagar ou oferecer bens à penhora ${ }^{69}$.

${ }^{66}$ Paulo Henrique dos Santos Lucon observa que, pelo fato de se tratar de mera atualização das Ordenações Manuelinas, as Ordenações Filipinas têm muitas disposições pouco claras (Embargos à execução. São Paulo: Saraiva, 1996, p. 62).

${ }^{67}$ DINAMARCO, Cândido Rangel. Execução civil. 8 ed. São Paulo: Malheiros, 2002, p. 70; LUCON, Paulo Henrique dos Santos. Perfil histórico da execução civil. No prelo, disponibilizado para aproveitamento da disciplina Tutela Jurisdicional Executiva do Curso de Pós-Graduação stricto sensu da USP, 2010, p. 75.

68 "E se cada huma das partes não apelar em tempo devido da sentença dada pelos árbitros, tal sentença se dará à execução pelos juízes ordinários [...], assi como se daria à execução, sendo dada pelos Juizes ordinários.”.

${ }^{69} \mathrm{O}$ caput do título LXXXVI do Livro Terceiro das Ordenações Filipinas prevê que "quando algumas sentenças da mór alçada, ou outra qualquer, que passar em cousa julgada, for apresentada a algum Julgador, pela qual se deva fazer execução, sendo o dito Julgador requerido para isso, a mandará com diligência executar; e sendo a condenação per aução pessoal, que descenda de contracto, ou quase-contracto, per que alguma parte seja condenada, que pague ao vencedor alguma quantidade de dinheiro, pão, vinho, azeite, ou qualquer outra cousa, que se costuma contar, pesar, ou medir, será o condenado requerido, que pague o conteúdo na sentença ou dê penhores bastantes à condenação, sendo achado no lugar, onde se faz a execução; e não sendo hí achado para ser requerido, seja citado na fôrma que dissemos no Título 1: Das citações; o qual requerimento lhe será dado, feitos pelo Tabellião, ou Scrivão, que fôr presente, ou pelo Porteiro, no caso, onde Porteiro abasta para á penhora, segundo se dirá no Título 89: Da execução, que se faz per o Porteiro; e será scripto pelo Scrivão, que os pregões houver de escrever, por fé do Porteiro, que o requerer. E feita a dita notificação e requerimento, não será necessário ser o condenado mais requerido ao tempo da venda e rematação dos penhores; e este requerimento se assentará nos autos da penhora pelo Scrivão, ou Tabellião, e não o assentando, incorra em pena de perdimento do Officio. E se logo não pagar o conteúdo na sentença, não lhe será mais dado tempo, sem spaço algum, antes será logo feita penhora em tantos de seus bens, que bastem para a dita condenação.”. 
Esta penhora das Ordenações Filipinas, prevista no Título LXXXIX do Livro III, se dava por ordem do juiz e poderia ser efetivada por três agentes, que atuavam em seu nome ${ }^{70}$, quais sejam, o "escrivão", o "porteiro" e o "tabellião", cabendo o encargo a cada um conforme, dentre outros requisitos, o valor do débito exequendo ${ }^{71}$.

Os "porteiros", ou, mais precisamente, "Porteiros dos Corregedores da Côrte e dos Desembargadores da Casa de Suplicação”, eram precursores dos atuais Oficiais de Justiça ${ }^{72}$. Atrelados ao Estado, atuavam apenas mediante determinações oficiais, consubstanciadas em alvarás e cartas seladas - semelhante ao que ocorre hoje com os mandados judiciais ${ }^{73}$.

O “escrivão", por sua vez, era profissional de variada utilidade nas Ordenações. Tal fato impede que se faça um paralelo perfeito entre sua função e a dos atuais escreventes de justiça. É fato, porém, que as atividades hoje atribuídas aos escreventes, à época, com as devidas equivalências, competiam aos "escrivães". Na penhora, cuidava dos trâmites burocráticos, tais como a notificação do devedor, anotação da penhora e designação de arrematação de bens eventualmente tomados pelo Porteiro. Era, também, atrelado ao Poder Público, não se podendo afirmar que sua atividade implicava em execução afastada do judiciário.

${ }^{70}$ LUCON, Paulo Henrique dos Santos. Perfil histórico da execução civil. No prelo, disponibilizado para aproveitamento da disciplina Tutela Jurisdicional Executiva do Curso de Pós-Graduação stricto sensu da USP, 2010 , p. 76.

${ }^{71} \mathrm{O}$ caput do título LXXXIX do Livro Terceiro das Ordenações Filipinas prevê que "Se a sentença de que se requer execução passar de quantia de mil reis, o Julgador a mandará executar per um Tabellião, ou Scrivão dante si, o qual levará consigo Porteiro para tomar os penhores; e o Scrivão requererá à parte condenada, que pague ou dê penhores, o screverá no auto penhora o requerimento, e per ele ficará logo requerido para arrematação, o cumprirá em tudo acerca da dita execução o que dissemos no título 86: Das execuções. E se a condenação não passar de mil reis, mandará fazer a penhora pelo Porteiro, sem mais Scrivão, o qual Porteiro levará o Alvará da condenação, e fará o dito requerimento à parte; e não querendo pagar, o penhorará e dará de todo fé ao Tabellião, ou Scrivão, que os pregões houver de screver, guardando acerca da dita penhora o que dissemos no Título 86: Das execuções...”.

72 CRUZ E TUCCI, José Rogério; AZEVEDO, Luiz Carlos de. Lições de história do processo civil lusitano. São Paulo: Editora Revista dos Tribunais, 2009, p.74.

${ }^{73} \mathrm{O}$ item 2 do Título XXI do Livro Primeiro das Ordenações Filipinas dispõe que "E das sentenças que forem baixadas pelos Corregedores, de quantia de mil réis pra baixo, fará o Porteiro as execução, levando Alvará assinado pelo Corregedor. E se forem de maior quantia, far-se-ão Cartas seladas, e não Alvarás...”. 
Finalmente, a figura que desperta maior interesse neste quadro é a do "tabellião", dada a associação imediata com os atuais tabeliães ${ }^{74}$, o que poderia induzir à constatação de uma desjudicialização dos atos de penhora das Ordenações Filipinas.

Porém, uma análise mais aprofundada revela que havia duas espécies de tabeliães previstos na legislação em comento: os "tabeliães das notas", previstos no título LXXVIII do Livro Primeiro, figura mais próxima dos tabeliães de hoje, encarregados de escrituras, basicamente, e remunerados pelas partes que acionassem seu serviço, e os "tabeliães do judicial", previstos no título LXXIX do Livro Primeiro, figura muito assemelhada aos escrivães supracitados, remunerados por salário pago pelo Estado e proibidos de auferirem quaisquer importâncias de outra sorte. Estes últimos, para efeitos de execução, eram os profissionais envolvidos nos atos de penhora.

Em que pese a penhora seguir o mesmo roteiro judicializado preponderante no procedimento, as Ordenações Filipinas já traziam as figuras do depositário e do administrador $^{75}$, auxiliares da justiça na condição de particulares em colaboração com a administração, encarregados do cuidado e administração dos bens penhorados quando não entregues diretamente à Justiça. Essa admissão do terceiro particular como depositário persiste em todos os diferentes momentos da legislação executiva brasileira ao longo da história, e, ressalvadas as dificuldades de classificação precisa já esclarecidas do início deste tópico, podem ser enquadradas como hipóteses de desjudicializações incidentais.

\footnotetext{
74 Dada essa mescla entre o público - prestação de serviço público financiado por taxas recolhidas pelos usuários e cargo público com investidura mediante concurso público - e o privado - liberdade para organizar sua atividade nos moldes da iniciativa privada - a doutrina convencionou enquadrar os tabeliães dentre os "particulares em colaboração com a administração" (MELLO, Celso Antonio Bandeira de. Curso de Direito Administrativo. São Paulo: Malheiros, 2010, p. 242) ou "agentes delegados" (MEIRELLES, Hely Lopes. Direito administrativo brasileiro. 37 ed. São Paulo: Malheiros, 2011, p. 81), que, como visto, para efeitos de desjudicialização, são tratados como agentes privados.

75 O item 1 do Título LXXXVI do Terceiro Livro das Ordenações Filipinas prevê que os bens entregues à penhorados sejam "entregues às Justiças, que houverem de fazer a execução, ou à pessoa, a que as taes Justiças os mandarem entregar, de maneira que o condenado, nem per si, nem per outrem, fique per via alguma em posse dos penhores. E dando à penhora bens de raiz livres e desembargados, será desapossado deles, e serão entregues por autoridade de Justiça a pessoa ou pessôas sem suspeita, seguras e abonadas, a que será mandado que os não entreguem, nem rendimento algum deles ao condenado.”.
} 
A expropriação dos bens penhorados era realizada por meio de pregões em praça pública, os quais eram conduzidos pelos já citados "tabelliães do judicial”, escrivães e, principalmente, os “porteiros", todos agentes públicos judiciais ${ }^{76}$.

A defesa do executado, regulamentada no título LXXXVII do Livro Terceiro, se dava por meio de embargos, ajuizados em até seis dias após a penhora e processados em autos apartados, porém direcionados ao juiz da execução.

Logo, a análise das Ordenações Filipinas revela um modelo notadamente público judicializado. A atuação do juiz prevalece na coordenação e condução do procedimento e seus auxiliares são preponderantemente atrelados à estrutura do Poder Judiciário. Ainda assim, já figuram particulares atuando como depositários e administradores dos bens penhorados, caracterizando-se, assim, desjudicialização particular incidental, incapaz, por si só, de alterar o modelo procedimental empregado, mas suficiente para evidenciar que a execução, desde seu princípio no Brasil, já conta com a interação com outros agentes que não aqueles pertencentes à estrutura do judiciário.

\subsubsection{O Regulamento $n^{\circ} 737 / 1850$}

Em razão de grande insatisfação com o excessivo detalhamento do processo $^{77}$, a legislação portuguesa foi gradativamente removida, a iniciar pelo Regulamento $\mathrm{n}^{\circ} 737$, de 1850, que fixou regras processuais para causas comerciais, estendido para as execuções civis pelo Decreto 3.272, de 1885, e para as execuções sobre ações reais, coisa certa ou em espécie pelo Decreto 763 , de $1890^{78}$.

\footnotetext{
${ }^{76}$ Segundo o item 26 do Título LXXXVI do Terceiro Livro das Ordenações Filipinas, os bens penhorados “[...] andarão em pregão pelas praças e lugares públicos da Cidade, ou Villa, onde se a execução e arrematação houver de fazer. E o Tabellião, ou Scrivão, será presente cada dia ao pregão, que o Porteiro der no lugar mais principal, e os outros pregões screverá o Porteiro, que os der, nos autos da execução".

${ }^{77}$ LUCON, Paulo Henrique dos Santos. Eficácia das decisões e execução provisória. São Paulo: Editora Revista dos Tribunais, 2000, p. 53.

${ }^{78}$ GRECO, Leonardo. O processo de execução: volume I. Rio de Janeiro: Renovar, 1999, p. 38.
} 
A partir da nova legislação, as execuções persecutórias de quantia passaram a ser movidas não só em função de sentença, como ocorria nas Ordenações Filipinas, mas também por títulos extrajudiciais ${ }^{79}$, sendo estas veiculadas por meio de ação executiva - em que havia processo de conhecimento sumário prévio aos atos executivos - e aquelas promovidas por meio de execução de sentença - em que havia execução, apenas ${ }^{80}$.

No que concerne aos agentes incumbidos da atividade, a exemplo do que ocorria nas Ordenações Filipinas, os atos executivos foram mantidos como atividade estatal ${ }^{81}$, sob coordenação e atuação do juiz da causa principal, do início ao fim ${ }^{8283}$. Também aqui, a exemplo do que previam as Ordenações Filipinas, a execução dos títulos obtidos por decisão arbitral era feita perante um juiz, "sob o duplo fundamento da execução ser uma prerrogativa do juízo ordinário e de, pela sentença, extinguir-se a funcção cometida aos árbitros" ${ }^{\text {" }}$.

Os atos de penhora e avaliação passaram a ser realizados por oficiais de justiça ${ }^{85}$, profissionais públicos pertencentes ao Poder Judiciário - condição mantida até os dias atuais ${ }^{86}$, assim como mantido está seu papel central nos atos de constrição. Assim como

79 DINAMARCO, Cândido Rangel. Execução civil. 8 ed. São Paulo: Malheiros, p. 83. Nas Ordenações Filipinas, as dívidas contraídas por escritura pública, alvarás particulares de pessoas privilegiadas e dotes eram executadas por meio da ação de assinação de dez dias, procedimento sincrético, similar à ação monitória (GRECO, Leonardo. A execução e a efetividade do processo. Revista de processo, São Paulo, ano 24, vol. 94, abr-jun. 1999, p. 37).

${ }^{80}$ LUCON, Paulo Henrique dos Santos. Embargos à execução. São Paulo: Saraiva, 1996, p.68.

${ }^{81}$ DINAMARCO, Cândido Rangel. Execução civil. 8 ed. São Paulo: Malheiros, p.74.

${ }^{82}$ FRAGA, Affonso. Theoria e pratica na execução das sentenças. São Paulo: C. Teixeira \& C. Editores, 1922, p. 152.

${ }^{83} \mathrm{O}$ artigo 490 do Regulamento 737 de 1850 disciplina que "É competente para a execução: $\S 1^{\circ} \mathrm{O}$ juiz da causa principal ou aquelle que o succeder".

${ }^{84}$ FRAGA, Affonso. Theoria e pratica na execução das sentenças. São Paulo: C. Teixeira \& C. Editores, 1922, p. 155.

85 GRECO, Leonardo O processo de execução: volume I. Rio de Janeiro: Renovar, 1999, p. 42; FRAGA, Affonso. Theoria e pratica na execução das sentenças. São Paulo: C. Teixeira \& C. Editores, 1922, p. 175.

${ }^{86}$ Como observa Cândido Rangel Dinamarco, nunca houve, no Brasil, oficiais de justiça ligados ao Poder Executivo (Execução civil. 8 ed. São Paulo: Malheiros,, p. 82). 
ocorria com os porteiros das Ordenações, também os oficiais atuavam mediante ordem do juiz $^{87}$.

Persistia a desjudicialização do depositário, ou seja, atuação de terceiro, particular, na condição de depositário dos bens penhorados, abrindo-se aqui a possibilidade de o próprio devedor exercer esta função ${ }^{88}$.

A alienação dos bens penhorados também era judicial, ainda feita por meio de praça pública $^{89}$, com apoio dos serventuários da justiça ${ }^{90}$, porém agora com expressa previsão da necessidade de coordenação e presidência de um juiz ${ }^{91}$.

A defesa do executado, nos termos dos artigos 575 a 595 do Regulamento 737, seguia sendo feita por meio de embargos, direcionados ao juiz do processo de conhecimento, no prazo de seis dias após a penhora ou logo após a arrematação, porém antes da assinatura da carta de arrematação ou adjudicação ${ }^{92}$.

Logo, com algumas poucas alterações processuais, permaneceu a execução em modelo preponderantemente público judicializado, em moldes muito similares aos das Ordenações Filipinas.

${ }^{87}$ FRAGA, Affonso. Theoria e pratica na execução das sentenças. São Paulo: C. Teixeira \& C. Editores, 1922, p. 173.

${ }^{88}$ ALMEIDA E OLIVEIRA, Antonio. A Lei das Execuções ou Consolidação e concordancia das disposições, que, segundo a Lei $n .3272$ de 5 de outubro de 1885 e o Regulamento n. 9549 de 23 de janeiro de 1886, regem as acções hypothecaria e de penhor agrícola e as execuções commerciaes e civis em geral. Rio de Janeiro: B.L. Garnier, 1887, p. 99.

${ }^{89}$ FRAGA, Affonso. Theoria e pratica na execução das sentenças. São Paulo: C. Teixeira \& C. Editores, 1922, p. 216.

${ }^{90}$ Conforme o artigo 548 do Regulamento 737 de 1850, “A arrematação será feita no dia e logar annunciados, publicamente, presentes o Juiz, Escrivão e Porteiro; e expostos os objectos que devem ser arrematados, ou as amostras sendo possivel.".

${ }^{91}$ Disciplina o Regulamento 737 de 1850, em seu art. 673 que "[...] 13º. A arrematação em dia e logar anunciados, com publicidade, presidida pelo Juiz..."

${ }^{92}$ LUCON, Paulo Henrique dos Santos. Embargos à execução. São Paulo: Saraiva, 1996, p.70. 


\subsubsection{Os Códigos Estaduais e Código de Processo Civil de 1939}

Posteriormente, houve uma pluralização de legislações processuais, a chamada fase dos Códigos Estaduais, promulgados entre 1905 e 1930 em alguns Estados ${ }^{93}$. Dado o foco o trabalho, descabe, aqui, uma análise pormenorizada dos diversos regramentos da época. Em linhas gerais, como assevera Cândido Rangel Dinamarco, pode-se dizer que não houve grandes modificações no regramento já vigente, senão uma sistematização da ação executiva, com indicação dos diferentes títulos que poderiam ensejá-la ${ }^{94}$, de modo que tampouco o modelo executivo dos procedimentos foi alterado.

A unidade legislativa retornou com o Decreto-Lei $\mathrm{n}^{\circ}$ 1608, de 1939, o primeiro Código de Processo Civil nacional ${ }^{95}$, cujo oitavo livro era inteiramente dedicado à execução. Neste diploma, houve a solidificação da dualidade entre ação executiva ou processo executivo e processo de execução ou processo executório. A ação executiva - ou processo executivo - era dedicada a títulos extrajudiciais e consistia em um processo sincrético $^{96}$, com uma fase inicial de conhecimento, com penhora incidente, contraditório e prática de atos expropriatórios apenas após sentença; já o processo de execução - ou processo executório partia de sentença condenatória ou outros títulos judiciais taxativamente elencados ${ }^{97}$, limitada a cognição à análise de pressupostos processuais e regras procedimentais, bem como de eventual oposição de embargos à execução ${ }^{98}$.

Em qualquer dos procedimentos, a execução civil por quantia seguiu sob a condução e coordenação de um juiz, auxiliado principalmente por servidores do Poder Judiciário, do

\footnotetext{
${ }^{93}$ Nos Estados em que não houve promulgação de um Código de Processo Civil permaneceu em vigência a legislação anterior (LUCON, Paulo Henrique dos Santos. Embargos à execução. São Paulo: Saraiva, 1996, p.76).

94 DINAMARCO, Cândido Rangel. Execução civil. 8 ed. São Paulo: Malheiros, p. 78.

${ }^{95}$ Ibidem, p. 79.

96 Ibidem, p. 81.

${ }^{97}$ Para rol de demais títulos judiciais v. DINAMARCO, Cândido Rangel. Execução civil. 8 ed. São Paulo: Malheiros, p. 81; LUCON, Paulo Henrique dos Santos. Embargos à execução. São Paulo: Saraiva, 1996, p. 78.

${ }^{98}$ GRECO, Leonardo. O processo de execução: volume I. Rio de Janeiro: Renovar, 1999, p. 45 e 46.
} 
princípio ao final do processo, mantendo-se, inclusive, a responsabilidade do oficial de justiça pela penhora ${ }^{99}$.

A figura do depositário desjudicializado persistiu de modo similar ao empregado no Regulamento $\mathrm{n}^{\mathrm{o}}$ 737. Contemplava, em regra, o executado como fiel depositário. Havendo discordância do credor, o depositário seria alguma das instituições financeiras públicas, o depositário público - ambas desjudicialização pública administrativa - ou depositário particular-desjudicialização particular ${ }^{100}$.

Abriu-se a possibilidade de que a avaliação do bem penhorado fosse realizada por particular idôneo, nomeado pelo Juízo, sempre que não houvesse avaliador judicial disponível, a evidenciar nova desjudicialização particular incidental ${ }^{101}$.

A expropriação ainda se realizava por meio de praça pública, sob controle e presença do Juiz e seus auxiliares, em moldes muito similares aos do Regulamento anteriormente vigente $^{102}$.

Porém, uma vez infrutífera a praça, os bens poderiam ser alienados por iniciativa particular, a cargo de "leiloeiro público" ou "institutos autorizados em lei". Os leiloeiros são profissionais privados, regulamentados pelo Decreto $\mathrm{n}^{\circ} 21.981 / 32$, habilitados mediante

${ }^{99}$ Dispunha o artigo 928 daquele diploma legal que "os oficiais de justiça farão com que recaia a penhora em tantos bens quantos bastem para assegurar a execução, e, dentro de cinco (5) dias, contados do recebimento do mandado, efetuarão a diligência, lavrando o respectivo auto, sob pena de suspensão. ".

${ }^{100} \mathrm{O}$ artigo 945 do mencionado diploma previa que "se o exequente não convier em que fique como depositário o próprio executado, os bens penhorados depositar-se-ão da seguinte forma: I - No Banco do Brasil, na Caixa Econômica ou em Banco de que os Estados-membros da União possuam mais da metade do capital social integralizado, ou, à falta de tais estabelecimentos de crédito ou agências suas, no lugar, em qualquer estabelecimento de crédito, a critério do Juiz da causa, as quantias em dinheiro, as pedras e metais preciosos e os papéis de crédito; II - em mão do depositário público, os móveis, semoventes e imóveis, se ao juiz não parecer conveniente que fique como depositário n próprio executado; III - em mãos de depositário particular quando não haja, na séde do juízo, depósito público ou estabelecimento bancário.”.

${ }^{101}$ Conforme artigo 937 daquele Código, "se a penhora não fôr embargada ou forem rejeitados os embargos, ou se a ação executiva fôr julgada procedente, os bens serão avaliados pelo avaliador do juizo, mediante distribuição. À falta de avaliador judicial, o juiz nomeará pessoa idônea.”.

102 Conforme artigo 965, “a arrematação far-se-á em dia, hora e lugar anunciados, com a presença do juiz, do escrivão e do porteiro, expostos, se possível, os objetos que deverão ser arrematados. ”. 
matrícula nas Juntas Comerciais. Como sua existência perdura até os dias de hoje, com papel cada vez mais relevante na execução, será abordado no item seguinte.

Já os "institutos autorizados em lei" seriam, no entendimento de Amílcar de Castro $^{103}$, os corretores oficiais de fundos públicos ou de mercadorias - embrionários dos corretores de valores e mercadorias do sistema financeiro atual, tratava-se de profissão de iniciativa particular, controlada pelo Estado ${ }^{104}$-, a "Câmara Sindical dos Corretores" substituta da "Junta Comercial dos Corretores" estabelecida no Decreto n 648 de 1849, tinha como função coordenar e fiscalizar a atividade dos corretores supracitados - e os "Armazéns Gerais" - empresas privadas, regulamentadas pelo Decreto $\mathrm{n}^{\circ}$ 1.102/1903, com finalidade de guarda e conservação de mercadorias, bem como emissão de títulos a elas referentes.

Eram, portanto, tanto os leiloeiros quanto os institutos, terceiros privados que poderiam praticar o ato expropriatório, a configurar novo exemplo de desjudicialização privada incidental.

A defesa do executado seguiu sendo feita por meio de embargos, regulamentado nos artigos 1008 a 1016, exigida a garantia do Juízo e cabível somente nas execuções de títulos judiciais ${ }^{105}$. Eram apresentados diretamente ao juiz, que o processava e julgava tal como num processo de conhecimento, regulamentado na mencionada codificação como procedimento tipicamente judicializado.

Em síntese, o Código de 1939, em que pese não ter trazido alterações radicais à execução $^{106}$, apresentou desjudicializações incidentais em dois novos aspectos, a agregar à

\footnotetext{
${ }^{103}$ CASTRO, Amílcar de. Comentários ao Código de Processo Civil. Vol. X. T. I. 2 ed. São Paulo: Forense, 1963, p. 330.

${ }^{104}$ A título de exemplo, a Lei $\mathrm{n}^{\mathrm{o}}$ 5.601/70, que à época regulamentava a profissão dos corretores de fundos públicos, em seu artigo primeiro, dispunha que "observados os limites e condições estabelecidos pelo Conselho Monetário Nacional, as operações de compra ou venda de câmbio somente poderão ser contratadas com a interveniência de firmas individuais ou sociedades corretoras devidamente autorizadas pelo Banco Central do Brasil.".

${ }^{105}$ LUCON, Paulo Henrique dos Santos. Embargos à execução. São Paulo: Saraiva, 1996, p.79.

${ }^{106}$ LOBO DA COSTA, Moacir. Breve notícia histórica do Processo Civil brasileiro e de sua literatura. São Paulo: Editora Revista dos Tribunais, 1970, p. 100 e 101.
} 
figura já consolidada do depositário, quais sejam, a avaliação e a alienação dos bens penhorados por meio de agentes externos ao Judiciário.

\subsection{O atual regramento geral da execução por quantia}

Até aqui, observou-se que, ao longo da história, os principais regramentos da execução civil por quantia já contavam com desjudicializações incidentais. Houve, ainda, breve ampliação de atos tipicamente desjudicializados, a iniciar pela conservação do depósito, já nas Ordenações Filipinas, estendendo-se, a partir do Código de Processo Civil de 1939, para a avaliação e a alienação dos bens penhorados.

A despeito disso, os agentes encarregados pela condução e coordenação do processo, inclusive dos referidos atos de constrição e expropriação e a defesa do executado, assim como os sujeitos encarregados da prática da maior parte dos atos executivos, pertencem ao Poder Judiciário, a se confirmar constatação já feita por Cândido Rangel Dinamarco ${ }^{107}$.

Com o atual regramento não é muito diferente. O modelo executivo permanece, em linhas gerais, muito similar ao que se consolidou nos ordenamentos pretéritos, ou seja, preponderantemente judicializado, com grande concentração de atos nas mãos do juiz ${ }^{108}$.

Considerando o aspecto prospectivo do trabalho, nas próximas linha será analisada a legislação atual, a fim de que ela seja estabelecida como paradigma para um contraste futuro com um modelo executivo em que atue a desjudicialização.

Isto posto, de forma introdutória, registre-se que o principal tratamento da execução por quantia, atualmente, advém do Código de Processo Civil, Lei nº 5.869, de 11 de Janeiro

\footnotetext{
${ }^{107}$ DINAMARCO, Cândido Rangel. Execução civil. 8 ed. São Paulo: Malheiros, p. 82.

108 BATISTA SANTOS, Guilherme Luis Quaresma. Contraditório e execução. Rio de Janeiro: Lumen Juris, 2013, p. 189.
} 


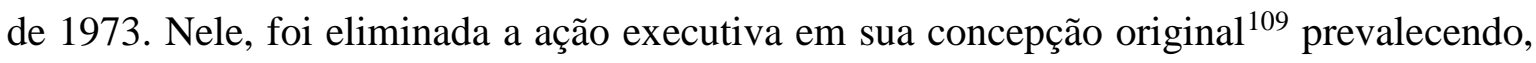
num primeiro momento, para todas as espécies de títulos executivos, um modelo similar ao processo executório do Código de 1939, que perdurou até a legislação reformista advinda principalmente, para a execução por quantia, com as Leis $n^{\circ} 11.232$ de 22 de dezembro de 2005 e no 11.382, de 06 de dezembro de 2006, quando foi instituído o processo sincrético para as execuções decorrentes de sentença ${ }^{110}$.

Em que pese ser a principal legislação a respeito do tema, o atual Código de Processo Civil não congregou e sistematizou toda a execução por quantia existente, tendo permanecido vigentes alguns diplomas legais esparsos tratando do tema ${ }^{111}$, casos da Lei $\mathrm{n}^{\mathbf{0}}$ 6.830/80, que regulamenta a execução fiscal, do Decreto-Lei no 70/66, que regulamenta a execução hipotecária dos Sistema Financeiro da Habitação, e da Lei no 5.741/71, que regulamenta a execução dos créditos do Sistema de Financiamento Imobiliário ${ }^{112}$. Como estes diplomas têm especial relevância para o trabalho, serão analisados detidamente no próximo capítulo.

Antes, nos itens seguintes, será traçado um perfil geral do atual regramento executivo brasileiro, a começar pelo modelo procedimental praticado atualmente para, em seguida, se

${ }^{109}$ GRECO, Leonardo. O processo de execução: volume I. Rio de Janeiro: Renovar, 1999, p. 47; MORAES, José Rubens de. Princípios da execução de sentença e reformas do Código de Processo Civil. Revista de Processo, São Paulo, ano 36, vol. 195, mai. 2011, p. 49.

${ }^{110}$ A alteração, em que pese ter rompido com o modelo liebmaniano de total autonomia entre o processo de execução e o de conhecimento, adotado originariamente no Código de 1973 (CÂMARA, Alexandre Freitas. $A$ nova execução de sentença. 4 ed. Rio de Janeiro: Lumen Juris, 2007, p. 16), e confinado conhecimento e execução numa mesma e contínua relação jurídica processual sem intervalos (LUCON, Paulo Henrique dos Santos. Nova execução de títulos judiciais e sua impugnação. In: WAMBIER, Teresa Arruda Alvim (coord.). Aspectos polêmicos da nova execução - 3: de títulos judiciais. São Paulo: Editora Revista dos Tribunais, 2006, p. 442), na prática, a legislação promoveu alteração mais tímida do que poderia parecer num primeiro momento: houve apenas a eliminação da citação para o início da fase executiva nos casos de cumprimento de sentença (BEDAQUE, Jose Roberto dos Santos. Direito e processo: influência do direito material sobre o processo. 6 ed. São Paulo: Malheiros, 2011, p. 148; MORAES, José Rubens de. Princípios da execução de sentença e reformas do Código de Processo Civil. Revista de Processo, São Paulo, ano 36, vol. 195, mai. 2011, p. 41), permanecendo os mesmos atos de execução forçada tanto para um quanto para outro procedimento (THEODORO JÚNIOR, Humberto. As vias de execução no processo civil brasileiro. O cumprimento das sentenças e a execução dos títulos extrajudiciais visão do código atual e do projeto 8.046/2010 da Câmara dos Deputados. Revista de Processo, v. 201, p. 13, nov. 2013, p. 17).

${ }^{111}$ LIEBMAN, Enrico Tullio. Processo de execução. 5 ed. São Paulo: Saraiva, 1986, p. 14.

${ }^{112}$ GRECO, Leonardo. O processo de execução: volume I. Rio de Janeiro: Renovar, 1999, p. 48. 
analisar as alterações trazidas pelo vindouro Código de Processo Civil, a entrar em vigor a partir de março de 2016.

\subsubsection{A execução por quantia no Código atual (CPC/73)}

Neste ponto será abordado o procedimento executivo em sua essência, destacandose os principais atos concernentes à execução por quantia certa de títulos judiciais e extrajudiciais. $\mathrm{O}$ intento é pontuar o atual rito judicializado de execução a fim de permitir um contraste, no segundo e terceiro capítulos, com a desjudicialização empregada em outros modelos, permitindo-se, assim, uma análise concreta de possibilidades com a atual conformação.

Assim, desde logo, cabe destacar que, hoje, no Código de Processo Civil, após as reformas que sofreu notadamente até o ano de 2005, a execução por quantia conta com dois procedimentos comuns, ligeiramente distintos entre si.

O primeiro é um procedimento sincrético, doravante denominado cumprimento de sentença, em que, em um mesmo processo, a fase executiva segue-se imediatamente à fase de conhecimento. Tem respaldo no artigo 475-I e seguintes do Código de Processo Civil e é aplicável à maior parte dos títulos executivos judiciais, elencados no artigo 475-N da mencionada codificação ${ }^{113}$.

O segundo é um processo autônomo, doravante denominado execução autônoma, composto de uma única fase executiva em seu rito principal ${ }^{114}$. Tem respaldo no artigo 646

\footnotetext{
${ }^{113}$ Parcela significativa da doutrina, analisando a previsão do artigo 475-N, parágrafo único do Código de Processo Civil, destaca que títulos executivos judiciais como a sentença penal condenatória transitada em julgado, a homologação de sentença estrangeira e a sentença arbitral seguem rito híbrido, com exigência de petição inicial e citação do demandado para a deflagração do rito executivo - atos típicos da execução autônoma -, mas com os demais atos praticados nos ditames do cumprimento de sentença. Esta mescla foi a forma encontrada para, de um lado, respeitar as peculiaridades inerentes às constituições destes títulos e, de outro, se manter a homogeneidade dos títulos executivos judiciais, de modo que todos sigam o mesmo procedimento (por todos, NEVES, Daniel Amorim Assumpção. Manual de direito processual civil. 3 ed. São Paulo: Método, 2012, p. 802).

${ }^{114}$ Sem prejuízo de incidentes cognitivos, a exemplo do que se observa no artigo 672 , $\S 4^{\circ}$ do Código de Processo Civil.
} 
e seguintes do Código de Processo Civil e é aplicável aos títulos executivos extrajudiciais em geral, notadamente os elencados no artigo 585 do citado diploma.

Os procedimentos são semelhantes e, ao cumprimento de sentença, por força do artigo 475-R do Código de Processo Civil, são aplicadas, subsidiariamente, as normas da execução autônoma. A diferença entre eles, além da natureza do título executivo, reside, quanto ao procedimento, principalmente nos atos de início e formação da relação jurídica processual e na forma pela qual se concretiza a defesa do executado.

No cumprimento de sentença, o início se dá com um simples requerimento executivo formulado pelo credor nos próprios autos do processo de conhecimento, ao que se segue a intimação do devedor, por meio de seu advogado, para pagamento no prazo de quinze dias, sob pena de acréscimo de $10 \%$ a título de multa e subsequente expedição de mandados de penhora e avaliação, conforme artigo 475-J do Código de Processo Civil.

Após a garantia do juízo, no prazo de quinze dias, o devedor poderá apresentar impugnação ao cumprimento de sentença, alegando as matérias previstas no rol artigo 475L do Código de Processo Civil. Esta impugnação se conforma como incidente processual de conhecimento e, em regra, conforme artigo 475-M do mencionado diploma, não suspende o curso da execução.

Já na execução autônoma, o processo se inicia mediante a apresentação de petição inicial, a qual deverá ser distribuída perante o foro competente. Recebida, o executado será citado para, nos termos do artigo 652 do Código de Processo Civil, efetuar pagamento no prazo de três dias, sob pena de penhora.

No prazo de quinze dias da juntada do mandado de citação, independentemente de garantia do Juízo ${ }^{115}$, o executado poderá oferecer embargos à execução, alegando as matérias previstas no artigo 745 do Código, inclusive "qualquer matéria que lhe seria lícito deduzir

\footnotetext{
${ }^{115}$ A discrepância entre a exigência de garantia do juízo para impugnação ao cumprimento de sentença e a sua ausência nos embargos à execução autônoma se justificaria pelo maior grau de probabilidade de existência do direito do exequente no primeiro caso (LUCON, Paulo Henrique dos Santos. O novo perfil dos embargos à execução. In: CARNEIRO, Athos Gusmão; CALMON, Petrônio (org.). Bases científicas para um renovado direito processual. 2 ed. Salvador: Juspodivm, 2009, p. 837).
} 
como defesa em processo de conhecimento", já que a relação jurídica estampada no título extrajudicial que fundamenta a execução, até aquele momento, não foi submetida a qualquer exame judicial. Estes embargos tramitam como processo autônomo de conhecimento, distribuído por dependência ao executivo e, em regra, conforme artigo 739-A, não suspendem o curso da execução.

Afora estas peculiaridades, os atos executivos no cumprimento de sentença e na execução autônoma são essencialmente os mesmos e, em regra, são praticados sob controle direto do juiz, o que não impede que algumas exceções configurem desjudicialização parcial.

Os atos de avaliação, depósito e administração, a exemplo do que já ocorria em procedimentos anteriores, são os principais exemplos de atos passíveis de serem praticados de forma desjudicializada, a cargo de agentes privados, tratados genericamente como auxiliares da justiça pelo artigo 139 do Código de Processo Civil, remunerados por honorários arbitrados pelo juiz, a cargo da parte interessada ${ }^{116}$.

O depositário particular, a depender da situação concreta, ora é encarregado do depósito, ora da administração de bens penhorados. Sua atuação como responsável pela guarda e conservação de bens penhorados tem expressa previsão nos incisos I e III do artigo 666 do Código de Processo Civil. O inciso I prevê como depositário de dinheiro, pedras e metais preciosos os bancos públicos - desjudicialização administrativa - e, subsidiariamente, qualquer estabelecimento de crédito escolhido pelo juiz. O inciso III, por sua vez, prevê o depositário particular para guarda de bens residuais, ou seja, não atribuídos para os estabelecimentos de crédito e nem para os depositários judiciais.

Já na função de administrador ${ }^{117}$, o Código prevê as hipóteses nos artigos $677, \S 2^{\circ}$ e 678 , caput, podendo, inclusive, ser livremente escolhido pelas partes, tipo de investidura que, como se verá a seguir, não é a regra para este tipo de auxiliar da justiça.

\footnotetext{
116 ASSIS, Araken. Manual da execução. 14 ed. São Paulo: Editora Revista dos Tribunais, 2012, p. 809.

117 Como administrador, o depositário atua principalmente quando a penhora recair em estabelecimento comercial, industrial ou agrícola, bem como em semoventes, plantações ou edifício em construção, ocasiões em que fica incumbido de apresentar planos de administração e prestar contas ao juízo, além de indicar a forma de constrição e entregar o dinheiro ao credor, nos termos dos artigos 655-A, $\$ 3^{\circ}, 677$ e 678, todos do Código de Processo Civil.
} 
O perito avaliador, por sua vez, é agente privado chamado a atuar nos autos excepcionalmente, quando o oficial de justiça não for tecnicamente habilitado para indicar o valor de um bem móvel ou imóvel. Sua atividade é regulamentada nos artigos 475-J, §2 e 680, c.c. 420 e seguintes e 145, todos do Código de Processo Civil. Este último artigo traz como única exigência para escolha do perito que tenha nível universitário e seja inscrito no respectivo órgão de classe, sendo livre a escolha do juiz nas localidades onde não houver profissionais qualificados.

Além de tais figuras, consolidaram-se no Código de Processo Civil novos atos passíveis de ser assumidos por agentes particulares, tornando-os, pois, desjudicializados. Trata-se, notadamente, da alienação particular por meio de corretores credenciados junto ao Juízo e da alienação por meio de leiloeiros, também credenciados no Juízo.

A alienação particular praticada por corretores credenciados perante o Juízo foi instituída pela Lei $\mathrm{n}^{\circ}$ 11.382/2006 que, dentre outras alterações, acrescentou o artigo 685-C ao Código de Processo Civil. Por corretores pode-se entender "qualquer agente comercial

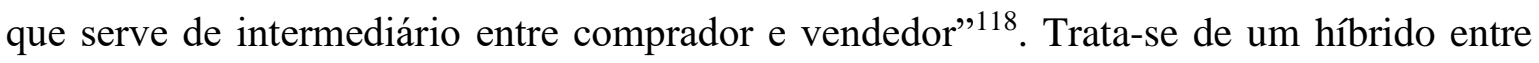
hasta pública presidida por particular e venda privada ${ }^{119}$.

O Código foi lacônico em sua previsão, limitando-se a exigir requerimento da parte e mínimo de cinco anos de exercício profissional para estes agentes, bem como autorizando que cada Tribunal expedisse provimentos detalhando o procedimento para este tipo de alienação. Diante disso, o detalhamento da atividade veio, no estado de São Paulo, por intermédio do Provimento no ${ }^{\circ} 1.496 / 2008$.

O leiloeiro público, por sua vez, já tinha previsão na codificação anterior e foi novamente contemplado no artigo 705 do Código de Processo Civil. Trata-se de agente

${ }^{118}$ NEVES, Daniel Amorim Assumpção. Manual de direito processual civil. 3 ed. São Paulo: Método, 2012, p. 1038.

${ }^{119}$ KNIJNIK, Danilo. Art. 685-C. In: ALVARO DE OLIVEIRA, Carlos Alberto (coord.). A nova execução de títulos extrajudiciais. Rio de Janeiro: Forense, 2006, p. 246. 
privado, profissional autônomo, auxiliar do comércio, com registro na Junta Comercial, a quem a lei defere a atribuição para a realização de leilões públicos ${ }^{120}$. Toda a atividade está regulada no Decreto $n^{\circ}$ 21.981/32, além da Instrução Normativa expedida pelo DNRC (IN $\left.n^{\circ} .113 / 2010\right)$.

Para exercer a função, é necessária a obtenção de matrícula perante a Junta Comercial do estado em que atuar (artigo $1^{\circ}$ do Decreto). Os artigos $2^{\circ}$ do Decreto e $3^{\circ}$ da Instrução Normativa DNRC, trazem os requisitos para o exercício da função. Além da apresentação de documentos, deve haver a comprovação de idoneidade por parte do profissional, bem como o recolhimento de um depósito, que poderá ser em dinheiro, fiança bancária ou seguro garantia a fim de caucionar o exercício da atividade (artigo $6^{\circ}$ do Decreto e $4^{\circ}$ e $5^{\circ}$ da IN 113/10).

Somente após a aprovação da caução e com a assinatura do termo de compromisso, a Junta Comercial competente procederá à matricula e expedirá a carteira de exercício profissional do leiloeiro.

O leiloeiro deve exercer sua função com exclusividade e pessoalidade, conforme artigos 11 e 19 do Decreto $\mathrm{n}^{\mathbf{0}}$ 21.981/32, sendo proibida a delegação da atividade, ressalvados os casos em que seja estritamente necessária, tanto que a delegação deve ser comunicada à Junta Comercial competente e segue regras estabelecidas quanto à escolha $\mathrm{e}$ habilitação do preposto (artigos $1^{\circ}$, parágrafo único e $7^{\circ}$ da IN DNRC 113/10).

$\mathrm{O}$ artigo 36 do Decreto $\mathrm{n}^{\circ}$ 21.981/32 e artigo 12 da Instrução Normativa 113/10 DNRC descrevem as proibições no exercício da função de leiloeiro, sob pena de destituição ou multa. Destacam-se a proibição de exercer o comércio, ainda que indiretamente ou em nome de outrem, de constituir sociedade, encarregar-se de cobranças ou pagamentos, adquirir para si ou para pessoa da família bem de cuja venda tenha sido incumbido, cobrar do arrematante valor diverso do estipulado em lei ou cobrar despesas relativas a reembolso

\footnotetext{
120 MACHADO, Antônio Cláudio da Costa. Código de Processo Civil Interpretado: artigo por artigo,
} parágrafo por parágrafo. 12 ed. Barueri, São Paulo: Manole, 2013. p.905. 
havidos com o leilão sem a expressa previsão no edital ou autorização do comitente ou autoridade judicial.

Quanto à remuneração, há, em regra, duas fontes principais. A primeira, regulamentada nos artigos 24 e 40 do Decreto $\mathrm{n}^{\circ}$ 21.981/32, é uma taxa de comissão decorrente do contrato estabelecido entre o comitente e o leiloeiro - contrato de mandato ou comissão -, que poderá ser definida por convenção entre as partes e de acordo com os bens a serem leiloados $^{121}$. Na falta de estipulação, aplicam-se os percentuais de $3 \%$ para imóveis de qualquer natureza, e $5 \%$ sobre os demais bens móveis.

O direito a esta verba autoriza o leiloeiro a cobrar judicialmente a quantia, além de lhe deferir o poder de retenção dos bens até que seja ressarcido pelo devedor.

A segunda forma de remuneração do leiloeiro é devida pelos arrematantes, aos quais compete o pagamento de $5 \%$ sobre qualquer bem arrematado (artigo 24, parágrafo único do Decreto $n^{\circ} 21981 / 32$ ).

O direito a este valor, nos termos do artigo 39 do Decreto $n^{\circ} 21.981 / 32$, defere ao leiloeiro o poder de rescindir a venda ou demandar judicialmente o arrematante, caso não seja efetuado o pagamento no prazo estipulado no leilão. Neste caso, o sinal ou caução dado pelo arrematante no ato da compra, fica retido em favor do leiloeiro e do credor. Deste valor será descontada a comissão e custas do leilão, podendo o remanescente ser cobrado em ação executiva, instruída com certidão do leiloeiro de que o valor da arrematação não foi pago no prazo estipulado. O decreto dá autonomia na atuação do leiloeiro perante o arrematante do bem.

No atual Código de Processo Civil, o leiloeiro está previsto apenas para fins de condução de alienação judicial, cujo procedimento é tratado nos artigos 686 a 707 do

${ }^{121}$ Os critérios de contratação, bem como a escolha do leiloeiro, ficarão a cargo dos interessados, ocorrendo sob suas exclusivas confianças, inclusive nas alienações judiciais, conforme parágrafos $2^{\circ}$ e $3^{\circ}$ do artigo 10 da Instrução Normativa n 13/10 DNRC. A jurisprudência tem discutido alguns aspectos para que a convenção da comissão não suplante os interesses do processo executivo e das partes, tratando, por exemplo, da necessidade de pagamento caso a arrematação não se confirme. A este respeito v. BORGES, Marcus Vinícius Motter. A prevalência do interesse da execução: hipóteses controvertidas de cabimento da comissão do leiloeiro a partir de julgados do Superior Tribunal de Justiça. In: LAMY, Eduardo; ARAÚJO, José Henrique Mouta; BORGES, Marcus Vinícius Motter. Aspectos polêmicos da execução civil. São Paulo: Conceito Editorial, 2012, passim. 
mencionado diploma. Nesta função, é indicado pelo exequente e designado pelo juiz, sendo sua atuação restrita aos ditames legais, a ele cabendo, notadamente, publicar o edital da alienação, realizar o leilão, expor aos pretendentes os bens ou as amostras das mercadorias, receber do arrematante a comissão estabelecida em lei ou arbitrada pelo juiz e receber e depositar, em vinte e quatro horas, à ordem do juiz, o produto da alienação, prestando contas nas quarenta e oito horas seguintes.

A Lei $n^{\circ} 11.382 / 2006$ trouxe importante inovação que repercutiu significativamente na atuação do leiloeiro, qual seja, o leilão eletrônico, previsto no artigo 689-A do Código de Processo Civil ${ }^{122}$, realizado a cargo de entidade particular, considerado o germe do fim da hasta pública, dada a dispensa de presença física do leiloeiro e dos licitantes ${ }^{123}$.

O leilão eletrônico tem previsão lacônica no artigo 689-A do Código, estando ali definidas a sua possibilidade mediante requerimento do exequente, a exigência de que o ente privado responsável pelo leilão seja conveniado com o Tribunal e que o procedimento atenda aos requisitos de ampla publicidade, autenticidade e segurança, com observância das regras estabelecidas na legislação sobre certificação digital. As minúcias e particularidades do procedimento, mais uma vez, foram deixadas a critério de cada Tribunal e, no Tribunal de Justiça do estado de São Paulo, o Conselho Superior da Magistratura editou o Provimento $\mathrm{n}^{\circ} 1.625 / 2009$ para tratar do assunto.

Segundo referido ato normativo, as entidades credenciadas para prestarem o serviço devem disponibilizar sítio onde os interessados em participar das alienações poderão realizar cadastro gratuito e oferecer lances em tempo real. A cada entidade cabe definir os critérios de participação com vistas à segurança e confiabilidade dos lances, conforme artigo $5^{\circ}$ do Provimento.

A entidade designada, suportando os custos de toda a operação - artigos 25 e 26 do Provimento -, deve divulgar a alienação nos termos fixados pela lei e pelo juiz, oferecendo

\footnotetext{
${ }^{122}$ Inclusive, o artigo $9^{\circ}$ do Provimento $\mathrm{n}^{\mathrm{o}} 1.496 / 2008$, prevê expressamente a possibilidade de se realizar a alienação particular por meio das regras e do ambiente virtual do leilão eletrônico enunciado no artigo 689-A do Código de Processo Civil, bastando, para tanto, prévia autorização judicial.

${ }^{123}$ AMARAL, Guilherme Rizzo. Art. 689-A. In: ALVARO DE OLIVEIRA, Carlos Alberto (coord.). A nova execução de títulos extrajudiciais. Rio de Janeiro: Forense, 2006, p. 122.
} 
o bem penhorado no site, com descrição detalhada e ilustrada de suas características e estado de conservação, podendo, ainda, visitar e providenciar visitas para os interessados no bem.

Os critérios de lances e a comissão devida pelo arrematante à entidade, nunca superior a 5\% sobre o valor da arrematação, devem ser previamente aprovados pelo Juízo artigos 16 e 17 do Provimento.

Publicado o edital, durante os três primeiros dias o bem é oferecido no valor da avaliação. Inexistindo lances, nos próximos vinte dias podem ser aceitos lances de até o limite mínimo de $60 \%$ do valor da avaliação, salvo determinação judicial em outro sentido.

Ao arrematante é expedida guia de depósito pelo próprio sistema, cuja efetivação, juntamente com o pagamento da comissão devida à entidade, viabiliza a assinatura do auto de arrematação pelo juiz, único e bastante subscritor do ato.

Esta previsão do juiz enquanto subscritor do ato de arrematação respeita a noção de que a transferência do bem por esta via não se dá como negócio privado de compra e venda, mas sim ato estatal imperativo ${ }^{124}$, movido pela substituição da vontade do devedor pelo Estado-Juiz. Aliás, ao juiz é dado amplo controle de todo o procedimento, não só tendo acesso imediato às decisões tomadas durante a alienação - artigo 23 do Provimento -, como também decidindo questões incidentais acerca dos critérios de cadastro e participação no certame - artigo $3^{\circ}$ do Provimento - e determinando o rastreamento do IP da máquina utilizada para oferecimento dos lances, se necessário - artigo 22 do Provimento. A despeito disso, o Tribunal de Justiça se exime de qualquer responsabilidade quanto ao uso do site, do provedor de acesso ou manutenção de softwares e hardwares do sistema - cf. artigo 25 e 27 do Provimento.

Em que pese, originariamente, o leiloeiro ter previsão para atuar apenas na alienação judicial, a prática forense e, mais recentemente, o artigo 880 do Novo Código de Processo Civil - abordado no item subsequente - estenderam sua utilização também como intermediário da alienação por iniciativa particular, ao lado dos corretores supracitados.

124 DINAMARCO, Cândido Rangel. Instituições de Direito Processual Civil - Volume IV. 3 ed. São Paulo: Malheiros, 2009, p. 650. 
Nesta função, a atual regulamentação da atividade do leiloeiro é a mesma do corretor, ou seja, o artigo 685-C do Código de Processo Civil e, no estado de São Paulo, o Provimento $\mathrm{n}^{\mathrm{o}} 1.496 / 2008$ do Conselho Superior da Magistratura.

Dispõe referido Provimento que, optando a parte pela alienação particular por meio de corretor ou leiloeiro, poderá ela própria escolher o profissional ou, silenciando a respeito, haverá designação pelo Juiz dentre os profissionais credenciados ${ }^{125}$.

O juiz, desde logo, fixará a comissão do profissional até o limite relativo de 5\% sobre o valor da transação - cf. artigo $3^{\circ}, \S 1^{\circ}$ do Provimento - e, caso a designação caiba ao próprio Juiz, fixará também prazo para se efetivar a alienação, preço mínimo, condições de pagamento e garantias para o caso de pagamento parcelado - cf. artigo $4^{\circ}$ do Provimento.

Eventuais intercorrências como ausência de interessados ou existência de interessados apenas para a aquisição por valor inferior ao mínimo estipulado, deverão ser comunicadas ao Juiz para deliberação, abrindo-se contraditório - cf. $\S \S 1^{\circ}$ e $2^{\circ}$ do artigo $4^{\circ}$ e artigo $7^{\circ}$, todos do Provimento.

O profissional designado deverá providenciar, às suas próprias expensas, ampla publicidade, preferencialmente eletrônica, em que deverá divulgar dados do processo, a data da penhora, existência de ônus sobre o bem ou sobre o proprietário, fotografias do bem, valores da avaliação e do preço mínimo fixado pelo juízo, condições de pagamento e garantias exigidas, comissão devida ao corretor e detalhes sobre o procedimento de alienação - principalmente dados do corretor ou leiloeiro responsável, referências quanto ao local e data para coleta de propostas, bem como ressalvas quanto aos riscos do negócio, tudo conforme artigo $6^{\circ}$ do Provimento.

Consumada, a alienação será formalizada por termo nos autos, lavrado pelo escrivãodiretor do respectivo cartório judicial e subscrito pelas partes, pelo juiz e pelo adquirente, expedindo-se carta de alienação para o registro imobiliário - se bem imóvel - ou mandado

${ }^{125}$ A forma pela qual o profissional se credencia junto ao Tribunal será tratada logo adiante. Por ora, importante destacar que, caso a parte opte por profissional não credenciado, a primeira providência do escolhido deverá ser o credenciamento. 
de entrega ao adquirente - se bem móvel. Uma vez formalizado o termo, a remissão prevista no artigo 651 do Código de Processo Civil deixa de ser eficaz como meio do executado manter a propriedade do bem.

Todos estes agentes privados supracitados, perito avaliador, depositário - exceto os bancos públicos -, corretor, leiloeiro e entidade encarregada de leilão eletrônico, se incluem na categoria doutrinária de auxiliares da Justiça, "pessoas a quem o sistema do processo atribui o encargo de realizar os serviços complementares à jurisdição, sob a autoridade do juiz" ${ }^{126}$, mais especificamente na subcategoria dos auxiliares eventuais da justiça, pessoas que não pertencem aos quadros fixos do Poder Judiciário - são acionados conforme a necessidade do caso concreto - e não têm obrigação de aceitar o encargo que lhes é designado, mas, uma vez no exercício de suas funções, configuram órgãos de encargo judicial subordinados ao juiz e às exigências por ele feitas ${ }^{127}$.

A despeito do múnus público, praticam os atos dos quais foram encarregados no âmbito privado, sendo responsáveis por suas respectivas atividades, adaptados, portanto, à noção de desjudicialização aqui praticada.

A mescla de múnus público com atividade privada não exime estes agentes do dever de respeito aos princípios da administração, notadamente à impessoalidade e seu principal desdobramento na função jurisdicional, a imparcialidade ${ }^{128}$.

O modo pelo qual são designados, à sorte do artigo 96, I da Constituição Federal, ressalvadas as observações feitas pelo Código em cada caso, é deixada a critério de cada Tribunal, enquanto entes autônomos para organizar suas secretarias e seus serviços.

\footnotetext{
${ }^{126}$ DINAMARCO, Cândido Rangel. Instituições de Direito Processual Civil - Volume I. 7 ed. São Paulo: Malheiros, 2013, p. 665.

${ }^{127}$ Os auxiliares eventuais se contrapõem aos auxiliares permanentes, estes integrantes do quadro funcional do Poder Judiciário e por ele remunerados, possuindo deveres permanentes e sendo subordinados ao juízo ao qual atrelados (Ibidem, p. 672-673).

${ }^{128}$ Ibidem, p. 666.
} 
No Tribunal de Justiça do estado de São Paulo, o tema é tratado genericamente pelo Provimento $n^{\circ} 797 / 2003$. No texto, há exigências mínimas que visam garantir os princípios básicos da administração, bem como a imparcialidade de tais profissionais.

Quando nomeados pela primeira vez, estes auxiliares têm de providenciar, em até dez dias, além de outros documentos que o juiz entenda necessários, sua qualificação pessoal - inclusive endereço eletrônico - e documentos que indiquem sua qualificação profissional, eventual vínculo de parentesco sanguíneo, por afinidade ou civil com juízes e servidores da respectiva unidade judiciária e certidões de distribuidores de cartórios judiciais. Toda a documentação é autuada na forma de prontuário e submetida a exame e aprovação do juiz. Este prontuário fica disponível para consulta das partes e eventuais interessados e o credenciado deve atualizá-lo a cada dois anos, sob pena de inutilização.

O cadastro pode ainda ser feito diretamente pelos órgãos oficiais de classe de cada grupo profissional e utilizados pelo Judiciário mediante a celebração de convênio com a referida entidade.

Diante de todo o exposto e de forma conclusiva, pode-se dizer que o atual Código de Processo Civil, em que pese, comparativamente com o diploma anterior, não ter inovado substancialmente em termos de desjudicialização, estabeleceu sistemas que aprimoraram a participação de terceiros externos ao judiciário, notadamente nos casos de depósito, avaliação e alienação de bens penhorados, inclusive adicionando mecanismo de alienação eletrônica por meio de empresa habilitada junto ao juízo.

Sem prejuízo, permaneceu um sistema de contato direto e constante com o EstadoJuiz, com a maioria dos atos praticados por agentes judiciários, a configurar, mais uma vez, modelo preponderantemente judicializado com desjudicializações incidentais.

\subsubsection{Alterações do Novo Código de Processo Civil (NCPC)}

No dia 17 de março de 2015 foi publicada a Lei ${ }^{\circ} 13.115$ de 16 de março de 2015, que estabelece um novo Código de Processo Civil. Com vacatio legis de um ano, sua vigência iminente demanda uma abordagem da nova codificação sob o viés da desjudicialização executiva. 
A despeito de todo um novo regramento, que trouxe uma série de inovações ao Processo Civil brasileiro, no que concerne, especificamente, à execução, há certo consenso de que não houve alterações em sua essência ${ }^{129}$, de modo que também o modelo executivo - preponderantemente judicializado - se manteve, com breves alterações.

Tendo em vista a importância do tema, a seguir traremos um panorama geral da execução no novo Código, atentando para as alterações mais relevantes, destacando, se for o caso, movimentações que indiquem uma alteração no modelo judicializado e comparando com as hipóteses de desjudicialização preexistentes, já destacadas no capítulo anterior.

\subsubsection{Disposições gerais}

Os requisitos essenciais para a realização da execução foram mantidos tais como previstos no código anterior, já que é necessária a apresentação de título executivo que represente obrigação certa, líquida e exigível, previsão expressamente trazida pelo artigo 783 do Novo Código de Processo Civil (NCPC). Também nos mesmos termos do Código atual os artigos 786, 787 e 788 do NCPC, que complementam a questão da exigibilidade prevista no artigo 783.

Os artigos 789 a 796 fixam as balizas do princípio da responsabilidade patrimonial do devedor, já vigente no Código de Processo Civil atual, porém com novos aspectos, como a sujeição dos bens do responsável em casos de desconsideração da personalidade jurídica, os limites para constrição de direitos de superfície, enfiteuse e de uso, modo de constatação e desdobramentos da fraude à execução e restrições à responsabilidade subsidiária do fiador com relação à do devedor principal e do sócio com relação à da sociedade.

\footnotetext{
129 THEODORO JÚNIOR, Humberto. As vias de execução no processo civil brasileiro. O cumprimento das sentenças e a execução dos títulos extrajudiciais visão do código atual e do projeto 8.046/2010 da Câmara dos Deputados. Revista de Processo, v. 201, p. 13, nov. 2013, p. 4; REETZ DE PAIVA, Daniela. A desjudicialização dos atos executórios. Escola da magistratura do estado do Rio de Janeiro - Série aperfeiçoamento de magistrados, Curso "Fomento Mercantil - Factoring", n. 9, Rio de Janeiro, out. 2011, p. 34.
} 
Ainda na esfera da responsabilidade patrimonial, o artigo 805 do NCPC manteve o princípio da menor onerosidade ao devedor, porém impôs ônus ao executado de indicar outros meios mais eficazes e menos onerosos de ataque ao seu patrimônio, sob pena de manutenção dos atos já determinados.

Estes atos, aliás, sofreram importante alteração, introduzida pelo artigo 139, inciso IV do NCPC. Com vistas a permitir maior efetividade na prestação da tutela, a nova legislação processual civil modificou o poder executivo conferido ao juiz, traçando como um dos poderes e deveres do juiz "determinar todas as medidas indutivas, coercitivas, mandamentais ou sub-rogatórias necessárias para assegurar o cumprimento de ordem judicial, inclusive nas ações que tenham por objeto prestação pecuniária".

Em que pese este dispositivo reafirmar o disposto nos artigos 461 e 461-A do Código vigente, a previsão se restringia às obrigações de fazer, não fazer e entrega de coisa ${ }^{130}$. A redação do NCPC não conta com esta restrição, estendendo esta liberdade do juiz também às obrigações de pagar quantia. Trata-se da atipicidade dos meios executivos ${ }^{131}$ aplicada a todas as formas de prestação ${ }^{132}$, extensão da norma aberta à modalidade em questão ${ }^{133}$, que, inclusive, já contava com adeptos na doutrina ${ }^{134}$.

\footnotetext{
${ }^{130}$ MOREIRA, Alberto Camiña. A execução para entrega de coisa. In: MOREIRA, Alberto Camiña et.al. Nova reforma processual civil comentada. 2 ed. São Paulo: Editora Método, 2003, p. 390.

${ }^{131}$ Consistente na ampliação de poderes do juiz, sendo a ele conferida a possibilidade de introduzir medidas executivas não previstas em lei com vistas ao adimplemento da obrigação (JORGE, Flavio Cheim. Relação processual e contraditório nas diversas espécies de execução. In: DIDIER JR., Fredie (coord.). Execução civil: estudos em homenagem ao professor Paulo Furtado. Rio de Janeiro: Editora Lumen Juris, 2006, p. 103). Sua contrapartida é a exigência de justificação das escolhas e o controle por meio da proporcionalidade (MARINONI, Luiz Guilherme. Controle do poder executivo do juiz. In: DIDIER JR., Fredie (coord.). Execução civil: estudos em homenagem ao professor Paulo Furtado. Rio de Janeiro: Editora Lumen Juris, 2006, p. 245).

${ }^{132}$ MARINONI, Luiz Guilherme; ARENHART, Sérgio Cruz; MITIDIERO, Daniel. Novo curso de processo civil: tutela dos direitos mediante procedimento comum - volume II. São Paulo: Editora Revista dos Tribunais, 2015, p.761.

${ }^{133}$ MARINONI, Luiz Guilherme. Ideias para um "renovado direito processual". In: CARNEIRO, Athos Gusmão; CALMON, Petrônio (org.). Bases científicas para um renovado direito processual. 2 ed. Salvador: Juspodivm, 2009, p. 140.

${ }_{134}$ BAUMÖHL, Debora Ines Kram. A nova execução civil: a desestruturação do processo de execução. São Paulo: Atlas, 2006, p. 148.
} 
A extensão de tal liberdade já é objeto de divergência na doutrina, havendo quem entenda que a atipicidade dos meios executivos nas obrigações de pagar quantia se aplica, apenas e tão-somente, às execuções fundadas em títulos judiciais.

Segundo este segmento doutrinário, as inúmeras as possibilidades de constituição de um título extrajudicial - unilateral, em algumas hipóteses -, bem como a ausência de controle judicial prévio, exigiriam maior cautela em seu cumprimento, de modo a evitar injustas incursões no patrimônio do devedor, motivo pelo qual a previsão do artigo 139, IV não seria a eles extensível, mantida, portanto, neste particular, a tipicidade ${ }^{135}$ dos meios de execução ${ }^{136}$.

Já a corrente divergente, que estende a atipicidade para ambas as espécies de títulos executivos, considera que a intenção legislativa, disposta na parte final do inciso IV, tem por finalidade deixar claro o uso do artigo e ampliar as medidas de efetivação, de modo a restar inequívoca a sua aplicação às execuções de pagar quantia, inclusive naquelas fundadas em títulos extrajudiciais ${ }^{137}$.

\footnotetext{
${ }^{135}$ Se dá quando ao juiz não socorre qualquer liberdade para escolha do meio executivo, devendo ficar adstrito aos ditames legais (JORGE, Flavio Cheim. Relação processual e contraditório nas diversas espécies de execução. In: DIDIER JR., Fredie (coord.). Execução civil: estudos em homenagem ao professor Paulo Furtado. Rio de Janeiro: Editora Lumen Juris, 2006, p. 101). Objetiva proteger o jurisdicionado contra eventual arbítrio no uso da execução (MARINONI, Luiz Guilherme. Controle do poder executivo do juiz. In: DIDIER JR., Fredie (coord.). Execução civil: estudos em homenagem ao professor Paulo Furtado. Rio de Janeiro: Editora Lumen Juris, 2006, p. 225).

${ }^{136}$ MARINONI, Luiz Guilherme; ARENHART, Sérgio Cruz; MITIDIERO, Daniel. Novo curso de processo civil: tutela de direitos mediante procedimentos diferenciado - volume III. São Paulo: Editora Revista dos Tribunais, 2015. p. 84-85.

${ }^{137}$ MINAMI, M.Y. Breves apontamentos sobre a generalização das medidas de efetivação no CPC/2015 - do processo para além da decisão. In: DIDIER JUNIOR, Fredie (coord.). Novo CPC doutrina selecionada - v.5 execução. Salvador: Juspodivm, 2015. p. 225. Destaque para o esclarecimento feito pelo autor no tocante à expressão "ordem judicial", disposta no artigo 139, inciso IV. Para ele, alguns defenderiam a não aplicação do artigo na execução de títulos extrajudiciais justamente pela ausência de ordem judicial nesses documentos. No entanto, destaca que "ao verificar que uma decisão não atingiu seus efeitos desejados, que algum direito (seja sua origem título executivo judicial ou extrajudicial) permaneceu violado ou está na iminência de sofrer um ilícito, deve o magistrado, quando o caso assim exigir, se valer das medidas de efetivação em decisão fundamentada (e eis aqui a ordem judicial), deixando claro qual a prestação devida e qual a medida que aplicará para o caso, seja de coerção ou de sub-rogação" (ibidem, p. 224). Portanto, contornado o argumento, é cabível a aplicação do dispositivo também para os títulos extrajudiciais.
} 
Este último entendimento foi endossado ao final do Fórum Permanente de Processualistas Civis ocorrido em maio de 2015, por meio da edição do Enunciado no 12 , cujo teor direciona a aplicação do artigo 139 , inciso IV já referido ${ }^{138}$.

A análise minuciosa de tal liberdade exige abordagem dedicada, de modo que descabem maiores digressões a este respeito. Apenas registre-se, por fim, certa pacificidade na doutrina quanto aos limites das medidas coercitivas e indutivas na excepcionalidade de seu uso - apenas quando os meios típicos se revelarem ineficazes -, na proporcionalidade considerada a menor onerosidade para o devedor - e na necessidade de fundamentação substancial da decisão ${ }^{139}$.

Ainda com vistas à efetividade da execução e ao poder coercitivo do juiz, o inciso III do artigo 772 e o artigo 773 do NCPC facultaram ao juiz, de ofício ou a requerimento, requisitar que sujeitos indicados pelo exequente forneçam informações relacionadas ao objeto da execução, determinando as medidas que se fizerem necessárias para o cumprimento da ordem. No mesmo sentido, os parágrafos $3^{\circ}$ e $4^{\circ}$ do artigo 782 introduziram a medida coercitiva de inclusão do nome do executado nos cadastros de inadimplência, a ser determinada pelo juiz a requerimento da parte.

Finalmente, quanto aos títulos executivos, o artigo 515 traz o rol dos títulos judiciais. Merece destaque o inciso I, que ampliou a incidência dos atos de execução para toda e qualquer decisão proferida no processo civil, o que inclui as decisões interlocutórias, as monocráticas proferidas no âmbito dos Tribunais, além das sentenças ${ }^{140}$. O artigo põe fim à dúvida quanto ao caráter executivo daquelas decisões.

\footnotetext{
138 BUENO, Cassio Scarpinella. Novo Código de Processo Civil anotado. São Paulo: Saraiva, 2015, p.138. Prevê o enunciado que "A aplicação das medidas atípicas sub-rogatórias e coercitivas é cabível em qualquer obrigação no cumprimento de sentença ou execução de título executivo extrajudicial. Essas medidas, contudo, serão aplicadas de forma subsidiária às medidas tipificadas, com observação do contraditório, ainda que diferido, e por meio de decisão à luz do art. 499, § $1^{\circ}$, I e II (art. 489, §1 ${ }^{\circ}$, I e II, do novo CPC)".

139 GAJARDONI, Fernando da Fonseca. A revolução silenciosa da execução por quantia. Disponível em <http://www. jota.info/a-revolução-silenciosa-da-execução-por-quantia>. Acesso em 16 set. 2015.

${ }^{140}$ BUENO, Cassio Scarpinella. Novo Código De Processo Civil anotado. São Paulo: Saraiva, 2015, p. 343344.
} 
Como peculiaridade do artigo 515, inciso I, salienta-se a necessidade de demonstrar a exigibilidade da obrigação e não sua existência, conforme redação anterior (artigo 475-N do $\mathrm{CPC} / 73)$. Esta característica leva parta da doutrina a defender o afastamento definitivo da ideia de que as sentenças meramente declaratórias ostentam caráter executivo, uma vez que não são dotadas de exigibilidade ${ }^{141}$.

$\mathrm{O}$ inciso $\mathrm{V}$ do artigo 515 incluiu como título judicial o crédito do auxiliar da justiça - e não mais apenas do serventuário. E por fim, o inciso IX inovou ao definir que também é título a decisão interlocutória estrangeira após a concessão do exequatur (ordem de cumprimento) pelo Superior Tribunal de Justiça.

Na sequência, ganha relevância o disposto no artigo 517 ao prever o protesto da decisão judicial transitada em julgado, após o lapso temporal previsto para pagamento voluntário, baseado na eficiência que o protesto gera socialmente ${ }^{142}$. A medida é coercitiva, fica à disposição do exequente e, o artigo é expresso ao determinar sua aplicação apenas para as decisões que espelham obrigação de pagar quantia. Na prática poderá constituir meio efetivo de cumprimento da obrigação.

Os títulos executivos extrajudiciais encontram previsão no artigo 784 do NCPC em rol novamente não taxativo, ao qual foram acrescidos os créditos de natureza condominial e as certidões expedidas por serventia relativa a valores de emolumentos e demais despesas fixadas em lei.

\subsubsection{Início e defesa do executado}

${ }^{141}$ BUENO, Cassio Scarpinella. Novo Código De Processo Civil anotado. São Paulo: Saraiva, 2015, p. 344. Em sentido diverso, Teresa Arruda Alvim Wambier, destaca: "Segundo pensamos, as sentenças declaratórias (inclusive as de improcedência) são executáveis quando explicitarem todos os elementos de uma prestação exigível. A nosso ver não faz sentido impor nova fase de cognição para explicitar um comando condenatório a uma sentença que já contém todos os elementos identificadores da obrigação."(Primeiros comentários ao novo código de processo civil: artigo por artigo. São Paulo: Editora Revista dos Tribunais, 2015, p. 846-847).

142 BUENO, Cassio Scarpinella. Novo Código De Processo Civil anotado. São Paulo: Saraiva, 2015, p. 346. 
A dicotomia de procedimentos - uma fase processual em regra para títulos judiciais e um processo autônomo em regra para títulos extrajudiciais - foi mantida ${ }^{143}$, havendo uma reorganização dos assuntos no Código, sendo o cumprimento de sentença tratado no Livro I, Título II - artigo 513 e seguintes - e a execução autônoma no Livro II, Título I - artigo 771 e seguintes - da nova legislação.

No cumprimento de sentença foi mantido o início por meio de requerimento da parte credora - artigo 513 -, seguido da intimação do devedor, preferencialmente por simples publicação no Diário da Justiça em nome do advogado deste último ${ }^{144}$.

O artigo 524 prevê que o requerimento inicial deve conter, em essência, a identificação juntamente com o CPF ou CNPJ do devedor, indicação de bens passíveis de penhora e demonstrativo discriminado e atualizado do crédito.

A intimação do devedor, por sua vez, nos termos do artigo 523, será para que pague o crédito no prazo de 15 dias. Efetuado o pagamento, extingue-se o feito em razão do cumprimento da obrigação. Não efetuado ou feito parcialmente, sobre o saldo incide multa e honorários no importe de $10 \%$ e sobrevém a expedição do mandado de penhora e avaliação de bens ${ }^{145}$.

Ao término destes mesmos 15 dias, inicia-se o prazo para que o devedor ofereça impugnação ${ }^{146}$, mecanismo mantido como meio de defesa no cumprimento de sentença,

143 BATISTA SANTOS, Guilherme Luis Quaresma. Teoria geral da execução e o Código de Processo Civil Brasileiro de 2015. In: DIDIER JUNIOR, Fredie (coord.). Novo CPC doutrina selecionada - v.5 execução. Salvador: Juspodivm, 2015. p. 42.

${ }^{144}$ WAMBIER, Teresa Arruda Alvim; et al. Primeiros comentários ao novo código de processo civil: artigo por artigo. São Paulo: Editora Revista dos Tribunais, 2015, p. 842-843.

${ }^{145}$ Merece destaque a norma do artigo 526, que abre a possibilidade de o executado se manifestar antes de ser intimado do cumprimento de sentença, juntando memória de cálculo e depositando o valor que entender devido a partir do título judicial. É mais uma oportunidade para o cumprimento da obrigação. Uma vez efetuado o depósito, o exequente será intimado para se manifestar em 5 dias. Se concordar com o valor ou silenciar, considerar-se-á satisfeita a obrigação e a execução será extinta. Se impugnar o valor e for procedente, incidirá a multa e honorários sobre o valor restante e prosseguem-se os atos até saldar o valor restante.

${ }^{146}$ Neste ponto já há críticas doutrinárias, indicando excesso de prazo para defesa, uma vez que o executado que não tiver qualquer interesse em adimplir com a obrigação ainda gozará de um total de 30 dias para elaborar sua defesa - 15 dias de prazo para pagamento mais os 15 dias de prazo para oferecer sua impugnação (WAMBIER, Teresa Arruda Alvim; et al. Primeiros comentários ao novo código de processo civil: artigo por artigo. São Paulo: Editora Revista dos Tribunais, 2015, p. 871). 
previsto no artigo 525 e com rol taxativo de matérias passíveis de serem arguidas elencadas no $\S 1^{\circ}$ da mesma referência.

Neste ato há duas novidades dignas de nota. A primeira é que foi dispensada a exigência de penhora ou garantia do juízo. Em contrapartida, foi alterada a concepção acerca dos efeitos em que é recebida a impugnação, de modo que, na nova codificação, em regra, a apresentação de impugnação ao cumprimento de sentença não suspende a execução.

Os $\S \S 6^{\circ}$ a $10^{\circ}$ do artigo 525 preveem a possibilidade excepcional de concessão do efeito suspensivo, a requerimento do exequente e a julgo do juiz. Neste caso, porém, deverá haver garantia do juízo, via penhora, depósito ou caução suficientes. Mesmo quando deferido o efeito suspensivo, o $\S 10^{\circ}$ prevê a possibilidade de o exequente prestar caução e requerer o prosseguimento dos atos executivos.

As questões relativas a fatos supervenientes ao término do prazo para apresentação da impugnação, assim como aquelas relativas à validade e à adequação da penhora, da avaliação e dos atos executivos subsequentes, passam a poder ser arguidas por simples petição, tendo o executado, em qualquer dos casos, o prazo de 15 (quinze) dias para formular esta arguição, contado da comprovada ciência do fato ou da intimação do ato, conforme previsão do $\S 11$ do artigo $525^{147}$.

Os demais atos de constrição e expropriação seguem o rito previsto para o processo autônomo de execução por quantia, conforme previsto no artigo 771 do Novo Código de Processo Civil.

\footnotetext{
${ }^{147}$ Teresa Arruda Alvim Wambier interpreta este dispositivo de modo conjugado com o artigo 518 do mesmo diploma - pelo qual "todas as questões relativas à validade do procedimento de cumprimento da sentença e dos atos executivos subsequentes poderão ser arguidas pelo executado nos próprios autos e nestes serão decididas pelo juiz" - de modo a enunciar o fim da exceção de pré-executividade. Segundo a autora, as matérias conhecidas pelo devedor até a data de apresentação da impugnação ao cumprimento de sentença, devem ser arguidas na peça defensiva, quer sejam de ordem pública ou não. Fatos supervenientes ou matérias cujo conhecimento se deu após o prazo de defesa, será cabível a arguição por meio de simples petição (Primeiros comentários ao novo código de processo civil: artigo por artigo. São Paulo: Editora Revista dos Tribunais, 2015, p. 876.).
} 
Este processo autônomo, por sua vez, permanece com um início distinto daquele previsto para o cumprimento de sentença. Distribuída a inicial ao juízo competente ${ }^{148}-$ as regras para instrução da inicial e requerimentos de intimações de pessoas específicas estão previstas nos artigos 798 e 799 do NCPC -, o executado é citado para efetuar o pagamento no prazo de 3 dias. $\mathrm{O}$ mandado inicial de citação deve prever honorários advocatícios de $10 \%$ - se o pagamento se der no prazo regulamentar, este valor é reduzido pela metade -, além de já constituir ordem de penhora e avaliação, conforme artigos 827 e 829, parágrafo $1^{\circ}$ do NCPC.

A penhora e avaliação são praticadas, em regra, por Oficial de Justiça ao final dos 3 dias previstos para pagamento, seguindo-se a intimação do executado (artigo 829). O novo Código manteve, em seu artigo 830, a possibilidade do arresto de bens do executado que não for localizado, também exercido por Oficial de Justiça.

Este último, aliás, por força do artigo 782 do NCPC, foi mantido como responsável, em regra, pela prática de atos executivos determinados pelo juiz, principais características a configurar o procedimento executivo também do novo Código como preponderantemente judicializado.

Os embargos, tratados nos artigos 914 a 920 do NCPC, permanecem como mecanismo de defesa disponível para o executado nas execuções autônomas. Seu ajuizamento deve se dar independentemente de garantia do juízo, no prazo de 15 dias a contar do termo inicial da comunicação do executado, conforme regras introduzidas no artigo 231 do NCPC. As matérias passíveis de serem arguidas seguem com amplo rol no novo artigo 917, ali acrescentadas as possibilidades de se alegar a inexequibilidade do título ou inexigibilidade da obrigação em lugar da nulidade de execução "por não ser executivo o título apresentado", do atual inciso I do artigo 745, e a incompetência do juízo executivo.

Outra importante inovação foi a previsão de abertura de contraditório antes da aprovação do parcelamento insculpido no atual artigo 745-A - artigo 916 do NCPC -, e a

\footnotetext{
148 O Novo Código trouxe em seu artigo 781 regras específicas de competência para o processo autônomo de execução, prevendo hipóteses de foros concorrentes e a possibilidade de eleição conforme o título executivo extrajudicial.
} 
expressa menção de que a opção pelo parcelamento implica da renúncia, por parte do executado, de seu direito de opor embargos. Finalmente, sanando divergência jurisprudencial, também restou expressamente vedado este parcelamento no cumprimento de sentença.

\subsubsection{Constrição e expropriação}

Especificamente, quanto à penhora, não há inovações substanciais no novo CPC. Considera-se concluída com a apreensão e depósito dos bens, lavrando-se o auto de penhora (artigo 839) do qual o executado é intimado, preferencialmente, na pessoa de seu advogado, conforme artigo 841. As disposições acerca do lugar de realização da penhora e de suas modificações sofreram pouca ou nenhuma alteração, sendo regulamentadas nos artigos 845 a 851 do NCPC. Foram criadas regulamentações específicas quanto aos ritos das penhoras de dinheiro em depósito ou em aplicação financeira - artigo 854 -, de quotas ou ações de sociedades personificadas - artigo 861 - e de percentual de faturamento da empresa - artigo 866.

Quanto ao depósito, foi suprimida a figura do depositário particular, anteriormente prevista no inciso III do artigo $666^{149}$. A despeito disso, foram mantidas as hipóteses desjudicializadas dos bancos públicos ou de outro estabelecimento de crédito como depositários de dinheiro ou pedras e metais preciosos e consolidou-se a figura do administrador-depositário, nos exatos termos outrora previstos nos artigos 677 e 678, agora nos artigos 862 e 863 - penhora de empesa, outros estabelecimentos e de semoventes - e também nos artigos 861 - na penhora de quotas ou ações de sociedades personificadas -,

149 O artigo 840 - equivalente na nova codificação -, prevê apenas as figuras do banco público ou estabelecimento financeiro particular, o depositário judicial e, subsidiariamente, o repasse do encargo ao exequente. 
866 - penhora de percentual de faturamento de empresa -, e 867 a 869 - penhora de frutos e rendimentos de coisa móvel ou imóvel -, todos do NCPC.

Na avaliação, o artigo 870 manteve a atribuição, em regra, com os Oficiais de Justiça. A ressalva fica por conta do disposto no parágrafo único, pois, havendo necessidade de conhecimentos especializados e o valor da execução comportar ${ }^{150}$, pode o juiz nomear o perito avaliador, mesma figura desjudicializada prevista nos artigos 475-J, $\S 2^{\circ}$ e 680 da antiga codificação. A nova codificação traz previsão inédita em seu artigo 471 no sentido de permitir que não apenas o juiz, mas também as partes, em comum acordo, mediante requerimento, possam designar o perito.

Quanto aos requisitos para designação do perito, o atual artigo 145 foi substituído pelo artigo 156 do NCPC, mais minucioso do que seu antecessor. Na nova redação, o profissional deve ser escolhido dentre aqueles habilitados em órgãos técnicos ou científicos inscritos em cadastro mantido pelo Tribunal - abolida a referência aos órgãos de classe, portanto -, sendo cada órgão obrigado a fornecer nomes e dados de qualificação de cada profissional de modo a permitir eventual juízo de imparcialidade ou impedimento.

Estes órgãos devem ser cadastrados a partir de consulta pública realizada pelos Tribunais junto universidades, conselhos de classe, Ministério Público, Defensoria Pública e Ordem dos Advogados do Brasil, e mediante divulgação na internet e em jornais de grande circulação. O cadastro deve sofrer manutenções periódicas, procedendo o Tribunal com reavaliações que tenham em vista a formação profissional, a atualização do conhecimento e a experiência dos peritos interessados, sem que o Código especifique de que forma se dará esta análise.

Também a designação de perito nas localidades em que não houver profissional inscrito no cadastro do Tribunal sofreu alterações. O juiz já não goza da ampla liberdade

\footnotetext{
${ }^{150}$ A dicção do parágrafo único indica que o juiz deve estar atento ao custo da perícia para que não suplante o valor da obrigação a ser cumprida, ocasião em que pode ser inviável a designação do perito avaliador (BUENO, Cassio Scarpinella. Novo Código De Processo Civil anotado. São Paulo: Saraiva, 2015, p. 529).
} 
prevista no código vigente, devendo escolher profissional ou órgão técnico ou científico “comprovadamente detentor do conhecimento necessário à realização da perícia”.

As demais disposições quanto aos atos que levam à produção da prova pericial, anteriormente constantes nos artigos 420 e seguintes do Código de Processo Civil, sofreram pequenas complementações nos novos artigos 464 a 480 do NCPC, sem que sua estrutura sofresse alterações substanciais, o mesmo se dando com o procedimento de avaliação, previsto nos artigos 871 a 874 do NCPC. Por fim, o artigo 875 encerra a ordem de atos e inaugura a fase de expropriação de bens.

Finalmente, no que concerne à expropriação dos bens, a nova codificação articula, no artigo 825, que a expropriação se dará de três formas: adjudicação, alienação e apropriação de frutos e rendimentos de empresa ou de estabelecimento e de outros bens. Conforme ressalva a doutrina, a ordem disposta é preferencial e deve ser respeitada, observadas as peculiaridades do caso concreto ${ }^{151}$.

A adjudicação, tratada nos artigos 876 a 878 do NCPC, é a primeira forma expropriatória prevista. O rol de possíveis requerentes foi significativamente ampliado, contemplando, além daqueles já legitimados na atual codificação, o companheiro e pessoas que já possuam direito ou expectativa de direito sobre o bem penhorado, elencadas nos incisos II a VIII do artigo 889 do NCPC. Foi adicionada, ainda, a previsão de se recorrer novamente à adjudicação em caso de frustração das tentativas de alienação.

A alienação, por sua vez, tem previsão nos artigos 879 a 903 do NCPC. Foi mantida a possibilidade de sua antecipação nos casos de depreciação, deterioração e manifesta vantagem. A previsão, agora insculpida no artigo 852 do NCPC - atual artigo 670 delimitou que a antecipação da venda somente pode se dar quanto a bens móveis. Essa alienação antecipada não é regra e, somente quando presentes tais pressupostos, em especial

\footnotetext{
${ }^{151}$ Neste sentido WAMBIER, Teresa Arruda Alvim; et al. Primeiros comentários ao novo código de processo civil: artigo por artigo. São Paulo: Editora Revista dos Tribunais, 2015, p. 1172.
} 
a vantagem que deve ser percebida por ambas as partes, é que se permite a inversão de procedimento $^{152}$. O produto da venda permanece nos autos até que seja autorizado seu levantamento para satisfação da obrigação.

Foram mantidas, também as duas modalidades de alienação já previstas na atual codificação e agora elencadas no artigo 879 do NCPC: a alienação por iniciativa particular ou por leilão judicial eletrônico ou presencial, preferindo-se a primeira em detrimento da segunda ${ }^{153}$.

O artigo 880 cuida da alienação por iniciativa particular, que acrescenta o leiloeiro público ao rol de legitimados para conduzi-la, mantidos o próprio exequente e o corretor credenciado - este último, hipótese de desjudicialização incidental, tal como destacado no item sobre a antiga codificação.

Quanto aos corretores, o mesmo dispositivo manteve a exigência de credenciamento destes profissionais perante os Tribunais, bem como a liberdade destes órgãos de regulamentarem esse credenciamento, sendo reduzido o período de experiência profissional exigido, de 5 para 3 anos $^{154}$.

Importante inovação introduzida neste mesmo artigo foi o poder conferido ao exequente de escolher livremente o corretor ou leiloeiro público nas comarcas em que não houver credenciados, de modo a não obstar a expropriação nesta modalidade ${ }^{155}$.

Se não consumada a alienação por iniciativa particular, a venda do bem se dá por leilão judicial, nos termos do artigo 881 do NCPC, realizado somente pelo mesmo leiloeiro público credenciado referenciado na alienação particular. Aqui, todavia, o juízo é quem designa o leiloeiro, cabendo ao exequente apenas indica-lo, nos termos do artigo $883^{156}$.

\footnotetext{
152 WAMBIER, Teresa Arruda Alvim; et al. Primeiros comentários ao novo código de processo civil: artigo por artigo. São Paulo: Editora Revista dos Tribunais, 2015, p. 1218.

${ }^{153}$ Ibidem, p. 1251.

${ }^{154}$ NEVES, Daniel Amorim Assumpção. Novo Código de Processo Civil - Lei 13.105/2015. 2 ed. São Paulo: Método, 2015. p. 449.

${ }^{155}$ Ibidem, p. 449.

${ }^{156}$ WAMBIER, Teresa Arruda Alvim; et al. Primeiros Comentários ao Novo Código de Processo Civil: artigo por artigo. 1ed. São Paulo: Revista dos Tribunais, 2015. p. 1254
} 
Importante inovação foi trazida pelo artigo 882, que estabeleceu o leilão judicial eletrônico como preferencial, sendo a subsidiária a modalidade presencial. No mais, os artigos 883 a 909 do NCPC, ainda que com algumas pequenas alterações, mantiveram, em essência, a mesma estrutura do leilão e das disposições acerca da satisfação do crédito preconizados na codificação atual.

\subsection{Aspectos relevantes do devido processo legal}

A execução, em se tratando de fenômeno coercitivo em sua essência, dada a expressa previsão do artigo $5^{\circ}$, inciso LIV da Constituição Federal da indispensabilidade de devido processo legal para privação de bens de qualquer pessoa, demanda um processo. Não se trata, pois, de qualquer processo.

Há de ser o processo devido, assim compreendido como aquele realizado em um estado ideal de protetividade de direitos ${ }^{157}$ e garantias delineados pelo texto constitucional, que assegure às partes o exercício pleno de suas faculdades e poderes processuais inerentes à ação e à defesa ${ }^{158} \mathrm{e}$ indispensáveis ao exercício da jurisdição ${ }^{159}$.

Assim, a seguir serão abordados, em linhas gerais, os mais importantes princípios e garantias que orientam o devido processo legal executivo brasileiro e que têm maior relevância para a análise de um modelo desjudicializado de execução por quantia, a ser desenvolvida no capítulo terceiro.

\footnotetext{
157 ÁVILA, Humberto. O que é “devido processo legal"? In: DIDIER JUNIOR, Fredie (coord.). Leituras complementares de Processo Civil. 8 ed. Salvador: Editora Juspodivm, 2010, p. 413; LUCON, Paulo Henrique dos Santos. Devido processo legal substancial. In: DIDIER JUNIOR, Fredie (coord.). Leituras complementares de Processo Civil. 8 ed. Salvador: Editora Juspodivm, 2010, p. 420.

158 POPP, Carlyle. A efetividade da tutela jurisdicional, a dignidade humana e a independência do juiz. In: GUNTHER, Luiz Eduardo (coord.). Jurisdição: crise, efetividade e plenitude institucional. Curitiba: Juruá, 2009, p. 102.

${ }^{159}$ GAIO JR., Antônio Pereira. Tutela específica das obrigações de fazer. Rio de Janeiro: Forense, 2000, p. 6.
} 


\subsubsection{Monopólio e inafastabilidade de jurisdição}

Conforme se destacou acima, a desjudicialização é fenômeno que se opera no âmbito da execução processualizada. Este processo não é senão a soma de atividades, poderes, faculdades, deveres, ônus e sujeições pelas quais o Estado exerce jurisdição ${ }^{160}$.

Jurisdição, por sua vez, nada mais é que uma expressão da soberania Estatal ${ }^{161}$ - e daí se dizer que ao Estado pertence o monopólio de jurisdição ${ }^{162}$ - que lhe confere autoridade para, diante de um conflito, decidir imperativamente e impor decisões ${ }^{163}$ com vistas à pacificação social e realização do direito material ${ }^{164}$.

É assim que o Estado-juiz, legitimado pela sua imparcialidade, substitui atividade das partes - o denominado caráter substitutivo da jurisdição ${ }^{165}$ - como forma de atingir o objetivo almejado pelo direito material.

Em que pese a noção de jurisdição ser frequentemente associada aos processos de conhecimento, na execução ela também se verifica. Chiovenda, inclusive, consigna que na execução é que ocorre, a rigor, a substituição ${ }^{166}$.

${ }^{160}$ DINAMARCO, Cândido Rangel. Execução civil. 8 ed. São Paulo: Malheiros, 2002, p. 194.

161. Neste sentido e classificando a jurisdição como uma das funções da soberania, ao lado das funções legislativa e administrativa: PICARDI, Nicola. Jurisdição e processo. Rio de Janeiro: Forense, 2008, p. 29; CHIOVENDA, Giuseppe Instituições de Direito Processual Civil. 4 ed. Campinas: Bookseller, 2009, p. 512. 162 SILVA, José Afonso da. Curso de Direito Constitucional positivo. 23 ed. São Paulo: Malheiros, 2004, p. 552.

${ }^{163}$ DINAMARCO, Cândido Rangel. Execução civil. 8 ed. São Paulo: Malheiros, 2002, p.190.

${ }^{164} \mathrm{O}$ conceito empregado advém da construção feita por Cândido Rangel Dinamarco e desenvolvida pelo autor, Ada Pellegrini Grinover e Antonio Carlos de Araújo Cintra na obra Teoria Geral do Processo (29 ed. São Paulo: Malheiros, 201, p. 155-183) a partir dos entendimentos de, principalmente, Giuseppe Chiovenda e Francesco Carnelutti. Para Chiovenda, jurisdição consiste na atuação da vontade concreta da lei por meio de substituição a cargo do Estado (Instituições de Direito Processual Civil. 4 ed. Campinas: Bookseller, 2009, p. 511). Já Carnelutti dá enfoque finalístico ao conceito, registrando que a jurisdição almeja a composição ou prevenção da lide (Instituições do Processo Civil - Volume I. São Paulo: Classic Book, 2000, p. 143). Aqui, nos atendo ao escopo do trabalho e dadas as grandes dimensões do debate acerca do conceito de jurisdição, será adotada a concepção do autor brasileiro, uma vez que congrega os principais entendimentos e tem ampla aceitação na doutrina nacional.

165 DINAMARCO, Cândido Rangel. Execução civil. 8 ed. São Paulo: Malheiros, 2002, p.196.

${ }^{166}$ CHIOVENDA, Giuseppe. Instituições de Direito Processual Civil. 4 ed. Campinas: Bookseller, 2009, p. 523. 
A diferença, assevera Carnelutti, se opera apenas no plano da "qualidade da lide": enquanto no processo de conhecimento há pretensão discutida - a ser sanada pela emissão de um juízo que soluciona a lide -, na execução há pretensão insatisfeita - a ser sanada por medidas que operam modificações fáticas ${ }^{167}$. Tal fato, contudo, não elide a característica jurisdicional da execução.

Afinal, não é outra a constatação quando o Estado-juiz, com imparcialidade e visando a pacificação social, atua em substituição ao devedor para adimplir com a obrigação e, assim, atingir o objetivo fixado pelo direito material.

Mesmo que a execução não se opere em substituição ${ }^{168}$, como nos casos de execução indireta, ainda assim há atuação do imperium, corolário direto da soberania estatal ${ }^{169}$, a coagir o devedor a cumprir o comando jurídico que o obriga a adimplir com a prestação.

Além disso, a orientação dos atos materiais da execução implica ao juiz a tomada de decisões, desde o recebimento da inicial executiva até a extinção do feito, passando pela ponderação quanto ao meio executivo empregado, de modo que sempre se faz presente o exercício da jurisdição ${ }^{170}$.

Ainda, a elidir qualquer dúvida a respeito da característica jurisdicional da execução, há de se considerar que a finalidade almejada pela jurisdição não é outra senão a observância prática do direito e, neste escopo, fazê-lo pelo não só pelo reconhecimento - processo ou

${ }^{167}$ CARNELUTTI, Francesco. Instituições do Processo Civil - Volume I. São Paulo: Classic Book, 2000, p. 126.

168 Pela substitutividade como elemento dissociável da ideia de jurisdição, CHIOVENDA, Instituições de Direito Processual Civil. 4 ed. Campinas: Bookseller, 2009, p. 522; NEVES, Daniel Amorim Assumpção. Manual de direito processual civil. 3 ed. São Paulo: Método, 2012, p. 12; CALAMANDREI, Piero. Direito Processual Civil-volume I. Campinas: Bookseller, 1999, p. 146.

169 ASSIS, Araken. Manual da execução. 14 ed. São Paulo: Editora Revista dos Tribunais, 2012, p. 126; DINAMARCO, Cândido Rangel. Instrumentalidade do processo. 11 ed. São Paulo: Malheiros, 2003, p. 115. ${ }^{170}$ DINAMARCO, Cândido Rangel. Instrumentalidade do processo. 11 ed. São Paulo: Malheiros, 2003, p. 311. 
fase de conhecimento - e, também, se necessário, por medidas que imponham o direito não cumprido voluntariamente e ofereçam o próprio resultado concreto do processo ${ }^{171}$

Estas evidências acabaram por pacificar a doutrina nacional acerca do caráter jurisdicional da execução, sendo raros e, em geral, anacrônicos os posicionamentos divergentes ${ }^{172}$.

Finalmente, não se olvide que, em um Estado Democrático de Direito, esta jurisdição deve ser acessível a todos, de forma ampla e irrestrita. Qualquer lesão ou ameaça de lesão a direito deve ter caminho livre para ser levada a exame e solução perante o Estado-juiz presente no Poder Judiciário, ao que se denominou princípio da inafastabilidade de jurisdição ${ }^{173}$.

Este princípio, insculpido no artigo $5^{\circ}$, inciso XXXV da Constituição Federal, destina-se a todos, indistintamente, mas, principalmente, ao legislador ${ }^{174}$. Dentre outros desdobramentos, veda a jurisdição condicionada, de modo que, a menos que haja dispositivo

171 CALAMANDREI, Piero. Direito Processual Civil - volume I. Campinas: Bookseller, 1999, p. 137; LEONEL, Ricardo de Barros. Tutela jurisdicional diferenciada no Projeto de Novo Código de Processo Civil. Revista de Informação Legislativa, v. 190, p. 179-190, 2011, p. 181; SAMPAIO, J.M. Gonçalves. A acção executiva e a problemática das execuções injustas. 2 ed. Coimbra: Edições Almedina, 2008, p. 447-448. Todos a corroborar o clássico entendimento de Giuseppe Chiovenda de que "o processo deve dar, quanto for possível praticamente, a quem tenha um direito, tudo aquilo e exatamente aquilo que ele tenha direito de conseguir" (Instituições de Direito Processual Civil. 4 ed. Campinas: Bookseller, 2009, p. 87).

172 ASSIS, Araken. Manual da execução. 14 ed. São Paulo: Editora Revista dos Tribunais, 2012, p. 124; VIANA, Juvêncio Vasconcelos. Efetividade do processo: a execução em momentos distintos da reforma do CPC. In: LOPES, João Batista; CUNHA, Leonardo Carneiro da (coord.). Execução civil (aspectos polêmicos). São Paulo: Dialética, 2005, p. 221; BEDAQUE, Jose Roberto dos Santos. Cognição e decisões do juiz no processo executivo. In: FUX, Luiz; NERY JUNIOR, Nelson; WAMBIER, Tereza Arruda Alvim (coord.). Processo e constituição: estudos em homenagem ao professor José Carlos Barbosa Moreira. São Paulo: Editora Revista dos Tribunais, 2006, p. 374; BAUMÖHL, Debora Ines Kram. A nova execução civil: a desestruturação do processo de execução. São Paulo: Atlas, 2006, p. 24.

173 GRINOVER, Ada Pellegrini. A inafastabilidade do controle jurisdicional e uma nova modalidade de autotutela. Revista Brasileira de Direito Constitucional, $\mathrm{n}^{\mathrm{o}}$ 10, jul.-dez. 2007. Disponível em: <http://www.esdc.com.br/RBDC/RBDC-10/RBDC-10-013-Ada_Pellegrini_Grinover.pdf〉. Acesso em 23 mar. 2015, p. 13.

${ }^{174}$ NERY JUNIOR, Nelson. Princípios do processo civil na Constituição Federal. 9 ed. São Paulo: Revista dos Tribunais, 2009, p. 170. 
constitucional em sentido diverso, é sempre garantido o acesso livre e direto ao poder jurisdicional do Estado ${ }^{175}$.

Logo, no atual procedimento, o credor que atende aos pressupostos e condições da ação executiva, terá garantido o direito de movê-la perante o Poder Judiciário, postulando a tutela jurisdicional plena, com a satisfação de seu direito material no plano fático ${ }^{176}$.

De igual modo, o devedor que tiver direito seu indevidamente violado ou ameaçado por execução que lhe é movida, deve ter livre acesso ao Poder Judiciário para que lhe seja oferecida a correlata tutela jurisdicional.

\subsubsection{Imparcialidade e naturalidade do juiz e dos auxiliares}

O Estado, enquanto detentor do monopólio de jurisdição, uma vez submetido à inafastabilidade jurisdicional, quer seja de conhecimento, quer seja, executiva, deve prestála de forma equânime às partes. Trata-se da aplicação, ao processo, do princípio da igualdade, consagrado no artigo $3^{\circ}$, inciso IV e artigo $5^{\circ}$, caput, ambos da Constituição Federal $^{177}$.

Esta igualdade, no processo, é afetada por meio da legislação - que deve promover em abstrato a equalização das partes perante o juízo - e da atuação dos agentes diante da relação jurídica processual. Quanto a esta última, a igualdade se opera, principalmente, por meio da imparcialidade do juiz, forma qualificada do princípio da impessoalidade a que está submetida toda a administração pública, por força do artigo 37, caput, da Constituição Federal.

\footnotetext{
${ }^{175}$ LENZA, Pedro. Direito constitucional esquematizado. 17 ed. São Paulo: Saraiva, 2013, p. 1075.

176 SICA, Heitor Vitor Mendonça. O direito de defesa no Processo Civil brasileiro. São Paulo: Atlas, 2011, p. 38.

177 DINAMARCO, Cândido Rangel. Instituições de Direito Processual Civil - Volume I. 7 ed. São Paulo: Malheiros, 2013, p. 213.
} 
A impessoalidade é um desdobramento da isonomia que veda a atuação dos agentes públicos em função de seus interesses pessoais em detrimento do interesse público do Estado $^{178}$. São defesos, portanto, tratamentos discriminatórios, de favorecimento ou detrimento a qualquer pessoa que se relacione com a administração. Deste princípio decorrem previsões como as exigências de concurso público para exercício de cargo, emprego ou função pública e a de licitação para as contratações públicas ${ }^{179}$.

Já a imparcialidade é conceito análogo, que compreende uma série de garantias cujo objetivo principal é viabilizar que o Estado-juiz, no exercício de sua função jurisdicional, atue com indiferença inicial quanto à disputa e às pessoas nela envolvidas ${ }^{180}$, como um terceiro estranho, equidistante dos interessados ${ }^{181}$ e independente em relação ao caso concreto $^{182}$.

Dentre estas garantias ${ }^{183}$, merecem destaque, porquanto relevantes ao escopo do trabalho, a independência do Poder Judiciário e a de seus magistrados e o princípio do juiz natural.

A primeira delas, independência do Poder Judiciário e seus magistrados, é pressuposto inexorável da imparcialidade, pois tem o fito de afastar eventuais amarras

\footnotetext{
${ }^{178}$ DINAMARCO, Cândido Rangel. Instituições de Direito Processual Civil - Volume I. 7 ed. São Paulo: Malheiros, 2013, p. 335.

${ }^{179}$ MELLO, Celso Antônio Bandeira de. Curso de Direito Administrativo. São Paulo: Malheiros, 2010, p. 110 ${ }^{180}$ DINAMARCO, Cândido Rangel. Instituições de Direito Processual Civil - Volume I. 7 ed. São Paulo: Malheiros, 2013, p. 206.

${ }^{181}$ THEODORO JUNIOR, Humberto. Curso de direito processual civil. 47 ed. Rio de Janeiro: Forense, 2007, p. 41.

${ }^{182}$ WAMBIER, Luiz Rodrigues; TALAMINI, Eduardo. Curso avançado de Processo Civil - Volume 1. 13 ed. São Paulo: Editora Revista dos Tribunais, 2013, p. 96.

${ }^{183}$ Cândido Rangel Dinamarco lista como garantias de imparcialidade, além dos aspectos citados no texto, as hipóteses de suspeição e impedimento por meio das quais é possível o afastamento do juiz que tenha relação com a causa e o princípio da demanda, que impõe ao juiz a inércia até que as partes movimentem o feito (Instituições de Direito Processual Civil - Volume I. 7 ed. São Paulo: Malheiros, 2013, p. 205-207).
} 
externas que possam condicionar a prestação jurisdicional ${ }^{184}$. Se revela, principalmente, nas prerrogativas institucionais do primeiro e funcionais do segundo.

A Constituição Federal, em seu artigo 99, garante ao Poder Judiciário seu autogoverno por meio de suas autonomias administrativa e orçamentária, o que não exclui sua interação com os demais Poderes, regulamentada no próprio texto constitucional em diversos dispositivos, casos, por exemplo, do artigo 93 - que prevê a edição de Lei Complementar de iniciativa do próprio Supremo Tribunal Federal para definir o Estatuto da Magistratura - e do artigo 94, parágrafo único - que prevê a seleção prévia, pelos Tribunais, de uma lista tríplice, para que então o chefe do Executivo escolha um membro integrante do quinto constitucional - ambos do mencionado diploma legal.

O tratamento dado pela Constituição, de um lado, evidencia a relativização da garantia de autogoverno do Judiciário e, de outro, traça limites de intervenção entre os Poderes - sistema de freios e contrapesos -, de modo a restarem vedadas outras intervenções que excedam estas hipóteses ${ }^{185}$. Desse modo, o exercício da função jurisdicional estaria incólume, constitucionalmente blindado de quaisquer intervenções que afetem a imparcialidade que atrela o juiz às partes, estando a atuação jurisdicional sujeita a controle apenas da própria jurisdição ${ }^{186}$.

Não bastasse o isolamento do Poder Judiciário, aos seus membros são conferidas garantias que permitem que exerçam a função jurisdicional com maior segurança e com menores sujeições a fatores externos. São os casos da vitaliciedade, inamovibilidade e

\footnotetext{
184 PAMPLONA FILHO, Rodolfo; BARBOSA, Charles. Reflexões filosóficas sobre a neutralidade e imparcialidade no ato de julgar e o Projeto do Novo Código de Processo Civil. In: DIDIER JUNIOR, Fredie; ADONIAS, Antonio (coord.). Projeto do novo código de processo civil $-2^{a}$ série. Salvador: Editora Juspodivm, 2012, p. 658.

185 DINAMARCO, Cândido Rangel. Instituições de Direito Processual Civil - Volume I. 7 ed. São Paulo: Malheiros, 2013, p. 372.

186 DIDIER JUNIOR, Fredie. Curso de direito processual civil - Volume 1. 14 ed. Salvador: Editora Juspodivm, 2012, p. 103. Parte da doutrina trata do tema sob a alcunha de imutabilidade da jurisdição. Neste sentido, por todos, WAMBIER, Luiz Rodrigues; TALAMINI, Eduardo. Curso avançado de Processo Civil Volume 1. 13 ed. São Paulo: Editora Revista dos Tribunais, 2013, p. 96-97.
} 
irredutibilidade de subsídios, bem como a definição, já nos regramentos dos artigos 93 e 94 da Constituição Federal, dos critérios para ingresso e promoção na carreira da magistratura $^{187}$, todos aspectos inerentes à investidura na autoridade judicial. Ainda vedações como as de acumulação de cargos e de recebimento de custas ou participação em processos, expressas no parágrafo único do artigo 95 da Constituição Federal, compõem a independência e imparcialidade da magistratura.

A projeção externa da imparcialidade no exercício da jurisdição se dá pela garantia do juiz natural, que assegura às partes o direito de serem julgadas por juízes instituídos conforme a Constituição e competentes segundo a lei, conforme preconiza o artigo $5^{\circ}$, inciso LII da Constituição Federal, vedando-se, ainda, tribunais de exceção criados pelo legislador ordinário de forma diversa daquela prevista na Carta Maior ${ }^{188}$, nos termos de seu artigo $5^{\circ}$, inciso XXXVII.

A doutrina extrai do conceito de juiz natural algumas características essenciais ${ }^{189}$, dentre as quais a mais relevante para o escopo do trabalho é o julgamento por juiz prévia e devidamente investido na função, conforme regras de competência previamente estabelecidas $^{190}$, aleatoriamente designado para o caso por um mecanismo interno ao Poder Judiciário para a individualização do juízo ${ }^{191}$.

Estes aspectos destacados até aqui, cujos opostos se conformam na noção de tribunal de exceção supracitada, atuam como meio de implementação das garantias de imparcialidade

187 DINAMARCO, Cândido Rangel Instituições de Direito Processual Civil - Volume I. 7 ed. São Paulo: Malheiros, 2013, p. 207.

188 THEODORO JUNIOR, Humberto. Curso de direito processual civil. 47 ed, Rio de Janeiro: Forense, 2007, p. 42.

189 Além da característica destacada no texto, a doutrina aponta ainda a preexistência do órgão judiciário e a presença de juiz competente (DINAMARCO, Cândido Rangel. Instituições de Direito Processual Civil Volume I. 7 ed. São Paulo: Malheiros, 2013, p. 208-213; DIDIER JUNIOR, Fredie. Curso de direito processual civil - Volume 1. 14 ed. Salvador: Editora Juspodivm, 2012, p. 121-123).

${ }^{190}$ NEVES, Daniel Amorim Assumpção Manual de direito processual civil. 3 ed. São Paulo: Método, 2012, p. 25.

${ }^{191}$ PICARDI, Nicola. Il giudice naturale principio fondamentale a livello europeo. In: DIDIER JUNIOR, Fredie (coord.). Teoria do processo: panorama doutrinário mundial - Volume 2. Salvador: Editora Juspodivm, 2010, p. 691. 
supracitadas. Por meio deles é possível extrair, ainda, a garantia de indelegabilidade da função jurisdicional, pela qual é vedado que um órgão jurisdicional delegue seu poder decisório para outro órgão ${ }^{192}$.

Conforme se destacou no item em que foi tratado o procedimento de execução por quantia do atual Código de Processo Civil, o dever de imparcialidade se estende também aos auxiliares da justiça ${ }^{\mathbf{1 9 3}}$, que respondem pela lisura no exercício das respectivas funções públicas das quais são encarregados ${ }^{194}$.

Estes profissionais, porém, por não exercerem a atividade jurisdicional propriamente dita e por estarem subordinados ao cumprimento de determinações do juiz, não usufruem da mesma estrutura voltada à imparcialidade criada aos magistrados. Em verdade, diferentemente do que ocorre com estes últimos, não há uma estrutura que vise, especificamente, garantir a imparcialidade destes agentes no exercício de suas funções, mas sim estruturas, em geral inatas ao tipo de investidura destes agentes, que, incidentalmente, contribuem para o preceito.

Os auxiliares permanentes da Justiça, que integram os quadros do Poder Judiciário, em que pese serem investidos nos cargos por meio de concurso público, terem suas atividades regulamentadas em lei, serem remunerados pelo Estado e sujeitos a todos os direitos e deveres dos agentes públicos, não gozam de inamovibilidade - podem ser removidos de oficio do local onde exercem suas atribuições - ou vitaliciedade - podem ser exonerados após processo meramente administrativo -, por exemplo. Também o princípio do juiz natural a eles se aplica apenas de forma reflexa, haja vista que atuam vinculados e subordinados ao respectivo juízo ou tribunal, este sim, submetido às exigências do princípio.

Já os auxiliares eventuais do juízo, que não integram o quadro funcional do Poder Judiciário e são os principais agentes das desjudicializações incidentais já existentes no atual

192 DIDIER JUNIOR, Fredie. Curso de direito processual civil - Volume 1. 14 ed. Salvador: Editora Juspodivm, 2012, p. 115.

193 TARZIA, Giuseppe. Il giusto processo di esecuzione. Rivista di Diritto Processuale, ano LVII, n. 2, abriljunho 2002, p. 338.

${ }^{194}$ DINAMARCO, Cândido Rangel. Instituições de Direito Processual Civil - Volume I. 7 ed. São Paulo: Malheiros, 2013, p.667. 
procedimento de execução por quantia, como visto acima, em que pese também terem um dever geral de imparcialidade e respeito aos princípios administrativos decorrentes da função exercida, atuam com ainda menos mecanismos voltados à garantia do preceito.

Não são beneficiados diretamente pelo autogoverno do Poder Judiciário - pertencem, em regra, à iniciativa privada -, não possuem qualquer das garantias elencadas aos juízes ou aos auxiliares permanentes, são remunerados pelas partes conforme o valor fixado pelo juízo e suas seleções ficam ao arbítrio de cada Tribunal. Este último aspecto faz com que os efeitos do juiz natural, aqui, sejam ainda menos sensíveis, haja vista que a designação destes profissionais pode assumir diversas formas, com diferentes propósitos, desde as mais democráticas, voltadas ao rodízio dos profissionais, até as mais arbitrárias, voltadas à conveniência do juízo e efetividade processual.

O principal mecanismo à disposição destes profissionais é o direito de recusa, de não aceitar a designação que não lhe interessar, independentemente do motivo, aí incluídas, portanto, as hipóteses em que julgar afetada sua imparcialidade. Porém, a exemplo do que se passa com as garantias dos auxiliares permanentes, o benefício à imparcialidade não é direto, mas sim mero reflexo de recurso criado com finalidades mais amplas e que, oportunamente, socorrem ao dever geral de imparcialidade destes agentes.

Independentemente do agente, os comprometimentos à imparcialidade são passíveis de alegação de suspeição ou impedimento pelos interessados durante o processo, tal como preconizado pelos artigos 134 a 138 do Código de Processo Civil. No Novo Código de Processo Civil, aliás, o artigo 148, que vem em substituição ao atual artigo 138, estendeu a possibilidade de alegação de impedimento ou suspeição a todo e qualquer auxiliar da justiça, indistintamente, bem como a todo e qualquer sujeito sobre o qual recaia dever de imparcialidade no processo.

\subsubsection{Contraditório e ampla defesa}

Se, no processo, o princípio isonômico se opera, quanto ao juiz, principalmente por meio de sua imparcialidade e naturalidade, quanto às partes ele se configura notadamente por meio do contraditório e da ampla defesa, meios pelos quais se caracteriza a regularidade 
dos juízos ${ }^{195}$. É também por meio do contraditório e ampla defesa que o exercício do poder jurisdicional presta contas aos litigantes ${ }^{196}$, conformando, no processo, a participação democrática dos cidadãos na atuação do Estado ${ }^{197}$.

Ambos têm previsão no artigo $5^{\circ}$, inciso LV da Constituição Federal, cujo texto legal preconiza que os litigantes e acusados em geral têm direito de exercer o contraditório e ampla defesa em processos judiciais e administrativos.

Considerando que a noção de ampla defesa está contida na de contraditório ${ }^{198}$, a análise deste último é que ganha relevo na doutrina. O princípio do contraditório é usualmente analisado sob duas dimensões: formal e material. A vertente formal se estabelece pela conjugação de dois elementos, a informação e possibilidade de reação, os quais confluem num mesmo objetivo, qual seja, o de evitar surpresa às partes ${ }^{199}$.

A informação se perfaz na necessidade de a parte ser cientificada dos atos processuais para que possa se posicionar a este respeito, o que se dá, principalmente, por meio dos atos de intimação e citação ${ }^{200}$.

Já a reação, quando a contenda versa sobre direitos disponíveis - caso das execuções por quantia, em geral -, consiste na oportunização de reação, apenas. Não é necessário que ela ocorra de fato, mas sim que à parte seja conferida a possibilidade de agir e participar da defesa de seus interesses ${ }^{201}$

\footnotetext{
${ }^{195}$ CARVALHO, Milton Paulo de. Os princípios e um novo código de processo civil. In: CARNEIRO, Athos Gusmão; CALMON, Petrônio (org.). Bases científicas para um renovado direito processual. 2 ed. Salvador: Juspodivm, 2009, p. 211

${ }^{196}$ MARINONI, Luiz Guilherme. Curso de Processo Civil - Volume 1. 7 ed. São Paulo: Editora Revista dos Tribunais, 2013, p. 415.

197 GRECO, Leonardo. O processo de execução: volume I. Rio de Janeiro: Renovar, 1999, p. 267.

198 DIDIER JUNIOR, Fredie. Curso de direito processual civil - Volume 1. 14 ed. Salvador: Editora Juspodivm, 2012, p. 61.

199 GAJARDONI, Fernando da Fonseca. Flexibilização procedimental: um novo enfoque para o estudo do procedimento em matéria processual. São Paulo: Atlas, 2008, p. 89.

${ }^{200}$ NEVES, Daniel Amorim Assumpção. Manual de direito processual civil. 3 ed. São Paulo: Método, 2012, p. 64.

${ }^{201}$ Ibidem, p. 65.
} 
Ambos os elementos têm como objetivo último garantir a não-surpresa, ou seja, garantir que a prestação jurisdicional, enquanto manifestação de um estado democrático, não cause surpresa às partes, devendo ser produto de prévia discussão entre os sujeitos da relação processual $^{202}$. Não pode o juiz, de ofício, levar em consideração um fato do qual não se oportunizou manifestação das partes ${ }^{203}$.

É neste sentido que a dimensão material do princípio do contraditório inclui, além dos aspectos contemplados no contraditório formal, a garantia de que eventual reação das partes se dê em paridade de $\operatorname{armas}^{204}$, de modo que cada uma tenha real poder de influenciar na formação do convencimento do magistrado, não se limitando a texto normativo, mas sim tendo aptidão para carregar razões fáticas e jurídicas ao convencimento do juiz ${ }^{205}$.

O contraditório, tal como se dá com qualquer direito fundamental, pode ser objeto de relativização. Dada a sua especificidade de, em regra, se apresentar como a antítese do objeto veiculado na ação, esta relativização normalmente se opera em privilégio da efetividade do direito material almejado ${ }^{206}$.

É neste sentido que, na execução, em se tratando de relação processual "menos triangular do que angular", com maior serenidade à atuação da sanção executiva ${ }^{207}$, o

202 NEVES, Daniel Amorim Assumpção. Manual de direito processual civil. 3 ed. São Paulo: Método, 2012, p. 67.

${ }^{203}$ DIDIER JUNIOR, Fredie. Curso de direito processual civil - Volume 1. 14 ed. Salvador: Editora Juspodivm, 2012, p. 59.

${ }^{204}$ Luiz Guilherme Marinoni esclarece que a paridade de armas não consiste apenas em garantir que ambas as partes atuem com igualdade de poderes, mas sim que tais poderes tenham fundamento na necessidade de igualar as forças de ambas conforme suas respectivas necessidades (Curso de Processo Civil - Volume 1. 7 ed. São Paulo: Editora Revista dos Tribunais, 2013, p. 418-422), tratando-se, pois, como afirmado, da aplicação, às partes, do princípio da isonomia.

205 DIDIER JUNIOR, Fredie. Curso de direito processual civil - Volume 1. 14 ed. Salvador: Editora Juspodivm, 2012, p. 57; NEVES, Daniel Amorim Assumpção. Manual de direito processual civil. 3 ed. São Paulo: Método, 2012, p. 65.

${ }^{206}$ MARINONI, Luiz Guilherme. Curso de Processo Civil - Volume 1. 7 ed. São Paulo: Editora Revista dos Tribunais, 2013, p. 341.

207 TARZIA, Giuseppe. O contraditório no processo executivo. Revista de processo, no 28 , ano 7, out.-dez. 1982, p. 84. 
princípio do contraditório atua, porém de forma distinta ${ }^{208}$. Isto porque, diferentemente da função de conhecimento, em que preponderam as alegações das partes e a intelecção do órgão jurisdicional em busca de um juízo de certeza ${ }^{209}$, na execução parte-se da certeza ${ }^{210}$ ou da "probabilidade séria" 211 - para que prevaleçam as transformações fáticas que visem satisfazer o credor ${ }^{212}$.

Assim, aqui, em lugar de o requerido ser provocado para que se defenda - como se dá no processo ou fase de cognição -, em regra é ele quem provoca o requerente acerca de determinado ponto controvertido, a exemplo do que se observa nos artigos 655-A, §2, 656 , $\S 3^{\circ}$ e 668 , todos do Código de Processo Civil, em inversão do ônus de se provocar o contraditório $^{213}$. Pode-se dizer, portanto, que o exercício do contraditório na execução, via

${ }^{208}$ Há alguma divergência doutrinária, ainda que um tanto obsoleta, acerca da existência de contraditório na execução. Há quem defenda a inexistência de contraditório (LIEBMAN, Enrico Tullio. Processo de execução. 5 ed. São Paulo: Saraiva, 1986, p. 44), a sua mitigação (TARZIA, Giuseppe. Il giusto processo di esecuzione. Rivista di Diritto Processuale, ano LVII, n. 2, abril-junho 2002, p. 335; BEDAQUE, Jose Roberto dos Santos. Cognição e decisões do juiz no processo executivo. In: FUX, Luiz; NERY JUNIOR, Nelson; WAMBIER, Tereza Arruda Alvim (coord.). Processo e constituição: estudos em homenagem ao professor José Carlos Barbosa Moreira. São Paulo: Editora Revista dos Tribunais, 2006, p. 374; CARVALHO, Milton Paulo de. Os princípios e um novo código de processo civil. In: CARNEIRO, Athos Gusmão; CALMON, Petrônio (org.). Bases científicas para um renovado direito processual. 2 ed. Salvador: Juspodivm, 2009, p. 212; BAUMÖHL, Debora Ines Kram. A nova execução civil: a desestruturação do processo de execução. São Paulo: Atlas, 2006, p. 65) ou sua existência absoluta (WAMBIER, Luiz Rodrigues; TALAMINI, Eduardo. Curso avançado de Processo Civil - Volume 2. 13 ed. São Paulo: Editora Revista dos Tribunais, 2013, p. 178; GRECO, Leonardo. O processo de execução: volume I. Rio de Janeiro: Renovar, 1999, p. 268; GUERRA, Marcelo Lima. Execução forçada: controle de admissibilidade. 2 ed. São Paulo: Editora Revista dos Tribunais, 1998, p. 30). Contudo, curiosamente, os autores reconhecem, em essência, as mesmas peculiaridades, de limitações quanto ao objeto de exercício do contraditório em razão do objeto da execução, apenas justificando-as conforme a terminologia empregada, o que implica concluir que a controvérsia não tem grandes repercussões práticas. Não sendo necessários maiores aprofundamentos quanto ao princípio do contraditório, tendo em conta o objeto do trabalho, basta a posição adotada praticamente pela unanimidade da doutrina e explanada no texto, de que há contraditório na execução, com algumas ressalvas.

${ }^{209}$ SILVA, Ovídio Araújo Baptista da. Jurisdição e execução na tradição romano-canônica. 2 ed. São Paulo: Editora Revista dos Tribunais, 1997, p. 117.

${ }^{210}$ MOREIRA, Alberto Camiña. Defesa sem embargos do executado: exceção de pré-executividade. 2 ed. São Paulo: Saraiva, 2000, p. 3.

211 SAMPAIO, J.M. Gonçalves. A acção executiva e a problemática das execuções injustas. 2 ed. Coimbra: Edições Almedina, 2008, p. 450.

212 ASSIS, Araken de. Cumprimento de Sentença. 4 ed. Rio de Janeiro: Forense, 2013, p. 12.

${ }^{213}$ DIDIER JUNIOR, Fredie; BRAGA, Paula Sarno; OLIVEIRA, Rafael; CUNHA, Leonardo José Carneiro da. Curso de direito processual civil - Execução - Volume 5. 4 ed. Salvador: Editora Juspodivm, 2012, p. 55. 
de regra, dependerá de respostas do devedor aos comandos judiciais tendentes à satisfação do título executivo ${ }^{214}$.

Estas respostas aos comandos judiciais se dão de duas formas. No próprio rito executivo, elas se apresentam, de forma geral, em incidentes cognitivos destinados a preparar, possibilitar ou dimensionar a entrega do bem ao exequente por meio da tutela jurisdicional executiva ${ }^{215}$. É o que se observa nos pedidos de suspensão e extinção do processo, nas alegações de fraude à execução, nas hipóteses em que se faz necessário garantir a observância do princípio do menor sacrifício ao devedor ${ }^{216}$ - como eventual impenhorabilidade de um bem - ou para suscitar questões cognoscíveis de ofício pelo juiz, casos dos pressupostos processuais e condições da ação ${ }^{217}$.

Para além do rito executivo, é possível que se exerça o contraditório pelos meios típicos de defesa, quer seja por incidente processual - impugnação ao cumprimento de sentença - quer seja por ação autônoma - embargos do executado ${ }^{218}$ - ocasiões em que as matérias passíveis de discussão são mais amplas do que aquelas facultadas durante o próprio rito executivo. Nestes casos, a depender da vulnerabilidade do título executivo - maior nos títulos extrajudiciais -, a discussão pode avançar até a gênese do direito material

${ }^{214}$ CARVALHO, Milton Paulo de. Os princípios e um novo código de processo civil. In: CARNEIRO, Athos Gusmão; CALMON, Petrônio (org.). Bases científicas para um renovado direito processual. 2 ed. Salvador: Juspodivm, 2009, p. 212.

215 DINAMARCO, Cândido Rangel. Instituições de Direito Processual Civil - Volume IV. 3 ed. São Paulo: Malheiros, 2009, p. 72.

216 Trata-se de princípio da execução pelo qual a satisfação da obrigação deve se dar pelo meio que se se revelar menos oneroso ao devedor (WAMBIER, Luiz Rodrigues. Anotações sobre a crise do Processo de Execução Algumas sugestões voltadas à sua efetividade. In: DIDIER JR., Fredie (coord.). Execução civil: estudos em homenagem ao professor Paulo Furtado. Rio de Janeiro: Editora Lumen Juris, 2006, p. 251)

217 WAMBIER, Luiz Rodrigues; TALAMINI, Eduardo. Curso avançado de Processo Civil - Volume 2. 13 ed. São Paulo: Editora Revista dos Tribunais, 2013, p. 178; DIDIER JUNIOR, Fredie; BRAGA, Paula Sarno; OLIVEIRA, Rafael; CUNHA, Leonardo José Carneiro da. Curso de direito processual civil - Execução Volume 5.4 ed. Salvador: Editora Juspodivm, 2012, p. 54

${ }^{218}$ CÂMARA, Alexandre. Lições de Direito Processual Civil - Volume II. 20 ed., Rio de Janeiro: Lumen Juris, 2012, p. 157; DIDIER JUNIOR, Fredie; BRAGA, Paula Sarno; OLIVEIRA, Rafael; CUNHA, Leonardo José Carneiro da. Curso de direito processual civil - Execução - Volume 5.4 ed. Salvador: Editora Juspodivm, 2012, p. 54. 
controvertido $^{219}$, conformando-se o contraditório tal como nos processos ou fases de conhecimento.

Tais peculiaridades são inerentes à condição desfavorável em que o executadodevedor se encontra em relação ao exequente-credor já no campo do direito material. Porém, as diferenciações feitas no campo processual vão ao encontro do fim almejado pelo princípio da isonomia, no sentido de conformar paridade de armas entre as partes que se apresentam em condições distintas ${ }^{220}$.

\subsubsection{A razoável duração do processo executivo}

A razoável duração do processo é corolário indissociável do devido processo legal, associação estabelecida já desde a Magna Carta ${ }^{221}$.

Trata-se de garantia que, no Brasil, desde a Emenda Constitucional $n^{\circ}$ 45/2004, consta no artigo $5^{\circ}$, inciso LXXVIII da Constituição Federal ${ }^{222}$. Referido dispositivo impõe que o processo deve demorar "o tempo necessário e adequado à solução do caso submetido ao órgão jurisdicional"223, sem dilações indevidas, ou seja, o tempo do processo deve ser utilizado de modo racional pelas partes e pelo Estado-juiz. Quando este uso racional do

219 JORGE, Flavio Cheim. Relação processual e contraditório nas diversas espécies de execução. In: DIDIER JR., Fredie (coord.). Execução civil: estudos em homenagem ao professor Paulo Furtado. Rio de Janeiro: Editora Lumen Juris, 2006, p. 104.

${ }^{220}$ BATISTA SANTOS, Guilherme Luis Quaresma. Contraditório e execução. Rio de Janeiro: Lumen Juris, 2013 , p. 49.

221 KOEHLER, Frederico Augusto Leopoldino. A razoável duração do processo. 2 ed. Salvador: Editora Juspodivm, 2013, p. 36.

${ }^{222}$ Pode-se considerar que a inserção do princípio no ordenamento brasileiro se deu antes, com a vigência do Decreto n ${ }^{\circ}$ 678/92, que ratificou o Pacto de San Jose da Costa Rica, cujo artigo $8^{\circ}$ já prevê o direito de prazo razoável para que qualquer pessoa seja ouvida (NITSCHKE JÚNIOR, Ademar; PAVELSKI, Ana Paula. Razoável duração do processo e responsabilidade do Estado. In: GUNTHER, Luiz Eduardo (coord.). Jurisdição: crise, efetividade e plenitude institucional. Curitiba: Juruá, 2009, p. 25).

223 DIDIER JUNIOR, Fredie. Curso de direito processual civil - Volume 1. 14 ed. Salvador: Editora Juspodivm, 2012, p. 69. 
tempo não ocorre e o processo se torna moroso, fugindo à sua duração razoável, deixa-se de ter um processo devido.

A despeito da dificuldade de se definir, em abstrato, o que seria uma "utilização racional", uma vez que o tempo necessário a cada processo é variável conforme o direito em litígio e o caso concreto, o diagnóstico pode ser feito por exclusão, ou seja, identificando-se as ocasiões em que o tempo do processo foge à razoabilidade. É o que ocorre, por exemplo, nas ditas “etapas mortas" do processo, lapsos temporais sem qualquer atividade ou respaldo jurídico, que separam a realização de atos processuais e que decorrem, em regra, da inércia do órgão jurisdicional ${ }^{224}$, e que não têm razão de ser senão como vício da razoável duração do processo.

Em situações tais, em que o uso racional do processo não se verifica, busca-se a celeridade como meio de se equilibrar o tempo do processo. Neste cenário, a segurança jurídica surge como contrapeso. É ela quem limita as medidas adotadas para conferir celeridade ao processo, já que esta não é um fim em si mesma 225 .

A razoável duração do processo se ancora, então, em dois valores básicos, que devem atuar sempre em equilíbrio: a celeridade e a segurança jurídica ${ }^{226}$. Não há de se buscar um processo seguro, porém demasiadamente lento ${ }^{227}$, tampouco um processo rápido "a qualquer preço" 228 , incapaz de garantir um mínimo de segurança jurídica ${ }^{229}$.

\footnotetext{
${ }^{224}$ CRUZ E TUCCI, José Rogério. Garantias constitucionais da duração razoável e da economia processual no projeto do CPC. Revista Magister de Direito Civil e Processual Civil, Porto Alegre, ano VIII, no 43, jul.-ago. 2011, p. 30.

${ }^{225}$ BESTER, Gisela Maria; HANS, Gabriela Damião Cavalli. As ações sincréticas como instrumento de celeridade processual: direitos fundamentais conexos e efetividade constitucional. In: GUNTHER, Luiz Eduardo (coord.). Jurisdição: crise, efetividade e plenitude institucional. Curitiba: Juruá, 2009, p. 234.

${ }^{226}$ BEDAQUE, José Roberto dos Santos. Efetividade do processo e técnica processual. 3 ed. São Paulo: Malheiros, 2010, p. 49.

${ }^{227}$ MARINONI, Luiz Guilherme. O direito à efetividade da tutela jurisdicional na perspectiva da teoria dos direitos fundamentais. Revista de Direito Processual Civil. Curitiba: Gênesis, 2003, p. 305.

${ }^{228}$ BARBOSA MOREIRA, José Carlos. O futuro da justiça: alguns mitos. Revista da Academia Brasileira de Letras Jurídicas, Rio de Janeiro, v. 17, jan.-dez. 2001, p. 157.

${ }^{229}$ BEDAQUE, José Roberto dos Santos. Efetividade do processo e técnica processual. 3 ed. São Paulo: Malheiros, 2010, p. 49.
} 
Problemas com a razoável duração do processo não são novos e tampouco exclusivos do Brasil $^{230}$, porém assumem maior importância hodiernamente ${ }^{231}$. Por aqui, a busca por um processo de duração razoável é, ao menos até o ano de 2020, figura central no planejamento estratégico do Poder Judiciário, elaborado quinquenalmente pelo Conselho Nacional de Justiça e de aplicação obrigatória a todos os segmentos de justiça ${ }^{232}$.

A solução passa pela adoção de mecanismos que permitam a gestão do volume crescente de demandas ${ }^{233}$. Com isso em vista, a doutrina nacional, já há algum tempo, tem estimulado a adoção de técnicas de aceleração do processo. Estas técnicas podem ser classificadas e divididas entre extraprocessuais - voltadas para o aparelhamento do Poder Judiciário -, judiciais - com vistas à aceleração do processo em si - e extrajudiciais - que buscam mecanismos alternativos ao Estado-juiz ${ }^{234}$.

Em qualquer delas, a aferição da segurança jurídica se dá por meio de análise da técnica empregada à luz, principalmente, das garantias enunciadas até aqui: monopólio e inafastabilidade da jurisdição, imparcialidade e naturalidade do juiz e contraditório e ampla defesa. Sempre que se emprega uma técnica de aceleração do processo é necessário analisar a afetação destes elementos, de modo a se verificar a viabilidade de sua implementação.

\footnotetext{
${ }^{230}$ MANCUSO, Rodolfo de Camargo. A resolução dos conflitos e a função judicial no contemporâneo Estado de Direito. 2 ed. São Paulo: Editora Revista dos Tribunais, 2014, p. 161; LEBRE DE FREITAS, José. A reforma do processo executivo. Revista da Ordem dos Advogados, Lisboa, Ano 62, vol. III, dez. 2002, Disponível em < http://www.oa.pt/Conteudos/Artigos/detalhe_artigo.aspx?idc=1\&idsc=16886\&ida=16892>. Acesso em 05 mai. 2014; RODRIGUES, Walter dos Santos. A duração razoável do processo na emenda constitucional $\mathrm{n}^{\mathrm{o}}$ 45. Revista eletrônica de direito processual, Rio de Janeiro, ano 2, vol. II, jan.-dez. 2008, p. 320.

${ }^{231}$ BARBOSA MOREIRA, José Carlos. O problema da duração dos processos: premissas para uma discussão séria. Revista Magister de Direito Civil e Processual Civil. Porto Alegre: Magister, v. 2, n. 12, p. 27-36, maio/jun. 2006, p. 29.

${ }^{232}$ Cf. Resolução do Conselho Nacional de Justiça n ${ }^{\circ}$ 198, de $1^{\circ}$ de julho de 2014.

${ }^{233}$ SILVA, Paulo Eduardo Alves da. Gerenciamento de processos judiciais. São Paulo: Saraiva, 2010, p. 29.

${ }^{234}$ Cf. a classificação de Fernando da Fonseca Gajardoni, apresentada em maiores detalhes na introdução deste trabalho.
} 
No Brasil, as técnicas judiciais são, em geral, as mais difundidas, a citar, como exemplo, a adequação da técnica processual às peculiaridades do direito material tutelado ${ }^{235}$, e a intensificação da presença do juiz no controle do processo $^{236}$.

$\mathrm{Na}$ execução, especificamente, se observa esta situação. A maioria da doutrina aborda técnicas judiciais de aceleração do processo, notadamente a abreviação de procedimentos, com simplificação de formas e redução de atos ${ }^{237}$, tendência que se materializou recentemente com a introdução do processo sincrético por meio das Leis $n^{\circ}$ 11.232 de 22 de dezembro de 2005 e n 11.382 , de 06 de dezembro de 2006 e que passaram ao largo de esgotar as tantas propostas que avançam na mesma direção ${ }^{238}$.

Porém, como visto, as técnicas judiciais não são a única forma de buscar a razoável duração do processo. Todos os três tipos de técnicas de aceleração se estendem à execução e podem ser funcionais à solução dos problemas encontrados nesta seara.

Este trabalho tem por objeto analisar a pertinência da desjudicialização como técnica extrajudicial de aceleração do processo, razão pela qual descabem maiores aprofundamentos acerca das técnicas judiciais e extraprocessuais.

Para tanto, é necessário, antes, compreender qual a atual situação da execução no Poder Judiciário em termos de razoável duração do processo e se, de fato, ela demanda intervenção com vistas à celeridade. É o que será feito a seguir.

${ }^{235}$ MARINONI, Luiz Guilherme. O direito à efetividade da tutela jurisdicional na perspectiva da teoria dos direitos fundamentais. Revista de Direito Processual Civil. Curitiba: Gênesis, 2003, p. 306; BEDAQUE, José Roberto dos Santos. Efetividade do processo e técnica processual. 3 ed. São Paulo: Malheiros, 2010, p. 51.

${ }^{236}$ CRUZ E TUCCI, José Rogério. Garantias constitucionais da duração razoável e da economia processual no projeto do CPC. Revista Magister de Direito Civil e Processual Civil, Porto Alegre, ano VIII, no 43, jul.-ago. 2011, p. 32.

${ }^{237}$ GRECO, Leonardo. Novas perspectivas da efetividade e do garantismo processual. In: MITIDIERO, Daniel; AMARAL, Guilherme Rizzo (coord.). Processo Civil: estudos em homenagem ao Professor Doutor Carlos Alberto Alvaro de Oliveira. São Paulo: Editora Atlas, 2012, p. 278.

${ }^{238}$ Leonardo Greco menciona uma série de alterações que seguem o mesmo caminho, como, por exemplo, a criação de ritos executórios sumários ou sumaríssimos conforme o valor ou o tipo de obrigação (A execução e a efetividade do processo. Revista de processo, São Paulo, ano 24, vol. 94, abr-jun. 1999, p. 48). 


\subsection{A sobrecarga do Poder Judiciário e a contribuição dos processos executivos}

Aqui, serão pontuadas a atual situação do Poder Judiciário e do vigente modelo judicializado de execução.

Para tanto, o primeiro passo é analisar a principal fonte de dados estatísticos hoje disponível no país: os relatórios Justiça em Números, publicados anualmente pelo Conselho Nacional de Justiça, mais especificamente as duas versões mais atuais: os relatórios 2014 que analisa os dados do ano-base 2013 - e 2013 - que analisa os dados do ano-base 2012.

Estas pesquisas estatísticas seguem os mesmos delineamentos metodológicos desde 2009, quando foi publicada a Resolução n 76/2009 do próprio Conselho. Os dados são coletados pelos presidentes de cada Tribunal, podendo delega-los a magistrados ou servidores, e são remetidos anualmente ou semestralmente para o Conselho Nacional de Justiça, encarregado de congregar e sistematizar as informações e, finalmente, publicá-las num relatório único, o supracitado Justiça em Números.

Trata-se de uma iniciativa pioneira e recente no Brasil e, a bem da verdade, ainda embrionária. Isto porque não há um detalhamento dos problemas enfrentados ${ }^{239}$ - em que pesem as constantes evoluções, os dados coletados ainda têm escopo generalista - e, por conta disso, suas causas e variáveis raramente são identificadas ${ }^{240}$. Além disso, a própria confiabilidade dos dados é questionável: a contagem de processos, por exemplo, é feita em cada cartório e não há qualquer sistema revisional institucionalizado para se confrontar as informações.

\footnotetext{
${ }^{239}$ Heitor Vitor Mendonça Sica registra a raridade de estudos estatísticos críticos e a baixa frequência com que tais análises são requisitadas quando da elaboração de novas leis processuais, ignorando-se seus valores na gestão de recursos físico e humanos do Poder Judiciário (Perfis do contraditório e da ampla defesa na execução fiscal federal. Gestão e jurisdição: o caso da execução fiscal da União - Série "Diálogos para o desenvolvimento" v.9. CUNHA, Alexandre dos Santos; ALVES DA SILVA, Paulo Eduardo (coord.). Brasília: IPEA, 2013, p. 209).

${ }^{240}$ PARENTONI, Leonardo Netto. A Celeridade no Projeto do novo CPC. Revista da Faculdade de Direito da Universidade Federal de Minas Gerais, Belo Horizonte, v. 59, junho-dezembro 2011, p. 129.
} 
Diante disso, há de se reconhecer que, a partir dos dados hoje disponíveis, dificilmente se pode chegar a um diagnóstico cirúrgico que indique precisamente as providências necessárias para a melhoria do quadro ${ }^{241}$. Contudo, sua atual estrutura permite ao menos uma primeira visão científica da situação enfrentada pelo Poder Judiciário, fornecendo alguns elementos estatísticos para as análises e propositura de soluções possíveis para as dificuldades estruturais enfrentadas.

O estudo a seguir selecionou três grupos de dados que são relevantes para a proposta: a situação orçamentária, o fluxo de processos e as taxas de congestionamento. Em cada tópico, será seguida uma mesma metodologia, a seguir exposta.

Inicialmente, serão abordados os dados referentes ao Poder Judiciário como um todo, para que se tenha uma noção geral da situação enfrentada. A grande desvantagem desta análise é que abarca todos os tipos de processo, tanto de conhecimento quanto de execução, de todos os órgãos do Poder Judiciário, excluídos apenas o Supremo Tribunal Federal (STF) e os conselhos ${ }^{242}$, situação que contempla, portanto, elementos que não interessam ao objeto do trabalho.

É assim que, em um segundo momento, considerando que o trabalho trata de execução e que os procedimentos gerais de execução por quantia previstos do Código de Processo Civil foram adotados como premissas para a análise da desjudicialização, serão empregados dois critérios cumulativos, sempre no intento de analisar os dados que guardarem maior proximidade com os objetos de estudo.

\footnotetext{
${ }^{241}$ HASSON, Roland; BACK, Hermínio. Crise na prestação jurisdicional: uma solução radical. In: GUNTHER, Luiz Eduardo (coord.). Jurisdição: crise, efetividade e plenitude institucional. Curitiba: Juruá, 2009, p. 668. ${ }^{242}$ Nestes dados, o Conselho Nacional de Justiça congrega informações do Superior Tribunal de Justiça (STJ), Tribunal Superior do Trabalho (TST), Tribunal Superior Eleitoral (TSE), Superior Tribunal Militar (STM), Tribunais de Justiça Estaduais (TJs) e do Distrito Federal e Territórios (TJDFT), Tribunais Regionais Federais (TRFs), Tribunais Regionais do Trabalho (TRTs), Tribunais Militares Estaduais (TJMs), Tribunais Regionais Eleitorais (TREs) e Justiça Militar da União (JMU).
} 
A primeira medida será, sempre que possível, a busca por dados referentes aos tipos de processo correspondentes à execução por quantia do Código de Processo Civil ${ }^{243}$.

Neste particular, impende esclarecer que o Conselho Nacional de Justiça, em seus relatórios anuais, divide os processos de conhecimento entre criminais e não criminais e os processos executivos entre extrajudiciais - subdivididos entre execuções fiscais e execuções não fiscais - e judiciais - subdivididos em execuções criminais e não criminais. Logo, no que concerne à classificação empregada pelo Conselho, interessam, principalmente, os dados coletados para execuções extrajudiciais não fiscais - onde se incluem as execuções autônomas por quantia - e para execuções judiciais não criminais - onde se incluem os cumprimentos de sentença por quantia.

Contudo, vale destacar que, nestes grupos de processos executivos, o Conselho Nacional de Justiça inclui todos os tipos de prestação - pagar quantia, entregar, fazer e não fazer - decorrentes de relações civis, trabalhistas, eleitorais e militares, tanto em âmbito estadual quanto federal, em primeiro, segundo e terceiro graus, desde que não sejam fiscais ou criminais, de modo que nem sempre o procedimento executivo informado coincidirá com o adotado como premissa do trabalho.

É assim que se justifica a segunda medida, qual seja, um enfoque aos dados referentes à Justiça Estadual, já que, nesta seara do Judiciário, em regra, as execuções extrajudiciais não fiscais e as execuções judiciais não criminais seguem os ritos previstos no Código de Processo Civil e, na maioria das vezes, como procedimento principal.

Com isso, restará indistinto apenas o tipo de prestação executada, se por quantia, entrega de coisa, fazer ou não fazer. Esta discriminação, contudo, não ganha muito relevo para o fim pretendido neste momento, já que o intuito é apenas estampar a situação, em termos de quantidade e congestionamento de processos, da execução majoritariamente

\footnotetext{
${ }^{243} \mathrm{Na}$ frente que analisa a situação orçamentária, não há dados que individualizem as despesas e receitas conforme o tipo de processo. Diante disso e admitindo-se que o suprimento desta lacuna demandaria grande e dedicada pesquisa, nesta frente não haverá a aludida discriminação.
} 
praticada com fundamento no Código de Processo Civil, em seu atual modelo preponderantemente judicializado.

As especificidades da execução de pagar quantia em termos de duração do processo, serão levadas em conta no penúltimo tópico, quando será debruçado um enfoque empírico à tramitação da execução por quantia dentro de um cartório e vara judiciais, de modo a observar sua repercussão no dia a dia forense, notadamente o esforço que tais processos demandam da estrutura judiciária.

\subsubsection{Situação orçamentária}

Em termos orçamentários, ao longo do ano de 2012, o Poder Judiciário despendeu, ao todo, $\mathrm{R} \$ 57,2$ bilhões, valor 7,2\% maior que em 2011. Em 2013, este valor teve um aumento de $1,5 \%$, saltando para $\mathrm{R} \$ 61,6$ bilhões.

Comparadas com o total de despesas, em 2012, os gastos com recursos humanos correspondiam a $88,7 \%$ do total de gastos, cerca de $\mathrm{R} \$ 50,75$ bilhões. No ano seguinte houve um aumento quantitativo - R\$55,3 bilhões $^{244}$ - e proporcional - passou para $89,3 \%$ do total de despesas - de tais valores.

As despesas com informática, em 2012, contabilizavam cerca de 4,5\% do total - ou $\mathrm{R} \$ 2,6$ bilhões. No ano seguinte, 2013, estas despesas tiveram um ligeiro aumento em valores absolutos, passando a $\mathrm{R} \$ 2,7$ bilhões, porém um decréscimo proporcional, computando-se $4,3 \%$ do total.

Quanto à arrecadação, enquanto em 2012 foi de R $\$ 24,7$ bilhões, equivalente a apenas 46,3\% da despesa total, em 2013 teve expressivo aumento em relação ao ano anterior, porém, ainda assim, a arrecadação não ultrapassou os R $\$ 34$ bilhões, 59,4\% do total de despesas.

\footnotetext{
${ }^{244}$ Em 2012 contavam-se 16.138 magistrados e 396.933 funcionários, entre efetivos e auxiliares - nesta categoria computados terceirizados, estagiários, juízes leigos e conciliadores - sendo que $78 \%$ destes servidores atuavam diretamente na atividade fim, ou seja, na prestação jurisdicional. Em 2013 houve aumento geral no número de servidores: 16.429 magistrados e 412.336 servidores, sendo que o percentual de profissionais dedicados à atividade fim também teve ligeiro aumento, passando para 78,7\% .
} 
O Judiciário Estadual, em 2013, teve R \$ 34 bilhões de despesas ao todo, aumento de 2,3\% em relação ao ano anterior e responsável por 59,4\% do total de despesas do Poder Judiciário.

As despesas com recursos humanos, nesta esfera, equivaleram, em 2013, a $\mathrm{R} \$ 29,9$ bilhões, valor quantitativamente maior que em 2012 - quando foram computadas R $\$ 29,2$ bilhões -, porém proporcionalmente equivalente ao ano anterior, na faixa de $88 \%$ do total de despesas, muito similar ao quadro geral do Poder Judiciário.

Já as despesas com informática, em 2013, foram de R \$1,5 bilhão, valor 24,6\% maior que no ano anterior e correspondente a $4,4 \%$ do total de despesas, também havendo compatibilidade proporcional entre esta esfera e o quadro geral do Poder Judiciário.

A arrecadação total deste ramo, no ano de 2013, inclusas custas e emolumentos processuais, receitas de execução fiscal e impostos causa mortis, totalizaram, aproximadamente, $\mathrm{R} \$ 15,3$ bilhões, 33,54\% a mais do que no ano de 2012, mas, ainda assim, correspondente a apenas $45 \%$ do total de despesas, diferença de $14,4 \%$ do déficit suportado pelo Judiciário em geral.

\subsubsection{Fluxo de processos}

Quanto ao fluxo de processos, no ano de 2012, 92,2 milhões de processos tramitaram pelo Judiciário, sendo que 64,1 milhões já vinham do ano anterior - processos pendentes, portanto - e outros 27,9 milhões foram iniciados naquele ano. Ao seu término, 66,9 milhões de processos foram transportados para o ano de 2013.

Já em 2013, muito por conta do número maior de casos pendentes vindos de 2012, tramitaram 95,12 milhões de processos pelo Judiciário - 66,9 milhões de processos pendentes, mais 28,3 milhões de processos novos. Deste total, apenas 27,7 milhões de processos foram baixados, ou seja, para 2014, novamente, foi deixado um número de

processos pendentes maior do que no ano anterior. Este aumento, aliás, é contínuo e progressivo desde 2009, quando foi implantada a atual metodologia.

Já no âmbito do Judiciário estadual, em 2012 tramitaram 72 milhões de processos 52 milhões de processos pendentes de 2011, mais 20 milhões de novos processos equivalente a $78 \%$ do total de processos que tramitaram no Poder Judiciário. O quantitativo 
de 19,2 milhões de processos baixados, implicou no transporte, para 2013, de um saldo de 52,7 milhões de processos pendentes.

No ano seguinte, 2013, impulsionado pelo maior número de processos pendentes, o Judiciário estadual teve em trâmite um total de 74,2 milhões de processos, ainda equivalente aos mesmos $78 \%$ do total que tramitou naquele ano em todo o Poder Judiciário. Novamente, foram baixados menos processos do que o quantitativo de novas demandas - 18,9 milhões de processos -, remanescendo, para o ano de 2014, um saldo de 55,3 milhões, ainda maior que o proveniente dos anos anteriores.

Nesta seara, especificamente quanto às execuções extrajudiciais não fiscais e às execuções judiciais não criminais, estas modalidades contribuíram, em 2012, com um total de 5,97 milhões de processos, deixando uma pendência de 4,5 milhões de processos para o ano de 2013 - 2,1 milhões de execuções fundadas em títulos extrajudiciais não fiscais e 2,4 milhões de execuções fundadas em títulos judiciais não criminais - não muito superior ao acumulado de 2011, de 4,43 milhões de processos.

Porém, no ano seguinte, 2013, quando o total de processos desse tipo na Justiça Estadual foi de 7 milhões, o acúmulo sofreu aumento mais expressivo, tendo sido lançados, para o ano de 2014, 5,35 milhões de processos executivos das categorias sob exame - 2,23 milhões de execuções fundadas em títulos extrajudiciais não fiscais e 3,12 milhões de execuções fundadas em títulos judiciais não criminais.

\subsubsection{Taxas de congestionamento}

A taxa de congestionamento é um índice apurado pelo Conselho Nacional de Justiça que considera o total de casos novos, os casos baixados e o número de processos que remanesceram ao final do ano anterior. Chega-se à taxa dividindo-se o número de processos 
baixados pela soma dos processos novos e dos remanescentes do ano anterior. O resultado deve ser subtraído de $u^{245}$.

Todos os tipos de processos analisados pelo Conselho Nacional de Justiça têm taxas de congestionamento positivas, oscilando, em 2013, entre um máximo de $91 \%$, referente às execuções extrajudiciais fiscais, e um mínimo de 47\%, referente aos processos de conhecimento em segundo grau.

No ano de 2013, a taxa de congestionamento do Poder Judiciário como um todo era de 70,9\%, o que significa que, em média, de cada 100 processos que tramitaram no ano de 2013, aproximadamente 29 foram baixados no mesmo período. Este percentual geral é 0,9\% maior do que o registrado no ano de 2012. Aliás, de 2012 para 2013, nenhum tipo de processo teve redução nas taxas de congestionamento, mas sim aumento de, ao menos, um ponto percentual em seis das nove categorias analisadas - as demais permaneceram inalteradas.

Nesta seara, os processos executivos, em que pese não serem a maioria em quantidade absoluta - corresponderam, em 2013, a cerca de 45,3\% do total de processos que tramitaram naquele ano -, são os que apresentam maiores taxas de congestionamento.

Tanto em 2012 como em 2013, qualquer tipo de processo executivo acusava maior taxa de congestionamento do que qualquer tipo processo de conhecimento. A título de exemplo, em 2013, as execuções judiciais não criminais, mais fluidas dentre as execuções, contavam com $70 \%$ de taxa de congestionamento, enquanto os processos de conhecimento criminais em primeira instância, os mais congestionados dentre os processos de conhecimento, contavam com $68 \%$ de taxa de congestionamento.

Na Justiça Estadual a situação é mais grave. Também nesta seara todos os tipos de processo têm taxas positivas de congestionamento e qualquer tipo de processo executivo tem maior taxa de congestionamento que qualquer tipo de processo de conhecimento, com uma ligeira diferença nos percentuais: em 2013, 70\% para as execuções judiciais criminais de

245 (CONSELHO NACIONAL DE JUSTIÇA. Disponível em <http://www.cnj.jus.br/gestao-eplanejamento/gestao-e-planejamento-do-judiciario/indicadores/486-rodape/gestao-planejamento-epesquisa/indicadores/13659-03-taxa-de-congestionamento>. Acesso em 16 abr. 2015.). 
penas não privativas de liberdade, mais fluidas no gênero, e 69\% para os processos de conhecimento criminais de primeira instância, mais congestionados do gênero. Porém, em 2013, a taxa de congestionamento geral foi de $75 \%, 5$ pontos percentuais acima da taxa de congestionamento geral do Poder Judiciário e 1,7 pontos percentuais acima do índice registrado na própria Justiça Estadual no ano de 2012.

Dentre os tipos de processo relevantes para o trabalho, a Justiça Estadual, em 2013, registrou taxas de congestionamento de $79 \%$ para execuções extrajudiciais não fiscais $-1 \%$ acima da taxa registrada em 2012 - e $75 \%$ para execuções judiciais não criminais - 1\% abaixo do percentual registrado em 2012. Isto significa que, na Justiça Estadual, em 2013, a cada 100 execuções extrajudiciais não fiscais, apenas 21 eram baixadas no mesmo ano; enquanto que, dentre as execuções judiciais não criminais em trâmite, a cada 100, apenas 25 eram baixadas no mesmo ano.

\subsubsection{O impacto na vara e cartório judiciais}

Fixados os aspectos concernentes ao Poder Judiciário e das execuções extrajudiciais não fiscais e judiciais não criminais, cabe um enfoque sobre o trâmite da execução por quantia em um cartório e vara judiciais.

A abordagem ganha relevo principalmente porque, a despeito de ser muito significativa quando da análise de técnicas extrajudiciais de aceleração do processo - já que conhecer a situação interna do Poder Judiciário é fundamental para se concluir pela necessidade de exteriorização de seus atos -, não é usual no estudo do Processo Civil, uma vez que o enfoque, em geral, é voltado para o processo como um todo, enquanto meio de solução de uma controvérsia de direito material.

O conhecimento do dia a dia de um cartório e vara judiciais, porquanto raramente objeto de análise doutrinária, demandou pesquisa in loco. Como o inciso I do artigo 96 da Constituição Federal garante a cada Tribunal autonomia para organizar suas secretarias e seus serviços, a grande quantidade de variáveis daí decorrente impôs a necessidade de arbitramento de determinados critérios à pesquisa para que se chegasse a um resultado minimamente informativo. 
Assim, no primeiro corte metodológico foi escolhido, no âmbito da Justiça Estadual - pelas mesmas razões expostas no tópico anterior - uma comarca do interior, subordinada ao Tribunal de Justiça do estado de São Paulo.

O Tribunal de Justiça do estado de São Paulo tem taxa de congestionamento geral, apurada em 2013, de 82,4\%. Esta taxa é a média apurada entre o congestionamento de processos de conhecimento - 73.6\% - e os de execução, significativamente mais problemáticos - 91,2\%. Todos os números são significativamente superiores às médias da Justiça Estadual como um todo, já relatadas acima.

A comarca analisada, enquanto uma das maiores do Estado - possui, além de um foro regional, 10 varas cíveis, 6 varas criminais, 4 varas de família e sucessões, 2 varas da fazenda pública, 2 varas de juizado especial cível, 1 vara de execuções criminais e 1 vara de infância e juventude - traz contribuição significativa para este número.

Neste cenário, de modo a eliminar ao máximo variáveis como problemas de gestão, descumprimento de orientações dos Tribunais, limitações técnicas e de pessoal, permanentes ou transitórias, dentre outras intercorrências possíveis no dia a dia de uma vara e cartório judiciais, foi escolhida uma Vara Cível local, que divide com outras onze varas a carga de processos cíveis distribuídos e é notória por ser uma das mais estáveis e ágeis da Comarca, apresentando grande comprometimento com a gestão de processos, qualidade e eficiência da prestação jurisdicional.

Integrada ao processo eletrônico desde março de 2013, referida Vara, em abril de 2015, época da pesquisa, contava com um total de 7.449 processos, sendo 4.167 , ou 55,94\%, em fase de conhecimento e 3.282, ou 44,06\%, em fase executiva. Destes, 1.500 processos eram execuções fundadas em títulos extrajudiciais e 1.782 execuções fundadas em títulos judiciais.

Para arcar com o contingente, a vara judicial contava, no gabinete, com dois juízes um titular e um auxiliar -, cada qual assistido por dois servidores - assistente judiciário e escrevente - e dois estagiários de ensino superior. O respectivo cartório, por sua vez, possuía quinze servidores - entre escrivão, chefes de seção, escreventes e agentes administrativos - 
e três estagiários de ensino médio. Todos estes profissionais estavam em atividade e todos possuíam capacitação técnica para operação dos sistemas informáticos ${ }^{246}$.

Como a pesquisa tinha por objetivo averiguar a tramitação interna de um processo de execução por quantia no cartório e gabinete judiciais e os atos praticados em tais procedimentos também comportam grande quantidade de variáveis - tais como a quantidade de litigantes, tipo de bem penhorado, repetição de diligências e postura das partes, dentre outras - optou-se por estabelecer um procedimento hipotético como padrão de análise. Este procedimento, mínimo dentro de uma execução que necessite recorrer à substituição da vontade do devedor pelo Estado-juiz, adotou as seguintes premissas: um exequente, pessoa jurídica regularmente constituída e representada, contra um executado, pessoa jurídica regularmente constituída e representada; execução autônoma, fundada em título extrajudicial; inexistência de óbices quanto às condições da ação e pressupostos processuais; executado regularmente citado, deixa de pagar no prazo regulamentar; Oficial de Justiça retorna ao local de citação e não localiza bens penhoráveis; executado constitui advogado nos autos porém não se defende; exequente pede penhora on line de ativos financeiros, resultando em bloqueio e penhora do valor total do débito; exequente se manifesta pela satisfação do débito e pede o levantamento dos valores; extinção do processo pela satisfação da pretensão.

Na execução de título extrajudicial, ajuizada a inicial, o processo aguarda numa fila de trabalho denominada "conclusos - aguardando análise inicial", em que o cartório analisa os pleitos iniciais e, em se tratando de pleito simples, como no exemplo adotado, elabora minuta da decisão inicial de recebimento. É uma fila de trabalho de análise diária e que, na sede da pesquisa, em se tratando de decisão simples, não retém o processo por mais de 48 horas.

Conferida e assinada a decisão inicial pelo Juiz, o processo segue, concomitantemente, para duas novas filas de trabalho, controladas ao mesmo tempo pelo

\footnotetext{
${ }^{246}$ Este é um problema recorrente em cartórios judiciais. Nem todos os servidores conseguem se adaptar às mudanças, principalmente tecnológicas e de informatização que se intensificaram com a adoção do processo eletrônico. Estas dificuldades, quando associadas a outros problemas de gestão no cartório, tendem a trazer grandes prejuízos ao andamento processual.
} 
cartório, denominadas "encaminhar para a publicação" e "ag.análise". Na primeira, "encaminhar para publicação", fila comum a todo e qualquer ato decisório ou de cumprimento de diligência de interesse das partes, o cartório elabora o extrato da decisão proferida ou da diligência cumprida e a encaminha para disponibilização no Diário de Justiça via sistema eletrônico. Nesta fila de trabalho, sempre que há necessidade de publicação, o processo demora, em média, 7 dias até ser remetido à Imprensa Oficial.

Na segunda, "ag.análise", os respectivos mandados de citação e de penhora e avaliação são digitados, impressos e instruídos com a documentação competente. Nesta etapa, a expedição leva, em média, 20 dias.

Estes mandados, impressos, são deixados à disposição da Central de Mandados, que recolhe os documentos e distribui para o Oficial de Justiça competente. Durante o período em que se aguarda o cumprimento da diligência pelo Oficial de Justiça, o processo é alocado na fila "ag. prazo", onde permanece, em média, de 45 dias, aguardando a atuação daquele profissional.

Cumprida a diligência, o Oficial de Justiça certifica o cumprimento nos autos eletrônicos - onde, num primeiro momento, a certidão fica indisponível às partes - e devolve os mandados físicos à Central de Mandados. A Central, por sua vez, remete os mandados de volta ao Cartório, que digitaliza os documentos e os libera nos autos, juntamente com a certidão elaborada pelo Oficial de Justiça. Entre o recebimento da documentação pelo cartório e a liberação nos autos, decorrem, em média, 5 dias.

Os autos são, então, remetidos à fila de trabalho "ag.prazo", à espera de eventuais embargos do devedor. Decorrido em branco o prazo para embargos, o cartório certifica o fato e elabora ato ordinatório para que o exequente se manifeste em termos de prosseguimento do feito. Concluído o ato, o processo é, novamente, alocado na fila “encaminhar para publicação", aguardando remessa para a Imprensa Oficial. Entre o decurso do prazo concedido à parte e a expedição do ato ordinatório decorrem, em média, 10 dias. $\mathrm{O}$ encaminhamento do ato à Imprensa Oficial, como dito, leva cerca de 7 dias. Após, remetese novamente o processo para a fila "ag.prazo", à espera da parte.

Seguindo-se o procedimento hipotético, recebido o pedido de penhora on-line, já com as respectivas custas recolhidas, o processo é remetido para nova fila de "conclusão", onde o cartório elabora a minuta de decisão deferindo a pesquisa e penhora on-line e a submete 
para nova fila de trabalho, denominada "Bacenjud-cls.para decisão", onde o processo aguarda a assinatura do juiz. A elaboração da minuta leva, em média, 8 dias e a assinatura do juiz não excede 24 horas.

Subscrita pelo juiz e, portanto, deferida a penhora on-line, a decisão fica indisponível para as partes e, o próprio cartório, em cerca de 8 dias, elabora o requerimento de pesquisa junto ao sistema Bacenjud. O magistrado assina o requerimento e o processo é encaminhado para a fila de trabalho "ag.resposta", onde fica por 48 horas à espera da resposta do Banco Central.

Recebida a resposta, o cartório, em até 48 horas, transfere a quantia bloqueada para conta judicial e libera nos autos o resultado da pesquisa, a decisão que a deferiu e um ato ordinatório provocando eventual manifestação do executado. Assinado pelo juiz em até 24 horas, o processo é encaminhado para publicação - respeitada a regra geral de 7 dias para encaminhamento à Imprensa Oficial - e é alocado na fila de trabalho "ag.prazo", à espera da parte.

Após o decurso em branco do prazo concedido à parte, o cartório, em cerca de 10 dias, certifica o fato e elabora novo ato ordinatório para exequente se manifestar em prosseguimento. Novamente os autos são enviados para publicação - outros 7 dias até o encaminhamento - e alocados na fila “ag.prazo", agora à espera do exequente.

Conforme o procedimento padrão, recebido requerimento do credor dando por satisfeito o débito e pedindo levantamento do valor penhorado, os autos são novamente alocados em fila de "conclusão", na qual o cartório, em até 5 dias, elabora sentença deferindo expedição do mandado e extinguindo o feito. Assinado o ato pelo juiz, o processo, a exemplo do que ocorrera na decisão inicial, segue para duas filas concomitantes: "encaminhar para a publicação" - onde respeita e regra geral de 7 dias para encaminhamento à Imprensa Oficial - e "ag.análise". Nesta última, em até 7 dias, o cartório elabora mandado de levantamento e certidão atestando a expedição do mandado e a data a partir da qual o documento pode ser retirado pela parte. Também esta certidão é remetida para publicação em até 7 dias.

Finalmente, o processo é alocado na fila de trabalho "ag.prazo" à espera do decurso do prazo recursal e consequente trânsito em julgado. Ocorrendo o fato, em cerca de 10 dias o cartório certifica, comunica no sistema a extinção do feito e envia o processo para a fila de “processos arquivados”, quando, finalmente, é encerrado. 


\subsubsection{Conclusões parciais}

Do exposto, pode-se concluir que, no Brasil, o Poder Judiciário é deficitário, necessitando de aportes orçamentários das respectivas esferas federativas para seu sustento. Os tributos, multas e emolumentos cobrados dos litigantes são insuficientes para custear a estrutura necessária à prestação jurisdicional.

Além disso, o material humano é, com enorme diferença, o maior custo que recai sobre o Poder Judiciário, custo este que tem aumentado quantitativa e proporcionalmente em relação ao orçamento total. Em contrapartida, no mesmo período, a informatização, postura que pode reduzir tanto a dependência de recursos humanos quanto as variáveis em torno do tempo do processo, teve queda proporcional.

Nota-se, ainda, um crescimento geral no número de processos que anualmente tramita no Judiciário e nas taxas de congestionamento de quase todos os tipos de processo $^{247}$, o que demonstra um sistema com sérias dificuldades para prover uma tutela jurisdicional em tempo razoável.

Na Justiça Estadual, especificamente, as execuções fundadas em títulos executivos extrajudiciais não fiscais e em títulos judiciais não criminais, categorias relevantes para este trabalho, em que pese não serem, quantitativamente, maioria dentre o contingente em trâmite nesta seara do Judiciário - compuseram, em 2013, cerca de 10\% do total de processos que tramitaram - e nem possuírem a maior taxa de congestionamento apurada - o que compete às execuções extrajudiciais fiscais -, ainda assim se constituem como grupos com crescimento quantitativo progressivo e elevadas taxas de congestionamento, sempre acima da taxa geral de congestionamento do Poder Judiciário, de modo que podem ser encaradas como agentes protagonistas da sobrecarga geral sofrida pelo Poder Judiciário.

247 SICA, Heitor Vitor Mendonça. Congestionamento viário e congestionamento judiciário. Revista de Processo, São Paulo, ano 39, v. 236, out. 2014, p. 14. 
A análise de um procedimento hipotético de execução por quantia não só confirmou este cenário como demonstrou que, mesmo em uma das mais simples dentre as possíveis configurações do processo executivo, os cartórios judiciais suportam a maior parte da sobrecarga.

Entre o início e o final do procedimento analisado, ao cartório coube a prática de quase todos os atos - cerca de 23 , afora os deslocamentos entre filas de trabalho -, com raras e apenas incidentais análises dos autos pelos gabinetes judiciais.

Aliás, sobrelevou a constatação de que o cartório protagoniza os atos executivos atribuídos ao Juízo. Mesmo quando um ato de teor decisório é exigido - e, diga-se, estes atos, em geral, são de menor complexidade na execução quando comparados com os dos processos de conhecimento -, os cuidados de análise, valoração, deliberação e até mesmo minuta da decisão, ficam a cargo do cartório, acionando-se o gabinete judicial apenas em situações mais complexas, a julgo do próprio cartório, ou para conferência e assinatura de atos já previamente elaborados pelos cartórios.

Há, inclusive, consenso entre os membros e servidores do local pesquisado de que os processos executivos demandam muito mais tempo e esforços do cartório do que os processos de conhecimento, a despeito de a execução representar contingente processual cerca de $11 \%$ menor.

Quanto aos juízes e seus assessores diretos, notou-se que suas atuações são incidentais. Sem prejuízo de sua relevância - porquanto há questões complexas que demandam deliberações jurídicas mais avançadas e, por isso, necessariamente levadas ao juiz, além, evidentemente, de concentrarem o poder de assinatura e convalidação dos atos , fato é que, quantitativamente, são muito menos expressivas do que aquelas promovidas no próprio cartório.

Finalmente, em termos de tempo de processo, somente em filas de trabalho, ou seja, nas ditas "etapas mortas”, em que nada é feito com o processo, à espera da prática do ato subsequente, são cerca de 177 dias. Isso em um dos cartórios mais ágeis da comarca e com um procedimento hipotético que, na prática, raramente se opera de tal forma fluida e objetiva. Em outros cartórios da comarca, com maiores dificuldades de gestão, ausência ou incapacitação profissional de servidores, dentre outros problemas, uma única fila de trabalho, como a de conclusão, pode demorar até 180 dias. Do mesmo modo, em outros 
procedimentos, com mais réus, mais dificuldades para localizar o executado e seu patrimônio, com outros tipos de bens penhorados, incidentes de conhecimento, dentre outros desdobramentos, este tempo tende a se majorar ainda mais.

Estes dados vão ao encontro da doutrina ${ }^{248} \mathrm{e}$, principalmente, das constatações registradas no estudo "Análise da Gestão e Funcionamento dos Cartórios Judiciais", confeccionado em 2007, pelo Ministério da Justiça. Na ocasião, dentre outras informações, apurou-se que, descontados os períodos em que os autos são levados ao juiz para alguma decisão ou retirados em carga para vista e manifestação, eles ficam nos cartórios entre $80 \%$ e $95 \%$ do tempo total de processamento ${ }^{249}$. Também consentâneos com a pesquisa a constatação da ampla utilização da "preparação de decisões" ou "despacho em preto"250, essenciais na organização da equipe coordenada e controlada pelo juiz ${ }^{251}$ com vistas ao funcionamento do cartório e vara judiciais como um todo.

Estes aspectos conjugados confluem para a constatação de que há, de fato, uma crise no Poder Judiciário e que a execução por quantia é um de seus elementos essenciais, principalmente em termos de consumo da estrutura disponível - com especial destaque à intensa utilização do tempo e recursos dos cartórios judiciais - e congestionamento de processos. Nestes termos, uma mudança de modelo processual, de modo a deslocar a

\footnotetext{
${ }^{248}$ STRAPAZZON, Carlos Luiz. Ius imperi e iuris dictio: a natureza política da tutela jurisdicional. In: GUNTHER, Luiz Eduardo (coord.). Jurisdição: crise, efetividade e plenitude institucional. Curitiba: Juruá, 2009 , p. 72

${ }^{249}$ MINISTÉRIO DA JUSTIÇA. Análise da Gestão e Funcionamento dos Cartórios Judiciais. Brasília: Ideal, 2007. Disponível em <http://www.migalhas.com.br/arquivo_artigo/art20071227.pdf〉. Acesso em 07 set. 2015, p. 23.

${ }^{250}$ Derivação da permissão insculpida no artigo $162, \S^{\circ}{ }^{\circ}$ da Constituição Federal, consiste na apreciação, geralmente pelo diretor, escrevente-chefe ou escrevente, dos requerimentos mais simples formulados pelas partes e na elaboração de uma minuta de decisão, que é submetida ao juiz e, se aprovada, por ele assinada (MINISTÉRIO DA JUSTIÇA. Análise da Gestão e Funcionamento dos Cartórios Judiciais. Brasília: Ideal, 2007. Disponível em 〈http://www.migalhas.com.br/arquivo_artigo/art20071227.pdf〉. Acesso em 07 set. 2015, p. 29).

${ }^{251}$ SILVA, Paulo Eduardo Alves da. Gerenciamento de processos judiciais. São Paulo: Saraiva, 2010, p. 73.
} 
execução para fora desta estrutura abarbada, ganha força como uma dentre as soluções possíveis $^{252}$.

Cabe, portanto, uma ampliação no estudo do instituto, analisando-se casos relevantes de desjudicialização da execução por quantia dentro de nosso ordenamento, para além do procedimento do Código de Processo Civil, e também em ordenamentos estrangeiros. De posse de tais informações será possível, finalmente, de modo comparativo, avaliar se esta técnica extrajudicial é juridicamente possível no Brasil, qual o preço a se pagar em termos de segurança jurídica e se é, realmente, funcional para a melhoria do quadro.

${ }^{252}$ Dentre as diversas propostas de soluções para a execução, cite-se o sintético, porém abrangente trabalho de Leonardo Greco, Novas perspectivas da efetividade e do garantismo processual. In: MITIDIERO, Daniel; AMARAL, Guilherme Rizzo (coord.). Processo Civil: estudos em homenagem ao Professor Doutor Carlos Alberto Alvaro de Oliveira. São Paulo: Editora Atlas, 2012. Na mesma esteira, ABELHA RODRIGUES, Marcelo; JORGE, Flávio Cheim. Ideias e propostas de agilização da marcha processual. In: CARNEIRO, Athos Gusmão; CALMON, Petrônio (org.). Bases científicas para um renovado direito processual. 2 ed. Salvador: Juspodivm, 2009, p. 771. 


\section{CAPÍTULO 02}

\section{A DESJUDICIALIZAÇÃO DA EXECUÇÃO POR QUANTIA NO QUADRO NORMATIVO CONTEMPORÂNEO}

\subsection{Procedimentos esparsos do ordenamento nacional}

Como se viu no capítulo anterior, a desjudicialização é fenômeno já presente no regramento nacional geral dado à execução por quantia certa. Entretanto, sua utilização é apenas incidental, de modo que prepondera o modelo executivo judicializado.

Todavia, há procedimentos previstos em legislação especial que avançam no processo de desjudicialização, prevendo uma maioria ou até mesmo totalidade de atos intermediados por terceiros e praticados fora do Poder Judiciário.

É assim que, aqui, a análise recairá sobre os três principais procedimentos de execução preponderantemente desjudicializada no Brasil: o decreto-lei $n^{\circ} 70 / 66$, que trata da execução extrajudicial movida pelo credor hipotecário vinculado ao sistema financeiro da habitação, a Lei n ${ }^{\circ}$ 9514/97, que prevê a possibilidade de o credor fiduciário alienar o bem imóvel em caso de inadimplemento, e os ensaios de desjudicialização da execução físcal, cujo debate tem se intensificado recentemente.

Não se ignora a existência de outros procedimentos de solução forçada que se passam fora do judiciário. Alguns não se valem de terceiro intermediário, de modo que fogem ao objeto de estudo, casos da venda do bem empenhado pelo credor pignoratício quando autorizado contratualmente a tanto - artigo 1.433 do Código Civil - ou da alienação promovida pelo proprietário fiduciário de bem móvel ante o inadimplemento do devedor artigo $2^{\circ}$ do Decreto-Lei n ${ }^{\circ}$ 911/1969.

Outros, casos dos leilões extrajudiciais de mercadorias depositadas em armazéns gerais e dos bens oferecidos em warrant - previstos no Decreto $\mathrm{n}^{\mathrm{o}} 1.102$, de novembro de 1903 -, da alienação da quota do condômino inadimplente em contratos de incorporação imobiliária - previsto na Lei $\mathrm{n}^{\circ} 4.591$, dezembro de 1964 - adotam este terceiro 
intermediário, aproximando-se da ideia de desjudicialização delimitada neste trabalho ${ }^{253}$. A despeito disso, optou-se pelo não aprofundamento em seus estudos, haja vista os fatos de serem verificados com menor frequência tanto no cotidiano quanto na doutrina e de não trazerem nenhuma característica de desjudicialização que não esteja presente nas três hipóteses a seguir delimitadas.

\subsubsection{O Decreto-Lei $n^{0} 70 / 66$}

Durante a década de 1960, o governo brasileiro pôs em prática um plano de desenvolvimento nacional que contemplava, entre outras coisas, a facilitação de crédito para construção de moradias por meio de um Sistema Financeiro da Habitação. Como contrapartida aos bancos provedores deste crédito, foi editado o Decreto-Lei $\mathrm{n}^{\circ} 70$, de 21 de novembro de 1966, que permitia aos credores de valores decorrentes de contratos atrelados ao Sistema Financeiro da Habitação executarem suas garantias hipotecárias por meio de um agente fiduciário externo ao Poder Judiciário ${ }^{254}$, escapando, assim, ao procedimento executivo previsto no Código de Processo Civil de 1939, então vigente ${ }^{255}$. Pelo mesmo motivo, posteriormente, a Lei $\mathrm{n}^{\circ} 9.514$ de 20 de novembro de 1997 facultou a via também às operações de financiamento imobiliário atreladas ao Sistema Financeiro Imobiliário, sempre que, em lugar de alienação fiduciária, se praticar a garantia hipotecária ${ }^{256}$.

Pelo procedimento, nos termos do artigo 31, a instituição credora, diante do inadimplemento de três ou mais prestações do devedor, formula pedido de execução ao agente fiduciário, juntando o título da dívida já registrado em Cartório de Imóveis, memória de cálculo detalhada do saldo devedor e cópias de avisos de cobrança da dívida.

\footnotetext{
253 BECKER, L.A. Contratos bancários: execuções especiais. São Paulo: Malheiros, 2002, p. 313.

${ }^{254}$ RIBEIRO, Flávia Pereira. A desjudicialização da execução civil. São Paulo: Saraiva, 2013, p. 45.

${ }^{255}$ DENARDI, Volnei Luiz. Execuções judicial e extrajudicial no sistema financeiro da habitação. São Paulo: Editora Revista dos Tribunais. 2009, p. 83.

${ }^{256}$ Ibidem, p. 85.
} 
O agente fiduciário é terceiro escolhido em comum acordo pelo credor e devedor, apontado já no contrato de hipoteca, sendo a ele vedada a manutenção de vínculos societários com as partes ${ }^{257}$. Deve, portanto, atuar com imparcialidade, sendo facultadas às partes requererem em juízo a destituição do agente sob o qual recaírem suspeitas de parcialidade ou inidoneidade ${ }^{258}$, podendo, ainda, ser responsabilizado por eventuais danos causados no exercício de suas atividades ${ }^{259}$.

O exercício da função é regulamentado pelo Banco Central do Brasil, especificamente na Resolução $\mathrm{n}^{\circ} 1.764$ de 31 de outubro de 1990, a qual estipula, em seu artigo $2^{\circ}$, como possíveis agentes fiduciários, os bancos múltiplos, bancos comerciais, bancos de investimento, bancos de desenvolvimento, Caixa Econômica Federal ${ }^{260}$, sociedades de crédito, financiamento e investimento, sociedades de crédito imobiliário, associações de poupança e empréstimo, companhias hipotecárias, sociedades corretoras de títulos e valores mobiliários e sociedades distribuidoras de títulos e valores mobiliários.

\footnotetext{
${ }^{257}$ Conforme literalidade do artigo $30, \S 3^{\circ}$ do Decreto-Lei $n^{\circ} 70 / 66$, “os agentes fiduciários não poderão ter ou manter vínculos societários com os credores ou devedores das hipotecas em que sejam envolvidos. ".

${ }^{258} \mathrm{O}$ artigo $41, \S 1^{\circ}$ do Decreto-Lei $\mathrm{n}^{\circ} 70 / 66$ é expresso ao prever que "se o credor ou o devedor, a qualquer tempo antes do início da execução conforme o artigo 31, tiverem fundadas razões para pôr em dúvida a imparcialidade ou idoneidade do agente fiduciário eleito no contrato hipotecário, e se não houver acôrdo entre êles para substituí-lo, qualquer dos dois poderá pedir ao Juízo competente sua destituição. ”.

${ }^{259}$ Conforme se depreende do artigo 40 do Decreto-Lei n ${ }^{\circ} 70 / 66$, "o agente fiduciário que, mediante ato ilícito, fraude, simulação ou comprovada má-fé, alienar imóvel hipotecado em prejuízo do credor ou devedor envolvido, responderá por seus atos, perante as autoridades competentes, na forma do Capítulo V da Lei número 4.595, de 31 de dezembro de 1964, e, perante a parte lesada, por perdas e danos, que levarão em conta os critérios de correção monetária adotados neste decreto-lei ou no contrato hipotecário.”.

${ }^{260}$ Desde o advento do Decreto-lei ${ }^{\circ}$ 2.291, de 21 de novembro de 1986, a Caixa Econômica Federal incorporou o Banco Nacional da Habitação, protagonista originário do Sistema Financeiro da Habitação, extinto nos dias de hoje.
} 
Em que pese o Decreto-Lei $n^{\circ} 70 / 66$ exigir que estes agentes fiduciários sejam credenciados junto ao Banco Central do Brasil ${ }^{261}$, essa exigência foi dispensada pela mencionada Resolução n ${ }^{\circ} 1.764$ de 31 de outubro de $1990^{262}$.

Este agente para quem o credor formula o requerimento analisa o título da dívida e exerce controle formal, confirmando a legitimidade de parte do executado, pertinência do imóvel dado em garantia e compatibilidade entre os documentos apresentados e o requerimento formulado ${ }^{263}$.

Identificando qualquer irregularidade, deve recusar o processamento do feito ${ }^{264}$; caso contrário, confirmados os requisitos, o agente notifica o devedor por meio do Cartório de Títulos e Documentos, instruindo a comunicação com demonstrativo discriminado do débito $^{265}$ e concedendo-lhe prazo de 20 dias, durante os quais a única alternativa ao devedor é a purgação da mora com o pagamento das prestações em atraso de seu contrato de financiamento.

Não sendo purgada a mora no prazo, fica autorizado o leilão do imóvel hipotecado, sem realização de penhora ${ }^{266}$ - exceção, portanto, à previsão do $\$ 1^{\circ}$ do artigo 655 do Código de Processo Civil. Para tanto, o agente fiduciário publica os editais e designa o leilão, primeiramente buscando atingir ao menos o valor da dívida e, caso negativo, numa segunda

\footnotetext{
${ }^{261}$ Conforme o artigo 30 do Decreto-Lei, "para os efeitos de exercício da opção do artigo 29, será agente fiduciário, com as funções determinadas nos artigos 31 a 38: [...] II - nas demais, as instituições financeiras inclusive sociedades de crédito imobiliário, credenciadas a tanto pelo Banco Central da República do Brasil, nas condições que o Conselho Monetário Nacional, venha a autorizar".

${ }^{262}$ Observa-se na literalidade da Resolução ${ }^{\circ} 1.764$ de 31 de outubro de 1990: "art. $2^{\circ}$ [...] As instituições referidas no caput deste artigo podem exercer as atividades ali previstas independentemente de credenciamento prévio pelo Banco Central do Brasil. (Incluído pela Resolução n ${ }^{\circ} 2.830$, de 25/4/2001.)". A doutrina critica esta Resolução, uma vez que, tratando-se de ato infralegal, não poderia ter disposto de forma contrária ao Decreto-Lei, de caráter legal (DENARDI, Volnei Luiz. Execuções judicial e extrajudicial no sistema financeiro da habitação. São Paulo: Editora Revista dos Tribunais. 2009, p. 110).

${ }^{263}$ DENARDI, Volnei Luiz. Execuções judicial e extrajudicial no sistema financeiro da habitação. São Paulo: Editora Revista dos Tribunais. 2009, p.87.

${ }^{264}$ Ibidem, p. 88 .

${ }^{265}$ BRESOLIN, Humberto Bara. Execução extrajudicial imobiliária: aspectos práticos. São Paulo: Atlas, 2013, p.93.

${ }^{266}$ DENARDI, Volnei Luiz. Execuções judicial e extrajudicial no sistema financeiro da habitação. São Paulo: Editora Revista dos Tribunais, 2009, p. 89.
} 
oportunidade, arrecadando o quanto possível e priorizando o pagamento das despesas com o procedimento e os honorários do agente fiduciário, ficando facultado ao exequente continuar perseguindo o débito remanescente contra executado ${ }^{267}$.

Mesmo após os 20 dias, o devedor tem até a assinatura do auto de arrematação para saldar o débito e recuperar o bem. Contudo, neste segundo momento, o débito será acrescido dos juros e correção monetária, além de penalidades previstas no contrato de hipoteca e remuneração do agente fiduciário, que já seriam devidas no prazo regulamentar ${ }^{268}$.

Ultimada a alienação, a carta de arrematação é assinada pelo leiloeiro, credor, agente fiduciário e 5 testemunhas, momento a partir do qual já pode ser levada para transcrição no Registro de Imóveis. Devidamente inscrita a carta, fica facultado ao arrematante, judicialmente, em ação autônoma, requerer sua imissão na posse ${ }^{269}$.

${ }^{267}$ DENARDI, Volnei Luiz. Execuções judicial e extrajudicial no sistema financeiro da habitação. São Paulo: Editora Revista dos Tribunais, 2009, p. 92. O critério fixado com base no valor do débito em vez do valor do imóvel e a possibilidade de o credor ainda cobrar judicialmente saldo remanescente é alvo de críticas por parte da doutrina e da jurisprudência. Este segmento entende que o critério fixado no valor do débito implica na inexistência de avaliação do imóvel, colocando em risco os envolvidos no negócio e terceiros eventualmente interessados na aquisição do bem, além de atentar contra a isonomia, na medida em que a execução hipotecária judicial - Lei no 5741/71 -prevê a exoneração do executado até mesmo se não houver licitantes na praça pública (BRESOLIN, Humberto Bara. Execução extrajudicial imobiliária: aspectos práticos. São Paulo: Atlas, 2013, p. 97 a 99).

${ }^{268} \mathrm{Na}$ literalidade do artigo 34 do Decreto-Lei, “é lícito ao devedor, a qualquer momento, até a assinatura do auto de arrematação, purgar o débito, totalizado de acôrdo com o artigo 33, e acrescido ainda dos seguintes encargos: I - se a purgação se efetuar conforme o parágrafo primeiro do artigo 31, o débito será acrescido das penalidades previstas no contrato de hipoteca, até $10 \%$ (dez por cento) do valor do mesmo débito, e da remuneração do agente fiduciário; II - daí em diante, o débito, para os efeitos de purgação, abrangerá ainda os juros de mora e a correção monetária incidente até o momento da purgação.”.

${ }^{269}$ Conforme Decreto-Lei, §2 , artigo 37, “[...]uma vez transcrita no Registro Geral de Imóveis a carta de arrematação, poderá o adquirente requerer ao Juízo competente imissão de posse no imóvel, que lhe será concedida liminarmente, após decorridas as 48 horas mencionadas no parágrafo terceiro dêste artigo, sem prejuízo de se prosseguir no feito, em rito ordinário, para o debate das alegações que o devedor porventura aduzir em contestação. ". 
O dinheiro da arrematação ou da purgação da mora é recebido pelo agente fiduciário, que desconta seus honorários, entrega o saldo ao credor - até o limite de seu crédito -, e eventual excedente ao devedor ${ }^{270}$.

Estes atos são todos praticados por agentes privados, quer seja o agente fiduciário, o leiloeiro ou o próprio tabelião de Títulos e Documentos, de modo que o procedimento é tratado por parte da doutrina como o principal exemplo nacional de um procedimento executivo desjudicializado ${ }^{271}$.

O assunto, porém, está longe de ser tratado de forma uníssona e há significativa oposição à adequação do procedimento ao devido processo legal constitucional. As críticas se enveredam principalmente pelas três frentes já destacadas neste trabalho: monopólio e inafastabilidade de jurisdição; imparcialidade e naturalidade do agente fiduciário e contraditório e ampla defesa.

Na primeira das frentes, monopólio e inafastabilidade de jurisdição, a crítica é formulada no sentido de que o procedimento do Decreto-Lei $n^{\circ}$ 70/66 viola estes preceitos quando delega poder jurisdicional a agentes externos ao judiciário, o que só se admite nas exceções expressamente previstas na Constituição Federal, dentre as quais não está prevista a execução ${ }^{272}$. Sequer a arbitragem poderia ser utilizada como argumento a endossar o procedimento sob exame, haja vista que nem mesmo ao árbitro, terceiro imparcial, foi delegado o poder de império necessário à satisfação das decisões ${ }^{273}$. No caso do DecretoLei, há quem entenda até mesmo que a ausência de parâmetros de imparcialidade do agente

\footnotetext{
270 Da literalidade do artigo 35 do Decreto-Lei: “o agente fiduciário é autorizado, independentemente de mandato do credor ou do devedor, a receber as quantias que resultarem da purgação do débito ou do primeiro ou segundo públicos leilões, que deverá entregar ao credor ou ao devedor, conforme o caso, deduzidas de sua própria remuneração. ".

${ }^{271}$ RIBEIRO, Flávia Pereira. A desjudicialização da execução civil. São Paulo: Saraiva, 2013, p. 47.

272 YOSHIKAWA, Eduardo Henrique de Oliveira. Execução extrajudicial e devido processo legal. São Paulo: Atlas, 2010, p. 114.

273 Ibidem, p. 117; DENARDI, Volnei Luiz. Execuções judicial e extrajudicial no sistema financeiro da habitação. São Paulo: Editora Revista dos Tribunais, 2009, p. 127 e 128.
} 
fiduciário configure o procedimento do Decreto-Lei em modalidade de autotutela ${ }^{274}$, a afastar a própria modalidade jurisdicional do procedimento.

Na segunda das frentes, imparcialidade e naturalidade do agente fiduciário, na esteira do entendimento supra, a crítica é no sentido de que o agente fiduciário atua como terceiro parcial, na medida em que não há critérios suficientes para abalizar sua nomeação ${ }^{275}$. Situações como a possibilidade de o agente fiduciário, ao mesmo tempo em que exerce esta função, atuar como exequente em processos semelhantes veiculados perante outros agentes fiduciários, contribuem para a ideia de que a imparcialidade é comprometida no sistema implementado pelo Decreto-Lei.

Além disso, a doutrina questiona se a previsão legal de as partes nomearem o agente fiduciário em comum acordo no contrato de fato provê garantia de naturalidade, haja vista as peculiaridades decorrentes do próprio negócio, que indicam que o mutuário não tem disponibilidade sobre o contrato, tais como a recorrente utilização de contratos de adesão, o conhecimento prévio que a instituição já tem do mercado de agentes fiduciários e o fato de tais profissionais pertencerem todos ao mesmo ramo de negócios do credor $^{276}$.

Finalmente, na terceira das frentes, contraditório e ampla defesa, os opositores ao procedimento entendem que o princípio não é aplicado neste rito, motivo pelo qual não possuiria legitimidade nos valores constitucionais ${ }^{277}$. Isto porque não é oportunizada defesa ao devedor antes da alienação de seu imóvel, cabendo-lhe a única alternativa de pagar o débito atrasado, relegando-se como única via de contraditório, em todo o ciclo

\footnotetext{
${ }^{274}$ GRINOVER, Ada Pellegrini. Novas tendências do direito processual de acordo com a Constituição de 1988. Rio de Janeiro: Forense Universitária, 1990, p. 200; YOSHIKAWA, Eduardo Henrique de Oliveira. Execução extrajudicial e devido processo legal. São Paulo: Atlas, 2010, p. 129; BECKER, L.A. Contratos bancários: execuções especiais. São Paulo: Malheiros, 2002, p. 319.

${ }^{275}$ DENARDI, Volnei Luiz. Execuções judicial e extrajudicial no sistema financeiro da habitação. São Paulo: Editora Revista dos Tribunais, 2009, p. 115.

${ }^{276}$ Ibidem, p. 116.

${ }^{277}$ MARINONI, Luiz Guilherme. O direito à efetividade da tutela jurisdicional na perspectiva da teoria dos direitos fundamentais. Revista de Direito Processual Civil. Curitiba: Gênesis, abr.-jun., 2003, p. 318; BECKER, L.A. Contratos bancários: execuções especiais. São Paulo: Malheiros, 2002, p. 315.
} 
expropriatório, apenas o potencial acesso ao Poder Judiciário mediante ação autônoma, sem qualquer meio específico para tanto ${ }^{278}$. Trata-se, pois, de autêntico procedimento unilateral, ante a inidoneidade dos meios de defesa para exercício do contraditório ${ }^{279}$.

$\mathrm{Na}$ jurisprudência, a discussão não foi menos intensa, culminando com o posicionamento do Supremo Tribunal Federal sobre o tema, oportunidade em que assentou a constitucionalidade do procedimento ${ }^{280}$. No estado de São Paulo, o Tribunal de Justiça assentou o mesmo entendimento por meio da súmula $n^{\circ} 20^{281}$, posição que vai de encontro ao entendimento anterior da mesma corte, então intitulada Tribunal de Alçada Civil de São Paulo, que, no enunciado de súmula $n^{\circ} 39$, registrou a inconstitucionalidade da execução prevista no Decreto-Lei $n^{\circ} 70 / 66$.

Esta divergência no Tribunal de Justiça do Estado de São Paulo passou a provocar novas suscitações do tema perante as Cortes Superiores, culminando com os Recursos Extraordinários $n^{\circ} 556.520$ e 627.106, atualmente em tramitação conjunta e com repercussão geral, que novamente analisam a constitucionalidade do dispositivo legal. O julgamento de tais processos está suspenso desde 18 de agosto de 2011, por conta de pedido de vista do Ministro Gilmar Mendes. Até então, dos seis votos proferidos, quatro defenderam a

\footnotetext{
${ }^{278}$ YOSHIKAWA, Eduardo Henrique de Oliveira. Execução extrajudicial e devido processo legal. São Paulo: Atlas, 2010, p. 104; RIBEIRO, Flávia Pereira. A desjudicialização da execução civil. São Paulo: Saraiva, 2013, p. 51; DENARDI, Volnei Luiz. Execuções judicial e extrajudicial no sistema financeiro da habitação. São Paulo: Editora Revista dos Tribunais, 2009, p. 124.

${ }^{279}$ BECKER, L.A. Contratos bancários: execuções especiais. São Paulo: Malheiros, 2002, p. 320.

${ }^{280}$ No julgamento do RE n ${ }^{\circ}$ 223075/DF de 23 de junho de 1998, relatoria do Ministro Ilmar Galvão, em que o recorrente alegava a inconstitucionalidade do procedimento por inexistir oportunidade para alegar a inobservância do princípio da equiparação salarial no reajustamento das prestações de seu contrato, a Corte consignou o entendimento de que o procedimento do Decreto-Lei ${ }^{\circ}$ 70/66 não impede que eventuais ilegalidades sejam reprimidas por procedimentos judicias, sendo lícito a qualquer juiz, por meio do agente fiduciário, sustar a venda do imóvel. Desde então, o entendimento vem sendo sistematicamente repetido naquele Tribunal.

281 “A execução extrajudicial, fundada no Decreto-Lei no 70, de 21.11.1966, é constitucional. ”.
} 
inconstitucionalidade do procedimento $^{282}$, a evidenciar tendência de reversão do entendimento inicial.

\subsubsection{A Lei $n^{0} 9.514 / 97$}

Em 1997, o governo brasileiro, diante do declínio do Sistema Financeiro da Habitação então vigente ${ }^{283}$, a fim de complementar a estrutura vigente ${ }^{284}$ e promover novo incentivo aos sistemas de financiamento imobiliário ${ }^{285}$, editou a Lei $\mathrm{n}^{\text {o }} 9514$, de 20 de novembro de 1997. Por meio dela, criou o Sistema de Financiamento Imobiliário, que passou a estimular as instituições financeiras ${ }^{286}$ a proverem créditos imobiliários garantidos pela alienação fiduciária do bem ${ }^{287}$.

A garantia fiduciária se consubstancia mediante registro, em Cartório de Registro de Imóveis, do contrato celebrado entre o credor fiduciário e o devedor fiduciante. Com isso, a propriedade e posse indireta do imóvel são transferidas ao credor. Ao devedor resta, tãosomente, a posse direta e o direito de aquisição do bem, obstado por condição suspensiva até

282 SUPREMO TRIBUNAL FEDERAL. Plenário analisa constitucionalidade de execução extrajudicial de dívida hipotecária. $\quad$ Disponível em <http://www.stf.jus.br/portal/cms/verNoticiaDetalhe.asp?idConteudo=186899>. Acesso em 09 jul. 2015.

${ }^{283}$ Humberto Bara Bresolin cita uma série de causas para a aludida crise, destacando a instabilidade econômica dos anos 80 como a principal delas (Execução extrajudicial imobiliária: aspectos práticos. São Paulo: Atlas, 2013, p. 87 e 88 ).

${ }^{284}$ TERRA, Marcelo. Alienação fiduciária de imóvel em garantia (lei $n^{\circ}$ 9.514/97, primeiras linhas). Porto Alegre: Sergio Antonio Fabris Editor, 1998, p. 17.

285 MARTINS, Samir José Caetano. A execução extrajudicial de créditos do sistema de financiamento imobiliário. Revista eletrônica de direito processual, Rio de Janeiro, ano 2, vol. II, jan.-dez. 2008, p. 292.

${ }^{286}$ Referida Lei, em seu artigo $2^{\circ}$, prevê como agentes operadores do Sistema, "as caixas econômicas, os bancos comerciais, os bancos de investimento, os bancos com carteira de crédito imobiliário, as sociedades de crédito imobiliário, as associações de poupança e empréstimo, as companhias hipotecárias e, a critério do Conselho Monetário Nacional - CMN, outras entidades". A despeito disso, o $\S 1^{\circ}$ do artigo 22 da própria Lei em referência, garante que não apenas os agentes integrantes do Sistema Financeiro Imobiliário, mas sim qualquer pessoa, física ou jurídica, pode contratar alienação fiduciária.

${ }^{287}$ BRESOLIN, Humberto Bara. Execução extrajudicial imobiliária: aspectos práticos. São Paulo: Atlas, 2013, p. 87. Até o advento desta Lei, a alienação fiduciária aplicava-se apenas à aquisição de bens móveis, nos termos da Lei $n^{\circ}$ 4728/65 e Decreto-Lei n ${ }^{\circ}$ 911/69. 
que o contrato de alienação seja quitado ${ }^{288}$, diferentemente do que ocorre na hipoteca, quando, além de possuidor, ele permanece proprietário do bem ${ }^{289}$.

Caso o devedor deixe de pagar a dívida decorrente do contrato, a Lei n ${ }^{\circ}$ 9514/97, a partir de seu artigo 26, prevê um procedimento para consolidação da propriedade ao credor, de modo que ele passe a ser proprietário pleno do bem ${ }^{290}$ sem que seja necessário acionar as vias executivas ordinárias.

Pelo procedimento, quando o devedor deixa de pagar a dívida, o fiduciário formula requerimento perante o Cartório de Registro de Imóveis, postulando pela intimação pessoal do fiduciante para que, no prazo de quinze dias, quite suas obrigações, incluídos os juros convencionais, as penalidades e os demais encargos.

Os serviços notariais e de registro têm previsão no artigo 236 da Constituição Federal e são regidos pelos ditames da Lei no 8.935/94. Tratam-se de segmentos atrelados ao Poder Judiciário, por ele fiscalizado, inclusive, encarregados de exercerem função pública em caráter privado.

Em que pese não lhe caber adentrar o mérito das parcelas e do cálculo da dívida ${ }^{291}$, o Oficial do Cartório exerce controle de legalidade do requerimento, analisando seus requisitos e aspectos formais, podendo recusar seu processamento, se for o caso $^{292}$. Se

\footnotetext{
${ }^{288}$ Em que pese a discussão ser mais relevante ao direito material que ao direito processual, cabe reverberar o registro de Marcelo Terra quanto aos três posicionamentos doutrinários acerca da posição jurídica do fiduciante: proprietário sob condição suspensiva, titular de expectativa de direito e titular de direito eventual ou expectativo, optando, em seu trabalho, por esta última (Alienação fiduciária de imóvel em garantia (lei $n^{\circ}$ 9.514/97, primeiras linhas). Porto Alegre: Sergio Antonio Fabris Editor, 1998, p. 39).

289 BRESOLIN, Humberto Bara. Execução extrajudicial imobiliária: aspectos práticos. São Paulo: Atlas, 2013, p. 108.

${ }^{290}$ MARTINS, Samir José Caetano. A execução extrajudicial de créditos do sistema de financiamento imobiliário. Revista eletrônica de direito processual, Rio de Janeiro, ano 2, vol. II, jan.-dez. 2008, p. 293.

${ }^{291}$ TERRA, Marcelo. Alienação fiduciária de imóvel em garantia (lei $n^{\circ} 9.514 / 97$, primeiras linhas). Porto Alegre: Sergio Antonio Fabris Editor, 1998, p. 43.

${ }^{292}$ BRESOLIN, Humberto Bara. Execução extrajudicial imobiliária: aspectos práticos. São Paulo: Atlas, 2013, p. 110.
} 
entender que estão cumpridas as exigências, ele próprio promove a intimação pessoal do devedor ${ }^{293}$. Caso não o encontre, deve certificar o fato e promover a intimação por edital.

Consumada a intimação, se o devedor purgar a mora dentro do prazo legal, o Oficial recebe o valor, desconta as despesas decorrentes do procedimento e, no prazo de três dias, deve entregar o montante ao devedor.

Se, contudo, não houver purgação da mora, o mesmo Oficial, de ofício, certifica o fato e consolida a propriedade em nome do credor fiduciário mediante averbação na matrícula do imóvel. É aqui, na consolidação da propriedade em nome do credor, que ocorre expropriação ${ }^{294}$, no caso, do direito de aquisição da propriedade do devedor, em atividade tipicamente substitutiva, capaz de qualificar este procedimento como executivo, conforme a acepção adotada.

Consolidada a propriedade, o fiduciário, no prazo de 30 dias, deve promover leilão para alienação do imóvel, primeiramente buscando ao menos o valor do bem, fixado em contrato, e, num segundo momento, buscando ao menos o valor da dívida, acrescido de despesas, prêmios de seguro e encargos legais. Caso não seja alcançado nem o valor da dívida no segundo leilão, a Lei prevê que o débito será considerado quitado e a propriedade se efetivará com o credor fiduciário.

Não há penhora - dispensada diante da consolidação direta da propriedade do bem previamente especificado e predisposto como garantia à execução ${ }^{295}$ - e nem previsão de qualquer meio de defesa ao devedor - pelo procedimento, sua única faculdade é adimplir com o débito ou acionar o judiciário por meio de ação autônoma.

\footnotetext{
${ }^{293}$ A lei autoriza, no $\S 3^{\circ}$ do artigo 26 , que o Oficial cumpra a diligência mediante delegação a preposto ou ao Cartório de Títulos e Documentos ou mesmo via Correios, por carta com aviso de recebimento.

${ }^{294}$ YOSHIKAWA, Eduardo Henrique de Oliveira. Execução extrajudicial e devido processo legal. São Paulo: Atlas, 2010, p. 40.

${ }^{295}$ TERRA, Marcelo. Alienação fiduciária de imóvel em garantia (lei no 9.514/97, primeiras linhas). Porto Alegre: Sergio Antonio Fabris Editor, 1998, p. 50; BRESOLIN, Humberto Bara. Execução extrajudicial imobiliária: aspectos práticos. São Paulo: Atlas, 2013, p. 132.
} 
Como os agentes envolvidos no procedimento são um Oficial de Cartório Extrajudicial - que, como se viu, exerce sua atividade em caráter privado - e um leiloeiro que, em que pese ser submetido a habilitação pública, nos termos do Decreto $n^{\circ}$ 21.981/32, exerce suas atividades, em regra, em regime privado -, pode-se classificar este procedimento como desjudicializado privado. A desjudicialização aqui prevista é integral, dada a possibilidade de toda a execução tramitar, do começo ao fim, sem interferência do Poder Judiciário.

Neste cenário, a exemplo do que se passa com o Decreto-Lei $n^{\circ}$ 70/66, a constitucionalidade do procedimento é bastante questionada, inclusive em termos praticamente idênticos aos tecidos para aquele rito, dada a semelhança dos procedimentos ${ }^{296}$.

No que concerne ao monopólio e inafastabilidade de jurisdição, a crítica é de que o inadimplemento do devedor configura lide, cuja solução deve se dar ou pela via da autocomposição ou pelo Poder Judiciário, já que não seria constitucionalmente possível atribuir função jurisdicional a autoridade administrativa - assim considerado o Oficial de Registro Público ${ }^{297}$. Neste mesmo sentido, seria inconstitucional a consolidação da propriedade do bem feita por ato do Oficial de Registro Público, de forma unilateral, sem prévia decisão judicial ${ }^{298}$.

Quanto à imparcialidade e naturalidade do agente executivo, a crítica aponta que, neste procedimento, uma vez que o próprio credor é quem conduz o processo executivo, inexiste terceiro intermediário imparcial, ficando o Oficial de Registro limitado a portar a intimação ao executado ${ }^{299}$. Esta condição, quando associada à crítica de que falta ao agente executivo capacidade para controlar o procedimento - o Oficial de Registro de Imóveis não

${ }^{296}$ SAAD, Renan Miguel. A alienação fiduciária sobre bens imóveis. Rio de Janeiro: Renovar, 2001, p. 279; BECKER, L.A. Contratos bancários: execuções especiais. São Paulo: Malheiros, 2002, p. 312.

${ }^{297}$ SANTOS, Ernane Fidélis dos. Alienação fiduciária de coisa imóvel. Revista Jurídica, Porto Alegre, vol. 47, n. 261, p.21-24, jul. 1999, p. 22.

${ }^{298}$ FUCCI, Paulo Eduardo. Aspectos da alienação fiduciária de coisa imóvel. Revista dos Tribunais, São Paulo, v. 753 , p. 848 , jul. 1998 , p. 82 .

${ }^{299}$ FABRÍCIO, Adroaldo Furtado. A alienação fiduciária de imóveis: aspectos processuais da Lei n. 9514/97. Disponível em < http://www.fabricioadvogados.com.br/artigos/art8.htm>. Acesso em 07 jul. 2015. 
teria autonomia para exercer eventual controle da existência e montante da dívida, por exemplo -, leva determinado segmento doutrinário a qualificar o procedimento da Lei $\mathrm{n}^{\circ}$ 9514/97 como modalidade de autotutela ${ }^{300}$.

Quanto ao contraditório, critica a doutrina, na esteira do posicionamento firmado perante o procedimento do Decreto-Lei $\mathrm{n}^{\circ} 70 / 66$, a inaplicabilidade do princípio, dada a exacerbação da unilateralidade, já que aqui também carecem oportunidades de defesa ao devedor $^{301}$, sendo a ele facultado apenas o pagamento da quantia devida ou, alternativamente, o acionamento do judiciário - sem qualquer meio específico para tanto, antes, durante ou depois da alienação do bem em leilão $0^{302}$ - ou da arbitragem, caso prevista em contrato ${ }^{303}$.

\subsubsection{O debate acerca da execução fiscal}

Conforme destacado ao longo do trabalho, a execução de créditos fiscais não é o foco da abordagem aqui desenvolvida. Em que pese também se tratar de execução por quantia e das linhas gerais aqui desenvolvidas poderem ser projetadas para o plano executivo fiscal, a transição não se daria sem adaptações, dadas as peculiaridades deste tipo de crédito e de seu titular, a exigir estudo dedicado.

\footnotetext{
300 MARTINS, Samir José Caetano. A execução extrajudicial de créditos do sistema de financiamento imobiliário. Revista eletrônica de direito processual, Rio de Janeiro, ano 2, vol. II, jan.-dez. 2008, p. 394; FABRÍCIO, Adroaldo Furtado. A alienação fiduciária de imóveis: aspectos processuais da Lei n. 9514/97. Disponível em < http://www.fabricioadvogados.com.br/artigos/art8.htm>. Acesso em 07 jul. 2015; YOSHIKAWA, Eduardo Henrique de Oliveira. Execução extrajudicial e devido processo legal. São Paulo: Atlas, 2010, p. 40. Este último autor, em contraponto ao primeiro, registra que, em termos de imparcialidade, não há diferenças entre o agente fiduciário do Decreto-Lei $n^{\circ} 70 / 66$ e o oficial de registro de imóveis da Lei $n^{\circ}$ 9514/97, carecendo a ambos, de igual modo, a isenção necessária.

${ }^{301}$ FABRÍCIO, Adroaldo Furtado. A alienação fiduciária de imóveis: aspectos processuais da Lei n. 9514/97. Disponível em < http://www.fabricioadvogados.com.br/artigos/art8.htm>. Acesso em 07 jul. 2015; BECKER, L.A. Contratos bancários: execuções especiais. São Paulo: Malheiros, 2002, p. 320.

302 TERRA, Marcelo. Alienação fiduciária de imóvel em garantia (lei $n^{\circ}$ 9.514/97, primeiras linhas). Porto Alegre: Sergio Antonio Fabris Editor, 1998, p. 54.

303 SAAD, Renan Miguel. A alienação fiduciária sobre bens imóveis. Rio de Janeiro: Renovar, 2001, p. 255.
} 
A despeito disso, não se pode ignorar que a execução fiscal é completamente centrada no Poder Judiciário ${ }^{304}$ e, conforme já apontado, é a principal protagonista de seu atual congestionamento $^{305}$. Em 2013, dos 95,12 milhões de processos que tramitaram pelo Poder Judiciário, 31,18 milhões eram execuções fiscais, equivalente a 32,7\% do total de processos e $72,3 \%$ do total de processos executivos. Ademais, na divisão estabelecida pelo Conselho Nacional de Justiça, é o tipo de processo com maior taxa total de congestionamento, pontuando $91 \%$ em 2013, ou seja, a cada 10 execuções fiscais, menos de uma é baixada no prazo de um ano.

O cenário, já há muito conhecido na comunidade jurídica, logo se tornou foco da atuação do Conselho Nacional de Justiça, culminando com diversas medidas para conhecimento aprofundado e tratamento da situação. O aprofundamento diagnóstico se operou em dois estudos principais sobre tempo, fluxo e custo da execução fiscal: um primeiro, encomendado junto ao IPEA - Instituto de Pesquisas Econômicas Aplicadas, e um segundo, apêndice do Relatório Justiça em Números de 2013 (ano-base 2012), especialmente dedicado ao tema, publicado como Sumário Executivo.

A partir de então, ganharam força medidas com foco na melhoria das execuções fiscais. Dentre elas, destaca-se aqui o ganho de força política de projetos de lei que já tramitavam com propostas de desjudicialização pública administrativa deste tipo de execução ${ }^{306}$.

${ }^{304}$ GODOY, Arnaldo Sampaio de Moraes. A execução fiscal administrativa no Direito Tributário comparado. Belo Horizonte: Fórum, 2009, p. 11; LOPES, Carlos Córtes Vieira. Breves considerações acerca do sistema tributário nos Estados Unidos da América. Escola da Advocacia-Geral da União Ministro Victor Nunes Leal Publicações da Escola da AGU, $1^{\circ}$ Curso de Introdução ao Direito Americano: Fundamental of US Law Course, Brasília, Ano III, n. 12, set.-out. 2011, p. 74.

${ }^{305}$ MENEZES, Nadja Lima. O direito fundamental à duração razoável do processo e a atuação judicial da administração pública brasileira como inspiração à adoção da súmula vinculante (stare decisis). Escola da Advocacia-Geral da União Ministro Victor Nunes Leal Publicações da Escola da AGU, $1^{\circ}$ Curso de Introdução ao Direito Americano: Fundamental of US Law Course, Brasília, Ano III, n. 12, set.-out. 2011, p. 287.

${ }^{306}$ A execução fiscal administrativa é modelo já utilizado em outros países, caso dos Estados Unidos, por exemplo, em que a administrative collection procedure, realizada em âmbito administrativo por agentes desta natureza, coexiste com a foreclosure action, procedimento judicializado. A segunda via, contudo, raramente é utilizada, haja vista que os agentes administrativos gozam de amplos poderes para recuperação do crédito 
Nesta seara enquadra-se o Projeto de Lei $\mathrm{n}^{\circ} 2412$, de novembro de 2007, de autoria do deputado Regis de Oliveira, que prevê a transferência da atividade executiva fiscal para a administração pública, retirando-a do Judiciário. A justificativa, além do acúmulo de processos desta sorte, é a ausência de complexidades na atuação ordinária do juiz nestes casos, limitando-se à mera aplicação da vontade da lei, tal como se dá na atividade administrativa.

Nesta proposta está prevista, ainda que indiretamente, a criação de uma estrutura similar à utilizada pelo Poder Judiciário junto à administração, com servidores especificamente voltados para a execução - caso, por exemplo, do agente fiscal, encarregado da notificação do executado e cumprimento do mandado executivo - de modo a viabilizar que o processo tramite, do início ao fim, no âmbito do próprio Fisco. Assim, da notificação do devedor, passando pelos atos de pesquisa de patrimônio, constrição, expropriação e até mesmo na resolução de lides incidentais ${ }^{307}$, tudo se passa no âmbito administrativo.

O acesso ao Judiciário resta eventual, apenas na hipótese de o executado optar pelo ajuizamento de embargos à execução. Esta via, como regra do Projeto, possui efeito suspensivo e é facultada ao executado nos 15 dias subsequentes à notificação, ocasião em que poderá alegar toda matéria que entender útil à sua defesa, conforme preconiza o artigo 24 do Projeto, sendo cabível também diante da arrematação ou adjudicação, em oportunidades taxativamente elencadas no artigo 27.

Trata-se de procedimento executivo integralmente desjudicializado ${ }^{308}$, que se vale da aludida desjudicialização administrativa, em que o papel de coordenação e determinação da execução é transferido para agentes públicos integrantes do corpo funcional da administração pública.

(LOPES, Carlos Córtes Vieira. Breves considerações acerca do sistema tributário nos Estados Unidos da América. Escola da Advocacia-Geral da União Ministro Victor Nunes Leal Publicações da Escola da AGU, $1^{\circ}$ Curso de Introdução ao Direito Americano: Fundamental of US Law Course, Brasília, Ano III, n. 12, set.out. 2011, p. 72).

307 O artigo 12 do Projeto prevê a possibilidade de exercício do contraditório no âmbito da própria administração sempre que o executado suscitar questões de ordem pública.

${ }^{308}$ RIBEIRO, Flávia Pereira. A desjudicialização da execução civil. São Paulo: Saraiva, 2013, p. 60. 
Também dentre as propostas de alteração do procedimento executivo fiscal está o projeto de lei no 5080/2009, de iniciativa do Poder Executivo, que, hoje, tramita em apenso ao já mencionado projeto de lei $n^{\circ} 2412 / 2007$.

A proposta contida no projeto de lei $n^{\circ} 5080 / 2009$, conta com maior respaldo técnico quando comparada com sua antecedente. Foi elaborada por comissão formada no âmbito do Conselho da Justiça Federal, composta por representantes da Associação de Juízes Federais e Procuradoria de Fazenda Nacional, sob a coordenação do Ministro do Superior Tribunal de Justiça e então Coordenador-Geral da Justiça Federal, Gilson Dipp, a partir do resultado de audiências públicas e anteprojetos acerca do tema.

Este procedimento mescla uma fase prévia e preparatória ${ }^{309}$, desjudicializada ${ }^{310}$, onde já ocorrem a interrupção da prescrição e atos de constrição patrimonial do devedor, aliado a uma segunda fase, posterior e judicializada, onde ocorrem a expropriação dos bens já constritos e ultimação da execução. O propósito é estabelecer um filtro às execuções fiscais que ascendem ao Poder Judiciário, evitando-se levar a juízo processos executivos com baixa expectativa de êxito, dada a escassez patrimonial do devedor ${ }^{311}$.

Pelo procedimento previsto no texto original do Projeto, descrito a partir do artigo $5^{\circ}$ do documento, o Fisco notifica o devedor para, em 60 dias, efetuar o pagamento, solicitar o parcelamento do débito ou garanti-lo por depósito, fiança ou seguro-garantia. Este ato de comunicação, em que pese ser denominado pela alcunha generalista de "notificação" pelo Projeto, tem características de citação, na medida em que a sua consumação já interrompe a prescrição - conforme $\$ 10$ do artigo $5^{\circ}$ do Projeto - e permite o ajuizamento de embargos à execução no prazo de 30 dias - conforme $\S 3^{\circ}$ e $5^{\circ}$ do artigo $23 .{ }^{312}$

\footnotetext{
${ }^{309}$ Denominada por Leonardo Greco de fase pré-processual (As garantias fundamentais do processo de execução fiscal. In: LOPES, João Batista; CUNHA, Leonardo Carneiro da (coord.). Execução civil (aspectos polêmicos). São Paulo: Dialética, 2005, p. 250).

${ }^{310}$ RIBEIRO, Flávia Pereira. A desjudicialização da execução civil. São Paulo: Saraiva, 2013, p. 62.

311 BRESOLIN, Humberto Bara. Execução extrajudicial imobiliária: aspectos práticos. São Paulo: Atlas, 2013, p. 66.

${ }^{312}$ Quando do início da fase judicial, há novo ato de comunicação do devedor, este sim, denominado no Projeto como citação, após o qual é novamente oportunizado o ajuizamento de embargos, conforme artigo 23, caput do Projeto.
} 
Após a notificação, artigo $7^{\circ}$ do Projeto prevê que, no prazo de 30 dias, fica facultada ao devedor a apresentação de defesa administrativa, restrita a discussões acerca do pagamento, compensação anterior à inscrição, matérias de ordem pública e quaisquer causas ensejadoras da nulidade do título. Esta oportunidade de contraditório não suspende o procedimento e não impede que a mesma discussão se estabeleça em juízo, caso a execução fiscal seja ajuizada.

Se porventura o devedor não atender a notificação ou não conseguir afastar a exigibilidade do crédito tributário, o $\S 6^{\circ}$, artigo $5^{\circ}$ autoriza que a Fazenda Pública efetue pesquisa do patrimônio do devedor. Para este fim, o artigo 16 do Projeto confere poder de requisição à Fazenda Pública perante pessoas jurídicas de direito privado e aos órgãos e entidades da administração pública.

Caso localize patrimônio disponível, oficial pertencente à própria Fazenda Pública 313 promove a mencionada constrição preparatória do patrimônio ${ }^{314}$, no limite do valor do débito, conforme artigo $9^{\circ}$ do Projeto. A este profissional incumbe, também, a avaliação dos bens constritos, a qual deverá constar no termo ou auto de constrição e cujo valor poderá ser objeto de impugnação administrativa do devedor no prazo de 15 dias, também sem prejuízo de nova discussão perante o juízo, nos termos do artigo 11 do Projeto.

Além da via administrativa, faculta-se ao devedor, no prazo de 15 dias, o ajuizamento de ação específica, denominada "impugnação aos atos de execução", que tem por objeto sustar ou adequar a constrição preparatória. Trata-se de procedimento sumário que não possui, em regra, efeito suspensivo.

\footnotetext{
$313 \mathrm{O}$ artigo 31 do Projeto prevê que estes oficiais da Fazenda Pública gozariam das mesmas prerrogativas atribuídas pelo Código de Processo Civil aos oficiais de justiça.

314 Já há quem denomine esta constrição como penhora administrativa (SZKLAROWSKY, Leon Frejda. À luz da Constituição, é possível instituir validamente a execução do crédito tributário por autoridade diversa da jurisdicional? Jus Navigandi, Teresina, ano 13, n. 1920, 3 out. 2008. Disponível em: <http://jus.com.br/artigos/11794>. Acesso em 05 mai. 2014).
} 
$\mathrm{O} \S 3^{\circ}$ do artigo $9^{\circ}$ do Projeto estipula que esta constrição administrativa mantém seus efeitos por 120 dias, em regra. Neste prazo, ela deverá ser convertida em penhora ou arresto por determinação de autoridade judiciária em âmbito de processo executivo fiscal ${ }^{315}$. Caso isso não ocorra, a constrição deixa de operar seus efeitos e os bens são liberados.

Caso não localize patrimônio disponível, os artigos 20 e 21 preveem que a Fazenda deixará de ajuizar a ação executiva e o processo administrativo ficará suspenso até que seja localizado patrimônio. Se, porventura, a ausência de patrimônio for verificada apenas na fase judicial - já que não é exigida a garantia total da dívida para ajuizamento da execução - o juiz pode determinar a baixa do processo e remessa dos autos ao órgão fazendário para realização de novas pesquisas. Em qualquer caso, se sobrevier o transcurso do prazo prescricional intercorrente, o fato pode ser reconhecido e decretado de ofício pela própria administração.

À luz dos parâmetros classificatórios estabelecidos, uma análise geral revela que esta proposta encerra procedimento misto, sem uma nítida preponderância de agentes judiciais ou administrativos na prática dos atos, haja vista a mescla de uma fase prévia desjudicializada e uma fase posterior, judicializada.

A existência de desjudicialização em ambas as propostas foi suficiente para que surgissem as primeiras críticas, voltadas, principalmente, à independência e imparcialidade dos agentes executivos, quer sejam aqueles que incumbidos de todo o processo executivo no Projeto $\mathrm{n}^{\circ}$ 2412/07 -, quer sejam os responsáveis pelo procedimento preparatório - no Projeto $\mathrm{n}^{\circ} 5080 / 2009$.

Em que pese a proposta, numa análise estanque do procedimento, revelar autêntico processo de desjudicialização administrativa de atos executivos - um agente pertencente à

\footnotetext{
315 A mencionada convolação das constrições em penhora ou arresto, se opera já com o despacho da inicial
} executiva, conforme previsão do $§ 7^{\circ}$, artigo 13 do Projeto. 
administração pública assumindo a responsabilidade pela prática de atos executivos -, há, em verdade, aparente confusão entre o agente executivo e o credor.

Isto porque o mesmo órgão que é credor - e, portanto, calcula o débito e o inscreve em Dívida Ativa, extraindo a respectiva certidão que vale como título executivo extrajudicial - passaria a ser responsável pelo processo de execução em si. Esta condição colocaria em cheque a imparcialidade exigida do agente incumbido da condução e realização do processo $^{316} \mathrm{e}$, por consequência, comprometeria a garantia de contraditório do executado.

Além disso, a prevalência, na administração brasileira, de uma cultura de estrita obediência hierárquica dos servidores públicos, muitas vezes em detrimento da própria legalidade, comprometeria a neutralidade exigível de um profissional atuante neste segmento $^{317}$.

Estas circunstâncias já deram ensejo a posições doutrinárias no sentido de que os modelos propostos se adequam à noção de autotutela, "grotescamente pintada com as cores do devido processo legal e do Estado de Direito para camuflar sua verdadeira origem e natureza" 318 .

Estes projetos seguem tramitando, cabendo observar que, em julho de 2015, o projeto principal já contava com 31 emendas, além de apensados outros dois Projetos de Lei tratando da mesma matéria - caso dos projetos de lei n ${ }^{\circ}$ 5081/2009 e 5082/2009 -, estando, na mesma época, em poder de Comissão Especial designada para elaboração de parecer.

\footnotetext{
316 SICA, Heitor Vitor Mendonça. Perspectivas atuais da "Teoria Geral do Processo". In: CARNEIRO, Athos Gusmão; CALMON, Petrônio (org.). Bases científicas para um renovado direito processual. 2 ed. Salvador: Juspodivm, 2009, p. 69; RIBEIRO, Flávia Pereira. A desjudicialização da execução civil. São Paulo: Saraiva, 2013, p. 64.

317 GRECO, Leonardo. As garantias fundamentais do processo de execução fiscal. In: LOPES, João Batista; CUNHA, Leonardo Carneiro da (coord.). Execução civil (aspectos polêmicos). São Paulo: Dialética, 2005 , p. 251.

318 YOSHIKAWA, Eduardo Henrique de Oliveira. Execução extrajudicial e devido processo legal. São Paulo: Atlas, 2010, p. 122.
} 


\subsection{Apontamentos do ordenamento estrangeiro}

Neste subitem será analisada a execução em alguns ordenamentos estrangeiros, no intento de identificar seus principais aspectos e a incidência de desjudicialização em cada um.

$\mathrm{Na}$ Europa, de onde advêm as principais inspirações do direito processual civil brasileiro, a despeito das iniciativas de unificação financeira, econômica e jurídica da União Europeia, com repercussões em tentativas de unificação de procedimentos executivos ${ }^{319} \mathrm{e}$ de incentivos à utilização de agentes executivos distintos de um juiz ${ }^{320}$, ainda não há

${ }^{319}$ LUCON, Paulo Henrique dos Santos. Eficácia das decisões e execução provisória. São Paulo: Editora Revista dos Tribunais, 2000, p. 71; PRÜTTING, Hanns. Fundamentos y tendencias actuales en el desarrollo del Derecho Procesal Civil Europeo. Revista de Processo, São Paulo, ano 35, $\mathrm{n}^{\text {o }}$ 190, dez. 2010, p. 89. A unificação de procedimentos executivos é particularmente relevante para a redução de barreiras na circulação de créditos entre países, notadamente os pequeno e médio porte (HESS, Burkhard. Different enforcement structures. In: VAN RHEE, C.H.; UZELAC, Alan (coord.). Enforcement and enforceability - tradition and reform. Antwerp, Oxford, Portland: Intersentia, 2010, p. 41), daí a preocupação na União Europeia neste sentido (UZELAC, Alan. Privatization of enforcement services - A step forward for countries in transition? In: VAN RHEE, C.H.; UZELAC, Alan (coord.). Enforcement and enforceability - tradition and reform. Antwerp, Oxford, Portland: Intersentia, 2010, p. 85). Para aprofundamentos sobre a questão, remete-se ao estudo de Xandra Kramer, que analisa minuciosamente as alterações promovidas nos ordenamentos alemão, holandês e inglês com vistas, se não à unificação, a uma aproximação dos ideais do bloco (Enhancing enforcement in the European Union. The European Order for payment procedure and its implementation in the Member States, particularly in Germany, the Netherlands and England. In: VAN RHEE, C.H.; UZELAC, Alan (coord.). Enforcement and enforceability - tradition and reform. Antwerp, Oxford, Portland: Intersentia, 2010, passim), bem como ao trabalho de Lurdes Mesquita, que enfrenta a questão do título executivo europeu, procedimento de certificação aprovado pelo Regulamento no 805/2004 do Parlamento Europeu e do Conselho e que tem por objetivo validar, com força executiva em nível comunitário, títulos executivos dos países-membros (MESQUITA, Lurdes. O título executivo europeu como instrumento de cooperação judiciária civil na União Europeia. Coimbra: Edições Almedina, 2012, passim).

${ }^{320}$ O Conselho da Europa, principal organização de direitos humanos do continente europeu, editou, por meio de sua Comissão para Eficiência da Justiça (CEPEJ), a recomendação n ${ }^{\circ}$ 17/2003, que definiu a facilitação da efetividade e economia das execuções como uma de suas prioridades e traçou normas gerais para que os estados-membros zelassem por tal preceito (CHARDON, Mathieu. How to implement common standards of enforcement law? In: VAN RHEE, C.H.; UZELAC, Alan (coord.). Enforcement and enforceability - tradition and reform. Antwerp, Oxford, Portland: Intersentia, 2010, p. 113). Dentre tais normas, o item IV trata, exclusivamente, dos agentes de execução. Em 2009, o mesmo órgão traçou diretrizes para a implementação da recomendação $\mathrm{n}^{\circ}$ 17/2003 nos estados-membros e, novamente, todo o quarto capítulo foi destinado ao agente de execução. Estas ideias se refletem, também, na União Europeia, que se preocupa com a simplificação e melhoria da execução civil desde o Tratado que constituiu a Comunidade Europeia, conforme artigo $65^{\circ}$, alínea 'a', terceiro travessão do mencionado diploma. Este escopo, ao ser refletido pela política norteadora do Bloco de estímulo à livre prestação de serviços - consubstanciada, entre outros, no artigo $49^{\circ}$ do Tratado -, fez com que essa atividade acabasse sendo vista também como solução para os problemas econômicos e de eficiência do judiciário (ALEMÃO, Ivan. A reforma da execução em Portugal. Disponível em 
uniformidade nos procedimentos de execução sequer entre os países-membros. Nesta esteira, a natureza dos agentes protagonistas na prática de atos executivos tampouco respeita uma única via, sendo possível encontrar diversas configurações de processos executivos sem que qualquer delas possa ser apontada como dominante ${ }^{321}$.

A despeito disso, a variedade de agentes preponderantes contempla as três modalidades executivas aqui seccionadas, podendo ser integrantes do Poder Judiciário casos do o gerichtsvollzieher na Alemanha, do secretario judicial na Espanha e do ufficiale giudiziario na Itália -, de um órgão administrativo - o Kronofogdemyndigheten na Suécia da iniciativa privada, em geral um profissional liberal oficialmente nomeado - o huissier de justice na França ou o agente de execução em Portugal.

Como se observa, de modo geral, estes países europeus apresentam uma valorização na atuação dos auxiliares judiciários na execução, quer sejam privados ou públicos, restringindo a atuação do juiz ao processo de conhecimento, apenas, ou até a aposição de uma fórmula executiva na sentença ${ }^{322}$, ou mesmo durante a execução, em alguns casos pontuais, incidentes cognitivos ou no controle de eventuais abusos ${ }^{323}$.

<http://jus.com.br/revista/texto/10000/reforma-da-execucao-em-portugal>. Acesso em 09 out. 2012). A influência pôde ser constatada já em 2010, em relatório da própria Comissão Europeia para Eficiência da Justiça (CEPEJ), cujo capítulo 13 aponta que, na maioria dos países adeptos de modelos desjudicializados, estes agentes de execução são privados.

${ }^{321}$ UZELAC, Alan. Privatization of enforcement services - A step forward for countries in transition? In: VAN RHEE, C.H.; UZELAC, Alan (coord.). Enforcement and enforceability - tradition and reform. Antwerp, Oxford, Portland: Intersentia, 2010, p. 85.

${ }^{322}$ As fórmulas executivas são simples certificados oficiais ou até mesmo comandos oficiais requeridos pelo interessado e emanados pelo juiz, nos títulos judiciais, ou pelo tabelião, nos títulos extrajudiciais, consignando a aptidão de um determinado documento para ser executado (DINAMARCO, Cândido Rangel. Execução civil. 8 ed. São Paulo: Malheiros, 2002, p. 96). A ideia é que, por meio da fórmula, os agentes executivos possam promover a execução sem necessidade de um exame aprofundado das causas que deram ensejo ao título executivo (GOLDSCHMIDT, James. Direito processual civil. Curitiba: Juruá, 2009, p. 447; RIBEIRO, Flávia Pereira. A desjudicialização da execução civil. São Paulo: Saraiva, 2013, p. 87; GRECO, Leonardo. O processo de execução: volume I. Rio de Janeiro: Renovar, 1999, p. 74).

${ }^{323}$ GRECO, Leonardo. O processo de execução: volume I. Rio de Janeiro: Renovar, 1999, p. 74 e 140. 
A seguir, analisaremos os principais modelos executivos adotados na Europa a partir da experiência dos países supracitados, sempre com foco nas iniciativas de desjudicialização de cada um.

\subsubsection{Modelos públicos judicializados}

Os modelos preponderantemente públicos judicializados ainda são amplamente utilizados ao redor do mundo. Seguem a tradição de execução com trâmite prioritário no âmbito do Poder Judiciário.

No continente americano, com destaque para a América do Sul, tais modelos podem ser verificados em países como Bolívia ${ }^{324}$, Colômbia ${ }^{325}$, México ${ }^{326}$, Paraguai $^{327}$ Peru $^{328}$,

324 NOVAES, Renato Rodrigues de. Direito processual civil boliviano. In: SOARES, Carlos Henrique; CARVALHO DIAS, Ronaldo Brêtas de (coord.). Direito Processual Civil Latino-Americano. Belo Horizonte: Arraes Editores, 2013, p. 100.

325 SICA, Heitor Vitor Mendonça. Direito processual civil colombiano. In: CRUZ E TUCCI, José Rogério (coord.). Direito processual civil americano contemporâneo. São Paulo: Lex Editora, 2010, p. 118-120; ARAÚJO, Fabrício Simão da Cunha. Direito processual civil colombiano. In: SOARES, Carlos Henrique; CARVALHO DIAS, Ronaldo Brêtas de (coord.). Direito Processual Civil Latino-Americano. Belo Horizonte: Arraes Editores, 2013, p. 178.

${ }^{326}$ CORRÊA. Fábio Peixinho Gomes. Direito processual civil mexicano. In: CRUZ E TUCCI, José Rogério (coord.). Direito processual civil americano contemporâneo. São Paulo: Lex Editora, 2010, p. 242-244; MENEZES, Rafael Filipe Fonseca de. Direito processual civil mexicano. In: SOARES, Carlos Henrique; CARVALHO DIAS, Ronaldo Brêtas de (coord.). Direito Processual Civil Latino-Americano. Belo Horizonte: Arraes Editores, 2013, p. 216.

327 ANDRADE, Marco Antonio de. Direito processual civil paraguaio. In: SOARES, Carlos Henrique; CARVALHO DIAS, Ronaldo Brêtas de (coord.). Direito Processual Civil Latino-Americano. Belo Horizonte: Arraes Editores, 2013, p. 254.

${ }^{328}$ OLIVEIRA, Guilherme José Braz de. Direito processual civil peruano. In: CRUZ E TUCCI, José Rogério (coord.). Direito processual civil americano contemporâneo. São Paulo: Lex Editora, 2010, p. 307; FREITAS, Gabriela Oliveira. Direito processual civil peruano. In: SOARES, Carlos Henrique; CARVALHO DIAS, Ronaldo Brêtas de (coord.). Direito Processual Civil Latino-Americano. Belo Horizonte: Arraes Editores, 2013, p. 267-268. 


\author{
Uruguai $^{329}$ e, com maior destaque, Argentina ${ }^{330}$, Costa Rica ${ }^{331}$ e Chile ${ }^{332}$. No continente \\ europeu, são os modelos empregados na Áustria, Dinamarca ${ }^{333}$, Suíça ${ }^{334}$, Grécia ${ }^{335}$ e \\ Inglaterra $^{336}$.
}

${ }^{329}$ COSTA, Carla Regina Clark da. Direito processual civil uruguaio. In: SOARES, Carlos Henrique; CARVALHO DIAS, Ronaldo Brêtas de (coord.). Direito Processual Civil Latino-Americano. Belo Horizonte: Arraes Editores, 2013, p. 285.

${ }^{330}$ A Argentina tem seu território dividido em 23 províncias e uma cidade autônoma, cada qual com autonomia legislativa, de modo que cada estado tem seu próprio regime processual. A despeito disso, a estrutura destes procedimentos é similar, sendo fortemente concentrada na atividade judicial (GOZAINI, Osvaldo Alfredo. Características del juicio ejecutivo argentino: problemas actuales. In: CADENAS, Manuel Cachón; JUNOY, Joan Picó. (coord.). La ejecución civil: problemas actuales. Barcelona: Atelier Libros Jurídicos, 2008, p. 327329). Tomando-se por base o procedimento previsto no Codigo Procesal Civil Y Comercial De La Nacion, tem-se que a execução atende a três fases: uma primeira, que compreende o ajuizamento da demanda, a intimação para pagamento, a penhora e a citação para defesa; uma segunda, destinada à oposição do executado, com respectiva instrução probatória, sentença e recursos e uma terceira, em que se cumpre eventual sentencia de remate, em que são adotados os trâmites para alienação dos bens penhorados. Na primeira fase, atuam tanto juiz quanto oficial de justicia, este funcionário público judicial, vinculado à Oficina de Mandamientos y Notificaciones, repartição submetida à superintendência da Corte Suprema. Sempre sob supervisão judicial, atua na intimação para pagamento, penhora, a seu juízo, até o valor do débito. A segunda é tipicamente cognitiva, de protagonizada pelo juiz. A terceira, em que pese ser novamente protagonizada pelo juiz, conta com leiloeiro privado, designado pelo juiz ou pelas partes, em desjudicialização privada incidental, à similaridade do que se passa no Brasil. (PALACIO, Lino Henrique. Manual de derecho procesal civil. 20 ed. Buenos Aires: AbeledoPerrot, 2011, passim).

${ }^{331}$ A execução costarricense sofreu grande reforma em 2007 com a Lei ${ }^{\circ} 8.624 / 07$, Ley de cobro judicial, que instituiu duas formas de execução, a depender do tipo de direito: por meio um processo monitório e por meio do processo de execução. Em qualquer caso ela ocorre preponderantemente em âmbito judicial. Todavia, no processo de execução, caso seja necessária penhora, o juiz designa um ejecutor (COELHO, Gláucia Mara. Direito processual civil costarriquenho. In: CRUZ E TUCCI, José Rogério (coord.). Direito processual civil americano contemporâneo. São Paulo: Lex Editora, 2010, p. 156-160), já fixando seus honorários. Estes ejecutores são equiparáveis aos auxiliares eventuais da Justiça brasileiros, profissionais privados, atuando em livre iniciativa, podendo ser designados mediante inscrição - tudo nos termos do Reglamento para regular la función de las y los intérpretes, traductores, peritos y ejecutores en el poder judicial aprobado mediante sesión de Corte Plena $N^{\circ}$ 10-12 del 12 de marzo del 2012 - com alguma liberdade para atuar - pode, por exemplo, designar depositário para o bem penhorado - e sujeito a controle judicial e disciplinar. A hipótese configura desjudicialização privada incidental em um processo preponderantemnte judicializado.

$332 \mathrm{O}$ direito processual civil chileno é regido, até os dias de hoje, com algumas reformas voltadas à agilização de procedimentos (HERNÁNDEZ, Nancy de la Fuente. Desjudicialización y procedimiento de realización de bienes embargados. In: CADENAS, Manuel Cachón; JUNOY, Joan Picó. (coord.). La ejecución civil: problemas actuales. Barcelona: Atelier Libros Jurídicos, 2008, p. 471), pelo Código de Procedimiento Civil, datado de 1903, cuja execução, tratada no Livro III do diploma, segue um rito preponderantemente judicializado (LEONEL, Ricardo de Barros. Direito processual civil chileno. In: CRUZ E TUCCI, José Rogério (coord.). Direito processual civil americano contemporâneo. São Paulo: Lex Editora, 2010, p. 69 e 91). Todavia, tramita desde 2012 um projeto de lei para criação de um novo Código de Processo Civil (Boletín 8197-07). Este projeto previa, em sua concepção original apresentada perante a Câmara de Deputados, em seu Livro IV, a partir do artigo 422, uma execução desjudicializada, toda conduzida por um oficial de ejecución, profissional cuja regulamentação se daria em momento posterior, mas que seria responsável pela maior parte dos atos, inclusive e notadamente aqueles atinentes à penhora, estando sujeito a controle judicial, o que suscitou 
Para desenvolvimento do tópico, o destaque será para os ordenamentos de maior influência ao direito brasileiro que são adeptos do modelo preponderantemente público judicializado, quais sejam, Alemanha, Itália e Espanha.

debates na doutrina chilena (v. PAVEZ, Macarena Vargas. Hacia la desjudicialización de la ejecución civil. Revista chilena de derecho, Santiago, v. 40, $\mathrm{n}^{\circ}$ 01, abr. 2013, Disponível em <http://www.scielo.cl/scielo.php?script=sci_arttext\&pid=S0718-34372013000100006\&lng=es\&nrm=iso>. Acesso em $1^{\circ}$ jul. 2014, passim). Todavia, ainda na Câmara dos Deputados a iniciativa foi rechaçada por, dentre outros argumentos lançados na $21^{\text {a }}$ Sessão daquela casa, ocorrida em 7 de maio de 2014, discrepâncias e incertezas quanto à figura do oficial, notadamente no que concerne à sua natureza e forma de atuação. O projeto foi aprovado sem disposições acerca do processo executivo e, atualmente, está em segunda tramitação no Senado (v. tramitação e documentos disponíveis junto à Câmara dos Deputados em < https://www.camara.cl/pley/pley_detalle.aspx?prmID=8596> e junto ao Senado em < http://www.senado.cl/appsenado/templates/tramitacion/index.php>, acessados em 15 nov. 2014).

${ }^{333}$ HESS, Burkhard. Different enforcement structures. In: VAN RHEE, C.H.; UZELAC, Alan (coord.). Enforcement and enforceability - tradition and reform. Antwerp, Oxford, Portland: Intersentia, 2010, p. 46.

${ }^{334} \mathrm{Na}$ Suíça, em que pese haver um agente judiciário conduzindo a execução, ele é livremente nomeado pelos cantões e sua configuração não atende, formalmente, aos requisitos de uma corte de execução (MORAES, José Rubens de. Direito processual civil suíço. In: CRUZ E TUCCI, José Rogério (coord.). Direito processual civil europeu contemporâneo. São Paulo: Lex Editora, 2010, p. 377).

${ }^{335}$ A Grécia adota modelo similar ao espanhol explicado adiante, com os atos executivos judicializados, porém distantes do juiz, concentrados em um funcionário da corte com função de direção do processo. O juiz somente é acionado para controle de legalidade do processo (OLIVEIRA, Guilherme José Braz de. Direito processual civil grego. In: CRUZ E TUCCI, José Rogério (coord.). Direito processual civil europeu contemporâneo. São Paulo: Lex Editora, 2010, p. 176).

${ }^{336} \mathrm{O}$ modelo inglês de execução por quantia é um tanto peculiar. $\mathrm{O}$ exequente dispõe de várias formas para satisfação de seu crédito (SIME, Stuart. A practical approach to civil procedure. 5 ed. Oxford: Oxford University Press, 2002, p. 479; CRUZ E TUCCI, José Rogério. Direito processual civil inglês. In: CRUZ E TUCCI, José Rogério (coord.). Direito processual civil europeu contemporâneo. São Paulo: Lex Editora, 2010, p. 240). Nas ocasiões em que ele opta pela penhora de bens do executado, as Hight Courts ou County Courts expedem, respectivamente, um writ of control ou warrants control, ambos com a função de conferir poderes aos enforcement agents (ANDREWS, Neil; TURNER, Robert. The system of enforcement of civil judgments in England. In: VAN RHEE, C.H.; UZELAC, Alan (coord.). Enforcement and enforceability - tradition and reform. Antwerp, Oxford, Portland: Intersentia, 2010, p. 130), profissionais privados, que atuam em livre competição entre si, regulados, licenciados e qualificados pela Security Industry Authority (HESS, Burkhard. Different enforcement structures. In: VAN RHEE, C.H.; UZELAC, Alan (coord.). Enforcement and enforceability - tradition and reform. Antwerp, Oxford, Portland: Intersentia, 2010, p. 48) - organização britânica que tem, especificamente, a função de regulamentar atividades privadas -, com liberdade para escolher o meio que entender mais adequado para recuperação do crédito, podendo, inclusive, solicitar amparo policial (TURNER, Robert. A model for an enforcement regime. The High Court enforcement officers of the Supreme Court of England and Wales. In: VAN RHEE, C.H.; UZELAC, Alan (coord.). Enforcement and enforceability - tradition and reform. Antwerp, Oxford, Portland: Intersentia, 2010, p. 143-144). Em que pese existirem estes agentes privados, não se pode dizer que o modelo inglês seja preponderantemente privado, haja vista que suas atuações são, pontualmente, na penhora e alienação de bens. Os demais atos, inclusive os outros meios de execução, como as third party debt orders e as charging orders (ANDREWS, Neil. O moderno processo civil: formas judiciais e alternativas de resolução de conflitos na Inglaterra. 2 ed. São Paulo: RT, 2012, p. 300-301), dispensam a atuação dos enforcement agents, podendo tramitar inteiramente diante do juízo. 
Nos dois primeiros, Alemanha e Itália, o processo executivo começa com a provocação, pela parte, do gerichtsvollzieher ou do ufficiale giudiziario, respectivamente (artigos 137, 479, 484, 488, 513 do Codice di Procedura Civile e artigo 753 do Zivilprozessordnung), agentes públicos distintos do juiz, mas também integrantes do quadro funcional do Poder Judiciário.

Já na Espanha (artigo 551 da Ley Enjuiciamiento Civil), a iniciativa do processo executivo ainda se dá perante o juiz, mas a prática dos atos é dividida com o secretario judicial, este também integrante do Judiciário.

Ainda que adotantes de um mesmo modelo executivo judicializado, os agentes encarregados da execução em cada um destes países gozam de diferentes prerrogativas e graus de autonomia, assim como os procedimentos têm suas peculiaridades em termos de desjudicialização, razões pelas quais se afiguram cabíveis análises individualizadas dos respectivos ritos.

\subsubsection{Alemanha}

Na Alemanha, a execução judicial é o meio à disposição do exequente e, em regra, não é da competência do órgão responsável pelo processo de conhecimento ${ }^{337}$. Há, aliás, diversos agentes com atribuições executivas ${ }^{338}$, sendo eles, principalmente, o oficial de execução (gerichtsvollzieher), o tribunal de execução (vollstreckungsgericht) e o secretário judicial ou oficial de justiça (rechtspfleger).

\footnotetext{
${ }^{337}$ BENEDUZI, Pedro. Introdução ao processo civil alemão. Salvador: Editora Juspodivm, 2015, p. 137.

338 HESS, Burkhard. Different enforcement structures. In: VAN RHEE, C.H.; UZELAC, Alan (coord.). Enforcement and enforceability - tradition and reform. Antwerp, Oxford, Portland: Intersentia, 2010, p. 45.
} 
O Oficial de Execução (gerichtsvollzieher) é um funcionário público ${ }^{339}$ de nível médio, atrelado ao Poder Judiciário ${ }^{340}$, mais especificamente ao tribunal distrital (Amtsgericht) onde deva correr a execução, este originariamente competente, conforme seção 740 do Zivilprozessordnung (ZPO). Em regra, é o Oficial de Execução quem deve ser acionado para promovê-la ${ }^{341}$, sendo mais ou menos atuante a depender dos tipos de prestação almejada e bem perseguido.

Para as obrigações de pagar quantia, sua atuação se dá de modo mais intenso quando há persecução de bens móveis distintos de créditos ou direitos ${ }^{342}$.

Nestes casos, o Oficial de Execução tem ampla atuação, ficando encarregado da realização dos atos de notificação, citação e da maioria das medidas executivas, como apreensão e entrega de coisas, penhora e leilão, sendo-lhe facultado o uso de força pública quando necessário. Tem atribuições, também, para parcelar o débito, ficando encarregado do recebimento das parcelas, e para obter, junto ao devedor, sua declaração de bens passíveis

339 A doutrina diverge quanto à natureza jurídica deste agente. Em que pese prevalecer o entendimento aqui adotado, de se tratar de agente puramente público, uma vez que é vinculado e remunerado pelo erário (PRADILlO, Juan Carlos Ortiz; RAGONE, Álvaro J. Perez. Código Procesal Civil Alemán (ZPO). Montevidéu: Konrad Adenauer Stiftung, 2006, p. 137; GOLDSCHMIDT, James. Direito processual civil. Curitiba: Juruá, 2009, p. 132), há quem extraia da seção 753 da Zivilprozessordnung (ZPO) a interpretação de que o Oficial de Execução atuaria como mandatário do credor e, por isso, teria natureza jurídica híbrida, pública e privada (GRECO, Leonardo. O processo de execução: volume I. Rio de Janeiro: Renovar, 1999, p. 75; RIBEIRO, Flávia Pereira. A desjudicialização da execução civil. São Paulo: Saraiva, 2013, p. 93). Independentemente da corrente adotada, há de se ressaltar que o gerichtsvollzieher é remunerado por salário, pago pelo erário, e complementado por honorários recebidos em razão da execução (HESS, Burkhard. Different enforcement structures. In: VAN RHEE, C.H.; UZELAC, Alan (coord.). Enforcement and enforceability tradition and reform. Antwerp, Oxford, Portland: Intersentia, 2010, p. 47).

340 PRADILlO, Juan Carlos Ortiz; RAGONE, Álvaro J. Perez. Código Procesal Civil Alemán (ZPO). Montevidéu: Konrad Adenauer Stiftung, 2006, p. 137.

${ }^{341}$ Conforme o item 1 da seção 753 da ZPO "Unless the compulsory enforcement is assigned to the courts, it will be implemented by court-appointed enforcement officers who are to effect it on behalf of the creditor.".

${ }^{342}$ A escolha do bem a ser constrito cabe ao exequente, desde que respeitados os limites impostos pelo título executivo e a proporcionalidade na invasão do patrimônio do devedor, tutelada de diversas formas na legislação como, por exemplo, a da seção 811 do ZPO, que traz um rol de bens para os quais é vedada a penhora (BENEDUZI, Pedro. Introdução ao processo civil alemão. Salvador: Editora Juspodivm, 2015, p. 140). 
de penhora ${ }^{343}$, espécie de juramento, previsto na seção 807 do ZPO, que pode servir para decretação de insolvência do devedor ${ }^{344}$.

Sua responsabilidade é a mesma atribuída aos demais servidores públicos ${ }^{345}$, devendo prestar contas de sua atuação, inclusive com a lavratura de atas das atividades executivas realizadas $^{346}$. Deve, ainda, se estabelecer em um escritório, cujas expensas podem ser incluídas no crédito perseguido ${ }^{347}$.

Pelo procedimento, recebendo o requerimento executivo, o Oficial Executivo avalia se estão presentes os requisitos do título executivo e da cláusula executiva. Superada esta etapa, havendo bens, o Oficial efetua a penhora e a registra em ata, momento a partir do qual o devedor é ouvido ${ }^{348}$. A ele são garantidos três mecanismos de defesa: reclamação contra a cláusula executiva, perante o tribunal que a concedeu, por falta ou defeito do título executivo, por inadmissibilidade da execução ou qualquer nulidade; ação de defesa contra a execução, apresentada na primeira instância, a fim de desfazer os fundamentos fáticos da sentença e; reclamação, perante o tribunal da execução, contra o modo ou forma dos atos executivos praticados pelo agente de execução ou pelo oficial de justiça ${ }^{349}$.

Caso a execução não seja obstada de nenhuma forma, o Oficial avalia o bem penhorado e o aliena. Esta alienação será, em regra, uma hasta pública. Todavia, a seção 825 do ZPO permite ao Oficial de Execução que, a pedido do credor ou do devedor, realize a venda de modo diverso ${ }^{350}$, existindo aqui até mesmo a possibilidade de que a venda seja

${ }^{343}$ KENNETT, Wendy. The enforcement of judgements in Europe. Oxford: Oxford University Press, $2000, \mathrm{p}$. 81.

${ }^{344}$ GRECO, Leonardo. A crise do processo de execução. In: FIUZA, César Augusto de Castro; SÁ, Maria de Fátima Freire de; DIAS, Ronaldo Brêtas C. Temas atuais de Direito Processual Civil. Belo Horizonte: Del Rey, 2001, p. 217.

${ }^{345}$ GOLDSCHMIDT, James. Direito processual civil. Curitiba: Juruá, 2009, p. 132.

346 RIBEIRO, Flávia Pereira. A desjudicialização da execução civil. São Paulo: Saraiva, 2013, p. 94.

${ }^{347}$ KENNETT, Wendy. The enforcement of judgements in Europe. Oxford: Oxford University Press, 2000, p. 81.

${ }^{348}$ RIBEIRO, Flávia Pereira. A desjudicialização da execução civil. São Paulo: Saraiva, 2013, p. 94.

${ }^{349}$ Ibidem, p. 95.

${ }^{350}$ BENEDUZI, Pedro. Introdução ao processo civil alemão. Salvador: Editora Juspodivm, 2015, p. 143. 
realizada por intermediário particular, em abertura procedimental para que o ato seja realizado de forma desjudicializada.

Se o produto da alienação não for suficiente para sanar o débito, o Oficial requisita a supracitada declaração de bens do devedor. Caso haja novos bens, procede a novas penhoras e alienações até a satisfação do débito ${ }^{351}$.

Se, todavia, não houver bens bastantes para satisfação do crédito, o processo é extinto, restando garantido ao credor o direito de ajuizar nova execução tão logo haja patrimônio disponível ${ }^{352}$.

Paralelamente ao Oficial, atua o Tribunal de Execução (vollstreckungsgericht). É de sua incumbência a execução de pagar quantia que recair sobre créditos e direitos patrimoniais, como nos casos que implicam leilão e administração de bens imóveis ${ }^{353}$. Nestes casos ele assume as funções do oficial de execução, de modo que atos como a penhora e a distribuição do produto da arrematação entre credores se dão mediante decisões suas ${ }^{354}$. A ele cabe, ainda, decidir eventual reclamação proposta contra o procedimento adotado pelo Oficial de Execução, conforme seção 760 do ZPO.

Nestes casos em que tem de exercer atividade executiva, as diligências são cumpridas, geralmente, pelo secretário judicial ou oficial de justiça (rechtspfleger) ${ }^{355}$, também servidor público, atrelado ao Poder Judiciário.

\subsubsection{Itália}

\footnotetext{
${ }^{351}$ RIBEIRO, Flávia Pereira. A desjudicialização da execução civil. São Paulo: Saraiva, 2013, p. 94-95.

352 Ibidem, p. 95-96.

353 PRADILlO, Juan Carlos Ortiz; RAGONE, Álvaro J. Perez. Código Procesal Civil Alemán (ZPO). Montevidéu: Konrad Adenauer Stiftung, 2006, p. 90.

${ }^{354}$ BENEDUZI, Pedro. Introdução ao processo civil alemão. Salvador: Editora Juspodivm, 2015, p. 143.

${ }^{355}$ GOLDSCHMIDT, James. Direito processual civil. Curitiba: Juruá, 2009, p. 139.
} 
Na Itália, a execução enquanto atividade jurisdicional é, ao menos a princípio, monopolizada pelo Estado e reservada ao juiz ${ }^{356}$. Dentro da função jurisdicional, o processo executivo é coordenado e supervisionado por um juiz e conta com o oficial de justiça (ufficiale giudiziario) como importante agente auxiliar.

O oficial de justiça é funcionário público ${ }^{357}$ que, a despeito de ser remunerado por emolumentos pagos pela parte, não atua como seu mandatário, já que é integrante do Tribunal e está submetido às garantias e restrições aplicáveis aos agentes públicos judiciários, como, por exemplo, os deveres de imparcialidade e as hipóteses de abstenção e recusa de suas atuações ${ }^{358}$.

Estes profissionais exercem atividades como o poder-dever de verificar os pressupostos de legitimidade da execução, procurar, na própria pessoa do devedor e nos imóveis a ele pertencentes, patrimônio penhorável do devedor, e, conforme escolha do credor, penhorar bens móveis, imóveis ou crédito ${ }^{359}$, com uso de força, se necessário ${ }^{360}$, podendo ainda exigir do devedor, a exemplo do oficial executivo alemão, declaração de bens, cuja omissão ou falsidade configuram crime ${ }^{361}$. Atuam sob constante supervisão do juiz $^{362}$ e são civilmente responsáveis pelos atos que, sem justo motivo, deixarem de praticar, assim como pelos atos nulos, praticados com dolo ou culpa grave ${ }^{363}$.

\footnotetext{
356 PICARDI, Nicola. Manuale del Processo Civile. 3 ed. Milão: Giuffrè Editore, 2013, p. 589-590.

357 SILVESTRI, Elisabetta. The devil is in the details: remarks on Italian enforcement procedures. In: VAN RHEE, C.H.; UZELAC, Alan (coord.). Enforcement and enforceability - tradition and reform. Antwerp, Oxford, Portland: Intersentia, 2010, p. 208-209.

${ }^{358}$ CHIOVENDA, Giuseppe. Instituições de direito processual civil. 4 ed. Campinas: Bookseller Editora, 2008, p. 603-605; CARNELUTTI, Francesco. Instituições do Processo Civil - Volume I. São Paulo: Classic Book, 2000, p. 244-255; GRECO, Leonardo. O processo de execução: volume I. Rio de Janeiro: Renovar, 1999, p. 57.

${ }^{359}$ LUISO, Francesco P. Diritto processuale civile - Il processo executivo. 7 ed. Milão: Giuffrè Editore, 2013, p. 74, 78 e 81 , respectivamente.

${ }^{360}$ GRECO, Leonardo. O processo de execução: volume I. Rio de Janeiro: Renovar, 1999, p. 57-58.

${ }^{361}$ LUISO, Francesco P. Diritto processuale civile - Il processo executivo. 7 ed. Milão: Giuffrè Editore, 2013, p. 73.

${ }^{362}$ SILVESTRI, Elisabetta. The devil is in the details: remarks on Italian enforcement procedures. In: VAN RHEE, C.H.; UZELAC, Alan (coord.). Enforcement and enforceability - tradition and reform. Antwerp, Oxford, Portland: Intersentia, 2010, p. 209.

${ }^{363}$ RIBEIRO, Flávia Pereira. A desjudicialização da execução civil. São Paulo: Saraiva, 2013, p. 102.
} 
O procedimento executivo apresenta três fases. Uma primeira, preliminar, em que o credor apresenta o título, acompanhado de uma requisição de pagamento - o chamado precetto - dos quais o devedor é intimado pessoalmente por um oficial de justiça. Não havendo pagamento, o oficial, a pedido do exequente, sem qualquer intervenção do juiz, passa a praticar medidas constritivas, notadamente a penhora ${ }^{364}$, nos termos dos artigos 491 e 492 do Codice di Procedura Civile, dando início à segunda fase, expropriatória.

Realizada a constrição, o oficial de justiça entrega o auto de penhora na secretaria de execução, oportunidade em que serão formados os autos executivos e, somente então, designado o juiz da execução. O juiz, então, passa a atuar ativamente. Primeiramente ouve as partes acerca de requerimento de assegnazione ou de vendita formulado pelo credor, podendo dispor acerca da modalidade de expropriação. Finalmente, abre-se a fase satisfativa, pela qual ocorre a distribuição dos proventos coordenada pelo juiz ${ }^{365}$.

O artigo 591-Bis do Codice di Procedura Civile permite que a operação de venda do bem penhorado, a exemplo do que se dá no Brasil, seja delegada, pelo juiz da execução, a um notário local, um advogado ou a um contador, aqui registrada uma das raras desjudicializações incidentais no procedimento preponderantemente judicializado italiano. Sua, função, em verdade, é até mais ampla que a do leiloeiro brasileiro, atuando desde a avaliação dos bens penhorados, passando pela publicação do edital de hasta pública e todos os demais atos que se fizerem necessários até a definitiva alienação ${ }^{366}$. O mesmo se dá para a alienação de bens imóveis, que pode ser delegada, além dos profissionais acima elencados, a uma instituição privada, credenciada junto ao juízo, conforme artigos 534 e 534-Bis do Codice di Procedura Civile.

${ }^{364}$ DINAMARCO, Cândido Rangel. Execução civil. 8 ed. São Paulo: Malheiros, 2002, p. 101.

365 PICARDI, Nicola. Manuale del Processo Civile. 3 ed. Milão: Giuffrè Editore, 2013, p. 614.

${ }^{366}$ POZZA, Pedro. Art. 706. In: ALVARO DE OLIVEIRA, Carlos Alberto (coord.). A nova execução de títulos extrajudiciais. Rio de Janeiro: Forense, 2006, p. 153-154. 
Este procedimento executivo somente pode ser obstado pelo devedor por meio de oposição, ação autônoma análoga aos embargos do devedor ${ }^{367}$, regulamentada nos artigos 615 e seguintes do Codice di Procedura Civile.

\subsubsection{Espanha}

A execução espanhola, tratada pela Ley de Enjuiciamiento Civil a partir de seu livro terceiro $^{368}$, teve um modelo executivo estritamente centralizado e atrelado à coordenação e atuação do juiz ${ }^{369}$. Todavia, diagnóstico de que a execução era o tipo de processo civil com maior lentidão na justiça espanhola ${ }^{370}$, impulsionou mudanças que culminaram com o advento da Lei $n^{\circ} 13 / 2009$ e da Lei Orgânica ${ }^{\circ}$ 1/2009, que criaram a Nova Oficina Judicial e redistribuíram as funções e responsabilidades dos agentes judiciários ${ }^{371}$.

Neste contexto, os secretarios judiciales - funcionários públicos com formação jurídica $^{372}$, pertencentes à administração da justiça - passaram a praticar atos que até então eram de atribuição do juiz, tais como, no campo da execução, a extinção do feito por acordo, desistência, prescrição ou satisfação do débito ${ }^{373}$, o decreto de quais medidas executivas serão $\operatorname{adotadas}^{374}$, ordem para que entidades financeiras, órgãos e registros públicos e pessoas físicas e jurídicas indicadas pelo exequente forneçam relação de bens ou direitos do

\footnotetext{
${ }^{367}$ GRECO, Leonardo. O processo de execução: volume I. Rio de Janeiro: Renovar, 1999, p. 66.

368 CADENAS, Manuel Cachón. Apuntes de ejecución procesal civil. Barcelona: Universitat Autònoma de Barcelona, 2011, p. 8.

369 TREPAT, Cristina Riba. La investigación judicial en la nueva ejecución civil. In: CADENAS, Manuel Cachón; JUNOY, Joan Picó. (coord.). La ejecución civil: problemas actuales. Barcelona: Atelier Libros Jurídicos, 2008; HESS, Burkhard. Different enforcement structures. In: VAN RHEE, C.H.; UZELAC, Alan (coord.). Enforcement and enforceability - tradition and reform. Antwerp, Oxford, Portland: Intersentia, 2010, p. 44; GRECO, Leonardo. O processo de execução: volume I. Rio de Janeiro: Renovar, 1999, p. 103.

${ }^{370}$ FUENTE, Maria Consuelo Ruiz de la. El derecho constitucional a la ejecución de sentencias firmes. In: CADENAS, Manuel Cachón; JUNOY, Joan Picó. (coord.). La ejecución civil: problemas actuales. Barcelona: Atelier Libros Jurídicos, 2008, p. 21.

${ }^{371}$ RIBEIRO, Flávia Pereira. A desjudicialização da execução civil. São Paulo: Saraiva, 2013, p. 108-109.

372 KENNETT, Wendy. The enforcement of judgements in Europe. Oxford: Oxford University Press, 2000, p. 79.

${ }^{373}$ RIBEIRO, Flávia Pereira. A desjudicialização da execução civil. São Paulo: Saraiva, 2013, p. 109.

${ }^{374}$ CADENAS, Manuel Cachón. La ejecución procesal civil. Barcelona: Atelier Libros Juridicos, 2014, p. 62.
} 
executado $^{375}$, dentre outras, assumindo a maioria dos atos neste tipo de feito ${ }^{376}$, exceto o recebimento da inicial e a resolução de eventual oposição do executado, ainda a cargo do juiz 377 .

Estes atos de incumbência do secretario judicial podem ser decretos - quando define a adoção de uma providência - ou diligências - quando dá impulso ao processo - ${ }^{378} \mathrm{e}$ todos eles são recorríveis ao juiz ${ }^{379}$.

A execução espanhola se faz mediante demanda, sujeita a juízo de admissibilidade ${ }^{380}$, e inicia-se com o despacho de admissão da inicial ${ }^{381}$, dado pelo juiz, como uma ordem geral de execução, nos termos do item 1 do artigo 551 da Ley de enjuiciamiento civil $^{382}$.

A ele se segue a possibilidade de o secretário escolher qual a medida executiva mais adequada, podendo, inclusive, exigir do executado uma manifestação sobre os bens que dispõe, conforme item 3 do mesmo dispositivo ${ }^{383}$. A liberdade de atuação do secretario se

375 CADENAS, Manuel Cachón. Apuntes de ejecución procesal civil. Barcelona: Universitat Autònoma de Barcelona, 2011, p. 35.

376 Juan F. Garnica Martín indica a existência de uma competência residual ao secretario judicial, sendo dele a atribuição para praticar todos os atos que não tiverem designação específica a outro agente (Reparto de funciones entre juez y secretario em la ejucucion. Disponível em <http://www.cejmjusticia.es/cej_dode/doc_users/pdf/nueva_oficina_judicial/ejecucion_civil/REPARTO_DE_FUNCIONES.p df >. Acesso em 18 ago. 2015, p. 8).

377 RIBEIRO, Flávia Pereira. A desjudicialização da execução civil. São Paulo: Saraiva, 2013, p. 110.

378 Ibidem, p. 109.

${ }^{379}$ CADENAS, Manuel Cachón. La ejecución procesal civil. Barcelona: Atelier Libros Juridicos, 2014, p. 64. 380 SICA, Heitor Vitor Mendonça. Direito processual civil espanhol. In: CRUZ E TUCCI, José Rogério (coord.). Direito processual civil europeu contemporâneo. São Paulo: Lex Editora, 2010, p. 99.

${ }^{381}$ Em seu juízo de admissibilidade o juiz apenas verifica os pressupostos processuais, os requisitos para que o documento levado à execução tenha força executiva e se os atos executivos solicitados pela parte são adequados ao tipo de obrigação titularizada pelo exequente (CADENAS, Manuel Cachón. Apuntes de ejecución procesal civil. Barcelona: Universitat Autònoma de Barcelona, 2011, p. 24).

382 "Presentada la demanda ejecutiva, el Tribunal, siempre que concurran los presupuestos y requisitos procesales, el título ejecutivo no adolezca de ninguna irregularidad formal y los actos de ejecución que se solicitan sean conformes con la naturaleza y contenido del título, dictará auto conteniendo la orden general de ejecución y despachando la misma.".

383 "Dictado el auto por el Juez o Magistrado, el Secretario judicial responsable de la ejecución, en el mismo día o en el siguiente día hábil a aquél en que hubiera sido dictado el auto despachando ejecución, dictará decreto en el que se contendrán: $1^{\circ}$ Las medidas ejecutivas concretas que resultaren procedentes, incluido si fuera posible el embargo de bienes; $2^{\circ}$ Las medidas de localización y averiguación de los bienes del ejecutado que procedan, conforme a lo previsto en los artículos 589 y 590 de esta ley; $3^{\circ} \mathrm{El}$ contenido del requerimiento de pago que deba hacerse al deudor; en los casos en que la ley establezca este requerimiento.”. 
estende ainda para a realização de penhoras $^{384}$, nomeação de peritos avaliadores $^{385}$, presidência de leilões ${ }^{386}$, aprovação ou recusa de arrematações e promoção de acordos entre as partes.

Apesar de posições doutrinárias defendendo ter havido a desjudicialização da execução espanhola ${ }^{387}$, a posição não se sustenta, ao menos nas bases aqui delineadas, haja vista que a maior parte dos atos executivos ainda é praticada dentro do judiciário, quer seja a ordem de execução - dada pelo juiz - quer sejam os demais atos - praticados pelos secretários judiciais $^{388}$.

Sem prejuízo, há espaço para desjudicializações incidentais, como a possibilidade de venda do bem penhorado por empresa privada especializada, nos termos do artigo 641 da Ley de enjuiciamiento civil $^{389}$.

Trata-se de via criada em razão da pouca funcionalidade do leilão judicial até então praticado, muito prejudicado por finalidades fraudulentas almejadas pelas pessoas que atendiam a estes certames ${ }^{390}$. Pode ser solicitada pelo exequente ou até mesmo pelo executado e conduz à nomeação, feita pelo secretario judicial, de pessoas físicas ou jurídicas conhecedoras do mercado relativo aos bens penhorados e aptas a operarem nele. Este terceiro

\footnotetext{
384 CADENAS, Manuel Cachón. Apuntes de ejecución procesal civil. Barcelona: Universitat Autònoma de Barcelona, 2011, p. 41.

385 Ibidem, p. 73.

386 SICA, Heitor Vitor Mendonça. Direito processual civil espanhol. In: CRUZ E TUCCI, José Rogério (coord.). Direito processual civil europeu contemporâneo. São Paulo: Lex Editora, 2010, p. 101.

${ }^{387}$ MARTÍN, Juan F. Garnica. Reparto de funciones entre juez y secretario em la ejecución. Disponível em <http://www.cej-

mjusticia.es/cej_dode/doc_users/pdf/nueva_oficina_judicial/ejecucion_civil/REPARTO_DE_FUNCIONES.p df>. Acesso em 18 ago. 2015, p. 7.

${ }^{388}$ RIBEIRO, Flávia Pereira. A desjudicialização da execução civil. São Paulo: Saraiva, 2013, p. 114.

389 "A petición del ejecutante o del ejecutado con consentimiento del ejecutante y cuando las características del bien embargado así lo aconsejen, el Secretario judicial responsable de la ejecución podrá acordar, mediante diligencia de ordenación, que el bien lo realice persona especializada y conocedora del mercado en que se compran y venden esos bienes y en quien concurran los requisitos legalmente exigidos para operar en el mercado de que se trate.".

${ }^{390}$ GURI, Elisabet Cerrato. La ejecución privada por entidade o persona especializada. In: CADENAS, Manuel Cachón; JUNOY, Joan Picó. (coord.). La ejecución civil: problemas actuales. Barcelona: Atelier Libros Jurídicos, 2008, p. 239.
} 
designado presta uma caução e passa a dispor de prazo de seis meses, prorrogáveis por igual período, para ultimar a alienação. Caso não o faça por culpa sua, perde a caução fornecida ${ }^{391}$.

\subsubsection{Modelos públicos desjudicializados}

Os modelos públicos desjudicializados não são tão usuais em países de grande influência para o direito brasileiro. Todavia, o modelo é aplicado, principalmente, nos países nórdicos $^{392}$, como Finlândia e Suécia, fruto de uma cultura bastante distinta, em que a administração pública goza de amplos poderes para o exercício das funções estatais, sem necessidade de um constante suporte judiciário ${ }^{393}$.

Na Suécia, uma das nações adeptas do modelo executivo público desjudicializado, a execução das obrigações de pagar quantia é função atrelada à administração pública ${ }^{394}$, ou seja, cumprida por um órgão público de abrangência nacional denominado Serviço de Execução de Dívidas (kronofogdemyndigheten), cujo oficial sênior e responsável pela maior parte dos atos executivos é um oficial de execução (kronofogde $)^{395}$.

Estes oficiais de execução são funcionários públicos com formação jurídica especializada, vinculados à administração e por ela remunerados, submetidos ao mesmo regime de responsabilidade dos demais servidores públicos. São auxiliados por outros

\footnotetext{
${ }^{391}$ CADENAS, Manuel Cachón. Apuntes de ejecución procesal civil. Barcelona: Universitat Autònoma de Barcelona, 2011, p. 80.

392 REETZ DE PAIVA, Daniela. A desjudicialização dos atos executórios. Escola da magistratura do estado do Rio de Janeiro - Série aperfeiçoamento de magistrados, Curso "Fomento Mercantil - Factoring", n. 9, Rio de Janeiro, out. 2011, p. 35.

${ }^{393}$ SCHENK, Leonardo Faria. Distribuição de competências no processo executivo português reformado. Revista eletrônica de Direito Processual, Rio de Janeiro, ano 3, vol. III, jan.-jun. 2009, p. 213.

${ }^{394}$ LEBRE DE FREITAS, José. A ação executiva à luz do Código de Processo Civil de 2013. 6 ed. Coimbra: Coimbra Editora, 2014, p. 30.

${ }^{395}$ RIBEIRO, Flávia Pereira. A desjudicialização da execução civil. São Paulo: Saraiva, 2013, p. 115.
} 
servidores públicos lotados no Serviços de Execução de Dívidas, estes sem nível superior, porém treinados e educados na própria instituição ${ }^{396}$.

O oficial de execução tem à sua disposição uma série de bases de dados que lhe permitem pesquisar patrimônio penhorável do devedor, podendo contar, ainda, com um dever geral de informação que recai inclusive sobre terceiros, sob pena de sanção pecuniária compulsória ${ }^{397}$.

O Serviço de Execução de Dívidas está sujeito a controle de órgãos jurisdicionais. Todavia, é comum ser exercido um controle interno, do próprio órgão, sobre seus atos, o que não afasta a possibilidade de acesso às vias judicias, notadamente no que diz respeito ao direito material das partes exequente e executada ${ }^{398}$.

A Rússia é outro país adepto da desjudicialização administrativa. A execução é de responsabilidade de um Serviço Federal de Oficiais de Execução, vinculado ao Ministério da Justiça, em que os agentes executivos contam com amplos poderes para recuperação de créditos judiciais e extrajudiciais, sujeitos a controle judicial para a eventualidade de violações às normas legais ${ }^{399}$.

A exemplo do oficial sueco, o agente executivo russo também é remunerado pela administração pública ${ }^{400}$ e atua no processo desde o seu início, recebendo o requerimento executivo, perseguindo patrimônio, avaliando e determinando a alienação de propriedades

396 HESS, Burkhard. Different enforcement structures. In: VAN RHEE, C.H.; UZELAC, Alan (coord.). Enforcement and enforceability - tradition and reform. Antwerp, Oxford, Portland: Intersentia, 2010, p. 49.

397 LEBRE DE FREITAS, José. Os paradigmas da Acção Executiva. Disponível em <http://www.dgpj.mj.pt/sections/informacao-e-eventos/anexos/professor-doutorlebre/downloadFile/file/plf.pdf?nocache=1210676672.22>. Acesso em 05 mai. 2014.

398 HESS, Burkhard. Different enforcement structures. In: VAN RHEE, C.H.; UZELAC, Alan (coord.). Enforcement and enforceability - tradition and reform. Antwerp, Oxford, Portland: Intersentia, 2010, p. 53. ${ }^{399}$ ABOLONIN, Vadim; YARKOV, Vladimir. Enforcement in Russia: a short outline. In: VAN RHEE, C.H.; UZELAC, Alan (coord.). Enforcement and enforceability - tradition and reform. Antwerp, Oxford, Portland: Intersentia, 2010, p. 223.

${ }^{400}$ Sua remuneração é invariável, independentemente do volume de processos ou dos valores recuperados, fator considerado como desmotivador para estes profissionais (Ibidem, p. 217 e 225). 
do devedor ${ }^{401}$. Tem poderes até mesmo para impor sanções ao devedor, as quais são imediatamente executáveis pelo próprio agente ${ }^{402}$.

Sem que se possa afirmar a preponderância, os Estados Unidos também podem ser mencionados como adeptos de um modelo público desjudicializado. Isto porque, em se tratando de sistema federativo que confere soberania a cada estado, cada ente desenvolveu sua regulamentação sobre o assunto, o que gerou um emaranhado de que dificulta sobremaneira a sistematização da execução lá praticada ${ }^{403}$. Cite-se, a título de exemplo, que, via de regra, o cidadão de um determinado estado não pode ser diretamente atingido por uma decisão de outro estado antes de passar pelo crivo de sua própria Justiça ${ }^{404}$.

Ainda assim, como a maior parte dos estados-membros adotou procedimentos similares às Federal Rules of Civil Procedure $e^{405}$ - legislação inspirada no modelo inglês ${ }^{406}$ - é possível, a partir dela, a extração de alguns elementos comuns, dentre eles o tratamento dispendido à execução como matéria administrativa ${ }^{407}$, fazendo uso de agentes desta natureza para a conformação da prática ${ }^{408}$.

${ }^{401}$ Ibidem, p. 230.

${ }^{403}$ PAJIC, Natasa. Avenues for enforcement and execution of judgments in the United States. In: VAN RHEE, C.H.; UZELAC, Alan (coord.). Enforcement and enforceability - tradition and reform. Antwerp, Oxford, Portland: Intersentia, 2010, p. 237.

${ }^{404}$ ZACLIS, Lionel. Direito processual civil estadunidense. In: CRUZ E TUCCI, José Rogério (coord.). Direito processual civil americano contemporâneo. São Paulo: Lex Editora, 2010, p. 198

405 Ibidem, p. 169.

${ }^{406}$ A despeito de o ordenamento estadunidense ser de inspiração inglesa, o federalismo americano e o rápido desenvolvimento econômico e social do país conferiram formatação singular ao Direito dos Estados Unidos, divorciando parcialmente suas características das britânicas e aproximando-o dos modelos jurídicos RomanoGermânicos, com adoção da regra escrita em larga escala (GOUVEIA, Ana Carolina Miguel. Common law no sistema jurídico americano: evolução, críticas e crescimento do direito legislado. Escola da Advocacia-Geral da União Ministro Victor Nunes Leal Publicações da Escola da AGU, $1^{\circ}$ Curso de Introdução ao Direito Americano: Fundamental of US Law Course, Brasília, Ano III, n. 12, set.-out. 2011, p. 11 e 34). Sobre a execução inglesa, v. nota de rodapé no tópico sobre modelos públicos judicializados.

${ }^{407}$ COELHO, Gláucia Mara. Notas sobre a execução de decisão judicial que determina o pagamento de quantia nos EUA e na Inglaterra. Revista Magister de Direito Civil e Processual Civil, Porto Alegre, ano VIII, n 43, jul.-ago. 2011, p. 51.

${ }^{408}$ VERGUEIRO, Luiz Fabricio Thaumaturgo. Enforcement - Aspectos do cumprimento de decisões judiciais nos Estados Unidos da América. Escola da Advocacia-Geral da União Ministro Victor Nunes Leal Publicações 
Pelo procedimento, após a expedição do writ of execution pelo tribunal, é designado, em lugar dos enforcement agents privados que atuam no ordenamento britânico, um agente público administrativo, que pode ser um sheriff - oficial do condado ${ }^{409}$, formalmente inseridos na estrutura organizacional do Poder Executivo ${ }^{410}$, sendo, inclusive, eleito para o exercício da função, remunerado por honorários a cargo do executado mas antecipados pelo exequente $^{411}$ - ou um marshall - com funções semelhantes às do sheriff, responsável pelos writ federais -, que ficará encarregado da constrição e alienação de bens do devedor ${ }^{412}$ até a recuperação do crédito.

\subsubsection{Modelos privados desjudicializados}

Os modelos preponderantemente desjudicializados privados também contam com adeptos no ordenamento estrangeiro. As conformações dos procedimentos têm variações, mas, de modo geral, concentram a maior parte dos atos executivos, desde os mais triviais, como autuação e movimentação do processo, até os mais relevantes, como ordens de penhora e de alienação de bens, em agentes privados, segmentados do Poder Judiciário.

Nas próximas linhas, serão detalhados os procedimentos francês e, com maior preocupação, português, dada a maior representatividade de tais sistemas para o

da Escola da $A G U, 1^{\circ}$ Curso de Introdução ao Direito Americano: Fundamental of US Law Course, Brasília, Ano III, n. 12, set.-out. 2011, p. 254.

$409 \mathrm{O}$ condado é uma subdivisão administrativa do estado, menor que este, portanto, porém maior que uma cidade (VERGUEIRO, Luiz Fabricio Thaumaturgo. Enforcement - Aspectos do cumprimento de decisões judiciais nos Estados Unidos da América. Escola da Advocacia-Geral da União Ministro Victor Nunes Leal Publicações da Escola da AGU, $1^{\circ}$ Curso de Introdução ao Direito Americano: Fundamental of US Law Course, Brasília, Ano III, n. 12, set.-out. 2011, p. 255).

${ }^{410}$ VERGUEIRO, Luiz Fabricio Thaumaturgo. Enforcement - Aspectos do cumprimento de decisões judiciais nos Estados Unidos da América. Escola da Advocacia-Geral da União Ministro Victor Nunes Leal Publicações da Escola da $A G U, 1^{\circ}$ Curso de Introdução ao Direito Americano: Fundamental of US Law Course, Brasília, Ano III, n. 12, set.-out. 2011, p. 255

${ }^{411}$ COELHO, Gláucia Mara. Notas sobre a execução de decisão judicial que determina o pagamento de quantia nos EUA e na Inglaterra. Revista Magister de Direito Civil e Processual Civil, Porto Alegre, ano VIII, $\mathrm{n}^{\circ} 43$, jul.-ago. 2011, p. 54.

412 Ibidem, p. 52. 
ordenamento brasileiro. Todavia, cabe lembrar que estes países não são os únicos a adotarem modelos preponderantemente desjudicializados privados, sendo o caso também dos modelos praticados na Holanda, Bélgica, Escócia ${ }^{413}$, Macedônia ${ }^{414}$, dentre outros.

\subsubsection{França}

A execução de títulos judiciais e extrajudiciais, na França, é regulamentada pelo Code des procédures civiles d'exécution, que prevê duas figuras essenciais na realização do processo executivo: o huissier de justice (oficial de justiça) e o juge de l'exécution (juiz de execução).

Os huissiers, previstos nos artigos L122-1 e seguintes do Code des procédures civiles d'exécution, são profissionais liberais privados, com formação jurídica, remunerados, conforme o Décret n 96-1080, de dezembro de 1996, por honorários legalmente fixados e

413 HESS, Burkhard. Different enforcement structures. In: VAN RHEE, C.H.; UZELAC, Alan (coord.). Enforcement and enforceability - tradition and reform. Antwerp, Oxford, Portland: Intersentia, 2010, p. 4546. O autor ressalta que, nestes países, a execução é conduzida por agentes liberáis privados, sujeitos a competição entre si. Além disso, coexistem e por vezes concorrem com um sistema judicializado, conduzido por agentes públicos. Em geral, são remunerados por taxas e responsáveis por uma ampla gama de tarefas, desde a documentação até a coleta de débitos. A Holanda, específicamente, passou por reforma no ano de 2001 que provocou substanciais alterações na atuação de seus agentes executivos, tendo sido ampliada a liberdade de suas atuações, permitindo desde a livre iniciativa para o estabelecimento de escritorios de agentes executivos, até a livre fixação de preços com o credor (JONGBLOED, Anthonie. The Dutch Court Bailiffs Act eight years after its introduction. In: VAN RHEE, C.H.; UZELAC, Alan (coord.). Enforcement and enforceability - tradition and reform. Antwerp, Oxford, Portland: Intersentia, 2010, p. 181). Estas mudanças trouxeram algumas consequências que a doutrina ressalva, tais como o endurecimento no tratamento com o devedor em razão da competição pela recuperação de créditos e uma sobrecarga no custo arcado pelo devedor, frequentemente sobretaxado como forma de compensação de preços mais baixos praticados com o credor (VAN RHEE, C.H. The history of the 'hussier de justice' in the Low Countries. In: VAN RHEE, C.H.; UZELAC, Alan (coord.). Enforcement and enforceability - tradition and reform. Antwerp, Oxford, Portland: Intersentia, 2010, p. 174).

${ }^{414}$ BABUNKSI, Vladimir. Reform of the enforcement procedure in the Republic of Macedonia. In: VAN RHEE, C.H.; UZELAC, Alan (coord.). Enforcement and enforceability - tradition and reform. Antwerp, Oxford, Portland: Intersentia, 2010, p. 234. O modelo macedônico vigente decorreu de uma desjudicialização privada na execução, inspirada no modelo holandês. $\mathrm{O}$ autor registra que a alteração resultou num salto de 10 para 44 pontos percentuais no que concerne a processos finalizados com sucesso. 
por comissões recebidas das partes em função da recuperação do crédito - mediante acordo ou execução forçada ${ }^{415}$.

A despeito de serem profissionais liberais integrantes da iniciativa privada e remunerados por tarifas pagas pelas partes ${ }^{416}$, estes agentes de execução são nomeados pelo Garde des Sceaux (Ministério da Justiça) ${ }^{417}$ e exercem função pública, inclusive com poderes específicos para tanto, possuindo ampla regulamentação ${ }^{418}$.

Os huissiers de justice detêm o monopólio da execução forçada de decisões judiciais e outros títulos, bem como da apreensão de bens para conservação, expressamente previstos no artigo L122-1 do Code des procédures civiles d'exécution, dispensada até mesmo a necessidade de obtenção de fórmula executiva perante o judiciário ou tabelionato ${ }^{419}$.

O exercício de suas funções se dá, necessariamente, em um escritório cuja área de atuação corresponde à competência territorial do Tribunal de Grande Instância (Tribunal de grande instance) ao qual se acha vinculado ${ }^{420}$. O profissional pode tanto criar seu próprio escritório quanto ser contratado por um já existente ${ }^{421}$, todavia, em qualquer hipótese, será

\footnotetext{
${ }^{415}$ BATISTA SANTOS, Guilherme Luis Quaresma. Contraditório e execução. Rio de Janeiro: Lumen Juris, 2013, p. 190; REETZ DE PAIVA, Daniela. A desjudicialização dos atos executórios. Escola da magistratura do estado do Rio de Janeiro - Série aperfeiçoamento de magistrados, Curso "Fomento Mercantil - Factoring", n. 9, Rio de Janeiro, out. 2011, p. 36.

${ }^{416}$ CHARDON, Mathieu. Enforcement in France: an overview of legislation and practice. In: VAN RHEE, C.H.; UZELAC, Alan (coord.). Enforcement and enforceability - tradition and reform. Antwerp, Oxford, Portland: Intersentia, 2010, p. 153.

417 A nomeação se dá após treinamento e aprovação em processo seletivo restrito a graduados em Direito (REETZ DE PAIVA, Daniela. A desjudicialização dos atos executórios. Escola da magistratura do estado do Rio de Janeiro - Série aperfeiçoamento de magistrados, Curso "Fomento Mercantil - Factoring", n. 9, Rio de Janeiro, out. 2011, p. 35; CHARDON, Mathieu. Enforcement in France: an overview of legislation and practice. In: VAN RHEE, C.H.; UZELAC, Alan (coord.). Enforcement and enforceability - tradition and reform. Antwerp, Oxford, Portland: Intersentia, 2010, p. 154)

${ }^{418}$ HENDERSON, Keith; SHAH, Angana; ELENA, Sandra; AUTHEMAN, Violaine. Regional Best Practices: enforcement of court judgments, lessons learned from Latin America. Washington: IFES, 2004. Disponível em < http://pdf.usaid.gov/pdf_docs/PBAAB593.pdf>. Acesso em 30 ago. 2015, p. 23.

${ }^{419}$ REETZ DE PAIVA, Daniela. A desjudicialização dos atos executórios. Escola da magistratura do estado do Rio de Janeiro - Série aperfeiçoamento de magistrados, Curso "Fomento Mercantil - Factoring", n. 9, Rio de Janeiro, out. 2011, p. 35.

${ }^{420}$ GRECO, Leonardo. O processo de execução: volume I. Rio de Janeiro: Renovar, 1999, p. 86.

${ }^{421}$ RIBEIRO, Flávia Pereira. A desjudicialização da execução civil. São Paulo: Saraiva, 2013, p. 105.
} 
pessoalmente responsável pelos atos que praticar, não lhe sendo facultada a responsabilidade limitada da pessoa jurídica à qual se acha vinculado ${ }^{422}$.

Já o juge de l'exécution é profissional especializado integrante do correlato Tribunal de grande instance, e tem um poder geral de controle formal sobre o processo executivo, cabendo a ele apreciar e decidir, em síntese, sobre eventuais defeitos do título executório, medidas desnecessárias ou abusivas e fixar responsabilidades pelos excessos ${ }^{423}$, tudo nos termos dos artigos L213-6 do Code de l'organisation judiciaire (Código de Organização Judiciária) e L121-1 e L121-2 do Code des procédures civiles d'exécution.

Pelo procedimento previsto nos artigos L211-1 e seguintes do Code des procédures civiles d'exécution, nas hipóteses em que a penhora recai só sobre bens móveis ou quantias em dinheiro, os huissiers podem realizar a execução toda, desde a notificação inicial, passando pela penhora e alienação pública, até a satisfação, sem qualquer acionamento do Judiciário, exceto na eventualidade de oposição de embargos ${ }^{424}$. Têm liberdade inclusive para, dentre outras variáveis, proporem plano de pagamento, celebrarem acordos, escolherem o método executivo mais adequado e requererem reforço policial ${ }^{425}$.

Já quando a penhora recai sobre bens imóveis, há um procedimento especial previsto nos artigos 311-1 e seguintes do Code des procédures civiles d'exécution em que os huissiers atuam conjuntamente com o juge de l'exécution competente para o feito, este responsável pela penhora e venda dos bens e aquele pelo cumprimento das ordens do magistrado ${ }^{426}$.

Estes profissionais, a despeito de usufruírem de ampla liberdade para o exercício de suas funções, estão submetidos à vigilância disciplinar da correlata associação

${ }^{422}$ KENNETT, Wendy. The enforcement of judgements in Europe. Oxford: Oxford University Press, 2000 , p. 78.

${ }^{423}$ CHARDON, Mathieu. Training judicial officers in France. In: VAN RHEE, C.H.; UZELAC, Alan (coord.). Enforcement and enforceability - tradition and reform. Antwerp, Oxford, Portland: Intersentia, 2010, p. 155.

${ }^{424}$ RIBEIRO, Flávia Pereira. A desjudicialização da execução civil. São Paulo: Saraiva, 2013, p. 103.

425 Ibidem, p. 104.

${ }^{426}$ BATISTA SANTOS, Guilherme Luis Quaresma. Contraditório e execução. Rio de Janeiro: Lumen Juris, 2013, p. 190. 
profissional $^{427}$, além do Ministério Público, na condição de fiscal dos processos executivos, nos termos dos artigos 121-5 e 121-6 do Code des procédures civiles d'exécution.

\subsubsection{Portugal}

Até o ano de 2003, Portugal tinha um sistema executivo muito similar ao brasileiro atual, com concentração das atividades executivas no Judiciário, mais especificamente nas mãos do juiz, que dirigia e promovia as diligências necessárias ao deslinde processual $^{428}$.

Contudo, um cenário de excessivo congestionamento e morosidade de processos, muito influenciado pelos processos de cobrança de dívidas, conduzindo à constatação de que uma série de demandas de baixa complexidade tomavam muito tempo e recursos de tribunais portugueses $^{429}$, aliados à citada tendência de harmonização de sistemas jurídicos na União Europeia $^{430}$, impulsionaram um movimento político de redução da presença do Estado na área judicial por meio da transferência de funções à iniciativa privada ${ }^{431}$, tendência que, digase, já não era inédita no histórico de reformas portuguesas ${ }^{432}$, em que pese, até então, não ter sido estendida à execução.

\footnotetext{
${ }^{427}$ REETZ DE PAIVA, Daniela. A desjudicialização dos atos executórios. Escola da magistratura do estado do Rio de Janeiro - Série aperfeiçoamento de magistrados, Curso "Fomento Mercantil - Factoring", n. 9, Rio de Janeiro, out. 2011, p. 36.

${ }^{428}$ LEBRE DE FREITAS, José. A ação executiva à luz do Código de Processo Civil de 2013. 6 ed. Coimbra: Coimbra Editora, 2014, p. 29.

${ }^{429}$ SANTOS, Boaventura de Sousa. A justiça em Portugal: diagnóstico e terapêuticas. Manifesto, Lisboa, n. 7 , p. $76-87$, mar. 2005 , p. $83-84$.

${ }^{430}$ Ideia atrelada à máxima da necessidade de circulação de prestação de serviços, que passou a ser vista, também, como solução ao Judiciário (ALEMÃO, Ivan. A reforma da execução em Portugal. Disponível em $<$ http://jus.com.br/revista/texto/10000/reforma-da-execucao-em-portugal $>$. Acesso em 09 out. 2012).

${ }^{431}$ PAIVA, Eduardo; CABRITA, Helena. O processo executivo e o agente de execução. 3 ed. Coimbra: Coimbra Editora, 2013, p. 14.

${ }^{432}$ TEIXEIRA DE SOUZA, Miguel. Um novo processo civil português: à la recherche du temps perdu? Revista de Processo, v. 161, p. 203, jul. 2008, p. 5.
} 
Um primeiro passo neste sentido foi dado com a edição do Decreto-Lei n ${ }^{\circ} 38 / 2003^{433}$, que, tomando inspiração francesa ${ }^{434}$, promoveu uma desjudicialização parcial, cuidando da transferência de tarefas executivas dos cartórios judiciais e do juiz, que não importassem em exercício estrito do poder jurisdicional - tais como a decisão sobre quem citar, o quê, como e quanto penhorar e modalidade de venda do bem -, para um agente de execução ${ }^{435}$, que, portanto, a um só movimento, assumiu responsabilidades dos funcionários judiciais e do juiz $^{436}$. Com este último foi mantida a maior parte de seu poder jurisdicional ${ }^{437}$, notadamente para exercer um poder geral de controle sobre o processo $^{438}$.

Porém, esta primeira alteração acabou por entrar em vigor "sem que o terreno estivesse inteiramente preparado para a receber" ${ }^{\prime 39}$, despontando problemas como a falta de meios humanos e materiais, bem como de qualificação dos agentes executivos de então ${ }^{440}$. No intento de reparar estes e outros problemas, cinco anos depois foi editado o Decreto-Lei

\footnotetext{
${ }^{433}$ A reforma não se reduziu a um único decreto, tendo sido complementada pelos Decretos-Lei no 199/2003 que alterou o Decreto 38/2003 -, 200/2003 - que aprovou modelo de requerimento executivo -, 201/2003 e 202/2003 - que regulamentaram aspectos eletrônicos da execução - e 204/2003, que estabeleceu regime especial de custas judiciais nas execuções que tramitassem com o agente executivo (MENDES, Armindo Ribeiro. Execução e registro. Themis - Revista da Faculdade de Direito da UNL, Coimbra, ano V, n 09, mar. 2004, p. 207).

${ }^{434}$ BATISTA SANTOS, Guilherme Luis Quaresma. Contraditório e execução. Rio de Janeiro: Lumen Juris, 2013, p. 191; MENDES, Armindo Ribeiro. Forças e fraquezas do modelo português de aç̧ão executiva no limiar do século XXI - que modelo para o futuro? Supremo Tribunal de Justiça, 27 de maio de 2010, Disponível em 〈http://www.stj.pt/ficheiros/coloquios/coloquiprocessocivil_ribeiromendes.pdf > . Acesso em 05 mai. 2014. ${ }^{435}$ GERALDES, António Santos Abrantes. O juiz e a execução. Themis - Revista da Faculdade de Direito da UNL, Coimbra, ano V, n ${ }^{\circ}$ 09, mar. 2004, p. 28.

${ }^{436}$ PIMENTA, Paulo. Reflexões sobre a nova acção executiva. Sub Judice: justiça e sociedade, Coimbra, ${ }^{\circ}$ 29, out./dez. 2004, p. 84.

${ }^{437}$ FIALHO, António José. Da teoria à prática - Algumas dificuldades na aplicação do novo regime da acção executiva. Sub Judice: justiça e sociedade, Coimbra, nº 29, out./dez. 2004, p. 69.

${ }^{438}$ REGO, Carlos Lopes do. As funções e o estatuto processual do agente de execução e seu reflexo no papel dos demais intervenientes no processo executivo. Themis - Revista da Faculdade de Direito da UNL, Coimbra, ano V, n ${ }^{\circ} 09$, mar. 2004, p.43.

${ }^{439}$ LEBRE DE FREITAS, José. O primeiro ano de uma reforma executiva adiada. Sub Judice: justiça e sociedade, Coimbra, $\mathrm{n}^{\circ} 29$, out./dez. 2004, p. 7.

${ }^{440}$ TEIXEIRA, Paulo Duarte. Apresentação. Sub Judice: justiça e sociedade, Coimbra, no 29, out./dez. 2004, p.5; CAMPOS, Isabel Menéres. As questões não resolvidas da reforma da acção executiva. Sub Judice: justiça e sociedade, Coimbra, $\mathrm{n}^{\circ} 29$, out./dez. 2004, p. 59.
} 
$n^{\circ} 226 / 2008$, que entrou em vigor em março de 2009 e ampliou a desjudicialização que já tinha sido implantada em 2003.

Em atenção às deficiências da reforma anterior, nesta foram adotadas medidas como a informatização do processo, criação de uma lista pública de execuções infrutíferas pela inexistência de bens do executado, restrição da atuação do juiz, acionado apenas para solução de eventuais conflitos e criação de uma Comissão para controle externo da eficácia das execuções.

Contudo, a principal mudança veio com o reforço do papel do agente de execução, com o aumento dos poderes, outorgando-lhe inclusive atos de cunho jurisdicional ${ }^{441}-$ com consequente redução na atuação dos juízes ${ }^{442}$-, contingente e melhora na remuneração, além de autorizar sua livre destituição pelo exequente, tornando essa relação em algo muito próximo a um mandato de direito privado, a despeito do exercício de função pública ${ }^{443}$. Esta dicotomia, inclusive, gerou uma divergência quanto à natureza jurídica de tais profissionais, adiante explicada.

Houve, ainda, um favorecimento à tutela do interesse do exequente, com medidas como a publicidade da situação patrimonial do executado, a supressão do direito do executado de nomeação de bens à penhora, iniciando-se a expropriação pelo bem mais acessível e a presunção de titularidade de todos os bens em posse do executado ${ }^{444}$.

\footnotetext{
${ }^{441}$ SERRA, Miguel Dinis Pestana. Breve análise crítica de algumas das alterações ao regime da acção executiva portuguesa. Revista Jus Navigandi, Teresina, ano 14, n. 2369, 26 dez. 2009. Disponível em: <http://jus.com.br/artigos/14066>. Acesso em: 28 ago. 2015.

442 CATERINA, Rafaela Marjorie de Oliveira. Considerações sobre o processo executivo no direito comparado: a reforma executiva em Portugal e o título executivo europeu. Disponível em <http://ww.diritto.it/docs/33193-considera-es-sobre-o-processo-executivo-no-direito-comparado-areformaexecutiva-em-portugal-e-o-t-tulo-executivo-europeu>. Acesso em 05 mai. 2014.

${ }^{443}$ BATISTA SANTOS, Guilherme Luis Quaresma. Contraditório e execução. Rio de Janeiro: Lumen Juris, 2013, p. 198. RIBEIRO, Flávia Pereira. A desjudicialização da execução civil. São Paulo: Saraiva, 2013, p.128. ${ }^{444}$ RIBEIRO, Flávia Pereira. A desjudicialização da execução civil. São Paulo: Saraiva, 2013, p. 129.
} 
Sem prejuízo, é consensual a afirmação de que, com estas alterações, Portugal abandonou definitivamente o modelo de matriz pública judicializada para incorporar um sistema de acentuado caráter privado, similar ao da execução francesa.

Em $1^{\circ}$ de setembro de 2013 entrou em vigor a Lei n. ${ }^{\circ} 41 / 2013$, o novo Código de Processo Civil português (NCPCp). A despeito de algumas mudanças no que concerne à execução, a legislação manteve a essência da reforma recém-implantada ${ }^{445}$.

Como os problemas enfrentados e o modelo processual portugueses eram bastante similares aos brasileiros atuais e a saída buscada foi, justamente, a desjudicialização aqui tratada, convém uma análise mais dedicada do modelo lá implantado.

\subsection{Os órgãos atuantes na execução}

Na execução portuguesa funcionam, simultânea e harmonicamente, três órgãos: os agentes executivos, os juízes de execução e a Comissão para o Acompanhamento dos Auxiliares da Justiça, a seguir discriminados.

\subsection{Agente de execução}

Já a partir do Decreto-Lei $n^{\circ} 38 / 2003$, os solicitadores, profissionais liberais com formação jurídica, com estatuto e fiscalização atrelados a uma Câmara de Solicitadores ${ }^{446}$ e que até então só tinham atribuições jurídicas menores, passaram a desempenhar o papel de agentes de execução, realizando todas as diligências desta espécie de processo, como

445 BATISTA SANTOS, Guilherme Luis Quaresma. Contraditório e execução. Rio de Janeiro: Lumen Juris, 2013, p. 197.

${ }^{446}$ GOMES, Manuel Tomé. Balanço da reforma da acção executiva. Sub Judice: justiça e sociedade, Coimbra, n 29 , out./dez. 2004, p. 31. 
citações, notificações, publicações, penhoras, vendas e pagamentos ${ }^{447}$, liberando não só os juízes como também as secretarias judiciais ${ }^{448}$

A transferência, contudo, não foi bem-sucedida, principalmente no que concerne à atribuição das funções aos solicitadores, dadas as escassas formação técnica e experiência destes profissionais com a execução ${ }^{449}$. Diante desse quadro, a partir do Decreto-Lei $\mathrm{n}^{\circ}$ 226/2008 passou a ser possível também aos advogados atuarem como agentes de execução, desde que devidamente habilitados ${ }^{450}$.

A atividade dos agentes de execução, hoje, está regulamentada pela Portaria $\mathrm{n}^{\circ}$ 282/2013 do Ministério da Justiça e pelo Novo Código de Processo Civil português. O artigo $719^{\circ}$ deste último diploma prevê, expressamente, atribuição destes profissionais para efetuarem todas as diligências de execução, incluindo as citações, notificações e publicações consultas de bases de dados, penhoras e seus registros, liquidações e pagamentos.

Estes agentes são escolhidos pelo exequente a partir de uma lista disponibilizada pela Câmara de Solicitadores ${ }^{451}$ e acionados a partir de um requerimento eletrônico, sendo livres tanto a anuência do agente ${ }^{452}$ quanto a sua posterior destituição pelo exequente ${ }^{453}$, havendo, nesta última, necessidade de fundamentação, porém sem que essas razões sejam apreciadas

${ }^{447}$ RIBEIRO, Flávia Pereira. A desjudicialização da execução civil. São Paulo: Saraiva, 2013, p. 130.

${ }^{448}$ LEBRE DE FREITAS, José. Penhora e oposição do executado. Themis - Revista da Faculdade de Direito da UNL, Coimbra, ano V, nº 09, mar. 2004, p. 11.

449 ALEMÃO, Ivan. A reforma da execução em Portugal. Disponível em <http://jus.com.br/revista/texto/10000/reforma-da-execucao-em-portugal>. Acesso em 09 out. 2012.

${ }^{450}$ BATISTA SANTOS, Guilherme Luis Quaresma. Contraditório e execução. Rio de Janeiro: Lumen Juris, 2013, p. 194-196.

${ }^{451}$ Trata-se de associação de Direito Público representativa dos solicitadores portugueses (Disponível em <http://solicitador.net/apresentacao/camara-dos-solicitadores/missao/>. Acesso em 22 ago. 2015).

${ }^{452} \mathrm{O}$ artigo 720, item 8 do NCPCp prevê que "A designação do agente de execução fica sem efeito se ele declarar que não a aceita por meios eletrónicos, nos termos a definir por portaria do membro do Governo responsável pela área da justiça. ".

${ }^{453}$ Conforme artigo $720^{\circ}$, item 4 do NCPCp, "sem prejuízo da sua destituição pelo órgão com competência disciplinar, o agente de execução pode ser substituído pelo exequente, devendo este expor o motivo da substituição; a destituição ou substituição produzem efeitos na data da comunicação ao agente de execução, efetuada nos termos definidos por portaria do membro do Governo responsável pela área da justiça. ". 
por qualquer pessoa ${ }^{454}$. Além disso, não têm subordinação hierárquica em relação ao juiz ${ }^{455}$ e a remuneração consiste em honorários pagos pelas partes pelos serviços prestados, bem como no reembolso das despesas realizadas e comprovadas ${ }^{456}$. Todas estas características acentuam seu caráter privado.

De outra sorte, a indicar aspectos públicos de sua atividade, os agentes de execução, detêm status de auxiliares da justiça ${ }^{457}$ e devem respeito ao Estatuto dos Solicitadores, podendo, em caso de descumprimento, sofrer sanções disciplinares tanto da Comissão para o Acompanhamento dos Auxiliares de Justiça quanto do respectivo órgão de classe ${ }^{458}$.

Em função desta mescla, não há consenso na doutrina e jurisprudência portuguesas acerca da natureza jurídica do agente executivo. Há quem entenda que é puramente privada, em função das primeiras características, e há quem entenda que é híbrida, em razão das segundas.

Essa divergência repercute, principalmente, no campo da responsabilidade pelos ilícitos praticados pelos agentes de execução, ora alocada no campo da responsabilidade civil, ora no da responsabilidade administrativa, com o Estado respondendo pela ação de seus agentes ${ }^{459}$.

${ }^{454}$ LEBRE DE FREITAS, José. A ação executiva à luz do Código de Processo Civil de 2013. 6 ed. Coimbra: Coimbra Editora, 2014, p. 33.

${ }^{455}$ BRESOLIN, Humberto Bara. Execução extrajudicial imobiliária: aspectos práticos. São Paulo: Atlas, 2013 , p. 56.

${ }_{456}$ Assim na literalidade do artigo $43^{\circ}$ da Portaria n $282 / 2013$ do Ministério da Justiça.

${ }^{457}$ LEBRE DE FREITAS, José. A ação executiva à luz do Código de Processo Civil de 2013. 6 ed. Coimbra: Coimbra Editora, 2014, p. 34.

${ }^{458}$ v. item abaixo sobre a Comissão para o Acompanhamento dos Auxiliares da Justiça (CAAJ).

${ }^{459}$ José Lebre de Freitas desenvolve a questão com maior minúcia, pontuando os entendimentos emanados das cortes de segunda e terceira instâncias, bem como da doutrina local, para um e para outro entendimento $(A$ ação executiva à luz do Código de Processo Civil de 2013. 6 ed. Coimbra: Coimbra Editora, 2014, p. 33-35). $\mathrm{O}$ autor, em específico, é adepto da teoria híbrida, por considerar que a caracterização do agente executivo como puramente privado implica na quebra de seu dever de imparcialidade. 
Nos locais onde não há agente executivo ou não lhe for possível a nomeação, o exequente pode requerer que as diligências sejam realizadas por oficial de justiça, o qual é nomeado conforme as regras de distribuição ${ }^{460}$.

Atuam com ampla liberdade, tanto na condução e prática de atos executivos, tais como penhora e expropriação de bens do executado, atuando como depositário, requisitando força policial, dentre outras providências, quanto exercendo cognição - ainda que, em geral, superficial -, podendo, por exemplo, deferir requerimento de herdeiro para levantamento de penhora - artigo $827^{\circ}$, item 2 do Código de Processo Civil português - e reduzir eventual penhora excessiva - artigo $861^{\circ}$-A do Código de Processo Civil português ${ }^{461}$.

\subsection{Juiz de execução}

O juiz de execução português se assemelha muito ao juiz de execução francês. Foi introduzido naquele ordenamento pelo Decreto-Lei $n^{\circ} 38 / 2003^{462}$, tendo sofrido sua última alteração pelo Decreto-Lei no 226/2008, mantida, em essência, no artigo $723^{\circ}$ do NCPCp.

Neste cenário, foi reduzida a atuação do juiz executivo para hipóteses em que houver efetivo conflito ou questão relevante ${ }^{463}$, deixando de promover, via de regra, atos de direção

\footnotetext{
${ }^{460} \mathrm{v}$. item abaixo sobre o procedimento executivo português.

${ }^{461}$ GARSON, Samy. A desjudicialização da execução hipotecária como meio alternativo de recuperação de créditos. 156 f. Dissertação (Mestrado em Ciências Jurídico-Processuais)-Faculdade de Direito, Universidade de Coimbra, Coimbra, 2006, p. 35.

462 MENDES, Armindo Ribeiro. Forças e fraquezas do modelo português de aç̧ão executiva no limiar do século XXI - que modelo para o futuro? Supremo Tribunal de Justiça, 27 de maio de 2010, Disponível em <http://www.stj.pt/ficheiros/coloquios/coloquiprocessocivil_ribeiromendes.pdf>. Acesso em 05 mai. 2014.

${ }^{463}$ BATISTA SANTOS, Guilherme Luis Quaresma. Contraditório e execução. Rio de Janeiro: Lumen Juris, 2013, p. 198.
} 
do processo ${ }^{464}$, tais como determinação de penhora ou venda ou mesmo a extinção do feito executivo, atos que anteriormente lhe competiam ${ }^{465}$.

Exerce, hoje, em suma, poderes de tutela e controle do processo $^{466}$ : no exercício da tutela, lhe é possibilitada a intervenção para a solução de eventuais litígios decorrentes da ação executiva ${ }^{467}$; no exercício do controle, atua proferindo eventual despacho liminar, decidindo eventuais questões suscitadas pelas partes, terceiros intervenientes ou pelo agente de execução ${ }^{468}$, protegendo direitos fundamentais ${ }^{469}$, assegurando a realização da execução ${ }^{470} \mathrm{e}$, principalmente, julgando, sem possibilidade de recurso, reclamações de atos e impugnações de decisões do agente de execução ${ }^{471}$.

A provocação injustificada do juiz para o exercício de seu poder de controle é passível de multa destinada ao requerente ${ }^{472}$, extensível inclusive ao agente executivo, se for o caso.

\footnotetext{
${ }^{464}$ Compreendido o poder de direção como a possibilidade de praticar atos que dão impulso à execução (GOUVEIA, Maria França. Poder geral de controlo. Sub Judice: justiça e sociedade, Coimbra, n 29 , out./dez. 2004, p. 21).

${ }^{465}$ LEBRE DE FREITAS, José. A ação executiva à luz do Código de Processo Civil de 2013. 6 ed. Coimbra: Coimbra Editora, 2014, p. 31.

${ }^{466}$ Assim sintetizado por José Lebre de Freitas, em interpretação da exposição de motivos do Decreto-Lei ${ }^{\circ}$ 226/2008 (Refoma da acção executiva - Parecer OA, 28 de março de 2008, Disponível em <http://www.inverbis.pt/2007-2011/advogados/reforma-accao-executiva-parecer-oa.html >. Acesso em 05 mai. 2014), posteriormente revisto e atualizado pelo autor com as alterações do Novo Código português ( $A$ ação executiva à luz do Código de Processo Civil de 2013. 6 ed. Coimbra: Coimbra Editora, 2014, p.30).

${ }^{467}$ A exemplo do artigo 723, item 1, alínea 'b' do NCPCp, "sem prejuízo de outras intervenções que a lei especificamente lhe atribui, compete ao juiz: [...] b) Julgar a oposição à execução e à penhora, bem como verificar e graduar os créditos, no prazo máximo de três meses contados da oposição ou reclamação.".

${ }^{468}$ As duas hipóteses textualmente previstas, respectivamente, nas alíneas 'a' e 'd' do artigo 723, item 1 do CNPCp.

${ }^{469}$ Como nas restrições à penhora estabelecidas no artigo 738 do NCPCp, notadamente a hipótese do item 6 , que prevê que "ponderados o montante e a natureza do crédito exequendo, bem como as necessidades do executado e do seu agregado familiar, pode o juiz, excecionalmente e a requerimento do executado, reduzir, por período que considere razoável, a parte penhorável dos rendimentos e mesmo, por período não superior a um ano, isentá -los de penhora. ".

${ }^{470}$ Como quando promove um pequeno incidente de cognição processual para divisão de imóvel cujo valor integral exceda o demasiadamente o valor do débito, previsão constante do artigo 759 do NCPCp.

${ }^{471}$ Hipótese textualmente prevista na alínea 'c' do artigo 723 , item 1 do NCPCp. O juiz, porém, não tem poder para destituir o agente executivo (LEBRE DE FREITAS, José. A ação executiva à luz do Código de Processo Civil de 2013. 6 ed. Coimbra: Coimbra Editora, 2014, p.32).

${ }^{472}$ Prevista no artigo $723^{\circ}$, item 2 do NCPCp.
} 
Em que pese ter previsão específica na legislação, a dificuldade de estruturação do Judiciário português fez com que poucos juízos de execução fossem criados ${ }^{473}$, de modo que, hoje, as funções previstas para este profissional são realizadas por juízes de competência genérica. $^{474}$

\subsection{Comissão para o Acompanhamento dos Auxiliares da Justiça (CAAJ)}

Diante de críticas acerca da ausência de mecanismos eficazes de controle dos solicitadores de execução quando passaram a exercer a função de agentes executivos ${ }^{475}$, o Decreto-Lei no 226/2008, regulamentado pelo Decreto-Lei no 169/2009, criou a Comissão para Eficácia das Execuções (CPEE). Tratava-se de comissão independente, encarregada de formar e disciplinar os agentes de execução, tendo poderes para até mesmo excluir determinado agente de conduta inadequada ${ }^{476}$.

Com a edição da Lei $n^{0} 77 / 2013$, esta comissão foi extinta ${ }^{477}$ e suas atividades foram absorvidas pela Comissão para o Acompanhamento dos Auxiliares da Justiça (CAAJ), entidade administrativa independente, dotada de personalidade jurídica, autonomias administrativa e financeira próprias.

Esta nova Comissão tem, essencialmente, as mesmas funções da extinta: cuida de supervisionar, regulamentar, apreciar reclamações, instruir e aplicar medidas disciplinares e, eventualmente, destituir auxiliares de justiça - categoria de profissionais que contempla o agente executivo.

${ }^{473}$ LEBRE DE FREITAS, José. Penhora e oposição do executado. Themis - Revista da Faculdade de Direito da UNL, Coimbra, ano V, nº 09, mar. 2004, p. 11.

${ }^{474}$ RIBEIRO, Flávia Pereira. A desjudicialização da execução civil. São Paulo: Saraiva, 2013, p. 136.

475 CAMPOS, Isabel Menéres. As questões não resolvidas da reforma da acção executiva. Sub Judice: justiça e sociedade, Coimbra, $\mathrm{n}^{\circ}$ 29, out./dez. 2004, p. 60.

476 RIBEIRO, Flávia Pereira. A desjudicialização da execução civil. São Paulo: Saraiva, 2013, p. 136.

${ }^{477}$ Lei no 77/2013, artigo 36º 3: "É extinta a Comissão para a Eficácia das Execuções, permanecendo esta em funções até à data de tomada de posse dos membros do órgão de gestão da CAAJ". 
Exerce estas funções, basicamente, por meio de duas subcomissões: a Comissão de Fiscalização dos Auxiliares da Justiça - composta por pessoas de "reconhecida idoneidade, independência e experiência em matéria de fiscalização de entidades públicas" e que tem por competência planejar, propor e executar atividades fiscalizatórias dos agentes executivos, como a realização de auditorias financeiras e identificação de indícios de infrações destes profissionais ${ }^{478}$ - e a Comissão de Disciplina dos Auxiliares de Justiça constituída por pessoas "com reconhecida idoneidade, independência e experiência em matéria disciplinar ou contraordenacional", atua em equipes de três colaboradores, devendo um deles ter experiência como auxiliar de justiça na área da pessoa processada, sendo competente para instaurar, instruir e julgar processos disciplinares contra auxiliares de justiça, inclusive aplicando-lhes as respectivas sanções ${ }^{479}$.

Da simples exposição de suas funções, pode-se concluir que a Comissão para o Acompanhamento dos Auxiliares da Justiça não atua propriamente no processo executivo, mas presta serviço auxiliar, essencial para a segurança jurídica de um modelo executivo que conta com um agente executivo fora do Poder Judiciário.

\subsection{O procedimento}

O Novo Código de Processo Civil português estabeleceu dois ritos procedimentais para a execução por quantia: ordinário, regulamentado nos artigos $724^{\circ}$ e seguintes do NCPCp, e sumário, regulamentado nos artigos $855^{\circ}$ e seguintes do NCPCp. Este último, utilizado em situações excepcionais, aplica-se, em regra, nos termos dos artigos $550^{\circ}$ e $626^{\circ}$ do NCPCp, nas execuções de obrigações certas, líquidas e exigíveis fundadas em decisão arbitral, requerimento de injunção com fórmula executória, títulos extrajudiciais de baixo

\footnotetext{
${ }^{478}$ Síntese dos artigos $25^{\circ}$ e $26^{\circ}$ da Lei no $77 / 2013$.

${ }^{479}$ Síntese dos artigos $27^{\circ}$ e $28^{\circ}$ da Lei n ${ }^{\circ} 77 / 2013$.
} 
valor $^{480}$ e de obrigações pecuniárias garantidas por penhor ou hipoteca e decisões judiciais que não devam ser executadas nos próprios autos do processo de conhecimento.

As principais diferenças entre um e outro rito são, no sumário, a dispensa de despacho liminar, com recebimento e processamento do requerimento executivo inicial diretamente pelo agente executivo, e a realização da penhora antes da citação do executado ${ }^{481}$.

\subsection{Rito ordinário}

O processo de execução por quantia certa pelo rito ordinário, nos termos do artigo $724^{\circ}$ do Novo Código de Processo Civil português, é iniciado com o requerimento executivo, documento direcionado ao Tribunal, que pode ser apresentado ou por meio de um advogado, pela via eletrônica, ou por meio do próprio exequente, em via impressa.

Trata-se de um documento padrão, muito similar a uma petição inicial, em que são indicados, em essência, os elementos elencados no artigo $724^{\circ}$ do NCPCp, tais como as partes, domicílio do advogado, causa de pedir - quando não constar do título -, pedido, valores da causa e da obrigação, eventual pedido de dispensa de citação prévia do executado, quando necessário para manutenção de garantia patrimonial do crédito, informações úteis à persecução do patrimônio do executado, tais como a localização de bens do devedor passíveis de penhora, dentre outras. Além disso, deve ser instruído com cópia do título executivo e documentos comprobatórios dos bens eventualmente indicados a penhora.

\footnotetext{
$480 \mathrm{O}$ valor utilizado como referência é o dobro da alçada no tribunal de primeira instância, sendo possível a utilização do rito sumário quando o valor da obrigação não o exceder. Esse valor de alçada do tribunal de primeira instância, para efeitos cíveis era, em setembro de 2015, de 5.000 euros, fixado no artigo 44, item 1 da Lei n. ${ }^{\circ}$ 62/2013, de 26 de Agosto (lei de organização do sistema judiciário português).

${ }^{481}$ LEBRE DE FREITAS, José. A ação executiva à luz do Código de Processo Civil de 2013. 6 ed. Coimbra: Coimbra Editora, 2014, p. 173.
} 
É já no requerimento executivo inicial que o exequente indica qual o agente de execução escolhido ou, alternativamente, a opção por oficial de justiça ${ }^{482}$; em se tratando da primeira, já deve demonstrar o recolhimento das quantias devidas ao agente executivo a título de honorários e despesas, salvo quando dispensado pelas normas de assistência judiciária.

Esse requerimento é encaminhado para a secretaria do Tribunal que, nos termos do artigo $725^{\circ}$ do NCPCp, pode recusar o seu processamento quando verificar ausência de algum dos elementos do requerimento padrão supracitado. O não recebimento é recorrível ao juiz de execução, somente.

Recebido o requerimento, ele é distribuído e autuado, sendo notificado o agente executivo de sua designação, sendo-lhe facultada a livre recusa da nomeação, nos termos do artigo $720^{\circ}$, item 1 do NCPCp. Em seguida, é encaminhado ao juiz para despacho liminar, que pode ser de aperfeiçoamento - correção de vício sanáveis -, indeferimento - quando os vícios forem insanáveis ou não corrigidos pela parte ${ }^{483}$-, ou de citação - caso não haja irregularidades pendentes ${ }^{484}$.

O despacho citatório, nos termos do artigo $726^{\circ}$, item 6 do NCPCp, é para que o executado pague ou, querendo, se oponha à execução. Essa citação é realizada pelo agente executivo $^{485}$ e pode ser dispensada a pedido do exequente quando houver fundado receio de perda de garantia patrimonial. Neste último caso, a citação se dará somente após a penhora,

482 A execução por oficial de justiça é excepcional e encontra arrimo no artigo $722^{\circ}$ do Novo Código de Processo Civil português. Ele assume a prática das diligências executivas, tal como um agente de execução, nas execuções em que o Estado ou o Ministério Público figurarem como exequentes; quando não houver agentes de execução inscritos no local onde for necessária a prática de atos executivos; e em execuções de baixo valor, se assim optar o exequente pessoa física e o crédito não for decorrente de atividade industrial ou comercial.

${ }^{483}$ Dão ensejo ao indeferimento, nos termos do artigo $726^{\circ}$, itens 2 e 4 do NCPCp a ausência de pressupostos processuais; a manifesta a falta ou insuficiência do título; a ocorrência de exceções dilatórias, não supríveis, de conhecimento de ofício; quando execução fundada em título negocial seja manifesta a inexistência de fatos constitutivos ou a existência de fatos impeditivos ou extintivos da obrigação exequenda; quando execução baseada em decisão arbitral, o litígio não pudesse ser cometido à decisão por árbitros, quer por estar submetido, por lei especial, exclusivamente, a tribunal judicial ou a arbitragem necessária, quer pelo direito controvertido não ter caráter patrimonial e não poder ser objeto de transação.

${ }^{484}$ LEBRE DE FREITAS, José. A ação executiva à luz do Código de Processo Civil de 2013. 6 ed. Coimbra: Coimbra Editora, 2014, p. 186.

${ }^{485}$ Nos termos do artigo $726^{\circ}$, item 8 do NCPCp. 
sobre ela cabendo a oposição, nos termos dos $\operatorname{artigos} 856^{\circ}$ e seguintes do NCPCp, procedimento previsto para o rito sumário.

Se o executado for citado posteriormente à penhora, o artigo $856^{\circ}$ do NCPCp prevê prazo de 20 dias, a contar da citação, para apresentar oposição. Neste caso, as oposições à execução e à penhora serão apresentadas conjuntamente e a suspensão da execução é automática, sem prejuízo de reforço ou substituição da penhora. Aqui, havendo procedência da oposição, a execução é extinta e o exequente responde pelos danos causados mais multa de $10 \%$ sobre a parte da execução que tiver sido objeto da oposição.

Já se a citação se der previamente à penhora, o artigo $728^{\circ}$ do NCPCp prevê prazo de 20 dias, a contar da citação, para apresentar oposição à execução. Após, quando efetivada a penhora, são garantidos ao executado novos 20 dias para apresentar oposição à penhora. Nestes casos a execução só será suspensa se for prestada caução ou se, excepcionalmente, o juiz identificar sérios indícios de irregularidade ${ }^{486}$.

As oposições são sempre endereçadas ao Tribunal (juiz de execução) e devem ser apresentadas, em regra, eletronicamente, em apenso ao processo executivo principal ${ }^{487}$.

Seus fundamentos são variáveis, a depender se o título executivo é sentença judicial, sentença arbitral ou outros tipos de título, todos previstos nos artigos $729^{\circ}$ a $731^{\circ}$ do NCPCp. De modo geral, pode-se dizer que está prevista a possibilidade de o executado atacar o título executivo- sua existência, validade, e exequibilidade -, a certeza, exigibilidade e liquidez da obrigação, questões de ordem pública referentes ao processo de execução e quaisquer fatos supervenientes ao processo de conhecimento que sejam extintivos ou modificativos da obrigação, exceção feita aos títulos não decorrentes de sentença, em que o executado pode alegar quaisquer matérias dedutíveis no processo de conhecimento.

\footnotetext{
${ }^{486}$ Nos termos do artigo $733^{\circ}$, item 1, a suspensão da execução somente tem lugar quando o embargante prestar caução; tratando -se de execução fundada em documento particular, o embargante tiver impugnado a genuinidade da respetiva assinatura, apresentando documento que constitua princípio de prova, e o juiz entender, ouvido o embargado, que se justifica a suspensão sem prestação de caução; tiver sido impugnada, no âmbito da oposição deduzida, a exigibilidade ou a liquidação da obrigação exequenda e o juiz considerar, ouvido o embargado, que se justifica a suspensão sem prestação de caução.

${ }^{487}$ RIBEIRO, Flávia Pereira. A desjudicialização da execução civil. São Paulo: Saraiva, 2013, p. 142.
} 
O juiz poderá rejeitar liminarmente a oposição intempestiva, a que apresentar fundamento incompatível com o tipo de título e a que se revelar manifestamente improcedente. Caso a receba, o exequente é notificado para exercer contraditório também em 20 dias, tudo conforme artigo $817^{\circ}$ do Código de Processo Civil português.

Da decisão que encerra a oposição caberá apelação, oportunidade em que também deverão ser impugnadas eventuais decisões interlocutórias proferidas ao longo deste procedimento, nos termos do artigo $853^{\circ}$ do NCPCp.

Mantida a execução, o artigo $748^{\circ}$ do NCPCp prevê que a secretaria comunicará o agente executivo de que deve iniciar os atos de penhora, o que fará respeitando uma cláusula geral de proporcionalidade e adequação entre o patrimônio do devedor e o direito de adimplemento do credor ${ }^{488}$.

Os agentes de execução são responsáveis pela administração e alimentação de um sistema denominado "registro informático de execuções", previsto no supracitado artigo $748^{\circ}$ do NCPCp.

Trata-se de um banco de dados em que são inseridas informações dos executados que sejam úteis à persecução de seus patrimônios, tais como processos de execução pendentes, findos e suspensos, informações sobre penhoras efetivadas e fracassadas, lista de bens já penhorados, dentre outros ${ }^{489}$.

O próprio agente executivo, antes de iniciar os atos de penhora, deve realizar busca neste sistema e, a depender do resultado, adotar uma determinada postura.

Caso encontre outras execuções contra o mesmo devedor encerradas nos últimos três anos sem integral cumprimento, prevê o item 3 do artigo $748^{\circ}$ do NCPCp que o agente deve buscar patrimônio do executado por meio de sistemas informatizados da administração

${ }^{488}$ LEBRE DE FREITAS, José. A ação executiva à luz do Código de Processo Civil de 2013. 6 ed. Coimbra: Coimbra Editora, 2014, p. 186.

${ }^{489}$ RIBEIRO, Flávia Pereira. A desjudicialização da execução civil. São Paulo: Saraiva, 2013, p. 144. 
tributária, segurança social, registros cíveis, imóveis, automóveis, atividade comercial, dentre outros, aos quais tem acesso independentemente de autorização judicial. Informa o resultado ao exequente, que poderá realizar diligências próprias e informar ao agente a localização de eventual patrimônio. Não sendo informados bens de localização concreta, o mesmo diploma legal prevê a extinção automática da execução. Após nova notificação do executado, é incluída numa lista pública de execuções frustradas ${ }^{490}$, onde fica por 5 anos ou até que o executado salde sua dívida ${ }^{491}$.

Se o agente encontra outra execução em andamento contra o mesmo executado, deve verificar se é caso de remeter o requerimento executivo para aquele outro processo, a fim de se estabelecer um concurso de créditos - conforme artigo $748^{\circ}$, item 4 do NCPCp.

Caso o agente encontre patrimônio, deve realizar a penhora respeitando uma ordem legalmente estabelecida no artigo $751^{\circ}$, item 1 do Código de Processo Civil português, independentemente da ordem indicada pelo exequente no requerimento inicial. A preferência legal se inicia com os depósitos bancários. Para penhorá-los, o próprio agente de execução pratica todos os atos de forma eletrônica, tudo conforme artigo $780^{\circ}$ do NCPCp.

Também pelo agente executivo e de forma eletrônica são as penhoras de bens móveis e imóveis, remetendo-se comunicado para o órgão de registro competente. O agente ou pessoa que ele indicar - somente podendo ser o executado se o exequente anuir - será fiel depositário dos bens móveis não sujeitos a registro, nos termos do artigo $764^{\circ}$ do NCPCp.

A penhora que se afigurar ilegal, quer seja por violação aos seus limites objetivos ataque a bens sobre os quais não poderia ter recaído -, quer seja por violação aos seus limites subjetivos - ataque a bens não pertencentes ao executado -, é impugnável por oposição à

\footnotetext{
${ }^{490}$ A lista pública de execuções é regulamentada pela Portaria no 279/2013 e consiste em uma lista eletrônica de dados, disponível na Internet através do endereço eletrônico de acesso público http://www.citius.mj.pt, mecanismo auxiliar na deteç̧ão de situações de dívidas cuja cobrança se afigura inútil, prevenindo, assim, o acionamento injustificado do processo executivo através do fornecimento público de elementos sobre a capacidade de adimplemento dos interessados.

${ }^{491}$ Conforme artigo $6^{\circ}$, item 4 da Portaria $\mathrm{n}^{\circ}$ 279/2013.
} 
penhora, meio de defesa que, conforme o caso, pode ser alegada de forma incidental na própria execução, através de simples requerimento ${ }^{492}$ ou incidente próprio $^{493}$ ou ainda por meio de ações de conhecimento autônomas, casos dos embargos de terceiro e das ações reivindicatórias ${ }^{494}$.

A alienação dos bens penhorados, quando necessária, conta com uma ampla gama de modalidades ${ }^{495}$, tanto judicializadas ${ }^{496}$ quanto desjudicializadas ${ }^{497}$, escolhida, em regra, pelo agente executivo, ouvidos exequente e executado - conforme artigo $812^{\circ}$, item 1 do NCPCp - e preferindo-se o leilão eletrônico ${ }^{498}$.

Extinta a execução por qualquer de seus meios - destaque-se a extinção pela satisfação da execução e a supracitada possibilidade de extinção por inutilidade da lide, conforme resultado das pesquisas do agente de execução - o agente comunica o fato ao tribunal, aguarda o decurso de prazos recursais e demais formalidades, e realiza o

\footnotetext{
${ }^{492}$ Conforme, a título de exemplo, o caso do item 3 do artigo $764^{\circ}$ do NCPCp, "presume -se pertencerem ao executado os bens encontrados em seu poder, mas, feita a penhora, a presunção pode ser ilidida perante o juiz, quer pelo executado ou por alguém em seu nome, quer por terceiro, mediante prova documental inequívoca do direito de terceiro sobre eles, sem prejuízo da faculdade de dedução de embargos de terceiro. ”.

${ }^{493}$ Conforme previsão do artigo $784^{\circ}$ e seguinte do NCPCp, tem lugar o incidente quando for constatada a inadmissibilidade da penhora dos bens concretamente apreendidos ou da extensão com que ela foi realizada; a imediata penhora de bens que só subsidiariamente responderiam pela dívida exequenda; e a incidência da penhora sobre bens que, não respondendo pela dívida exequenda, não deveriam ter sido atingidos pela diligência.

${ }^{494}$ LEBRE DE FREITAS, José. A ação executiva à luz do Código de Processo Civil de 2013. 6 ed. Coimbra: Coimbra Editora, 2014, p. 312.

${ }^{495}$ O NCPCp prevê em seu artigo $811^{\circ}$, item 1 , sete modalidades possíveis para alienação dos bens, quais sejam: $a$ ) Venda mediante propostas em carta fechada; $b$ ) Venda em mercados regulamentados; $c$ ) Venda direta a pessoas ou entidades que tenham direito a adquirir os bens; $d$ ) Venda por negociação particular; $e$ ) Venda em estabelecimento de leilões; $f$ ) Venda em depósito público ou equiparado; $g$ ) Venda em leilão eletrónico.

${ }^{496}$ Caso das vendas mediante proposta em carta fechada que, nos termos do item 3 do artigo $800^{\circ}$ do NCPCp, se dá perante o juiz da execução quando se trata de bem imóvel.

${ }^{497}$ Caso das vendas feitas por estabelecimento de leilão - artigo $834^{\circ}$ do NCPCp - e da modalidade preferencial, de leilão eletrônica, nos termos do

${ }^{498} \mathrm{Cf}$. artigo $837^{\circ}$, item 1 do NCPCp. A venda por leilão eletrônico é regulamentada pela já citada Portaria ${ }^{\circ}$ 282/2013. A caracterização desta modalidade como desjudicializada ou não depende unicamente de um despacho do membro do Governo responsável pela Justiça, o qual definirá qual será a entidade gestora da plataforma eletrônica onde se passam os atos de alienação - cf. artigo 21 da Portaria. A despeito disso, o agente de execução é quem acompanha os atos de alienação também na modalidade eletrônica, sendo responsável pela decisão de adjudicação dos bens arrematados - cf. artigo $26^{\circ}$ da Portaria.
} 
arquivamento eletrônico do processo, sem necessidade de intervenção judicial, tudo conforme artigo $849^{\circ}$ do NCPCp.

\subsection{Rito sumário}

Nos casos em que tiver lugar o rito sumário, nos termos do artigo $855^{\circ}$ do $\mathrm{NCPCp}$, o requerimento executivo é encaminhado diretamente, por via eletrônica, para o agente de execução, ocasião em que, sem não recusar a designação, a ele incumbe o juízo de admissibilidade acerca da regularidade formal do requerimento executivo, tal como previsto, no rito ordinário, para a secretaria do Tribunal, podendo, fundamentadamente, recusá-lo nos termos do artigo $725^{\circ}$ do NCPCp.

Se, neste mesmo juízo, o agente executivo identificar indícios de alguma das hipóteses de indeferimento, tais como aquelas previstas no artigo $724^{\circ}$, itens 2 e 4 do NCPCp, apreciadas pelo juiz no rito ordinário, ou então tenha dúvidas sobre o cabimento do rito sumário, o agente remete os autos ao juiz executivo para deliberação e decisão ${ }^{499}$.

Recebido o requerimento, prevê o item 4 do artigo $855^{\circ}$ do NCPCp que o agente, desde logo, inicia as consultas prévias à penhora antes da citação do executado, podendo ter lugar a extinção pela ausência de patrimônio, nos termos descritos no rito ordinário.

Sendo localizados e penhorados bens, o executado é citado, oportunidade em que poderá se opor, simultaneamente, à penhora e à execução por meio de embargos. Aqui, como já há penhora, os embargos têm efeito suspensivo independentemente de caução ${ }^{500}$.

Eventual procedência da oposição, gera responsabilidade do exequente por eventuais danos culposos causados pela ausência da "prudência normal" exigida para os atos, sendo devida ao executado multa de $10 \%$ sobre o valor da execução, conforme previsto no artigo $858^{\circ}$ do NCPCp.

${ }^{499}$ LEBRE DE FREITAS, José. A ação executiva à luz do Código de Processo Civil de 2013. 6 ed. Coimbra: Coimbra Editora, 2014, p. 427.

${ }^{500}$ Ibidem, p. 428. 


\section{CAPÍtULO 03}

\section{ELEMENTOS PARA A DESJUDICIALIZAÇÃO DO MODELO BRASILEIRO DE EXECUÇÃO POR QUANTIA}

Neste terceiro capítulo, pretende-se projetar um modelo geral, desjudicializado, de execução por quantia, avaliando seu potencial de melhoria para o atual quadro do Poder Judiciário.

Para tanto, inicialmente enfrentaremos sua viabilidade diante das características das bases do devido processo legal executivo brasileiro discriminadas no capítulo primeiro, para, em seguida, avaliar algumas peculiaridades de um hipotético procedimento desta natureza adaptado ao contexto nacional.

\subsection{A viabilidade}

A análise da viabilidade dos modelos desjudicializados de execução por quantia aqui desenvolvida leva em consideração os parâmetros já delineados pelo ordenamento e pela doutrina nacionais em termos de monopólio e inafastabilidade de jurisdição, imparcialidade e naturalidade dos agentes envolvidos na execução e contraditório e ampla defesa.

Em que pese cada item ser analisado individualmente, ressalte-se que eles são elementos de uma única noção de devido processo legal, de modo que um procedimento desjudicializado deve atentar para todos estes aspectos em conjunto para que se legitime.

A intenção, portanto, não é abordar a desjudicialização como forma de completa ruptura do sistema já estabelecido, mas sim entender de que forma ela pode ser aplicada e, ainda assim, ser mantida a estruturação legal do processo tal como concebida para a tutela 
jurisdicional ${ }^{501}$, com os mesmos parâmetros entendidos voltados para o cumprimento dos deveres do Estado ${ }^{502}$, conforme previamente destacados no capítulo primeiro.

Trata-se de buscar, fora do Poder Judiciário, um processo equivalente ao dele, com as adaptações que se revelarem pertinentes no âmbito da administração pública e com a "publicização" das atividades dos particulares ${ }^{503}$ tanto quanto for necessária para que se aproxime da jurisdição de direito público ${ }^{504}$ hoje praticada.

Após esta primeira etapa, o passo seguinte é entender quais contribuições a desjudicialização pode trazer para a aceleração do processo e quais os riscos que se corre em termos de segurança processual.

Tendo isso em vista, passemos ao desenvolvimento dos itens.

\subsubsection{Monopólio e inafastabilidade de jurisdição}

Neste subitem pretende-se enfrentar a garantia constitucional de se levar ao Poder Judiciário qualquer lesão ou ameaça de lesão a direito. Intenciona-se analisar os limites, em termos de monopólio de jurisdição, do modelo desjudicializado como meio exclusivo de se promover a execução e, também, como meio alternativo de fazê-lo.

501 MARINONI, Luiz Guilherme. Ideias para um "renovado direito processual". In: CARNEIRO, Athos Gusmão; CALMON, Petrônio (org.). Bases científicas para um renovado direito processual. 2 ed. Salvador: Juspodivm, 2009, p. 131.

502 DOMBROSKI, Claudinei. Os princípios informadores da execução após a reforma do Código de Processo Civil. In: GUNTHER, Luiz Eduardo (coord.). Jurisdição: crise, efetividade e plenitude institucional. Curitiba: Juruá, 2009, p. 123.

${ }^{503}$ BARBOSA MOREIRA, José Carlos. Privatização do processo? Revista da EMERJ, Rio de Janeiro, v. 1, n. 3, p. 13/25, 1998, $\quad$ Disponível <http://www.emerj.tjrj.jus.br/revistaemerj_online/edicoes/revista03/revista03_13.pdf>, Acesso em 20 set. 2015 , p. 15.

504 ANDRADE, Érico. As novas perspectivas do gerenciamento e da "contratualização" do processo. Revista de processo, São Paulo, ano 36, vol. 193, mar. 2011, p. 173. 
Como já foi oportunamente demonstrado no segundo capítulo, a doutrina crítica à realização da execução fora do Poder Judiciário o faz a partir dos procedimentos já existentes no Brasil, oportunamente explanados no capítulo em referência.

Lá, pontuou-se como principais problemas no que concerne ao monopólio e inafastabilidade de jurisdição o argumento de que o inadimplemento do devedor configura lide, cuja solução deve se dar ou pela via da autocomposição ou pelo Poder Judiciário, já que não seria constitucionalmente possível atribuir função jurisdicional a autoridade administrativa ou particular ${ }^{505}$, daí ser vedado a estes agentes a prática de atos que impliquem a invasão patrimonial do executado, de forma unilateral, sem prévia decisão judicial.

Além disso, argumentou-se que a delegação de poder jurisdicional a agentes externos ao judiciário só seria admissível nas exceções expressamente previstas na Constituição Federal, dentre as quais não está prevista a execução ${ }^{506}$ - sequer a arbitragem poderia ser utilizada como argumento a endossar a conduta, haja vista que nem mesmo ao árbitro, terceiro imparcial, foi delegado o poder de império necessário à satisfação das decisões ${ }^{507}$.

Por fim, consignou-se que a ausência de parâmetros de imparcialidade do agente executivo faria com que o procedimento se conformasse como modalidade de autotutela ${ }^{508}$, a afastar o seu aspecto jurisdicional.

Diante disso, o estudo da desjudicialização e da amplitude de seu uso passa, primeira e necessariamente, pelo enfrentamento de tais argumentos. Seria possível a delegação de poder jurisdicional? Caso afirmativo, como fazê-lo? Ou, de outro modo, seria possível

\footnotetext{
${ }^{505}$ SANTOS, Ernane Fidélis dos. Alienação fiduciária de coisa imóvel. Revista Jurídica, Porto Alegre, vol. 47, n. 261, p.21-24, jul. 1999, p. 22.

${ }^{506}$ YOSHIKAWA, Eduardo Henrique de Oliveira. Execução extrajudicial e devido processo legal. São Paulo: Atlas, 2010, p. 114.

${ }^{507}$ Ibidem, p. 117; DENARDI, Volnei Luiz. Execuções judicial e extrajudicial no sistema financeiro da habitação. São Paulo: Editora Revista dos Tribunais, 2009, p. 127 e 128.

${ }^{508}$ GRINOVER, Ada Pellegrini. Novas tendências do direito processual de acordo com a Constituição de 1988. Rio de Janeiro: Forense Universitária, 1990, p. 200; YOSHIKAWA, Eduardo Henrique de Oliveira. Execução extrajudicial e devido processo legal. São Paulo: Atlas, 2010, p. 129; BECKER, L.A. Contratos bancários: execuções especiais. São Paulo: Malheiros, 2002, p. 319.
} 
preservar o poder jurisdicional no Judiciário e ainda assim contar com agentes executivos externos praticando a maioria da execução? Se sim, quais poderes poderiam ser delegados a estes agentes externos? Haveria diferenças significativas a depender se esse agente externo fosse privado ou público? Como efetivar estas alterações sem que se desnaturem as características jurisdicionais?

As respostas para tais indagações podem se iniciar com uma importante discriminação: nem todos os atos praticados na execução são jurisdicionais.

Conforme o conceito adotado ${ }^{509}$, jurisdição é uma expressão da soberania Estatal ${ }^{510}$ - e daí se dizer que ao Estado pertence o monopólio de jurisdição ${ }^{511}$ - que confere ao ente respectivo autoridade para, diante de um conflito, decidir imperativamente e impor decisões com vistas à pacificação social e realização do direito material ${ }^{512}$.

Deste conceito se extrai que nem todos os atos do processo são jurisdicionais ${ }^{513}$. Atos jurisdicionais são somente aqueles que tenham por objetivo direto "formular uma regra jurídica concreta" - a chamada cognição - ou "fazer atuar a regra jurídica concreta" - a execução ${ }^{514}$. Os demais atos, acessórios a estes, não têm natureza tipicamente jurisdicional. Assim, a título de exemplo, os atos que determinam pagamento sob pena de multa, que expedem ordem de penhora de um determinado bem, de busca e apreensão de bens ou de alienação de bem penhorado, porquanto atos com forte cunho impositivo, voltados para se fazer atuar a regra jurídica, são tipicamente jurisdicionais. $O$ mesmo se pode dizer, em vias de cognição, dos atos que resolvem embargos do executado, impugnação ao cumprimento de sentença e incidentes cognitivos durante a execução, porquanto decisões imperativas que formulam regra jurídica concreta.

\footnotetext{
${ }^{509}$ Sobre o conceito de jurisdição adotado v. Capítulo 1.

${ }^{510}$ CHIOVENDA, Giuseppe. Instituições de Direito Processual Civil. 4 ed. Campinas: Bookseller, 2009, p. 512. O autor coloca a jurisdição como uma das funções da soberania, ao lado das funções legislativa e administrativa.

511 SILVA, José Afonso da. Curso de Direito Constitucional positivo. 23 ed. São Paulo: Malheiros, 2004, p. 552.

512 DINAMARCO, Cândido Rangel. Execução civil. 8 ed. São Paulo: Malheiros, 2002, p.190.

${ }^{513}$ CINTRA, Antonio Carlos de Araújo; GRINOVER, Ada Pellegrini; DINAMARCO, Cândido Rangel. Teoria geral do processo. 29 ed. São Paulo: Malheiros, 2013, p. 185.

${ }^{514}$ ZAVASCKI, Teori Albino. Título executivo e liquidação. 2 ed. São Paulo: RT, 2001, p. 19.
} 
Os demais, como os atos de mero expediente e de preparação e cumprimento de ordens jurisdicionais, não se enquadram nesta categoria de atos, haja vista que, ainda que atuem em torno da soberania do Estado-juiz, não são, propriamente, manifestações desta soberania, mas sim meros desdobramentos da jurisdição já irradiada.

Esta distinção permite concluir que nem todo ato passível de desjudicialização é ato jurisdicional e, por conseguinte, nem toda desjudicialização exige discussão sobre o monopólio de jurisdição.

É possível, portanto, que um procedimento seja desjudicializado sem que se afete o monopólio de jurisdição: basta que os atos de cunho decisório e impositivo com vistas à solução do conflito permaneçam aos cuidados de um juiz e os demais atos - ou parte deles - sejam entregues aos cuidados de agentes externos ao Poder Judiciário.

Transplantando a ideia para as hipóteses de desjudicialização estudadas neste trabalho, pode-se dizer que o depósito, a administração, a avaliação pericial e a simples venda do bem já penhorado e com ordem de alienação, previstas no Código de Processo Civil, bem como, de modo geral, as desjudicializações incidentais dos procedimentos estrangeiros públicos judicializados abordados, são hipóteses de desjudicialização indiferentes ao monopólio de jurisdição. Inclusive, no ordenamento nacional, é possível até mesmo extrair autorização constitucional para este tipo de desjudicialização, a teor do inciso XIV do artigo 93 e caput do artigo 96, ambos da Constituição Federal, que preveem, respectivamente, a delegação da prática de atos sem conteúdo decisório aos servidores e a autonomia administrativa dos Tribunais.

Por outro lado, o Decreto-Lei $n^{\circ} 70 / 66$ e a Lei $n^{\circ}$ 9.514/97, assim como os modelos estrangeiros desjudicializados sueco, russo, francês e português, uma vez que contemplam agentes estranhos ao Poder Judiciário com poderes de decisão e imposição, já demandariam o enfrentamento da questão concernente ao monopólio de jurisdição. 
Neste particular, convém rememorar que o monopólio de jurisdição é decorrência da soberania do Estado e, portanto, a ele pertence ${ }^{515}$, e não ao Poder Judiciário. O Estado, por sua vez, delega jurisdição prioritariamente - e não exclusivamente - ao Poder Judiciário por meio da Constituição Federal.

Diz-se, por isso, que nem toda atividade jurisdicional está confiada ao Poder Judiciário, a despeito desta lhe ser sua função típica ${ }^{516}$. Por conseguinte, outros entes receberam essa função jurisdicional do Estado, ainda que em menor intensidade, naquilo que a doutrina convencionou denominar funções atípicas.

O Poder Legislativo, por exemplo, exerce função jurisdicional quando o Senado processa e julga o Presidente da República, os membros do Conselho Nacional de Justiça e do Conselho Nacional do Ministério Público, o Procurador-Geral da República e o Advogado-Geral da União por crimes de responsabilidade, nos termos do artigo 52, incisos I e II da Constituição Federal ${ }^{517}$.

Até mesmo a particulares já se admite a delegação de jurisdição. A arbitragem é frequentemente tratada como um meio alternativo de resolução de conflitos em que se exerce jurisdição por meio do poder conferido aos árbitros de decidir a lide em substituição à vontade das partes ${ }^{518}$, uma das vertentes da jurisdição. Esta posição foi reforçada principalmente após o advento da Lei n ${ }^{\circ} 11.232 / 2005$, que denominou "sentença" e conferiu

515 ALBERTON, Genacéia da Silva. Repensando a jurisdição conflitual. In: CARNEIRO, Athos Gusmão; CALMON, Petrônio (org.). Bases científicas para um renovado direito processual. 2 ed. Salvador: Juspodivm, 2009 , p. 287.

${ }^{516}$ MELLO, Celso Antônio Bandeira de. Curso de Direito Administrativo. São Paulo: Malheiros, 2010, p. 31. ${ }^{517}$ Ibidem, p. 33.

518 CARMONA, Carlos Alberto. A arbitragem no processo civil brasileiro. São Paulo: Malheiros, 1993, p. 34; SILVA, Fernanda Tartuce da. Mediação nos conflitos civis. São Paulo: Método, 2008, p. 84; CREMASCO, Suzana Santi; SILVA, Tiago Elder. O caráter jurisdicional da arbitragem e o precedente arbitral. Revista da Faculdade de Direito da Universidade Federal de Minas Gerais, Belo Horizonte, v. 59, junho-dezembro 2011 , p. 377; SICA, Heitor Vitor Mendonça. Velhos e novos institutos fundamentais do direito processual civil. In: ZUFELATO, Camilo; YARSHELL, Flávio Luiz (Org.) 40 anos da teoria geral do processo no Brasil: passado, presente e futuro. São Paulo: Malheiros, 2013, p. 435. 
status de título executivo judicial às decisões que põem fim aos processos arbitrais, conforme inciso IV do artigo 475-N do Código de Processo Civil ${ }^{519}$.

Neste sentido, a impossibilidade de imposição de decisões - outra das vertentes da jurisdição - que recai sobre os árbitros, configuraria restrição justificada por outros fundamentos que não o monopólio de jurisdição. Se o poder jurisdicional se desdobra nos poderes de decidir e de impor decisões e em sendo possível ao Estado delegar uma das vertentes, não há como se impossibilitar a delegação da outra vertente.

Tanto que parte da doutrina trata esta limitação não como questão de jurisdição, mas sim de competência, de restringir a atuação das Câmaras Arbitrais apenas e tão-somente à decisão da lide, sem possibilidade de avançar à concreção dessa decisão ${ }^{520}$, assim como se dá com os juízes de execução portugueses ou, em sentido contrário, com as varas de execuções penais do direito brasileiro ou com o agente de execução do direito português, aos quais são seriamente restritas as possibilidades de solução de lides a despeito da ampla liberdade conferida para a prática de atos impositivos.

Da mesma forma, também imbuídos de poder impositivo, mas com graves restrições quanto ao seu poder decisório, atuariam o oficial de registro de imóveis e o agente fiduciário dos procedimentos previstos pela Lei $n^{\circ}$ 9.514/97 e pelo Decreto-Lei $n^{\text {o }} 70 / 66^{521}$, respectivamente. A carga cognitiva da atuação destes profissionais se restringe, em essência, à verificação de requisitos, sem que a eles seja facultada a resolução de quaisquer controvérsias entre as partes. Sem prejuízo, lhes é conferido o poder de consolidar a propriedade em nome do credor - Lei $n^{\circ}$ 9.514/97 - ou designar o leilão - Decreto-Lei $\mathrm{n}^{\circ}$ 70/66 -, ou seja, ambos têm poderes para determinar a inversão da propriedade do bem,

519 DINAMARCO, Cândido Rangel. A arbitragem na teoria geral do processo. São Paulo: Malheiros, 2013, p. 41; CARMONA, Carlos Alberto. Arbitragem e processo. 3 ed. São Paulo: Atlas, 2009, p. 27.

${ }^{520}$ Giuseppe Chiovenda já registrava, expressamente, a separação entre cognição e execução como questão de competência, a ser fixada conforme critérios objetivos e territoriais (Instituições de direito processual civil. 4 ed. Campinas: Bookseller Editora, 2008, p. 718-719).

521 Pedro Vasconcellos registra posicionamento doutrinário que considera expressamente a atividade do Decreto-Lei no 70/66 como de atividade jurisdicional (Execução extrajudicial e judicial do crédito hipotecário no sistema financeiro da habitação. Rio de Janeiro: Livraria Francisco Alves Editora, 1976, p. 19). 
extraindo-a imperativamente do devedor para satisfazer a pretensão do credor e saldar a dívida.

É bem verdade que ainda existe grande polêmica em torno do assunto e que o caráter jurisdicional da arbitragem não é pacífico ${ }^{522}$, assim como são questionados o exercício de jurisdição pelo tabelião nas alienações fiduciárias ${ }^{523}$ e o próprio sentido moderno de jurisdição ${ }^{524}$. Estas questões impõem cautela ao se afirmar como jurisdição o exercício de atividade similar fora da atuação convencional do juiz perante o Poder Judiciário. A prudência demanda estudo dedicado e aprofundado para uma definição a este respeito, o que descabe nesta ocasião.

Porém, mesmo em meio à discussão, não se nega que aos árbitros é conferido poder de decidir imperativamente e, de forma análoga, ao oficial de registro de imóveis e ao agente fiduciário são conferidos poderes para impor o direito do credor, o que, coincidentemente ou não, são as duas vertentes essenciais da jurisdição. Diante disso, visando o desenvolvimento do trabalho, será mantida a terminologia "desjudicialização de atos jurisdicionais" aqui adotada com o intuito de se representar a transferência de atos de decisão

\footnotetext{
${ }^{522}$ Uma boa síntese da discussão doutrinária acerca do caráter jurisdicional da arbitragem pode ser extraída da dialética entre os trabalhos de Luiz Guilherme Marinoni e Fredie Didier Junior. O primeiro, adepto de corrente contrária ao caráter jurisdicional da arbitragem, afirma que a arbitragem nada mais é que a regulamentação da autonomia da vontade dos cidadãos para dirimir conflitos de direitos individuais disponíveis que lhes dizem respeito. Assim sendo, não se confundiria com jurisdição, notadamente ante as diferenças de investidura - 0 juiz somente exerce jurisdição após o ingresso por meio de concurso público -, indelegabilidade - a jurisdição não poderia ser delegada - e juiz natural - uma série de regras e garantias que visam um juiz previamente definido e imparcial (MARINONI, Luiz Guilherme. Curso de Processo Civil - Volume 1. 7 ed. São Paulo: Editora Revista dos Tribunais, 2013, p. 151-164). O segundo, adepto da corrente que afirma o caráter jurisdicional da arbitragem, defende que o instituto não decorre exclusivamente da vontade das partes, contando com a delegação de poderes feita pelo Estado por meio da Lei que a instituiu e pelo artigo $114, \S \S 1^{\circ}$ e $2^{\circ}$ da Constituição Federal. Ademais, não se trataria de mera delegação de jurisdição, mas sim autorização, feita pelo Estado, para exercício especial de jurisdição, o que já é feito em outras hipóteses constitucionalmente previstas. Por fim, as questões da investidura e naturalidade do árbitro seriam supridas pela seleção consentânea das partes (DIDIER JUNIOR, Fredie. Curso de direito processual civil - Volume 1. 14 ed. Salvador: Editora Juspodivm, 2012, p. 112-113).

${ }_{523}$ MARTINS, Samir José Caetano. A execução extrajudicial de créditos do sistema de financiamento imobiliário. Revista eletrônica de direito processual, Rio de Janeiro, ano 2, vol. II, jan.-dez. 2008, p. 299.

${ }^{524}$ Por todos, SICA, Heitor Vitor Mendonça. Velhos e novos institutos fundamentais do direito processual civil. In: ZUFELATO, Camilo; YARSHELL, Flávio Luiz (Org.) 40 anos da teoria geral do processo no Brasil: passado, presente e futuro. São Paulo: Malheiros, 2013, p. 435-437.
} 
imperativa e imposição a agentes externos ao Judiciário, mesmo que não se pretenda, com isso, afirmar uma jurisdição exercida fora do Poder Judiciário.

Assim, o exposto permite concluir que desjudicializar a execução não necessariamente implica em transferir atos jurisdicionais para particulares ou entes da administração pública. Esta preocupação somente recai em atos específicos, notadamente aqueles de conteúdo decisório imperativo ou impositivo.

Quanto a estes atos, o monopólio de jurisdição pertence ao Estado, que não restringiu este poder apenas ao Judiciário, tendo delegado esta fração de sua soberania a outros segmentos da organização social brasileira, notadamente o Legislativo e alguns particulares. Inexistindo exclusividade no exercício do poder jurisdicional - ou no exercício dos poderes de decidir imperativamente e de impor decisões - a reserva de jurisdição permite que o monopólio de jurisdição seja respeitado mesmo com a intervenção dos diversos agentes sociais $^{525}$, não só o Judiciário.

Desse modo, para fins de desjudicialização, o obstáculo que se impõe à desjudicialização em termos de monopólio de jurisdição é superável, bastando para tanto a edição de lei - em sentido amplo - que legitime a transferência deste poder do Estado para outro agente.

Diga-se, por oportuno, que a natureza do agente, aqui, é irrelevante. A transferência de atos tipicamente jurisdicionais pode ser feita a agentes privados ou administrativos indistintamente, desde que pela via legal. Naturalmente que, conforme a natureza do agente, serão necessárias mais ou menos adaptações para atender a outros aspectos necessários ao desenvolvimento de um devido processo legal, porém, para o monopólio de jurisdição em si, a autorização legal se revela suficiente.

525 GARSON, Samy. A adequação da ideia de monopólio de jurisdição com os meios alternativos de solução de litígios. Disponível em <www.sgaa.adv.br/downloads/a_monopolio.pdf>. Acesso em 02 out. 2012. 
Superada a questão do monopólio de jurisdição, cabe saber em que medida a inafastabilidade do controle jurisdicional se apresenta como entrave para a desjudicialização da execução.

Como visto, giza referido princípio que, a menos que haja dispositivo constitucional em sentido diverso, é sempre garantido o acesso livre e direto ao poder jurisdicional do Estado exercido pelo Poder Judiciário ${ }^{526}$. Esta previsão consta expressamente do texto do inciso XXXV do artigo $5^{\circ}$ da Constituição Federal, de modo que, ainda que se admita a transferência de poder jurisdicional a agentes não pertencentes ao Poder Judiciário, é imperioso que qualquer lesão ou ameaça de lesão a direito tenha livre caminho ao Poder Judiciário.

Frise-se que o texto constitucional não determina que todas as demandas devam ser resolvidas pelo Poder Judiciário, mas sim que a ele é garantido um poder residual para solução de controvérsias ${ }^{527}$. Na execução, considerando que o processo é desencadeado a partir de uma lesão ao direito do credor, o princípio da inafastabilidade do controle jurisdicional garante que, em regra, quando forem criados procedimentos executivos desjudicializados que prevejam a transferência de atos jurisdicionais, eles se apresentem como mecanismos meramente alternativos de se promover a execução, sendo garantido a este credor promover a execução de seu crédito perante o Poder Judiciário - mais especificamente, de obter a tutela jurisdicional executiva oferecida pelo Poder Judiciário se assim desejar. Em suma, pode-se dizer que o princípio veda procedimentos que impeçam ou condicionem a tutela executiva oferecida pelo Poder Judiciário.

Havendo uma via desjudicializada em que sejam praticados atos impositivos com vistas ao oferecimento de tutela executiva, a sua utilização depende única e exclusivamente de previsão legal e da vontade do exequente, assim como, em regra, ao demandante cabe a escolha entre procedimentos alternativos previamente prescritos em lei, como os de rito sumário, os juizados especiais e os procedimentos especiais em geral. Ademais, por se tratar

\footnotetext{
${ }^{526}$ LENZA, Pedro. Direito constitucional esquematizado. 17 ed. São Paulo: Saraiva, 2013, p. 1075.

${ }^{527}$ MANCUSO, Rodolfo de Camargo. A resolução dos conflitos e a função judicial no contemporâneo Estado de Direito. 2 ed. São Paulo: Editora Revista dos Tribunais, 2014, p. 169.
} 
de procedimento executivo, em que já há um direito reconhecido ao exequente aprioristicamente, a exigência de prévio consenso das partes na escolha do procedimento se afiguraria até mesmo contraditória, uma vez que o direito material, num primeiro momento, já pertence ao exequente, facultado ao executado apenas respostas aos comandos executivos.

A escolha, pelo exequente, da via desjudicializada alternativa com poder de decisão e imposição de decisões, impedirá que demande o mesmo crédito pela via judicializada, aplicável, analogicamente, o instituto da litispendência ${ }^{528}$. Esta escolha, porém, não tem o condão de impedir que o executado questione a execução perante o Judiciário, quer seja, por vias processuais próprias, como os embargos, quer seja por ação autônoma.

Para que este tipo de procedimento desjudicializado seja obrigatório e inevitável, ou seja, para que um procedimento executivo desjudicializado seja a única alternativa para execução, é necessária alteração constitucional que legitime esta via em excepcionalidade ao controle do Poder Judiciário do inciso XXXV do artigo $5^{\circ}$ da Constituição Federal, sendo até mesmo questionável a constitucionalidade de tal alteração ante a restrição insculpida no inciso IV, $\S^{\circ}$ do artigo 60 da Constituição Federal, que veda a edição de emendas constitucionais tendentes a abolir direitos e garantias fundamentais.

Já quando a desjudicialização for de atos não jurisdicionais, ou seja, atos sem conteúdo decisório ou impositivo, entende-se que, sem prejuízo de ser possível a sua criação como uma alternativa, não há qualquer óbice para que o procedimento desjudicializado seja obrigatório. Isto porque, pela regra constitucional, o que não pode ser impedido é o acesso ao Poder Judiciário para obtenção de tutela jurisdicional, isto é, a devida apreciação e solução da respectiva lesão ou ameaça de lesão pelo agente ali encarregado, no caso, o juiz. Recaindo a desjudicialização sobre atos não jurisdicionais, a tutela proferida pelo Poder Judiciário estará preservada, motivo pelo qual o princípio da inafastabilidade não é afetado.

Estes são os aspectos concernentes à tutela dos direitos do exequente. A questão da inafastabilidade do poder jurisdicional diante de lesões e ameaças de lesões a direitos do

528 SOARES NETO, Júlio. Direito registral e arbitragem: a nova jurisdição extrajudicial. Curitiba: Juruá, 2010, p. 92. 
executado quando o procedimento envolve desjudicialização de poder jurisdicional será oportunamente desenvolvida abaixo, no item sobre contraditório e ampla defesa.

Conclui-se, pois, quanto ao princípio da inafastabilidade do controle jurisdicional, que, no Brasil, em razão da previsão constitucional do inciso XXXV do artigo $5^{\circ}$, eventual procedimento executivo desjudicializado, em regra, deverá ser apenas alternativo ao procedimento judicializado. Para que seja obrigatório o procedimento desjudicializado, é necessária ou alteração constitucional ou que sejam desjudicializados apenas atos sem conteúdo jurisdicional.

Diante desta interpretação, tem-se, num primeiro momento, também quanto à inafastabilidade do controle jurisdicional, a exemplo do que já ocorrera com o monopólio de jurisdição, a compatibilização dos procedimentos executivos previstos pelo Decreto-Lei $\mathrm{n}^{\circ}$ 70/66 e pela Lei $n^{\circ} 9.514 / 97$, já que em ambos os casos o procedimento desjudicializado é alternativo ao procedimento praticado dentro do Poder Judiciário.

Finalmente, há de se ressalvar que toda e qualquer via processual para se mover a execução deve respeitar os ditames da isonomia, sendo acessível a todos, de forma ampla e irrestrita. Qualquer lesão ou ameaça de lesão a direito deve ter caminho livre para ser levada a exame e solução pela via do procedimento cabível.

Isso não impede que um procedimento seja destacado para a solução de apenas determinados tipos de crédito ou para direitos pertencentes a determinados titulares ou devedores. É o que a doutrina denomina de sistema pluriprocessual de conflitos, em que um determinado ordenamento conta com processos com características específicas voltadas à adequação das particularidades de cada tipo de caso, como forma de se reduzir as ineficiências ${ }^{529}$. Todavia, nestes casos é necessário que a discriminação seja fundada na

\footnotetext{
${ }^{529}$ MANCUSO, Rodolfo de Camargo. A resolução dos conflitos e a função judicial no contemporâneo Estado de Direito. 2 ed. São Paulo: Editora Revista dos Tribunais, 2014, p. 156.
} 
desigualdade das questões que a justificam e que, dentro da categoria destacada, o acesso seja garantido a todos ${ }^{530}$.

Assim é que se legitima, por exemplo, um procedimento alternativo para a execução de um crédito proveniente de um contrato de alienação fiduciária - caso da Lei $\mathrm{n}^{\circ}$ 9.514/97 - em que somente um tipo específico de crédito, necessário para a impulsão de uma política habitacional nacional, goza de um procedimento alternativo para execução. O mesmo se dá com o procedimento de execução dos créditos da Fazenda Pública - Lei nº 6830/80 -, em que créditos titularizados pelo Poder Público, porquanto revestidos de interesse público, também usufruem de procedimento específico.

Do mesmo modo, não há impedimento para que um procedimento destacado preponderantemente desjudicializado perante instituição privada, por exemplo - tenha custo maior ou menor do que o judicializado. Basta que a discriminação seja justificada enquanto medida de isonomia e que a discrepância não impeça o acesso universal dos legitimados para utilização do procedimento.

Desta feita, estabelecidos os parâmetros acerca dos limites para a desjudicialização da execução quanto ao monopólio e à inafastabilidade de jurisdição, pode-se avançar para questão intrinsecamente relacionada: a imparcialidade e naturalidade dos agentes encarregados da execução.

${ }^{530}$ PASSOS, J. J. Calmon de. A crise do poder judiciário e as reformas instrumentais: avanços e retrocessos. Revista Eletrônica sobre a Reforma do Estado, n. 3, set.-nov. 2005, Salvador, Disponível em <http://www.direitodoestado.com/revista/RERE-3-SETEMBRO-2005-CALMON\%20DE\%20PASSOS.pdf〉. Acesso em 15 nov. 2014, p. 10. 


\subsubsection{Imparcialidade e naturalidade dos agentes envolvidos na execução}

Como visto, a prestação jurisdicional deve respeitar a isonomia, que deve operar tanto na estruturação do processo, ainda na via legislativa, quanto na atuação do juiz e de seus auxiliares.

Neste cenário, uma das principais garantias de um processo isonômico é a imparcialidade, forma qualificada do princípio da impessoalidade a que está submetida toda a administração pública, e que tem por objetivo que o Estado-juiz atue com uma indiferença inicial quanto ao caso concreto e às pessoas nele envolvidas ${ }^{531}$.

Esta imparcialidade é obtida por três vias essenciais, quais sejam, as independências do Poder Judiciário e de seus magistrados, obtidas a partir de prerrogativas institucionais e funcionais de cada um, respectivamente, e o princípio do juiz natural.

A independência do Poder Judiciário decorre do tratamento dado pela Constituição, que garante seu autogoverno administrativo e financeiro e traça limites na intervenção entre os Poderes - sistema de freios e contrapesos -, de modo a restarem vedadas outras intervenções que excedam estas hipóteses.

Já a independência dos magistrados advém da vitaliciedade, inamovibilidade e irredutibilidade de subsídios, bem como a definição, já nos regramentos dos artigos 93 e 94 da Constituição Federal, dos critérios para ingresso e promoção na carreira da magistratura ${ }^{532}$. Ainda, vedações como as de acumulação de cargos e de recebimento de custas ou participação em processos, expressas no parágrafo único do artigo 95 da Constituição Federal, compõem a independência e imparcialidade da magistratura.

Finalmente, a garantia do juiz natural, pela qual às partes é devido o julgamento por juiz prévia e devidamente investido na função, aleatoriamente designado para o caso, conforme regras de competência previamente estabelecidas, vedado tribunal de exceção.

531 DINAMARCO, Cândido Rangel. Instituições de Direito Processual Civil - Volume I. 7 ed. São Paulo: Malheiros, 2013, p. 206.

532 Ibidem, p. 207. 
No que concerne à imparcialidade dos auxiliares da justiça, em que pese haver um dever geral de atende-la, podendo estes agentes serem responsabilizados pela eventual violação, diferentemente do que se passa com os juízes, não há mecanismos criados especificamente para atender ao preceito. $\mathrm{O}$ fato de não praticarem atos jurisdicionais $\mathrm{e}$ estarem subordinados às determinações do juiz parecem suficientes para que a legislação não se preocupe em demasia com mecanismos de garantia à imparcialidade, bastando um dever geral de respeito e a possibilidade de alegação pelos interessados.

Diante deste cenário, a primeira conclusão que se pode extrair é que a desjudicialização de atos não jurisdicionais pouco afeta a imparcialidade do processo executivo, independentemente do tipo de desjudicialização praticada.

A legislação nacional inclusive já convive harmonicamente com a prática de atos processuais não jurisdicionais por agentes públicos - auxiliares permanentes - e por agentes privados - auxiliares eventuais.

Esta constatação permite afirmar que, na desjudicialização administrativa de atos não jurisdicionais, a imparcialidade pode a atuar do mesmo modo que hoje se passa com os auxiliares permanentes. Isto porque as autonomias financeira e administrativa do Judiciário, únicos mecanismos voltados à garantia de imparcialidade que afetam estes profissionais, também existem nos demais Poderes, os quais possuem, inclusive, maior controle sobre o aspecto orçamentário do que o Judiciário, deficitário e dependente de aportes para sua manutenção ${ }^{533}$. No mais, em nada diferem, em termos de imparcialidade, os servidores do Poder Judiciário e os servidores dos demais Poderes, sendo todos agentes públicos.

Suas investiduras, ao menos para as atividades constantemente requisitadas, tendem a se dar por concurso público, regra prevista para o setor público, nos termos do artigo 37 da Constituição Federal. Aquelas menos requisitadas podem ser objeto de contratações 
pontuais, respeitada a modalidade licitatória cabível ou, caso o custeio seja feito diretamente pela parte, por intermédio do próprio credenciamento hoje utilizado no Poder Judiciário.

Em se tratando da remuneração do serviço e de seus agentes, também é possível a adoção de modelo praticamente idêntico ao que hoje é empregado no Poder Judiciário, qual seja, de custeio pelo Estado, sem prejuízo da cobrança de custas e valores referentes a honorários e diligências. Destaque-se que a remuneração realizada diretamente pela parte, como se dá hoje, por exemplo, com os leiloeiros e os peritos, não configura entrave à imparcialidade desde que haja limitações impostas ou pela lei ou pelo detentor do poder jurisdicional, respeitadas as peculiaridades quanto à remuneração destes últimos.

$\mathrm{Na}$ desjudicialização privada de atos não jurisdicionais, por sua vez, a imparcialidade pode a atuar da mesma forma que hoje se passa com os auxiliares eventuais, tendo em vista que o dever geral imposto, aliado à possibilidade de alegação de suspeição ou impedimento pelos interessados, parecem bastar para garantir o preceito quando agentes privados são chamados a atuar no processo.

Para a investidura destes agentes pode-se adotar a mesma modalidade de credenciamento perante o órgão investido de jurisdição quando houver desjudicialização de atos menos requisitados, como são, em geral, aqueles praticados pelos auxiliares eventuais. Já para atos frequentes, como juntadas, aberturas de vista, intimações e movimentações processuais análogas, a manutenção da investidura por credenciamento exigirá que os habilitados ofereçam estrutura maior, suficientes para a condução do processo. O ideal é que sejam criados escritórios capazes de congregar a realização de todos os atos que forem delegados, uma vez que a iniciativa privada goza de maior flexibilidade para a contratação de pessoas e serviços, tendo maior facilidade para se adequar às demandas.

A remuneração é ponto essencial da desjudicialização privada. Em se tratando de repasse de atividades públicas para a iniciativa privada, é necessário que haja viabilidade econômico-financeira do empreendimento, sob pena ou de se inviabilizar o negócio ou de torna-lo oneroso ao Estado, que teria de socorrer a atividade ou extingui-la. Assim, qualquer que seja a configuração da desjudicialização privada, com transferência de atos jurisdicionais ou não, é indispensável um estudo prévio de viabilidade econômico-financeira que defina a forma de remuneração, a pessoa responsável pelo pagamento, o nível de 
liberdade do agente executivo para alterar os valores ${ }^{534}$ e a sua compatibilidade com o tipo de encargo atribuído ${ }^{535}$.

Tendo isso em conta, dentre as formas possíveis de remuneração, pode-se considerar, novamente, o modelo utilizado com os auxiliares eventuais. Ganha importância o custeio feito diretamente pelos interessados, aqui também necessária a limitação dos valores em lei ou por meio de ato do detentor do poder jurisdicional de forma a garantir a imparcialidade $\mathrm{e}$ isonomia dos agentes, a exemplo do que hoje é feito com o leiloeiro ou perito avaliador. Ainda, pode haver remuneração por meio de emolumentos e percentuais dos créditos recuperados, bem como subsídios do Estado, tudo a depender do estudo de viabilidade econômica supracitado.

Estes aspectos consignados para a desjudicialização de atos não jurisdicionais sofrem alteração quando o objeto de análise é a desjudicialização de atos jurisdicionais. Isto porque toda a estrutura pensada e criada para a imparcialidade, desde a independência conferida ao Poder Judiciário, passando pelas garantias de inamovibilidade, vitaliciedade e irredutibilidade de subsídios, critérios para ingresso na carreira e princípio do juiz natural, têm foco na atividade desenvolvida por estes agentes.

Neste contexto, o transplante de estrutura ao menos similar para a via desjudicializada seria o pensamento natural. Em se tratando de desjudicialização administrativa, não há grandes óbices em se projetar um agente dotado de poder decisório e impositivo integrando órgão, ainda que vinculado ao Poder Executivo, independente do restante da administração, com autonomias financeira e administrativa. Sua investidura, feita por concurso público, lhe provendo cargo dotado de inamovibilidade, irredutibilidade de subsídios e vitaliciedade, blindando-o de quaisquer influências que possam afetar seu poder de decisão. Sua designação, dentre outros agentes investidos previamente do mesmo poder, feita de forma aleatória, em sistema de distribuição. Sua remuneração garantida pelo Estado,

${ }^{534}$ UZELAC, Alan. Privatization of enforcement services - A step forward for countries in transition? In: VAN RHEE, C.H.; UZELAC, Alan (coord.). Enforcement and enforceability - tradition and reform. Antwerp, Oxford, Portland: Intersentia, 2010, p. 98.

535 CENEVIVA, Walter. Lei dos notários e dos registradores comentada (Lei n. 8935/94). 6 ed. São Paulo: Saraiva, 2007, p. 170. 
tornando-o independente de subsídios do exequente ou da remuneração atrelada à recuperação do crédito.

Considerando esta estrutura, críticas como as voltadas aos projetos de lei de reforma da execução fiscal, quanto à independência e imparcialidade dos agentes executivos, quer sejam aqueles incumbidos de todo o processo executivo - no Projeto $n^{\circ}$ 2412/07 -, quer sejam os responsáveis pelo procedimento preparatório - no Projeto $n^{\circ}$ 5080/2009 - se revelam superáveis. Os mencionados mecanismos voltados à imparcialidade permitiriam uma segmentação entre órgão executor e exequente, de modo a não se configurar a autotutela apontada pela doutrina e de forma a romper com o liame hierárquico entre o órgão executor e o restante da administração ${ }^{536}$.

Todavia, quando se projeta a desjudicialização privada de atos jurisdicionais, não há como prevalecer a mesma estrutura hoje aplicada ao Poder Judiciário. A começar pelas autonomias financeira e administrativa da pessoa jurídica à qual o agente será vinculado. Se, no Poder Público, estas características são sinônimos de independência e autogoverno do órgão, voltadas à consecução mais pura possível de um determinado interesse público, na iniciativa privada são aspectos inatos à autonomia da vontade, mas que tendem ao distanciamento de escopos sociais: quanto maiores as autonomias administrativa e financeira de um determinado segmento econômico, maior a incerteza quanto ao comprometimento da atividade com um propósito que não seja o lucro.

Neste contexto, qualquer tentativa de se prover estrutura similar à Judiciária para fins de imparcialidade demandará forte interferência do Estado nesta atividade econômica, de modo a restringir esta autonomia tanto no aspecto financeiro, com regras para a capitalização e custeio da atividade, quanto administrativo, com mecanismos de controle do exercício profissional destes agentes, notadamente no que concerne à investidura e remuneração destes

536 SICA, Heitor Vitor Mendonça. Perspectivas atuais da "Teoria Geral do Processo". In: CARNEIRO, Athos Gusmão; CALMON, Petrônio (org.). Bases científicas para um renovado direito processual. 2 ed. Salvador: Juspodivm, 2009, p. 70. 
profissionais $^{537}$, aspectos mais sensíveis ao tema. Sem qualquer contradição, pode-se dizer que a independência necessária ao agente executivo com função jurisdicional ${ }^{538}$ depende de regras restritivas ao seu exercício.

A vitaliciedade e inamovibilidade podem ser vislumbradas no âmbito privado, ou seja, é possível que se confira a um profissional privado, uma vez investido como agente executivo dotado de poderes de decisão e imposição, as garantias de não perder a função senão por decisão judicial e nem ser transferido sem relevante interesse público. Já a irredutibilidade de subsídios é garantia descabida, tendo em vista a natureza jurídica da atividade, sujeita às oscilações de mercado.

O princípio do juiz natural dependeria da investidura prévia dos agentes na função, inexistindo surpresas a exequente e executado, podendo ser designado a partir de sistema de aleatoriedade, como a distribuição hoje praticada no Judiciário. Aqui se apresenta também a possibilidade de constituição de agente executivo por convenção das partes, mediante escolha consensual dentre uma lista de agentes previamente habilitados, dispensando-se a aleatoriedade, tal como é feito, hoje, na arbitragem. Esta modalidade, contudo, deve ser vista com ressalvas, já que, em se tratando de obrigações de pagar quantia, notadamente nos títulos extrajudiciais, como aqueles decorrentes de financiamentos e empréstimos bancários, o devedor se encontrará em situação de vulnerabilidade, o que coloca em cheque sua plena liberdade para contratar.

Esta, inclusive, é uma das críticas feitas à imparcialidade do agente fiduciário no Decreto-Lei $n^{\circ} 70 / 66$. A doutrina acusa que a investidura do agente fiduciário por meio de nomeação consentânea das partes no contrato de financiamento não provê garantia de

${ }^{537}$ UZELAC, Alan. Privatization of enforcement services - A step forward for countries in transition? In: VAN RHEE, C.H.; UZELAC, Alan (coord.). Enforcement and enforceability - tradition and reform. Antwerp, Oxford, Portland: Intersentia, 2010, p. 93; HESS, Burkhard. Different enforcement structures. In: VAN RHEE, C.H.; UZELAC, Alan (coord.). Enforcement and enforceability - tradition and reform. Antwerp, Oxford, Portland: Intersentia, 2010, p. 55.

${ }^{538}$ DINAMARCO, Cândido Rangel. A arbitragem na teoria geral do processo. São Paulo: Malheiros, 2013, p. 27. 
imparcialidade, haja vista as peculiaridades decorrentes do próprio negócio, tais como a recorrente utilização de contratos de adesão, o conhecimento prévio que a instituição já tem do mercado de agentes fiduciários e o fato de tais profissionais pertencerem todos ao mesmo ramo de negócios do credor, fatores que indicam que o mutuário não tem real disponibilidade sobre o contrato ${ }^{539}$. Trata-se de hipótese típica em que o devedor está em condição de hipossuficiência, sem reais possibilidades de negociação, de modo que tampouco a imparcialidade do agente executivo estaria garantida.

Do exposto, em suma, pode-se afirmar que o quadro geral acerca da desjudicialização privada de atos jurisdicionais indica que a impossibilidade de reprodução das estruturas aplicadas no Judiciário traz a reboque uma reformulação das estruturas para garantia da imparcialidade.

A assertiva pode ser ilustrada com o exemplo português. Como se pôde observar, nas sucessivas reformas portuguesas, quanto maior a desjudicialização privada, quanto mais funções jurisdicionais eram entregues aos agentes de execução, mais mecanismos de controle eram empregados. Rememore-se que, em uma primeira etapa da reforma, foram delegados apenas atos não-jurisdicionais, oportunidade em que o juiz permaneceu com poder geral de controle sobre o processo; em seguida, houve uma ampla desjudicialização de atos jurisdicionais, remanescendo ao juiz apenas a solução de eventuais conflitos, trazendo a reboque a criação da Comissão para Eficácia das Execuções como fiscalizadora dos agentes executivos; finalmente, no modelo atual, com uma atuação híbrida do juiz, ora atuando diretamente na execução, ora na solução de conflitos, mantido e aperfeiçoado o órgão de controle dos agentes executivos.

\footnotetext{
${ }^{539}$ DENARDI, Volnei Luiz. Execuções judicial e extrajudicial no sistema financeiro da habitação. São Paulo: Editora Revista dos Tribunais, 2009, p. 116.
} 
$\mathrm{Na}$ França, de modo similar, a atuação dos huissier de justice é supervisionada e controlada pelo órgão de classe destes profissionais e pelo Ministério Público, além de os atos e responsabilidades serem objeto de controle pelo juge de l'exécution.

No Brasil, o profissional que foi destinatário de desjudicialização de atos jurisdicionais executivos e mais se aproxima dos exemplos estrangeiros é o tabelião, profissional privado que exerce, também em regime privado, função pública ${ }^{540}$. Ainda assim, a estrutura que lhe é disponibilizada para fins de imparcialidade não equivale exatamente à do juiz.

Historicamente, a função notarial tem conexões com a administração da justiça, daí decorrendo o dever de imparcialidade ${ }^{541}$. Logo, em que pese ser remunerado pelo contratante do serviço, o tabelião não deve defender os interesses dele, mas sim assessorar todas as partes envolvidas no ato realizado. Diz-se, por isso, que o tabelião é o "advogado do ato jurídico realizado, nisto assessorando todas as partes, e nenhuma em especial" ${ }^{\prime 542}$.

O dever de imparcialidade que lhe é imposto, é promovido por mecanismos como a investidura por meio de concurso público, a inamovibilidade enquanto mantido bom comportamento $^{543}$, o direito de recusa, a designação por meio de distribuição - como se dá com os tabelionatos de protesto, conforme parágrafo único do artigo 11 da Lei $n^{\circ}$ 8.935/94 -, a remuneração fixada por emolumentos e não por livre disposição das partes e a fiscalização e controle da atividade feitos pelo Poder Judiciário, conforme disposição do artigo 236, $\S 1^{\circ}$ da Constituição Federal, quer seja por meio da Corregedoria designada, quer seja por meio da revisão judicial dos atos $\operatorname{praticados}^{544}$.

\footnotetext{
${ }^{540}$ ASSUMPÇÃO, Letícia Franco Maculan. Função notarial e de registro: concurso público, regime jurídico e responsabilidade civil. Porto Alegre: Núria Fabris, 2011, p. 35-37.

${ }^{541}$ BRANDELLI, Leonardo. Teoria geral do direito notarial (ebook). 4 ed. São Paulo: Saraiva, 2011, p. 921.

${ }^{542}$ Ibidem, p. 926.

543 Ibidem, p. 450.

${ }^{544}$ Além dos meios ordinários de acionamento judicial, há mecanismo específico para controle da atividade, caso da suscitação de dúvida. Trata-se de ação com procedimento previsto do inciso XIII do artigo 29 da Lei $\mathrm{n}^{\mathrm{o}}$ 8.935/94 e artigo 198 da Lei $\mathrm{n}^{\circ}$ 6.015/73, que permite ao usuário questionar o ato do tabelião perante o Juízo Corregedor.
} 
Ainda assim, os mecanismos criados para garantir o preceito são mais restritos. Não há irredutibilidade de subsídios ${ }^{545}$ - a remuneração é variável conforme a utilização dos serviços - e nem vitaliciedade - não prevista na Constituição Federal de 1988. A independência do Tabelionato não tem relação direta com o orçamento e gestão públicos, mas sim provém de sua liberdade de contratação com os usuários de seus serviços e de livre gestão de seu ofício ${ }^{546}$, liberdades estas devidamente delimitadas em lei, tendo em vista a consecução do interesse público. Estas restrições, porém, não inviabilizaram o exercício de função equivalente à jurisdicional no procedimento previsto na Lei $n^{\circ} 9.514 / 97^{547}$.

Ressalte-se, a propósito, que as críticas voltadas à imparcialidade do tabelião neste rito não prosperam. A tese da suposta inexistência de terceiro intermediário imparcial com controle sobre o procedimento pelo fato de o tabelião não ter poderes para controlar a existência e montante da dívida ${ }^{548}$ são argumentos que sequer dizem respeito à imparcialidade, mas sim à competência do tabelião. Como visto, não há impedimento para que somente parte do poder jurisdicional seja transferido, sendo este o caso do tabelião no rito da Lei $n^{\circ}$ 9.514/97. No mais, no exercício de seu poder impositivo, suficiente para consolidar a propriedade em nome do credor, sua imparcialidade está preservada e sustentada na estrutura descrita acima, devendo atentar para todos os requisitos estabelecidos para tanto e não só podendo, como devendo recusar o processamento quando não atendidos, sob pena de responsabilidade ${ }^{549}$ e de revisão do ato pela via Judicial.

\footnotetext{
${ }^{545}$ BRANDELLI, Leonardo. Teoria geral do direito notarial (ebook). 4 ed. São Paulo: Saraiva, 2011, p. 450.

${ }^{546}$ Liberdade expressamente conferida pelo artigo 21 da Lei $n^{\circ} 8.935 / 94$.

547 Considerando que o escopo de atuação nesta Lei é limitado a um pequeno grupo de legitimados, a uma única espécie de crédito - os decorrentes de alienações fiduciárias de bem imóvel - e a uma pequena quantidade de atos executivos - não há, por exemplo, a pesquisa de patrimônio do executado, uma vez que o bem que garante a dívida é previamente definido -, há de se cogitar que variações no uso do modelo podem revelar a insuficiência da estrutura. Porém, na atual configuração, isso não tem ocorrido.

${ }^{548}$ FABRÍCIO, Adroaldo Furtado. A alienação fiduciária de imóveis: aspectos processuais da Lei n. 9514/97. Disponível em < http://www.fabricioadvogados.com.br/artigos/art8.htm>. Acesso em 07 jul. 2015; YOSHIKAWA, Eduardo Henrique de Oliveira. Execução extrajudicial e devido processo legal. São Paulo: Atlas, 2010, p. 40. Este último autor, em contraponto ao primeiro, registra que, em termos de imparcialidade, não há diferenças entre o agente fiduciário do Decreto-Lei $n^{\circ} 70 / 66$ e o oficial de registro de imóveis da Lei $n^{\circ}$ 9514/97, carecendo a ambos, de igual modo, a isenção necessária.

${ }^{549}$ Cf. artigo $236, \S 1^{\circ}$ da Constituição Federal e artigo 28 da Lei n ${ }^{\circ}$ 6.015/73 e artigos 22 a 24 da Lei no 8.935/94.
} 
Do exposto, pode-se concluir que a imparcialidade se impõe a todos os agentes, havendo desjudicialização de atos jurisdicionais ou não, quer seja na desjudicialização administrativa, quer seja na desjudicialização privada.

De igual modo, a manutenção do preceito é possível em todos os tipos de delegação, inclusive de forma muito similar à que hoje já é praticada, ressalva feita à desjudicialização privada de atos jurisdicionais, em que é necessária a elaboração de uma nova estrutura que permita ao agente dotado da função exercê-la com a necessária imparcialidade fora do âmbito público. Essa reformulação, porém, não impede a modalidade, desde que haja controle da atividade como um todo, desde os critérios para investidura, designação, exercício e remuneração, passando pelas possibilidades de supervisão e revisão da atividade profissional e dos atos praticados.

\subsubsection{Contraditório e ampla defesa}

No capítulo primeiro, restou assentado que, na condição de condenado, com direito material já reconhecido contra si, ao devedor executado não há outra postura defensiva possível senão atacar a execução em curso ${ }^{550}$. Diz-se, pois, que o exercício do contraditório na execução, via de regra, depende de respostas do devedor aos comandos judiciais tendentes à satisfação do título executivo ${ }^{551}$.

Estas respostas aos comandos judiciais se dão de duas formas: no próprio rito executivo ou nos meios típicos de defesa. No próprio rito executivo, o contraditório se dá em incidentes cognitivos destinados a preparar, possibilitar ou dimensionar a entrega do bem

${ }^{550}$ CRUZ E TUCCI, José Rogério. Tutela processual do direito do executado (20 anos de vigência do CPC). Revista da Ajuris, v. 21, n. 61, p. 100-120, jul. 1994, p. 103.

${ }^{551}$ CARVALHO, Milton Paulo de. Os princípios e um novo código de processo civil. In: CARNEIRO, Athos Gusmão; CALMON, Petrônio (org.). Bases científicas para um renovado direito processual. 2 ed. Salvador: Juspodivm, 2009, p. 212. 
ao exequente por meio da tutela jurisdicional executiva ${ }^{552}$, como nos casos suspensão e extinção do processo, nas alegações de fraude à execução, nas hipóteses em que se faz necessário garantir a observância do princípio do menor sacrifício ao devedor - como eventual impenhorabilidade de um bem - ou para suscitar questões cognoscíveis de ofício pelo juiz, casos dos pressupostos processuais e condições da ação ${ }^{553}$.

Para além do rito executivo, ele se verifica no incidente processual de impugnação ao cumprimento de sentença e na ação autônoma de embargos do executado ${ }^{554}$, ocasiões em que as matérias passíveis de discussão são mais amplas do que aquelas facultadas durante o próprio rito executivo e a discussão, a depender da vulnerabilidade do título executivo maior nos títulos extrajudiciais - pode avançar até a gênese do direito material controvertido $^{555}$, conformando-se o contraditório tal como nos processos ou fases de conhecimento.

Na execução desjudicializada não há de ser diferente. Qualquer hipótese de desjudicialização que se pretenda adotar no Brasil deve observar o princípio do contraditório, dando a ambas as partes oportunidades de manifestação e convencimento do agente executivo dotado de função jurisdicional, inclusive possibilitando a ambas o acionamento de um juiz ${ }^{556}$. Trata-se de direito fundamental inexpugnável, consagrado na Constituição,

552 DINAMARCO, Cândido Rangel. Instituições de Direito Processual Civil - Volume IV. 3 ed. São Paulo: Malheiros, 2009, p. 72.

${ }^{553}$ WAMBIER, Luiz Rodrigues; TALAMINI, Eduardo. Curso avançado de Processo Civil - Volume 2.13 ed. São Paulo: Editora Revista dos Tribunais, 2013, p. 178; DIDIER JUNIOR, Fredie; BRAGA, Paula Sarno; OLIVEIRA, Rafael; CUNHA, Leonardo José Carneiro da. Curso de direito processual civil - Execução Volume 5.4 ed. Salvador: Editora Juspodivm, 2012, p. 54.

${ }^{554}$ CÂMARA, Alexandre. Lições de Direito Processual Civil - Volume II. 20 ed., Rio de Janeiro: Lumen Juris, 2012, p. 157; DIDIER JUNIOR, Fredie; BRAGA, Paula Sarno; OLIVEIRA, Rafael; CUNHA, Leonardo José Carneiro da. Curso de direito processual civil - Execução - Volume 5.4 ed. Salvador: Editora Juspodivm, 2012 , p. 54.

555 JORGE, Flavio Cheim. Relação processual e contraditório nas diversas espécies de execução. In: DIDIER JR., Fredie (coord.). Execução civil: estudos em homenagem ao professor Paulo Furtado. Rio de Janeiro: Editora Lumen Juris, 2006, p. 104.

556 BATISTA SANTOS, Guilherme Luis Quaresma. Contraditório e execução. Rio de Janeiro: Lumen Juris, 2013, p. 201; DINAMARCO, Cândido Rangel. Execução civil. 8 ed. São Paulo: Malheiros, 2002, p. 325. 
com aplicação no âmbito público ou privado ${ }^{557}$ e que deve ser conciliado com a celeridade para garantir uma execução justa ${ }^{558}$.

Dentre as peculiaridades que se pode ressaltar acerca do princípio em caso de desjudicialização, há de se atentar para a hipotética desjudicialização de atos jurisdicionais. Nestes casos, como visto, o procedimento executivo criado em decorrência deve, preferencialmente, ser meramente alternativo ao judicializado, preservando-se, assim, a inafastabilidade do controle jurisdicional exercido pelo Poder Judiciário. Nestas circunstâncias, tendo em conta a conciliação entre o princípio da inafastabilidade do controle jurisdicional e o princípio do contraditório e ampla defesa, como o executado há de exercer seu contraditório?

É bem verdade que, em regra, o exercício do contraditório na execução depende de respostas do devedor aos comandos jurisdicionais tendentes à satisfação do título executivo, o que levaria a um raciocínio inicial de que o controle jurisdicional das lesões ou ameaças de lesões aos direitos do executado seria apenas eventual, quando houvesse efetiva reação do executado aos comandos.

Porém, não se pode olvidar que, em que pese ter como objetivo principal a satisfação do exequente, a jurisdição executiva, indiretamente, tutela também o executado, de ofício, independentemente de haver ou não reação aos comandos judiciais. É o que se dá, por exemplo, quando o juiz, em juízo de proporcionalidade ${ }^{559}$, busca a satisfação do credor com menor sacrifício possível ao devedor, obrigando o respeito à ordem legal bens penhoráveis, ou extingue uma execução por ausência de pressupostos ou condições da ação executiva ${ }^{560}$. E, na hipótese aqui adotada, o executado não optou pela via desjudicializada que o tutela,

\footnotetext{
${ }^{557}$ SICA, Heitor Vitor Mendonça. Perspectivas atuais da "Teoria Geral do Processo". In: CARNEIRO, Athos Gusmão; CALMON, Petrônio (org.). Bases científicas para um renovado direito processual. 2 ed. Salvador: Juspodivm, 2009, p. 73-75; MACIEL JUNIOR, João Bosco. Aplicabilidade do princípio do contraditório nas relações particulares. São Paulo: Saraiva, 2009, p. 70.

${ }^{558}$ SAMPAIO, J.M. Gonçalves. A acção executiva e a problemática das execuções injustas. 2 ed. Coimbra: Edições Almedina, 2008, p. 451.

${ }^{559}$ CARVALHO FILHO, Milton Paulo de. Aplicação do princípio da proporcionalidade à execução, à luz das leis n. 11.232/2005 e 11.382/2006. In: CARVALHO, Milton Paulo de (coord.). Direito processual civil. São Paulo: Editora Quartier Latin, 2007, p. 475.

560 YARSHELL, Flávio Luiz. Tutela jurisdicional. 2 ed. São Paulo: DPJ Editora, 2006, p. 33-34.
} 
tendo sido escolha exclusiva do exequente. Esta peculiaridade implicaria em violação à inafastabilidade do poder jurisdicional exercido pelo Poder Judiciário?

A resposta é negativa. Como visto no item oportuno, a escolha do procedimento pelo exequente decorre naturalmente da vantagem de ter seu direito reconhecido em título executivo. Assim, o curso natural da execução contempla, apenas, a satisfação do credor. Os atos de ofício que porventura beneficiem o devedor, somente o fazem indiretamente, em sede de tutela não do exequente, mas do devido processo legal. Entendimento contrário implicaria admitir atuação jurisdicional desvinculada da inércia que a caracteriza, o que não se admite por princípio. Ademais, a inexistência de prejuízo ao executado - afinal, ele é beneficiado por estas tutelas - impede a anulação de atos desta sorte.

Assim, inerte o executado, o que, diga-se, ocorre com alguma frequência ${ }^{561}$, a execução pode se consumar normalmente, sem que a parte executada atue em qualquer das oportunidades que lhe sejam conferidas e sem que isso configure qualquer nulidade.

Havendo reação, na esteira do entendimento exarado até aqui, a priori não pode haver óbices para que o executado leve a questão para discussão perante o Poder Judiciário, já que toda e qualquer lesão ou ameaça de lesão a direito deve ter caminho livre à jurisdição oficial. Como a submissão do executado ao procedimento desjudicializado se deve, até o momento em que reage, apenas e tão-somente à vontade do exequente, que optou pelo procedimento alternativo quando do ajuizamento da ação, não é lícita sua imposição à parte adversa quando é dela o direito diretamente tutelado.

Isto não impede que, querendo e havendo delegação de competências ao agente executivo para tanto, o executado opte por estabelecer a discussão no próprio âmbito

\footnotetext{
${ }^{561}$ Heitor Vitor Mendonça registra o baixo índice de oportunidades em que os devedores se defendem nos processos de execução físcal, cerca de 10,9\% dos casos, somando-se as hipóteses de exceção de préexecutividade e embargos à execução (Perfis do contraditório e da ampla defesa na execução físcal federal. Gestão e jurisdição: o caso da execução fiscal da União - Série “Diálogos para o desenvolvimento” v.9. CUNHA, Alexandre dos Santos; ALVES DA SILVA, Paulo Eduardo (coord.). Brasília: IPEA, p.209-222, 2013, passim).
} 
desjudicializado. Nesta hipótese, a exemplo do que se dá com o exequente, tendo o executado optado pela via desjudicializada, é obstado o recurso direto ao Poder Judiciário.

Logo, qualquer que seja o modelo adotado, dentro dos limites da "cognição possível" oferecida pela execução ${ }^{562}$, ou seja, sem que a defesa do executado configure "óbice injustificável” à prática de atos executórios, não deve haver restrições à garantia do contraditório $^{563}$.

A técnica utilizada para tanto é de menor relevância, se interna ou externa ao rito executivo, se examinada pelo juiz ou pelo agente executivo. O importante é haver meios que ofereçam às partes - e, precisamente, ao executado - a possibilidade de provocarem cognição e influenciarem o deslinde do processo executivo, deduzindo toda e qualquer matéria que o ordenamento entender passível de questionamentos na execução ${ }^{564}$.

Sem prejuízo desta liberdade quanto à técnica, do Novo Código de Processo Civil pode-se extrair os requisitos mínimos escolhidos pelo legislador para que o executado exerça o contraditório com a devida amplitude e sem configurar óbice injustificável ao processo.

Os procedimentos ordinários de execução por quantia contemplados pela mencionada codificação, conferem possibilidade ao executado de, tão logo cientificado do processo, apresentar uma defesa em que possa atacar amplamente a execução movida contra si, com matérias mais ou menos restritas a depender do tipo de título executivo que embasa a execução. Em qualquer caso, este tipo de via defensiva independe de atos de constrição ou garantia ao Juízo e, em regra, não suspende a execução.

\footnotetext{
562 Milton Paulo de Carvalho Filho, na esteira da doutrina de Leonardo Carneiro da Cunha, classifica como "rarefeita" a cognição limitada praticada na execução (Aplicação do princípio da proporcionalidade à execução, à luz das leis n. 11.232/2005 e 11.382/2006. In: CARVALHO, Milton Paulo de (coord.). Direito processual civil. São Paulo: Editora Quartier Latin, 2007, p. 481).

${ }_{563}$ BEDAQUE, Jose Roberto dos Santos. Cognição e decisões do juiz no processo executivo. In: FUX, Luiz; NERY JUNIOR, Nelson; WAMBIER, Tereza Arruda Alvim (coord.). Processo e constituição: estudos em homenagem ao professor José Carlos Barbosa Moreira. São Paulo: Editora Revista dos Tribunais, 2006, p. 378.

${ }^{564}$ Ibidem, p. 377.
} 
As matérias cujas arguições se fizerem necessárias após o prazo deste meio principal de defesa, notadamente questões concernentes à validade e à adequação da penhora, à avaliação e aos atos executivos subsequentes, devem ter meios que possibilitem suas discussões, ainda que seja uma provocação por simples petição.

No contexto proposto pelo ordenamento, parece exigência indispensável que existam meios específicos e inerentes à demanda executiva para o exercício do direito defesa, não bastando o direito de acesso ao Judiciário por meio de ação autônoma. Em que pese existirem estudos no sentido de confluência entre o direito de defesa e o direito de ação ${ }^{565}$, o direito nacional ainda segmenta estas categorias.

Tomando por base estes parâmetros fixados e a regra geral de que as partes devem ter à disposição meios de provocar cognição sempre que se fizer necessário e o questionamento não gerar óbice injustificável ao processo, há de se reconhecer que este aspecto é falho nos procedimentos desjudicializados do Decreto-Lei $n^{\circ} 70 / 66$ e Lei $n^{\circ}$ 9.514/97.

Quanto ao Decreto-Lei $n^{\circ} 70 / 66$, assiste razão aos opositores do procedimento quando apontam a falha na garantia de contraditório ${ }^{566}$ ante a ausência de oportunidades de defesa ao devedor antes da alienação de seu imóvel, cabendo-lhe a única alternativa de pagar o débito atrasado e apenas o potencial acesso ao Poder Judiciário mediante ação autônoma, ou em vias de imissão na posse, sem qualquer meio específico para tanto ${ }^{567}$. Trata-se, de

\footnotetext{
${ }^{565}$ Neste sentido, SICA, Heitor Vitor Mendonça. O direito de defesa no Processo Civil brasileiro. São Paulo: Atlas, 2011.

566 MARINONI, Luiz Guilherme. O direito à efetividade da tutela jurisdicional na perspectiva da teoria dos direitos fundamentais. Revista de Direito Processual Civil. Curitiba: Gênesis, abr.-jun., 2003, p. 318; BECKER, L.A. Contratos bancários: execuções especiais. São Paulo: Malheiros, 2002, p. 315.

567 YOSHIKAWA, Eduardo Henrique de Oliveira. Execução extrajudicial e devido processo legal. São Paulo: Atlas, 2010, p. 104; RIBEIRO, Flávia Pereira. A desjudicialização da execução civil. São Paulo: Saraiva, 2013, p. 51; DENARDI, Volnei Luiz. Execuções judicial e extrajudicial no sistema financeiro da habitação. São Paulo: Editora Revista dos Tribunais, 2009, p. 124; GRINOVER, Ada Pellegrini. Novas tendências do direito processual de acordo com a Constituição de 1988. Rio de Janeiro: Forense Universitária, 1990, p. 200.
} 
fato, como ali consignado, de procedimento unilateral, ante a inidoneidade - ou, no caso, inexistência - dos meios de defesa para exercício do contraditório ${ }^{568}$.

Situação similar se passa com o contraditório da Lei $\mathrm{n}^{\circ}$ 9.514/97, com nova exacerbação da unilateralidade, já que aqui também carecem oportunidades de defesa ao devedor ${ }^{569}$, sendo a ele facultado apenas o pagamento da quantia devida. A faculdade de provocar cognição perante órgão investido de poder de decisão se dá por meio da arbitragem - apenas se prevista em contrato ${ }^{570}$ - ou pelo acionamento do judiciário em momentos oportunos $^{571}$, mas, novamente, sem qualquer via específica para tanto ${ }^{572}$.

\subsubsection{Razoável duração do processo}

Como visto, a razoável duração do processo se ancora em dois valores básicos, que devem atuar sempre em equilíbrio: a celeridade e a segurança jurídica ${ }^{573}$. Não há de se buscar um processo seguro, porém demasiadamente lento ${ }^{574}$, tampouco um processo rápido "a qualquer preço" ${ }^{\circ 75}$, incapaz de garantir um mínimo de segurança jurídica ${ }^{576}$.

O contexto nacional, apurado no primeiro capítulo, fornece elementos para que se identifique um problema de lentidão, reflexo de uma estrutura sobrecarregada tanto no

${ }^{568}$ BECKER, L.A. Contratos bancários: execuções especiais. São Paulo: Malheiros, 2002, p. 320.

${ }^{569}$ FABRÍCIO, Adroaldo Furtado. A alienação fiduciária de imóveis: aspectos processuais da Lei $n$. 9514/97. Disponível em < http://www.fabricioadvogados.com.br/artigos/art8.htm>. Acesso em 07 jul. 2015; BECKER, L.A. Contratos bancários: execuções especiais. São Paulo: Malheiros, 2002, p. 320.

${ }^{570}$ SAAD, Renan Miguel. A alienação fiduciária sobre bens imóveis. Rio de Janeiro: Renovar, 2001, p. 255.

571 Cândido Rangel Dinamarco identifica dois momentos essenciais para a provocação do controle jurisdicional, quais sejam, no início ou durante o trâmite do procedimento, para ilidir as exigências do credor ou a regularidade do procedimento, ou após a venda em leilão, para discussão do valor pelo qual se deu (DINAMARCO, Cândido Rangel. Fundamentos do processo civil moderno - Tomo II. 5 ed. São Paulo: Malheiros, 2002, p. 1280).

572 TERRA, Marcelo. Alienação fiduciária de imóvel em garantia (lei $n^{\circ}$ 9.514/97, primeiras linhas). Porto Alegre: Sergio Antonio Fabris Editor, 1998, p. 54.

573 BEDAQUE, José Roberto dos Santos. Efetividade do processo e técnica processual. 3 ed. São Paulo: Malheiros, 2010, p. 49.

${ }^{574}$ MARINONI, Luiz Guilherme. O direito à efetividade da tutela jurisdicional na perspectiva da teoria dos direitos fundamentais. Revista de Direito Processual Civil. Curitiba: Gênesis, 2003, p. 305.

575 BARBOSA MOREIRA, José Carlos. O futuro da justiça: alguns mitos. Revista da Academia Brasileira de Letras Jurídicas, Rio de Janeiro, v. 17, jan.-dez. 2001, p. 157.

576 BEDAQUE, José Roberto dos Santos. Efetividade do processo e técnica processual. 3 ed. São Paulo: Malheiros, 2010, p. 49. 
aspecto orçamentário - trata-se de uma atividade deficitária - quanto no aspecto estrutural apesar de quase a totalidade dos gastos ser voltada para expensas com pessoal, ainda assim há enorme dificuldade para que estes gastos sejam revertidos em produtividade suficiente para atender a demanda de processos.

Diante deste contexto explanado, seria possível afirmar a desjudicialização como um mecanismo de aceleração capaz de contribuir de forma significativa para a melhoria do quadro?

A abordagem trazida até aqui evidenciou que a ideia de desjudicialização é bastante abrangente e flexível. Trata-se de técnica extrajudicial de aceleração do processo, cuja aplicação não respeita um modelo estanque, sendo possíveis diversas configurações procedimentais com a utilização do recurso.

Dentre as alternativas analisadas, pode-se conceber desjudicializações administrativas ou privadas - quando os atos são transferidos para o próprio Poder Público ou para a iniciativa privada, respectivamente -, incidentais ou preponderantes - quando há apenas alguns atos desjudicializados em meio a um procedimento judicializado, no primeiro caso, e quando há maioria de atos desjudicializados, no segundo - obrigatórias ou meramente alternativas - quando não há alternativa à parte requerente senão ser submetida ao procedimento desjudicializado ou quando pode optar por esta ou pela via judicializada, respectivamente - e com deslocamento de poder jurisdicional ou não - a depender se há ou não transferência de atos decisórios ou impositivos de direito.

Esta variedade permite a projeção de diversas possibilidades de desjudicialização com vistas à aceleração do processo, devendo a sua utilização se adaptar conforme as necessidades e limitações do contexto em que se inserem.

Mas, de modo geral, as melhorias que podem ser obtidas com a desjudicialização decorrem de três vertentes principais, todas intimamente interligadas, quais sejam, a possibilidade de especialização, a desvinculação das administrações orçamentária e de pessoal e a redução no consumo de tempo e recursos do Poder Judiciário.

A primeira vertente, possibilidade de especialização, não é uma característica exclusiva da desjudicialização - é possível que se promova especialização dentro do próprio Judiciário, como, por exemplo, com a criação de varas com competências mais restritas mas encontra neste mecanismo uma oportunidade quase natural. Considerando que a 
desjudicialização desloca um determinado ato ou grupo de atos para fora do Poder Judiciário, a seleção destes atos tende a ser feita com base em determinado propósito, como a agilização na alienação de bens penhorados ou da execução de créditos voltados à habitação.

Uma vez que um determinado agente tenha um propósito destacado do objetivo geral e que a sua funcionalidade esteja atrelada à efetividade e bom desempenho de seu mister, é esperado que organize sua atividade de forma a atender aquele tipo específico de demanda à qual é submetido. Este benefício pode ser estimulado tanto na esfera pública, em vias de desjudicialização administrativa, com, por exemplo, a criação de órgãos e pessoas jurídicas de direito público com a finalidade específica que for necessária, quanto na esfera privada, com a desjudicialização de atos para pessoas capazes de se estruturarem e adequarem para a atividade delegada.

A segunda das vertentes, administrações orçamentária e de pessoal, guarda íntima relação com a primeira. Consiste na possibilidade de a desjudicialização, qualquer que seja, permitir segmentar do regramento geral do Judiciário a gestão de pessoas e recursos financeiros da atividade destacada.

Assim, é que, por exemplo, na desjudicialização incidental hoje praticada com os leiloeiros, há critérios e métodos próprios para investidura, seleção e custeio da atividade, independentes daqueles praticados com os servidores do Poder Judiciário. Além disso, cada leiloeiro goza de autonomia para estruturar sua atividade, contratando materiais e mão de obra próprios e adequados às suas necessidades e possibilidades, sem qualquer dependência direta do orçamento do Judiciário.

O mesmo se dá nos procedimentos preponderantemente desjudicializados, destacados no capítulo segundo, os quais são todos geridos e custeados de forma independente, sem necessidade de intervenção do Poder Judiciário.

Estes exemplos evidenciam que na desjudicialização privada este aspecto é ainda mais relevante, haja vista a indiscutível maior mobilidade de uma pessoa de direito privado para contratação de pessoal e serviços, estabelecimento de planos de gestão, com controle de metas, análise e investimento em infraestrutura e otimização de produtividade.

Tome-se por hipótese uma reformulação na organização do Poder Judiciário com vistas à resolução da sobrecarga causada pela execução, acima identificada. Assumindo-se que essa reforma tenha por pressupostos a criação de varas especializadas para execução de 
pagar quantia, com corpos funcionais próprios e destinações orçamentárias específicas algo que poderia ser feito de forma análoga com uma desjudicialização -, a mudança, inevitavelmente, ou imporia um significativo acréscimo orçamentário- que, como visto, já é deficitário - ou demandaria deslocamentos de recursos e pessoal, com prejuízo aos demais processos que demandam tutela jurisdicional Judiciária.

Neste mesmo cenário, a tentativa de solução por meio de uma desjudicialização de parâmetros similares, permitiria a elaboração de formas de custeio e gestão de recursos independentes daquelas praticadas no Judiciário, com criação de corpo funcional específico, com funções e remunerações voltadas para a atividade destacada, custeadas da forma que se revelar mais pertinente conforme o caso concreto.

Finalmente, e talvez este seja o aspecto mais relevante da desjudicialização, é a redução na alocação e utilização dos recursos orçamentários, aqui incluídos os gastos com pessoal e aparelhamento dos cartórios e varas judiciais, destinados pelo Judiciário para administrar e praticar a execução.

Sua relevância se explica ante o diagnóstico do capítulo primeiro, de um Poder Judiciário deficitário, com quase $90 \%$ de seu orçamento destinado a gastos com pessoal e que convive com crescentes quantidades de processos e taxas de congestionamento de quase todas as categorias de análise, cuja desoneração, por si só, já é motivo bastante para que a desjudicialização seja cogitada como técnica de aceleração a ser empregada. Este último argumento, inclusive, é utilizado por parte da doutrina para justificar o emprego da técnica, acima de qualquer empecilho ${ }^{577}$.

${ }^{577}$ RIBEIRO, Flávia Pereira. A desjudicialização da execução civil. São Paulo: Saraiva, 2013, p. 32. 
Livrando-se do encargo de alguns atos executivos, o Judiciário pode realocar os recursos poupados em outros segmentos ${ }^{578}$, priorizando, por exemplo, a solução dos processos de conhecimento e, ao menos em tese, reduzir a crise que lhe afeta ${ }^{579}$.

Todos os três aspectos podem, concretamente, ser obtidos a partir de uma iniciativa de desjudicialização, sendo a celeridade uma possível melhoria deles decorrente. Diz-se possível porque a ligação entre estes aspectos e a efetiva aceleração do processo passa por um diagnóstico preciso do problema enfrentado ${ }^{580}$, seguido de planejamento e estudo aprofundados sobre a viabilidade não só jurídica, mas também econômico-financeira da desjudicialização pretendida e, finalmente, uma implantação conforme o planejamento, etapas que, se falhas, podem comprometer o ideal almejado.

Cite-se como exemplo a experiência portuguesa, cuja iniciativa lá adotada, como visto, num primeiro momento apresentou uma série de problemas decorrentes da falta de estrutura para acomodar as mudanças implementadas pelo Decreto-Lei $n^{\circ}$ 38/2003, notadamente no que dizia respeito ao preparo e formação dos solicitadores para a função de agentes executivos ${ }^{581}$, obrigando uma nova reforma, com a abertura de possibilidade aos advogados, desde que habilitados, para o exercício da função ${ }^{582}$. Este problema inicial contribuiu para uma redução no número de processos executivos encerrados por ano entre 2005 e 2009, quando entrou em vigor a segunda reforma: de 220.988 no primeiro ano, para

${ }^{578}$ MANCUSO, Rodolfo de Camargo. A resolução dos conflitos e a função judicial no contemporâneo Estado de Direito. 2 ed. São Paulo: Editora Revista dos Tribunais, 2014, p. 170; HELENA, Eber Zoehler Santa. O fenômeno da desjudicialização. Jus Navigandi, Teresina, ano 11, n. 922, 11 jan. 2006. Disponível em <http://jus.com.br/artigos/7818>. Acesso em: 30 abr. 2014.

${ }^{579}$ FIGUEIRA JÚNIOR, Joel Dias. Execução simplificada e a desjudicialização do processo civil. In: ALVIM NETTO, José Manoel de Arruda; et al (coord.). Execução civil e temas afins do CPC/1973 ao Novo CPC: estudos em homenagem ao professor Araken de Assis. São Paulo: Editora Revista dos Tribunais, 2014, p. 600. ${ }^{580}$ HASSON, Roland; BACK, Hermínio. Crise na prestação jurisdicional: uma solução radical. In: GUNTHER, Luiz Eduardo (coord.). Jurisdição: crise, efetividade e plenitude institucional. Curitiba: Juruá, 2009, p. 666; SCHENK, Leonardo Faria. Breve relato histórico das reformas processuais na Itália. Um problema constate: a lentidão dos processos cíveis. Revista eletrônica de direito processual, Rio de Janeiro, ano 2, vol. II, jan.-dez. 2008, p. 199.

581 ALEMÃO, Ivan. A reforma da execução em Portugal. Disponível em <http://jus.com.br/revista/texto/10000/reforma-da-execucao-em-portugal>. Acesso em 09 out. 2012.

582 BATISTA SANTOS, Guilherme Luis Quaresma. Contraditório e execução. Rio de Janeiro: Lumen Juris, 2013, p. 194-196. 
197.759 no último ano deste período. Desde então e até o início de 2013, houve aumento progressivo deste número, constando o último registro de 400.925 processos findos ${ }^{583}$.

Assim, ainda que não haja uma garantia absoluta de que se obtenha com a desjudicialização toda a celeridade pretendida, é certo que a boa conjugação dos elementos pode render frutos positivos à razoável duração do processo no Brasil. Rememore-se que Barbosa Moreira, já há mais de dez anos, indicava como fatores relevantes para a morosidade do processo brasileiro a escassez de órgãos judiciais em relação à população crescente, a irracional divisão do território em comarcas, sem comprometimento com o volume de trabalho, a má organização do trabalho e a insuficiente utilização da tecnologia, todos culminando com baixos índices de produtividade ${ }^{584}$. Confirmado o diagnóstico, a desjudicialização desponta como mecanismo que congrega todos os aspectos necessários para a solução pontual de cada um destes problemas elencados, pendentes planejamento e execução conforme para que se colham frutos desta iniciativa.

Em se tratando de técnica de aceleração, não se pode olvidar de seu contrapeso, a segurança jurídica. Há de se resguardar os limites de segurança desta técnica, os quais, em regra, em nada diferem dos limites impostos à execução judicial. Na medida em que, como visto, é possível se projetar um sistema desjudicializado com parâmetros praticamente idênticos aos hoje praticados pelo sistema judicializado, há de se respeitar os mesmos limites naturais e políticos ${ }^{585}$ tanto na execução judicializada quanto na desjudicializada, bem como o devido processo legal e os direitos constitucionais que dele decorrem ${ }^{586}$.

\footnotetext{
583 Dados da Direção Geral da Política de Justiça, disponível em <http://www.sig.dgpj.mj.pt/DataVisualization/DataVisualization_Movimento_AccoesExecutivas.html>, Acesso 30 nov. 2015.

${ }^{584}$ BARBOSA MOREIRA, José Carlos. O futuro da justiça: alguns mitos. Revista da Academia Brasileira de Letras Jurídicas, Rio de Janeiro, v. 17, jan.-dez. 2001, p. 156.

585 Os termos fazem referência à doutrina de Cândido Rangel Dinamarco, que define como limite natural à execução a impossibilidade de se acessar no patrimônio do executado o objeto titularizado pelo exequente e como limites políticos os direitos de personalidade, o mínimo patrimonial existencial - e, por associação, o mínimo sacrifício ao patrimônio do devedor - e o interesse público (Execução civil. 8 ed. São Paulo: Malheiros, 2002, p. 308-323).

586 DANTAS NETO, Renato de Magalhães. Novo CPC e prioridade no uso dos meios eletrônicos: mais celeridade, mais tecnologia, mais justiça? In: DIDIER JUNIOR, Fredie; ADONIAS, Antonio (coord.). Projeto do novo código de processo civil - $2^{a}$ série. Salvador: Editora Juspodivm, 2012, p. 627.
} 
A principal ressalva a ser feita é quanto a desjudicialização privada de atos jurisdicionais, ocasião em que a repetição da mesma estrutura hoje em voga, como visto, principalmente em termos de imparcialidade do agente executivo, não é possível. Neste contexto, há de se atentar para que a reestruturação permita e exija, de fato, o mesmo respeito aos limites impostos à execução judicializada, inclusive com a previsão de mecanismos para que o executado se defenda e para que a atividade do agente privado seja constantemente fiscalizada, coibindo práticas abusivas.

Finalmente, não se descarta uma iniciativa de desjudicialização em que se opte por tolher parte da segurança jurídica hoje existente, abolindo alguns dos mecanismos de garantia supracitados, como a vitaliciedade do agente executivo para o qual são transferidos atos de natureza jurisdicional. Há de se ter em mente que, enquanto técnica abrangente e flexível, são possíveis diversas configurações para o procedimento, de modo que a política legislativa influi diretamente na concepção empregada.

Nesta hipótese, porém, a ponderação entre os direitos e garantias afetados pela desjudicialização somente pode ser feita diante de uma proposta concreta, a reforçar a extrema relevância da etapa legislativa da desjudicialização, momento em que deve haver intensa participação da comunidade jurídica na fixação de seus parâmetros.

\subsection{Elementos para um modelo de execução desjudicializada}

Até aqui, a abordagem teve escopo geral e abstrato, levando em conta a desjudicialização como um todo e suas diversas possibilidades de configuração, de modo a avaliar se e em que hipóteses a técnica esbarra nos principais consectários do devido processo legal.

Nas linhas seguintes, buscaremos projetar um modelo desjudicializado de execução por quantia certa que possa atender o quadro de morosidade da execução por quantia brasileira, apontando seus principais elementos, tais como a espécie de desjudicialização mais conveniente, os agentes responsáveis pela prática, o papel do juiz, o controle da atividade e os principais aspectos referentes ao procedimento. 


\subsubsection{Que desjudicialização adotar?}

A primeira etapa para responder à indagação é identificar qual o problema que se busca combater com a desjudicialização.

Quando se desenvolveu, no capítulo primeiro, o tópico sobre a atual crise do Poder Judiciário, chegou-se à conclusão de que este Poder, de modo geral, é deficitário, dispendendo quase todo o seu orçamento com recursos humanos. Além disso, há crescimentos gerais no número de processos que anualmente tramita no Judiciário e nas taxas de congestionamento.

As execuções fundadas em títulos executivos extrajudiciais não fiscais e em títulos judiciais não criminais, categorias em que se incluem as execuções por quantia aqui tratadas, constituem grupos com crescimento quantitativo progressivo e taxas de congestionamento sempre acima da taxa geral do Poder Judiciário.

Quanto à tramitação nos gabinetes e cartórios judiciais, a execução por quantia tem alta concentração nestes últimos, com raras e apenas incidentais análises dos autos pelos juízes e seus assessores diretos nos gabinetes judiciais. Mesmo quando um ato de teor decisório é exigido, muitas vezes os cuidados de análise, valoração, deliberação e até mesmo minuta da decisão, ficam a cargo do cartório.

Neste cenário, como não poderia deixar de ser, é no cartório que se concentram os principais pontos de congestionamento da execução por quantia. No procedimento hipotético utilizado como parâmetro de aferição, somente em filas de trabalho, ou seja, nas ditas “etapas mortas”, em que nada é feito com o processo, à espera da prática do ato subsequente, foram computados cerca de 177 dias.

Tudo a confirmar que, de fato, há uma crise no Poder Judiciário e que a execução por quantia é um de seus elementos essenciais, principalmente em termos de congestionamento de processos e consumo da estrutura disponível, especialmente no que concerne aos cartórios judiciais.

Diante deste diagnóstico, o primeiro parâmetro que se pode extrair para fins de definição de um modelo executivo desjudicializado é o de que, ao menos numa primeira reforma, não é necessária a desjudicialização de atos jurisdicionais, mas, apenas e tãosomente, a desjudicialização de atos não-jurisdicionais. 
Se é certo que os cartórios judiciais, de modo geral, têm influência sobre o conteúdo, a forma e o tempo da tutela jurisdicional ${ }^{587}$, na execução por quantia essa importância é notável, uma vez que demanda poucas intervenções do juiz. Em essência, ela se dá nas ordens de pagamento, nas constrições e expropriações de bens e nos incidentes cognitivos, em geral quando o executado provoca o contraditório. Ainda assim, boa parte destes atos é precedida de análise, deliberação e minuta por profissionais atuantes no próprio cartório, nos denominados "despachos em preto", de larga utilização.

Soma-se a isso o fato de que a desjudicialização de atos jurisdicionais é muito mais complexa, não só sob o ponto de vista jurídico, como também pela ótica social.

Sob o escopo jurídico, viu-se que as garantias de monopólio, inafastabilidade, imparcialidade e naturalidade são todas elaboradas e dedicadas à atuação do detentor de função jurisdicional, atingindo os demais órgãos e agentes apenas de forma reflexa. Neste sentido, readequar estas garantias e até mesmo elaborar novos regramentos quando necessário - caso, por exemplo, da reestruturação que demandaria eventual desjudicialização privada de atos jurisdicionais - é tarefa muito mais complexa na desjudicialização de atos jurisdicionais do que na de atos não jurisdicionais, o que pode culminar com um indesejado quadro de insegurança jurídica.

De igual modo, a aceitação da mudança pela ciência jurídica nacional tende a enfrentar maiores dificuldades, vide todos os procedimentos mencionados neste trabalho que contam com desjudicialização do poder de decidir e impor decisões, casos da arbitragem, do Decreto-Lei $n^{\circ} 70 / 66$, da Lei $n^{\circ} 9.514 / 97$ e até mesmo os projetos de desjudicialização da execução fiscal, os quais tiveram e têm suas constitucionalidades constantemente questionadas.

Sob a ótica social, o raciocínio percorre o mesmo caminho. Se a permeabilidade inicial a agentes externos ao Judiciário com poderes de decisão e imposição tende a ser baixa

${ }^{587}$ SILVA, Paulo Eduardo Alves da. Gerenciamento de processos judiciais. São Paulo: Saraiva, 2010, p. 64. 
no âmbito da ciência jurídica, consequentemente a utilização desta via tende a ser pouco usual entre os operadores do direito e a população que por eles é assistida ${ }^{588}$. Tome-se por exemplo a arbitragem, via mais democrática dentre as supracitadas, haja vista que qualquer pessoa, teoricamente, poderia acessá-la. Pesquisa feita em seis das maiores câmaras arbitrais brasileiras indicou que, no ano de 2013, um total de 188 casos foram iniciados por esta via ${ }^{589}$. O número representa um expressivo aumento de $47 \%$ em comparação com o mesmo dado em 2010, porém ainda é inexpressivo diante dos números do Poder Judiciário ${ }^{590}$. A melhoria de redução no consumo de tempo e recursos do Poder Judiciário com a concentração de processos na via alternativa não foi obtida nos cerca de dezessete anos de vigência da Lei de Arbitragem, a indicar que iniciativa semelhante para fins de execução pode tomar caminho parecido, o que pode ser contornado ao se desjudicializar apenas atos não jurisdicionais, dado o menor impacto de se afastar o processo do cartório judicial, apenas, e não do juiz, principal símbolo do senso coletivo de justiça.

Admitindo-se, pois, a desjudicialização de atos não jurisdicionais, há de se estabelecer que a proposta envolve uma ampla desjudicialização deste tipo de ato. Propõese a criação de um modelo processual preponderantemente desjudicializado, em que, afora os atos jurisdicionais, todos os demais poderiam ser praticados fora do Judiciário. Trata-se de uma ampliação das desjudicializações incidentais já praticadas e apontadas quando da análise dos procedimentos de execução por quantia do Código de Processo Civil.

Não se nega, com isso, que um aumento pontual das desjudicializações incidentais poderia ser funcional. Porém, a utilização desta via demandaria um diagnóstico minucioso - hoje inexistente - dos atos praticados pelos cartórios, de modo a identificar quais demandam mais tempo e esforço e que poderiam ser objeto de desjudicialização. A adoção

\footnotetext{
${ }^{588}$ GUERRERO, Luis Fernando. Alternative dispute resolution e adequação ao momento histórico - a questão do acesso à justiça. In: CARNEIRO, Athos Gusmão; CALMON, Petrônio (org.). Bases científicas para um renovado direito processual. 2 ed. Salvador: Juspodivm, 2009, p. 269.

589 LEMES, Selma. Análise da Pesquisa Arbitragem em Números de 2010 a 2013. Disponível em: < http://selmalemes.adv.br/artigos/An\%C3\%A1lise\%20da\%20Pesquisa\%20Arbitragem\%20em\%20N\%C3\%B Ameros\%20-2010-2013.pdf >. Acesso em 05 dez. 2015.

${ }^{590}$ ALMEIDA, João Alberto de. Desjudicialização: a relação entre a arbitragem e os serviços notariais e registrais. Revista da Faculdade de Direito da Universidade Federal de Minas Gerais, Belo Horizonte, v. 59, junho-dezembro 2011, p. 114.
} 
de uma ampla desjudicialização supre esta carência, já que todo o corpo funcional do Poder Judiciário, de modo geral, seria beneficiado.

Esta via preponderantemente desjudicializada quanto aos atos não jurisdicionais, por medida de cautela, deve ser alternativa à judicial. Isto porque obrigar, desde o início da proposta, a utilização de uma via desjudicializada, expõe a iniciativa a riscos desnecessários, tais como as dificuldades de preparo e formação dos agentes registradas em Portugal, conforme relatado acima.

Viu-se que não há empecilhos para que o modelo venha a se tornar obrigatório caso verificado o seu sucesso, já que a inafastabilidade de controle jurisdicional não afeta os atos não jurisdicionais e, no modelo proposto, a jurisdição estará preservada com o juiz. Todavia, o teste prévio de funcionalidade dos cartórios desjudicializados, ainda como forma alternativa de movimentação processual, preservando-se a estrutura judicializada hoje existente, é etapa de indispensável razoabilidade para este avanço.

Finalmente, esta desjudicialização alternativa, preponderante, de atos não jurisdicionais, há de ser privada. A desjudicialização administrativa, ao menos para créditos de natureza não fiscal, é inviável ante o contexto apresentado.

A crise identificada, em última análise, diz respeito à insuficiência e à má gestão de recursos do Poder Judiciário para lidar com a demanda de processos, crise esta que não lhe é exclusiva, mas sim parte de um problema maior, que diz respeito ao Estado como um todo $^{591}$ e sua frequente dificuldade em custear e administrar a contento os serviços que presta.

Dada a dimensão do problema, há de se reconhecer que defender uma desjudicialização administrativa, em geral, não traz uma perspectiva melhor do que defender

\footnotetext{
${ }^{591}$ PASSOS, J. J. Calmon de. A crise do poder judiciário e as reformas instrumentais: avanços e retrocessos. Revista Eletrônica sobre a Reforma do Estado, n. 3, set.-nov. 2005, Salvador, Disponível em <http://www.direitodoestado.com/revista/RERE-3-SETEMBRO-2005-CALMON\%20DE\%20PASSOS.pdf〉. Acesso em 15 nov. 2014, p. 1; GRECO, Leonardo. Novas perspectivas da efetividade e do garantismo processual. In: MITIDIERO, Daniel; AMARAL, Guilherme Rizzo (coord.). Processo Civil: estudos em homenagem ao Professor Doutor Carlos Alberto Alvaro de Oliveira. São Paulo: Editora Atlas, 2012, p. 281.
} 
uma técnica extraprocessual de aceleração do processo, tal como investimentos na estrutura já pronta e estabelecida do Poder Judiciário.

Se o propósito é a utilização de um mecanismo extrajudicial de aceleração, a aposta na desjudicialização privada se revela mais promissora, tanto pela maior mobilidade de uma pessoa de direito privado para contratação de pessoal e serviços, estabelecimento de planos de gestão, controle de metas com os respectivos ajustes, análise e investimento em infraestrutura com vistas à otimização de produtividade, como também na maior desoneração da estrutura não só do Judiciário, mas do Estado como um todo. Além disso, na iniciativa privada, há também os efeitos de ordem socioeconômica, com estímulo à circulação de renda e potencial ingresso de receitas nos cofres públicos ${ }^{592}$, o que, se não é imprescindível, depõe favoravelmente ao modelo.

Logo, a proposta desenvolvida adiante, idealizada a partir do diagnóstico efetuado acerca da morosidade processual no Brasil, pressupõe uma desjudicialização preponderante dos atos não jurisdicionais, capaz de proporcionar ao exequente um procedimento alternativo de execução por quantia, cuja tramitação será majoritariamente perante agentes privados, preservada a competência do juiz nos atos que demandarem a prática de atos de decisão e de imposição de decisões. Seus aspectos essenciais serão traçados no próximo item.

\subsubsection{Aspectos essenciais}

O modelo proposto a seguir tem por objetivo um mínimo impacto na segurança jurídica da execução por quantia, sem prejuízo de se almejar as melhorias supracitadas com a desjudicialização de acordo com os parâmetros fixados.

Para tanto, a ideia é a criação de uma espécie de "cartório privado", com o aproveitamento da estrutura já existente junto aos tabelionatos de protesto. No caso, o tabelião titular assumiria função análoga à que hoje é exercida pelos escrivães judiciários,

${ }^{592}$ FIGUEIRA JÚNIOR, Joel Dias. Execução simplificada e a desjudicialização do processo civil. In: ALVIM NETTO, José Manoel de Arruda; et al (coord.). Execução civil e temas afins do CPC/1973 ao Novo CPC: estudos em homenagem ao professor Araken de Assis. São Paulo: Editora Revista dos Tribunais, 2014, p. 600. 
porém contando com a prerrogativa de gestão privada dos serviços que presta - que lhe é garantida pelo artigo 236 da Constituição Federal - para consecução dos objetivos.

Os atos jurisdicionais e o controle da atividade permaneceriam sob encargo do Poder Judiciário, a critério do juiz, alterando-se apenas o que se revelar estritamente necessário para viabilização da atividade.

Para que se compreenda os exatos termos da proposta, inicialmente serão analisados os agentes protagonistas deste procedimento para que, em seguida, se apresente, em essência, o procedimento a ser seguido.

\subsubsection{Agentes envolvidos na execução}

\subsection{Tabelião de protesto}

A figura do tabelião já foi tratada neste trabalho quando se enfrentou a viabilidade da desjudicialização privada ante a necessidade de imparcialidade do agente encarregado da execução. Em linhas gerais, restou assentado que sua atividade, disciplinada a partir do artigo 236 da Constituição Federal, é exercida em regime privado, a despeito do exercício de função pública - e daí se falar em desjudicialização privada.

Trata-se de profissional que tem dever de imparcialidade ${ }^{593}$, dever este promovido por mecanismos como a investidura por meio de concurso público ${ }^{594}$, a inamovibilidade ${ }^{595}$, o tabelião natural, no caso dos tabelionatos de protesto, conferido pela designação do profissional por meio de distribuição - conforme parágrafo único do artigo 11 da Lei $\mathrm{n}^{\circ}$ 8.935/94 - e a remuneração fixada por emolumentos. O controle da atividade é feito pelo Poder Judiciário, conforme disposição do artigo 236, $§ 1^{\circ}$ da Constituição Federal, quer seja

\footnotetext{
${ }^{593}$ BRANDELLI, Leonardo. Teoria geral do direito notarial (ebook). 4 ed. São Paulo: Saraiva, 2011, p. 921.

594 Todas as etapas do concurso público para provimento de tabelionatos, desde a abertura de vagas até a classificação final, são de responsabilidade do Poder Judiciário (CENEVIVA, Walter. Lei dos notários e dos registradores comentada (Lei n. 8935/94). 6 ed. São Paulo: Saraiva, 2007, p. 154).

${ }^{595}$ BRANDELLI, Leonardo. Teoria geral do direito notarial (ebook). 4 ed. São Paulo: Saraiva, 2011, p. 450.
} 
por meio da Corregedoria designada, quer seja por meio da revisão judicial dos atos praticados.

$\mathrm{O}$ artigo $5^{\circ}$ da Lei $n^{\circ} 8.935 / 94$ prevê três tipos de tabelião: de notas, de registro de contratos marítimos e de protesto de títulos. O tabelião de protestos, conforme artigo 11 do mesmo diploma legal, é competente para, no exercício de seu mister, protocolar documentos de dívida para prova do descumprimento da obrigação; intimar os devedores dos títulos para aceitá-los, devolvê-los ou pagá-los, sob pena de protesto; receber o pagamento dos títulos protocolizados, dando quitação ou, caso não houver pagamento, lavrar o protesto, registrando o ato em livro próprio, podendo ainda acatar pedido de desistência do protesto sempre que interessante ao apresentante.

A função possui regramento próprio, tratado na Lei $n^{\circ}$ 9.492/97, que reitera, em seu artigo $3^{\circ}$, as competências do tabelião acima descritas e trata de minúcias do procedimento de protesto $^{596}$, destacando-se, no artigo $7^{\circ}$, a já citada necessidade de distribuição nas localidades em que houver mais de um Tabelionato de Protesto de Títulos, e, no artigo 37, a remuneração do serviço por emolumentos fixados em lei e pagos diretamente pelas partes.

Na proposta de desjudicialização aqui tratada, pretende-se que o tabelião de protesto, porquanto já habituado a lidar com o cumprimento de obrigações de pagar quantia, assuma as vezes de escrivão judicial, utilizando seu tabelionato como órgão análogo ao cartório judicial, praticando todos os atos de cunho não jurisdicional que se revelarem necessários para a execução.

Os escrivães judiciais são profissionais que intermediam a relação entre o gabinete e o cartório judiciais. Neste mister, coordenam e supervisionam as tarefas de seus subordinados no cartório - em regra, escreventes judiciais - enquanto, simultaneamente,

${ }^{596} \mathrm{O}$ artigo $1^{\mathrm{o}}$ da mencionada Lei $\mathrm{n}^{\mathrm{o}}$ 9.242/97 define protesto como "ato formal e solene pelo qual se prova a inadimplência e o descumprimento de obrigação originada em títulos e outros documentos de dívida.". Para os fins aqui pretendidos, basta ressaltar a sua função de cobrança de obrigações pagar quantia, a evidenciar aptidão prévia deste órgão com a atividade. 
prestam assistência ao juiz. A função tem previsão nos artigos 152 a 155 do Novo Código de Processo Civil ${ }^{597}$ e contempla, essencialmente, todas as atividades necessárias à efetivação das ordens judiciais, assistência em audiências, guarda e responsabilidade sobre autos judiciais, expedição de certidões e realização de atos não-jurisdicionais.

Na condição de auxiliares permanentes do juízo, seguem os parâmetros já definidos quanto ao princípio do juiz natural, ou seja, a eles se aplica apenas de forma reflexa, haja vista que atuam vinculados e subordinados ao respectivo juízo ou tribunal, este sim, submetido às exigências do princípio.

De igual modo, a condição de auxiliares permanentes repercute no que concerne à imparcialidade, à qual estão submetidos por um dever geral, podendo se afastarem ou serem afastados de determinado feito mediante suspeição ou impedimento, além de remunerados pelo Estado e sujeitos aos mesmos direitos e deveres dos agentes públicos, notadamente aos princípios da administração, sem usufruírem de inamovibilidade ou vitaliciedade.

Em que pese os auxiliares permanentes, em maioria, serem investidos por concurso público, a investidura dos escrivães judiciais ocorre de modo diverso, se dando, em regra, por nomeação direta, em função de confiança ou cargo comissionado. Desse modo, a escolha conta com alguns poucos critérios objetivos, notadamente as restrições impostas pela Resolução ${ }^{\text {o }}$ 156/2012 do Conselho Nacional de Justiça ${ }^{598}$ e pela qualificação profissional imposta pela lei que regulamenta o cargo no respectivo Tribunal ${ }^{599}$.

${ }^{597}$ O tratamento do Novo Código de Processo Civil praticamente reitera o teor dos artigos 140 a 144 do Código atual. Foi acrescentado apenas o artigo 153, que impõe dever do escrivão, correlato ao do juiz, de respeitar, preferencialmente - termo introduzido pelo Projeto de Lei no 168/2015, encaminhado à sanção presidencial em dezembro de 2015 -, ordem cronológica para publicação e efetivação dos pronunciamentos judiciais, sob pena de responsabilidade administrativa disciplinar.

598 A resolução proíbe a nomeação de pessoas com condenações, por improbidade administrativa ou determinados tipos de crimes dolosos, com trânsito em julgado ou por decisão colegiada. Na mesma vedação incidem pessoas que tenham sido excluídas do exercício da profissão, praticado atos causadores de perda de cargo público ou tiverem rejeitadas contas de modo a configurar irregularidade insanável passível de caracterizar ato doloso de improbidade administrativa.

${ }^{599}$ No estado de São Paulo, os artigos 30 e 41 da Lei Complementar n ${ }^{\circ}$ 1.111/2010, que institui o plano de cargos e carreiras dos servidores do respectivo Tribunal de Justiça, exigem como pré-requisitos para o cargo de Coordenador, equivalente ao escrivão judicial por força do Provimento $n^{\circ}$ 2.038/2013 do Conselho Superior da Magistratura, o preenchimento de $90 \%$ dos cargos por servidores públicos titulares de cargos efetivos, além de ensino superior completo. 
A assunção destes atos hoje praticados pelo escrivão e seus subordinados pelo tabelião de protesto não afeta o monopólio ou inafastabilidade de jurisdição. Como aos escrivães e seus subordinados não é dada a prática de atos de cunho jurisdicional e com os juízes permaneceria a competência para estes atos de cunho decisório e impositivo, a desjudicialização nos moldes propostos passa ao largo da discussão.

Quanto à imparcialidade e naturalidade dos agentes, há de se reconhecer que o tabelião de protesto possui os mesmos mecanismos dos escrivães para promover estes aspectos, sendo possível identificar até mesmo elementos adicionais para os tabeliães.

No que concerne ao princípio do juiz natural, enquanto os escrivães são designados conforme o juízo para o qual foi distribuído o processo - e, assim, o princípio lhes afeta indiretamente, apenas - os tabeliães possuem sistema próprio para distribuição de títulos levados a protesto, que pode ser estendido para a distribuição de feitos executivos.

De igual modo, a investidura por meio de concurso público e a inamovibilidade são garantias existentes nos tabeliães e que não se estendem, necessariamente, os escrivães. A exigência de concurso público para escrivães, a depender do tribunal, pode ser dispensada, sendo facultado o exercício da função por agentes não efetivos. Em se tratando de funções ou cargos comissionados, a independência dos escrivães é bastante reduzida e a correspondência entre a qualificação necessária e a oferecida pelo agente não é garantida. Quanto à inamovibilidade, inexistente nos escrivães, trata-se de garantia que também permite maior independência do profissional, essencial no caso do tabelião, que necessita de liberdade para organizar sua atividade, com os tratos e distratos contratuais que forem necessários para o desempenho da atividade da forma mais efetiva possível.

A principal questão que demanda atenção em termos de imparcialidade nesta desjudicialização, diz respeito aos servidores subordinados a cada um dos agentes. Enquanto os subordinados dos escrivães judiciais são agentes públicos, notadamente escreventes, para os quais se aplica o regime de imparcialidade voltado aos auxiliares permanentes do juízo em geral, os prepostos dos tabeliães, também denominados escreventes pelo artigo 20 da Lei 
$\mathrm{n}^{\text {o }}$ 8.935/94, são empregados privados, contratados pelo tabelião com remuneração livremente ajustada, atrelados ao regime da legislação trabalhista ${ }^{600}$.

A diferença, contudo, não abala substancialmente a segurança jurídica da execução desjudicializada aqui proposta. Assim como o dever de imparcialidade do juiz repercute na atividade dos auxiliares da justiça, o dever de imparcialidade do tabelião também se reflete em seus subordinados, tal como se depreende do entendimento sistemático dos artigos 20 a 22 da Lei $n^{\circ} 8.935 / 94$, os quais preveem que escreventes somente poderão praticar os atos que o tabelião autorizar, que o gerenciamento administrativo e financeiro dos serviços notariais e de registro é da responsabilidade exclusiva do respectivo titular e que o tabelião responde pelos danos que ele e seus prepostos causarem a terceiros na prática de atos próprios da serventia, assegurado direito de regresso no caso de dolo ou culpa dos prepostos.

Ademais, a condição de empregador, associada à previsão, no $§ 2^{\circ}$ do artigo 15 da Lei $n^{\circ} 8.935 / 94$, de que o tabelião deve ser bacharel em direito ${ }^{601}$, confere qualificação suficiente a este profissional para a criação de mecanismo de controle, interno ao próprio tabelionato e sem prejuízo das vias judiciais, para imediato saneamento de eventuais conflitos de parcialidade que surgirem com os prepostos.

${ }^{600}$ CENEVIVA, Walter. Lei dos notários e dos registradores comentada (Lei n. 8935/94). 6 ed. São Paulo: Saraiva, 2007, p. 170. O autor destaca, ainda, a vedação para terceirização da atividade fim, que deve ser mantida para fins da desjudicialização aqui proposta, uma vez que a delegação feita pelo Poder Público diz respeito à pessoa do tabelião, extensível somente a seus prepostos que atuam por intermédio e sob a responsabilidade direta do titular, de modo a manter sob controle os parâmetros constitucionais para o exercício das atividades. Esta vedação deve se manter e a justificativa deve ser aplicada para, a priori, impedir a terceirização das atividades dos tabelionatos independentemente do desfecho do Projeto de Lei n $^{\circ}$ 4330/2004, atualmente em trâmite no Senado Federal - já aprovado na Câmara dos Deputados. Isto porque o texto encaminhado à casa revisora autoriza a terceirização de qualquer parcela de atividade da contratante, indistintamente, e a vedação para tanto no âmbito público, prevista no $§ 2^{\circ}$ do artigo $1^{\circ}$ do Projeto, é restrita à administração pública direta, autárquica e fundacional, não abrangendo de forma expressa, portanto, os tabelionatos, que são particulares atuando mediante delegação.

${ }^{601}$ Diga-se, a propósito, que a qualificação jurídica do tabelião é elemento favorável no que condiz à sua capacitação para lidar com a ampla gama de instrumentos executivos operados pelo Judiciário, sendo, teoricamente, capaz de intermediar a relação entre juiz e o tabelionato de forma tecnicamente mais apurada (HESS, Burkhard. Different enforcement structures. In: VAN RHEE, C.H.; UZELAC, Alan (coord.). Enforcement and enforceability - tradition and reform. Antwerp, Oxford, Portland: Intersentia, 2010, p. 50). 
Esta perda quanto aos escreventes, que já pode ser minorada pela possibilidade de controle e responsabilidade direta do tabelião, pode ser mitigada ainda pelas vantagens de se contar com a gestão administrativa e financeira privadas dos recursos necessários ao deslinde do processo executivo ${ }^{602}$.

O tabelião pode congregar em seu ofício não só as funções do escrivão e escreventes judiciais, mas também de outros auxiliares permanentes, como os oficiais de justiça notadamente a feitura de citações, penhoras, arrestos, dentre outras funções previstas no artigo 154 do Novo Código de Processo Civil -, além de intermediar, sempre que necessário, o acionamento de auxiliares eventuais como leiloeiros, peritos avaliadores e depositários, utilizando, inclusive, o mesmo mecanismo de credenciamento e as mesmas regras hoje aplicadas aos cartórios judiciais.

Além disso, como tem ampla liberdade para gerir seu serviço, o tabelião pode aumentar ou diminuir sua estrutura conforme a demanda de processos e as metas de produtividade estabelecidas pelos órgãos de controle do Judiciário, notadamente o Conselho Nacional de Justiça e os respectivos Tribunais aos quais estão atrelados os tabelionatos. Estas adequações poderão ser feitas com menor burocracia e sem a dependência de dotações orçamentárias do Estado, haja vista que o custeio do serviço deve se dar, isolada ou cumulativamente, a depender de prévio estudo de viabilidade econômico-financeira, por emolumentos fixados em lei, que podem ser progressivos conforme a fase avançada no processo $^{603}$, antecipados pela parte exequente e pagos ao final pela parte sucumbente, ou por

\footnotetext{
${ }^{602}$ Por gerenciamento administrativo entende-se o controle de bens s pessoal e por gerenciamento financeiro entende-se o controle das entradas e saídas de dinheiro (CENEVIVA, Walter. Lei dos notários e dos registradores comentada (Lei n. 8935/94). 6 ed. São Paulo: Saraiva, 2007, p. 180).

${ }^{603}$ MARSTON, John. Fee systems for enforcement agents. In: VAN RHEE, C.H.; UZELAC, Alan (coord.). Enforcement and enforceability - tradition and reform. Antwerp, Oxford, Portland: Intersentia, 2010, p. 329. Os emolumentos progressivos, antecipados pelo exequente conforme a fase avançada no processo, foram utilizados na desjudicialização portuguesa. O artigo 47 da Portaria $n^{\circ}$ 282/2013 prevê quatro fases, iniciadas, respectivamente, com a verificação da regularidade do título executivo, citação do executado, realização de diligências de penhora e, finalmente, diligências de venda, liquidação e pagamento. Em sua proposta de desjudicialização para a execução por quantia brasileira, Flávia Pereira Ribeiro sugeriu esta espécie de remuneração para os tabelionatos, ressaltando, porém, a necessidade de estudo dedicado para definição do assunto (A desjudicialização da execução civil. São Paulo: Saraiva, 2013, p. 179).
} 
percentual do crédito recuperado, dentro de parâmetros previamente fixados em lei. Contribui a esta opção a nova previsão do inciso XI do artigo 784 do Novo Código de Processo Civil, que prevê, expressamente, no rol de títulos executivos extrajudiciais a certidão expedida por serventia notarial ou de registro relativa a valores de emolumentos e demais despesas devidas pelos atos por ela praticados, agilizando a cobrança de tais importâncias quando necessário ${ }^{604}$.

Assim, em síntese, de acordo com a proposta de desjudicialização aqui trazida, os tabeliães de protesto assumiriam a responsabilidade pela coordenação, supervisão e realização dos atos não jurisdicionais da execução, bem como pela intermediação da relação de seu tabelionato com o juiz, autoridade responsável pela prática dos atos jurisdicionais, de forma análoga à que hoje ocorre com o escrivão judicial e seus subordinados. Praticariam todos os atos desta natureza, tais como controle e movimentação de autos, elaboração de requerimento de pesquisa junto ao sistema Bacenjud ${ }^{605}$, minutas de decisões, despachos de mero expediente, elaboração e encaminhamento de mandados, dentre outras providências que forem oportunamente necessárias.

Para este mister, teriam liberdade para organizar seus ofícios de forma a atender a demanda de processos e as metas estabelecidas pelos órgãos de controle, inclusive

\footnotetext{
${ }^{604}$ Quando a execução versar sobre créditos do próprio tabelionato, somente será possível que a execução tramite de forma desjudicializada caso exista outro tabelionato capaz de dar andamento ao feito, sob pena de quebra da imparcialidade. Nas localidades em houve um único tabelionato apto, a execução deverá tramitar em cartórios judiciais.

${ }^{605}$ Registre-se que a utilização do sistema para requerimentos do sistema Bacenjud pelo tabelião e seus subordinados é indiferente para fins de direito à intimidade e ao sigilo, constitucionalmente garantidos pelos incisos X e XII do artigo $5^{\circ}$. Primeiramente porque o tabelião não é, propriamente, encarregado da pesquisa ou de sua requisição, mas, tão-somente, do preenchimento do requerimento, o qual, necessariamente, deve ser subscrito pelo juiz. Além disso, o artigo 655-A, caput e $\$ 1^{\circ}$ do Código de Processo Civil autorizam o magistrado a apenas requisitar informações sobre a existência de ativos em nome do executado, limitada a pesquisa ao valor do débito, sendo raros os equívocos neste sentido (LUPOI, Michele Angelo; LUCON, Paulo Henrique dos Santos; COSTA, Guilherme Recena. Brazilian report on the use of new information technology in the enforcement of judgments. Revista de Processo, São Paulo, ano 36, vol. 194, abr. 2011, p. 318), além de vedadas divulgações de informações sobre saldo da conta bancária, valores aplicados ou movimentações financeiras que não forem relevantes para a causa (REDONDO, Bruno Garcia; LOJO, Mário Vitor Suarez. Ainda e sempre a penhora on-line: constitucionalidade, princípios e procedimento. In: DIDIER JUNIOR, Fredie (coord.). Leituras complementares de Processo Civil. 8 ed. Salvador: Editora Juspodivm, 2010, p. 102103). Ademais, em não se tratando o sigilo bancário de direito absoluto, a sua relativização para fins executivos, ainda mais nos cautelosos termos da lei, é legítimo (RAMOS, José Eduardo Ferreira. O sigilo bancário frente ao direito fundamental à tutela jurisdicional efetiva. In: GUNTHER, Luiz Eduardo (coord.). Jurisdição: crise, efetividade e plenitude institucional. Curitiba: Juruá, 2009, p. 345).
} 
congregando outras funções de auxiliares permanentes e intermediando a nomeação dos auxiliares eventuais que se revelarem necessários para o deslinde do processo executivo.

\subsection{Juízo da execução}

O juiz responsável pela prática de atos jurisdicionais que digam respeito à execução é o mesmo que hoje cuida desta sorte de processos. Ficam mantidas as regras de competência e, de modo geral, as atividades desenvolvidas por este profissional no que concerne ao proferimento de decisões e determinações e à direção do processo e controle dos atos processuais praticados.

Como visto, a atuação do juiz na execução é reduzida e, em geral, pragmática. Em regra, na execução em si, o magistrado apenas confere e ratifica os atos já previamente elaborados pelo cartório, atuando com maior intensidade nas questões que exigem declaração de direitos, caso dos mecanismos ordinários de defesa - embargos e impugnação ao cumprimento de sentença - e dos incidentes de conhecimento no curso da execução, como no caso de penhora de bem de família.

Diante disso, e com a realização dos atos de forma eletrônica, a interação entre o juiz, o tabelionato e as partes tende a funcionar regularmente, sem necessidade de grandes alterações.

A distinção fica por conta da segmentação entre o juiz e o cartório. Uma vez que não está sob seu controle hierárquico, já que o tabelionato é independente, o juiz deixa de ser responsável direto pelo cartório, tarefa que, nesta hipótese desjudicializada, incumbe ao tabelião. Assim, eventuais danos causados pelos atos não jurisdicionais transferidos ao tabelionato, bem como questões concernentes à atividade desempenhada no tabelionato e que não tenham relação direta com a demanda, devem ser, ao menos em um primeiro momento, de responsabilidade do tabelião, e não do juízo.

Esta independência, contudo, não exime o tabelião de ser obrigado, por lei, a cumprir com o seu mister, qual seja, de administrar a tramitação do processo, dando cumprimento às ordens judiciais que disserem respeito à lide. 
É de se esperar que, com o sucesso da alternativa desjudicializada, esta ampliação da atividade não jurisdicional sobrecarregue a atividade jurisdicional, passando a haver grande congestionamento de processos para apreciação e decisão do juízo.

Para este problema, contudo, não se entende a desjudicialização como técnica mais adequada. Considerando as peculiaridades da desjudicialização de atos jurisdicionais e os delicados aspectos jurídicos e sociais já destacados, a solução deve ser buscada, ao menos num primeiro momento, em técnicas extraprocessuais ${ }^{606}$, ou seja, na busca por um maior rendimento do sistema judiciário em si, do aparato disponibilizado ao juiz para o exercício da função jurisdicional em sua atividade nuclear, dentro da própria estrutura do Poder Judiciário. Dentre as providências destaca-se a contratação de mais assessores diretos do juízo, aumento no número de juízes auxiliares ou, até mesmo, a criação de vara especializada para lidar com processos executivos.

Estas providências, contudo, somente devem ser verificadas num segundo momento, a partir de análise criteriosa dos efeitos da implantação da desjudicialização aqui sugerida e das causas da morosidade para realização dos atos jurisdicionais.

\subsection{Juízo corregedor}

Em geral, países que adotam a desjudicialização privada contam com um duplo sistema de controle dos agentes externos: um para os atos praticados por estes agentes e outro para suas condutas profissionais ${ }^{607}$.

Tendo em vista esta duplicidade, na proposta confere-se o controle jurisdicional regularmente exercido sobre os atos do processo executivo pelo juízo competente para a

${ }^{606}$ GAJARDONI, Fernando da Fonseca. Técnicas de aceleração do processo. São Paulo: Lemos \& Cruz, 2003, p. 75.

607 HESS, Burkhard. Different enforcement structures. In: VAN RHEE, C.H.; UZELAC, Alan (coord.). Enforcement and enforceability - tradition and reform. Antwerp, Oxford, Portland: Intersentia, 2010, p. 52. 
execução, os quais devem ser suficientes para coibir a maior parte das irregularidades que porventura surjam no processo executivo, e, para a conduta profissional, fica mantida a figura do juízo corregedor.

O juízo corregedor é a figura que atende pelo dever de fiscalização do Poder Judiciário sobre as serventias extrajudiciais estabelecido no $\S 1^{\circ}$ do artigo 236 da Constituição Federal e que incide sobre o exercício das atribuições e competências dos tabeliães ${ }^{608}$.

Sua previsão originária se dá no artigo 37 da Lei nº 8.935/94 e a regulamentação da atividade se dá em cada Tribunal. O Regimento Interno do Tribunal de Justiça do estado de São Paulo prevê, em seu artigo 28, a figura do Corregedor Geral de Justiça, a quem incumbe, por meio dos respectivos juízes corregedores permanentes de cada comarca, fiscalizar, em caráter geral e permanente, as atividades das delegações notariais e de registro.

Esta atividade é exercida, principalmente, com correições ordinárias e extraordinárias e visitas às unidades delegadas, sempre que necessário, bem como com o recebimento e processamento de reclamações contra titulares e funcionários das delegações notariais e de registro, aplicando as penalidades cabíveis após sindicâncias e processos administrativos, inclusive no que concerne à aplicação da legislação sobre emolumentos.

Além da função correcional e disciplinar, cuidam os juízos corregedores de propor as medidas convenientes ao aprimoramento dos serviços das delegações notariais e de registro, designar substituto, nos casos previstos em lei, dos titulares e serventuários das delegações de notas e de registro, determinar, quando necessário, a intervenção nas delegações, designando interventor na forma da lei, com ou sem o afastamento do titular, estabelecer as normas de serviço das delegações notariais e de registro, dentre outras providências que se revelarem pertinentes para o aprimoramento da atividade delegada.

Estas atribuições são distintas e independentes da função exercida pelo juízo competente para atuar no processo executivo. Não cabe a este a fiscalização do tabelionato

${ }^{608}$ CENEVIVA, Walter. Lei dos notários e dos registradores comentada (Lei n. 8935/94). 6 ed. São Paulo: Saraiva, 2007, p. 273. 
ou do tabelião, mas, tão-somente, a coordenação e fiscalização dos atos do processo executivo, sem qualquer colisão de interesses com o juízo corregedor.

Tanto é que, no estado de São Paulo, o mesmo Corregedor Geral de Justiça supracitado é encarregado de fiscalizar, também, em caráter geral e permanente, as atividades dos cartórios judiciais.

Como dito, a existência de um cartório independente, sob a coordenação do tabelião, implica na responsabilização deste último pela atividade ali desenvolvida, afastando, ao menos num primeiro momento, a responsabilidade do juiz da execução. Correições, aferições disciplinares e demais assuntos que guardem relação com a atividade desenvolvida dentro do tabelionato, mas não se relacionem diretamente com a demanda executiva, devem ser solucionados perante o tabelião e o respectivo juiz corregedor, de acordo com os mecanismos próprios para tanto.

\subsubsection{Síntese do procedimento}

Inicialmente, há de se observar que a viabilidade da proposta pressupõe a realização dos atos de forma eletrônica sempre que possível, inclusive com a tramitação da execução em autos digitais. Não só pelas vantagens do processo eletrônico, no que condiz ao acesso à justiça, acessibilidade e transparência dos atos processuais ${ }^{609}$, mas também e, aqui, principalmente, quanto ao aspecto da fluide $\mathrm{z}^{610}$, mobilidade, praticidade ${ }^{611}$ e custo do processo eletrônico.

\footnotetext{
${ }^{609}$ ALMEIDA, Patrícia Martinez; SILVEIRA, Vladmir Oliveira da. Processo judicial eletrônico e segurança de dados: a proteção digital como novo direito humano. Revista mestrado em direito, Osasco, ano 13, $\mathrm{n}^{\circ} 2, \mathrm{p}$. 323-343, jul.-dez. 2013, p. 340.

${ }^{610}$ LUPOI, Michele Angelo. Enforcement of a claim with the support of the new information technology. Revista de processo, São Paulo, ano 36, vol. 193, mar. 2011, p. 341.

611 ARONNE, Bruno da Costa. O impacto da informatização judicial sobre os princípios do processo civil. Revista eletrônica de direito processual, Rio de Janeiro, ano 2, vol. II, jan.-dez. 2008, p. 88.
} 
Ainda que a questão do custo do processo, assim como a forma de remuneração do serviço, somente poderá ser devidamente compreendida e resolvida após estudo de viabilidade econômico-financeira da iniciativa, é dedutível que a prática de atos físicos, bem como a tramitação em autos desta natureza, exigiria grande logística entre os tabelionatos e as varas judiciais ${ }^{612}$, o que não ocorre nos autos eletrônicos, veículo mais rápido e econômico para que a informação possa chegar às mãos do magistrado ${ }^{613}$, de modo contribuir positivamente com o custo do processo ${ }^{614}$.

Ademais, a via eletrônica se coaduna com a tendência evolutiva do processo executivo brasileiro, cada vez mais informatizado não só em termos de autos processuais desde o advento da Lei ${ }^{\circ}$ 11.419/06 -, mas também para a realização dos atos de penhora de créditos e bens sujeitos a registro ${ }^{615}$ e, conforme já mencionado, na alienação por leilão eletrônico ${ }^{616}$.

Isto posto, há de se observar que, tendo em vista a inexistência de alterações quanto aos atos de natureza jurisdicional, a estrutura procedimental não precisa ser submetida a grandes mudanças.

De modo geral, fica mantido o procedimento do atual Código de Processo Civil, repetido, em essência, no vindouro Novo Código de Processo Civil. Há algumas poucas diferenças necessárias para adequação da técnica e otimização da proposta.

A primeira delas diz respeito ao requerimento inicial da execução, quer seja cumprimento de sentença, quer seja execução autônoma. Na ocasião de sua formulação, o

\footnotetext{
${ }^{612}$ A logística foi um problema identificado na primeira etapa da reforma portuguesa, quando ainda não tinha sido implantado o processo eletrônico (PIMENTA, Paulo. Reflexões sobre a nova acção executiva. Sub Judice: justiça e sociedade, Coimbra, $\mathrm{n}^{\circ}$ 29, out./dez. 2004, p. 83)

${ }^{613}$ DANTAS NETO, Renato de Magalhães. Autos virtuais: o novo layout do processo judicial brasileiro. Revista de Processo, São Paulo, ano 36, vol. 194, abr. 2011, p. 200.

${ }^{614}$ LUPOI, Michele Angelo. Enforcement of a claim with the support of the new information technology. Revista de processo, São Paulo, ano 36, vol. 193, mar. 2011, p. 342.

615 Idem.

${ }^{616}$ SICA, Heitor Vitor Mendonça. Tendências evolutivas da execução civil brasileira. Relatório preparado para o "I Colóquio Brasil-Itália de Direito Processual Civil”, São Paulo - SP, em 29 ago. 2014.
} 
exequente deve manifestar, expressamente, sua intenção de se prevalecer do procedimento desjudicializado, já adiantando eventuais valores devidos a título de custas.

O momento seguinte é variável conforme o tipo de procedimento executivo. Caso seja cumprimento de sentença, o juiz recebe o requerimento e dentre as demais providências, notadamente a intimação do executado, determina a sua distribuição perante o ofício distribuidor dos tabelionatos de protesto. Esta distribuição é necessária não só como reflexo do princípio do juiz natural, mas também para que os tabelionatos existentes atuem em igualdade quanto aos processos, sem qualquer tipo de discriminação quanto às partes envolvidas ou o valor cobrado, respeitando a mesma lógica aplicada aos títulos levados a protesto $^{617}$. Evidentemente que, caso haja apenas um tabelionato de protesto na localidade, a distribuição é dispensada, determinando o juiz apenas a respectiva comunicação e transferência direta dos autos digitais.

O cartório judicial, ciente da determinação, limita-se a cumprir o encaminhamento do feito ao tabelionato, determinação que deve anteceder quaisquer outras. O tabelião, com ou sem distribuição, recebe o feito de imediato e, sem possibilidade de recusa neste primeiro momento, passa a cumprir as demais determinações judiciais constantes do despacho inicial.

Em se tratando de execução autônoma, o credor deve distribuir a inicial executiva, informando na petição a opção pela via desjudicializada e já antecipando os valores pertinentes. $\mathrm{O}$ feito é distribuído e então o juízo que o receber adota o trâmite descrito acima.

Alternativamente, pode ser criado recurso que unifique os sistemas eletrônicos de protesto e execução. Neste caso, seria facultado ao credor levar seu título a protesto já com pedido de execução. O tabelião designado pelo ofício distribuidor adotaria os trâmites de praxe que, decorridos sem o adimplemento, permitiriam a lavratura, registro e publicação do protesto, tal como se dá atualmente nos termos dos artigos 20 e seguintes da Lei $n^{\circ}$ 9.492/97. Atingida esta etapa, o tabelião comunicaria o credor para recolhimento dos valores devidos em razão da execução e passaria à fase seguinte, distribuindo o requerimento do credor em

${ }^{617}$ CENEVIVA, Walter. Lei dos notários e dos registradores comentada (Lei n. 8935/94). 6 ed. São Paulo: Saraiva, 2007, p. 91. 
juízo e iniciando o processo executivo, do qual ficaria responsável pela prática dos atos não jurisdicionais.

Questão interessante concerne à postura do devedor perante a opção do credor pelo procedimento desjudicializado. Uma vez oportunizado oferecimento de defesa, lhe é lícita a oposição ao procedimento alternativo? Em outras palavras, há direito do executado de que a sua defesa seja processada por cartório judicial? A resposta é negativa.

Conforme já enfrentado, a garantia de inafastabilidade do controle jurisdicional exercido pelo Poder Judiciário, garante a qualquer pessoa uma tutela dali proveniente, o que já ocorre na desjudicialização aqui tratada. Não há justificativa para se extrair do dispositivo a extensão da garantia para os agentes responsáveis pelos atos não jurisdicionais do feito, notadamente na execução, em que a liberdade de ajuizamento da demanda, dentro das possibilidades legais, da forma que for mais conveniente ao demandante, é direito ainda mais consistente diante da presunção de reconhecimento do direito material do exequente expressa no título executivo ${ }^{618}$.

Ademais, este cenário de submissão do executado a agentes não integrantes do Poder Judiciário já se apresenta no direito brasileiro, quando, por exemplo, o juiz designa um perito privado para avaliar um bem do executado ou quando um leiloeiro privado é designado para alienar um bem penhorado do executado. Em qualquer dessas hipóteses, a simples condição de o agente não integrar os quadros do Poder Judiciário não invalida o ato praticado.

No que concerne à isonomia, consigne-se que a escolha do procedimento não é livre de ônus ao exequente, que corre o risco de ver a situação revertida em juízo, podendo ser responsável único por arcar com todas as despesas processuais. Quanto ao executado, entende-se que a submissão à via escolhida pelo exequente é compatível com o desequilíbrio em que ambos se encontram no campo do direito material. Ainda assim, há de se garantir que eventuais custos antecipados pelo executado para exercitar seu contraditório na via desjudicializada seja o mesmo que teria de dispender para atuar na via judicializada.

${ }^{618}$ SAMPAIO, J.M. Gonçalves. A acção executiva e a problemática das execuções injustas. 2 ed. Coimbra: Edições Almedina, 2008, p. 450. 
Logo, em todas as oportunidades em que o executado exercitar o contraditório, quer seja em incidentes processuais, quer seja nas vias típicas de defesa, inclusive embargos, serão processados no cartório desjudicializado, perante o tabelião.

Por fim, observe-se que, caso o tabelião ou as partes tenham quaisquer objeções ao desempenho de suas atividades, tais como as restrições impostas pelos artigos 25 a 27 da Lei $\mathrm{n}^{\circ} 8.935 / 94$, seu impedimento ou suspeição ou questões relativas ao custeio de seu serviço, devem provocar o juiz corregedor do tabelionato, sem prejuízo de o tabelião permanecer exercendo suas atividades até deliberação final. Eventual decisão que inviabilize o prosseguimento do feito na via desjudicializada deverá ser comunicada ao juízo da execução, tornada pública às partes do feito executivo, o processo encaminhado ao cartório judicial e eventuais custas adiantadas que não puderem ser aproveitadas devolvidas às partes quando não lhes couber a culpa pelo ocorrido.

\subsubsection{Proveito para a razoável duração do processo}

Finalmente, cabe analisar o proveito para razoável duração do processo do modelo proposto. Aqui cabe uma reflexão com base nas três vertentes de melhorias esperadas numa iniciativa de desjudicialização, acima destacadas, quais sejam, possibilidade de especialização, a desvinculação das administrações orçamentária e de pessoal e a redução no consumo de tempo e recursos do Poder Judiciário.

A primeira vertente, possibilidade de especialização, é atendida pela proposta. $\mathrm{O}$ tabelionato de protesto, em si, já é um órgão especializado na cobrança de obrigações de pagar quantia, enquanto os cartórios judiciais arcam com uma ampla gama de processos e atos. O intercâmbio entre o know how dos tabelionatos de protesto e os mecanismos disponibilizados ao juízo para satisfação da execução tende a ser benéfico para ambas as partes, capaz de proporcionar, no futuro, interações que repercutam não só na celeridade, mas também na efetividade da cobrança de obrigações de pagamento de quantia, tanto antes do acionamento judicial, quanto durante o processo executivo.

Ademais, a busca pelo serviço desjudicializado, provavelmente mais caro que o judicializado, somente ocorrerá caso ele consiga se provar mais eficaz em seu mister do que a alternativa. Esta circunstância, associada ao controle de metas do Conselho Nacional de Justiça, que há de ser estendido aos tabelionatos enquanto no exercício de atividades 
relacionadas ao processo executivo, deve impulsionar estes órgãos para a constante adaptação e melhoria de suas atividades.

Não se olvide, ainda, o aspecto da formação jurídica do tabelião, certamente útil na intermediação entre o juiz e o tabelionato, não só de forma política, mas também técnicojurídica, como espécie de filtro interno dos atos processuais. Em que pese isto também ocorrer com boa parte dos escrivães, não há exigência legal, de âmbito nacional, para que estes profissionais tenham esta formação.

A segunda, desvinculação das administrações orçamentária e de pessoal, também é atendida pela proposta. Como abordado em diversas oportunidades, a atividade do tabelionato terá forma de custeio própria, definida a partir de estudo de viabilidade econômico-financeira, mas que deve ser independente do orçamento público. O mesmo se dá com o corpo funcional do tabelionato, que já existe com critérios e métodos próprios para contratação, seleção e custeio e assim permanecerá, a critério do tabelião, de forma independente do que é praticado pelo Poder Judiciário.

Não se olvide que estes aspectos se darão em núcleos gerenciais e orçamentários sobejamente reduzidos quando comparados com o Poder Judiciário, o que contribui para a agilização na circulação de informações e recursos, com facilitação no atendimento das demandas internas, tais como treinamento e desenvolvimento do capital intelectual dos funcionários, valorização de remunerações ${ }^{619}$, substituição e reposição de pessoal, aparelhamento da estrutura, contratação e rescisão de prestadores de serviço, dentre outras demandas que, em regra, são dificultosas no âmbito público e que são relevantes para uma maior profissionalização da atividade ${ }^{620}$.

${ }^{619}$ NOGUEIRA, Eliane Garcia. Juiz-gestor - Gestão judiciária e eficiência da justiça. Revista da Ajuris, Porto Alegre, Ano XXXVI, n 113, mar. 2009, p. 144.

${ }^{620}$ ANDRADE, Érico. As novas perspectivas do gerenciamento e da "contratualização" do processo. Revista de processo, São Paulo, ano 36, vol. 193, mar. 2011, p. 196. 
Ademais, a hipótese aventada, dada a liberdade de administração e contratações conferida ao tabelião, pode, inclusive, trazer melhorias no que diz respeito à gestão do fluxo de rotinas internas dos tabelionatos, postura já identificada pela doutrina como grande responsável pela melhora no tempo de tramitação dos processos quando aplicada aos cartórios judiciais ${ }^{621}$. Esta melhoria pode ser almejada com a pressão de metas impostas pelo Conselho Nacional de Justiça ${ }^{622}$ - que podem, inclusive, ser mais ambiciosas que aquelas impostas aos cartórios judiciais - ou com a exigências diretas de treinamentos e capacitações dos tabeliães.

Por fim, para a terceira vertente, redução no consumo de tempo e recursos do Poder Judiciário, há de se considerar que "não se alteram mentalidades por decreto"623. Trata-se de melhoria que tende a ser progressivamente alcançada, quanto maior o sucesso da iniciativa, quanto mais a alternativa desjudicializada for acionada em detrimento da judicializada, quanto mais se superar a cultura judiciarista tradicional ${ }^{624}$.

A oportunidade de mover execuções de maneira mais célere, ainda que potencialmente mais custosa, é tentadora para qualquer credor, mas, principalmente, para os bancos, maiores dentre os cem maiores litigantes, responsáveis, em 2011, por 53,5\% do total de processos que tramitaram na Justiça Estadual, e que lidam amplamente com a execução de obrigações de pagar quantia ${ }^{625}$. Assim sendo, é de se esperar que, num primeiro momento, a via judicial se mantenha sobrecarregada, até que, com o tempo e eventuais ajustes que se relevarem necessários - rememorando o histórico da desjudicialização portuguesa -, a alternativa desjudicializada se estabilize como caminho viável, célere e seguro, a

${ }^{621}$ SILVA, Paulo Eduardo Alves da. Gerenciamento de processos judiciais. São Paulo: Saraiva, 2010, p. 146. ${ }^{622}$ No exercício de seu papel de "definição de projetos, metas e apresentação de soluções para combater os problemas estruturais, institucionais e funcionais voltados ao aperfeiçoamento da prestação da tutela jurisdicional", aspectos delineados, nos incisos VI e VII do $\S 4 .^{\circ}$ do artigo 103-B da Constituição Federal (FIGUEIRA JÚNIOR, Joel Dias. Projeto legislativo de novo código de processo civil e a crise da jurisdição. Revista dos Tribunais, São Paulo, v. 926, p. 455, dez. 2012, p.464).

${ }^{623}$ FIALHO, António José. Da teoria à prática - Algumas dificuldades na aplicação do novo regime da acção executiva. Sub Judice: justiça e sociedade, Coimbra, nº 29, out./dez. 2004, p. 79.

${ }^{624}$ MANCUSO, Rodolfo de Camargo. A resolução dos conflitos e a função judicial no contemporâneo Estado de Direito. 2 ed. São Paulo: Editora Revista dos Tribunais, 2014, p. 171.

625 Dados coletados de pesquisa elaborada pelo Conselho Nacional de Justiça, disponível em 〈http://www.cnj.jus.br/images/pesquisas-judiciarias/pesquisa_100_maiores_litigantes.pdf >. Acesso em 30 nov. 2015. 
impulsionar a migração de processos, notadamente destes grandes litigantes, e, de fato, aliviar o consumo de tempo e recursos do Judiciário.

Além disso, um segundo movimento de desjudicialização, caso seja proveitosa essa primeira experiência, pode tornar obrigatória a tramitação das execuções de pagar quantia pelos tabelionatos, ou mesmo ampliá-las para outras espécies de obrigação, com impactos ainda mais significativos no descongestionamento ou, ao menos, na redução do ritmo de congestionamento do Judiciário.

Quanto à segurança jurídica, a proposta aqui desenvolvida é cautelosa dentre as possibilidades trazidas pela desjudicialização e, assim, de pouco abalo às garantias do devido processo legal e seus consectários e aos limites naturais e políticos da execução. Há a manutenção quase intacta do processo como ele foi concebido e a ampla supervisão judicial dos atos praticados, quer seja pelo juiz da execução, quer seja pelo juiz corregedor dos tabelionatos, de modo que não se identifica qualquer grande desfalque neste aspecto, a evitar o descarte de antigos e tradicionais institutos processuais ${ }^{626}$.

Se há alguma ressalva a ser feita é a lembrança de que não existem garantias de efetivo aumento de celeridade na execução, haja vista que há uma série de etapas e, dentro de cada uma, variáveis que podem alterar a dinâmica entre aquilo que se projeta e o resultado colhido no mundo dos fatos ${ }^{627}$. Todavia, estas circunstâncias são naturais de qualquer mudança e não há modo de contorna-las senão implantando da forma mais cautelosa possível e trabalhando com as deficiências que se apresentarem na prática.

${ }^{626}$ MORAES, José Rubens de. Direito processual civil uruguaio. In: CRUZ E TUCCI, José Rogério (coord.). Direito processual civil americano contemporâneo. São Paulo: Lex Editora, 2010, p. 342.

${ }^{627}$ BARBOSA MOREIRA, José Carlos. O neoprivatismo no processo civil. In: DIDIER JUNIOR, Fredie (coord.). Leituras complementares de Processo Civil. 8 ed. Salvador: Editora Juspodivm, 2010, p. 345. 


\section{CONCLUSÃO}

Há um problema na razoável duração dos processos executivos que precisa, de fato, ser enfrentado. Cuida-se de tópico caro ao Conselho Nacional de Justiça e antiga preocupação da doutrina.

Relevantes neste quadro, ao menos no que diz respeito à execução por quantia, aqui analisada, são a sobrecarga da estrutura disponível, com intensas utilizações de tempo e recursos dos cartórios judiciais para se promover o andamento dos feitos, uma vez que são encarregados da maior parte dos atos deste tipo de processo, e a pequena margem orçamentária que dispõe o Judiciário para reverter ou melhorar este quadro.

A desjudicialização da execução, enquanto técnica extrajudicial de aceleração do processo, é mecanismo que visa concentrar atos do processo executivo do Poder Judiciário em terceiros externos a ele. Pode assumir diversas formas, administrativas ou privadas, incidentais ou preponderantes, obrigatórias ou meramente alternativas, com transferência de poder jurisdicional ou não.

No ordenamento estrangeiro, seu emprego pôde ser verificado em diversas categorias, quer seja incidental em modelos preponderantemente públicos judicializados, quer seja de forma preponderante em modelos preponderantemente desjudicializados, públicos ou privados.

No ordenamento nacional, desde as primeiras legislações processuais, passando pela evolução histórica, até a atual e futura codificações, verifica-se com alguma frequência a utilização de desjudicializações incidentais, privadas, alternativas e sem transferências de poder jurisdicional, inclusive com ligeira ampliação ao longo do tempo, com cada vez mais agentes externos ao Judiciário auxiliando no desempenho da função jurisdicional. Também na forma preponderante ela já existe, com procedimentos que dispensam a atuação do Judiciário, caso do Decreto-Lei $n^{\circ} 70 / 66$ e Lei $n^{\circ}$ 9.514/97, e com propostas que têm por objetivo mesclar a atuação do Judiciário com a de agentes administrativos, como em uma das propostas de desjudicialização da execução fiscal estudada. 
Trata-se de técnica que, sem prejuízo de permitir inovação, pode ser empregada em consonância com os principais elementos do devido processo legal, tal como concebido no país, inclusive - em regra - com as mesmas estruturas criadas e postas como pilares do sistema jurisdicional, casos do monopólio e inafastabilidade de jurisdição, imparcialidade e naturalidade dos agentes envolvidos na execução e contraditório e ampla defesa.

Diante do cenário de morosidade identificado, uma mudança de modelo processual, de modo a deslocar a execução para fora da estrutura congestionada do Poder Judiciário ganha força como uma dentre as soluções possíveis de aceleração do processo.

Do diagnóstico possível em meio aos dados coletados, uma iniciativa de desjudicialização preponderante, de atos não jurisdicionais, que crie um procedimento alternativo de execução por quantia, cuja tramitação seja majoritariamente perante agentes privados, preservada a competência do juiz nos atos que demandarem a prática de atos de decisão e de imposição de decisões, se revela como alternativa coerente.

Por meio dela, há potencial para se promover melhorias como a possibilidade de especialização do agente desjudicializado, a desvinculação entre as administrações orçamentária e de pessoal do Judiciário e o agente externo, e a redução no consumo de tempo e recursos do Poder Judiciário, com a progressiva redução de atos do processo executivo que sejam de sua incumbência.

Não se olvide, porém, que a confirmação desta expectativa depende do sucesso de sua implantação, com um diagnóstico preciso do problema enfrentado - seria importante um estudo mais extenso e específico sobre os aspectos da morosidade aqui enfrentados em amostragem e a partir de dados gerais, a fim de verificar se a proposta é funcional a um sistema processual civil de âmbito nacional -, seguido de planejamento e estudo aprofundados sobre a viabilidade da desjudicialização pretendida - reitera-se a importância da análise de viabilidade econômico-financeira da iniciativa - e, finalmente, uma implantação conforme o planejamento, etapas que, se falhas, podem comprometer o ideal almejado.

Estas ressalvas, porquanto inerentes a qualquer processo de mudança, não afastam a desjudicialização da execução de sua condição de técnica que pode ser proveitosa para o enfrentamento do congestionamento de processos, principalmente no que concerne à fluidez 
dos atos processuais a cargo do juízo, não só daqueles praticados em processos executivos, mas também, de forma reflexa, daqueles voltados aos processos de conhecimento.

Como observa Barbosa Moreira, no que concerne à morosidade, "não existe fórmula de validade universal para resolver por inteiro a equação. Temos de combinar estratégias e táticas, pondo de lado o receio de parecermos incoerentes e, para enfermidades de diferente diagnóstico, experimentarmos remédios também diferenciados"628.

A desjudicialização executiva, seguramente, não é a solução definitiva e universal para a morosidade do processo. Todavia, com a mesma segurança, deve ser encarada como remédio funcional a alguns aspectos deste quadro, capaz de funcionar como importante agente do movimento de melhoria e aprimoramento da tutela jurisdicional. 


\section{REFERÊNCIAS BIBLIOGRÁFICAS}

A

ABELHA RODRIGUES, Marcelo. Manual de execução civil. 2 ed. Rio de Janeiro: Forense Universitária, 2007.

; JORGE, Flávio Cheim. Ideias e propostas de agilização da marcha processual. In: CARNEIRO, Athos Gusmão; CALMON, Petrônio (org.). Bases científicas para um renovado direito processual. 2 ed. Salvador: Juspodivm, 2009.

ABOLONIN, Vadim; YARKOV, Vladimir. Enforcement in Russia: a short outline. In: VAN RHEE, C.H.; UZELAC, Alan (coord.). Enforcement and enforceability - tradition and reform. Antwerp, Oxford, Portland: Intersentia, 2010.

ALBERTON, Genacéia da Silva. Repensando a jurisdição conflitual. In: CARNEIRO, Athos Gusmão; CALMON, Petrônio (org.). Bases científicas para um renovado direito processual. 2 ed. Salvador: Juspodivm, 2009.

ALEMÃO, Ivan. A reforma da execução em Portugal. Disponível em $<$ http://jus.com.br/revista/texto/10000/reforma-da-execucao-em-portugal>. Acesso em 09 out. 2012.

ALMEIDA, Cândido Mendes de. Codigo Philippino, ou, Ordenações e leis do Reino de Portugal: recopiladas por mandado d'El-Rey D. Philippe I. Rio de Janeiro: Typ. do Instituto Philomathico, 1870. Disponível em <http://www1.ci.uc.pt/ihti/proj/filipinas/ordenacoes.htm>. Acesso em 20 mar. 2015.

ALMEIDA, João Alberto de. Desjudicialização: a relação entre a arbitragem e os serviços notariais e registrais. Revista da Faculdade de Direito da Universidade Federal de Minas Gerais, Belo Horizonte, v. 59, junho-dezembro 2011.

ALMEIDA, Patrícia Martinez; SILVEIRA, Vladmir Oliveira da. Processo judicial eletrônico e segurança de dados: a proteção digital como novo direito humano. Revista mestrado em direito, Osasco, ano 13, n 2, p. 323-343, jul.-dez. 2013.

ALMEIDA E OLIVEIRA, Antonio. A Lei das Execuções ou consolidação e concordância das disposições, que, segundo a Lei n. 3272 de 5 de outubro de 1885 e o Regulamento $n$. 
9549 de 23 de janeiro de 1886, regem as acções hypothecaria e de penhor agrícola e as execuções commerciaes e civis em geral. Rio de Janeiro: B.L. Garnier, 1887.

ALVARO DE OLIVEIRA, Carlos Alberto (coord.). A nova execução de títulos extrajudiciais. Rio de Janeiro: Forense, 2006.

ALVIM, José Eduardo Carreira. Tutela específica das obrigações de fazer e não fazer na reforma processual. Belo Horizonte: Del Rey, 1997.

AMARAL, Guilherme Rizzo. Art. 689-A. In: ALVARO DE OLIVEIRA, Carlos Alberto (coord.). A nova execução de títulos extrajudiciais. Rio de Janeiro: Forense, 2006.

ANDRADE, Érico. As novas perspectivas do gerenciamento e da "contratualização" do processo. Revista de processo, São Paulo, ano 36, vol. 193, mar. 2011.

ANDRADE, Marco Antonio de. Direito processual civil paraguaio. In: SOARES, Carlos Henrique; CARVALHO DIAS, Ronaldo Brêtas de (coord.). Direito Processual Civil LatinoAmericano. Belo Horizonte: Arraes Editores, 2013.

ANDREWS, Neil. O moderno processo civil: formas judiciais e alternativas de resolução de conflitos na Inglaterra. 2 ed. São Paulo: RT, 2012.

; TURNER, Robert. The system of enforcement of civil judgments in England. In: VAN RHEE, C.H.; UZELAC, Alan (coord.). Enforcement and enforceability - tradition and reform. Antwerp, Oxford, Portland: Intersentia, 2010.

ARAÚJO, Fabrício Simão da Cunha. Direito processual civil colombiano. In: SOARES, Carlos Henrique; CARVALHO DIAS, Ronaldo Brêtas de (coord.). Direito Processual Civil Latino-Americano. Belo Horizonte: Arraes Editores, 2013.

ARONNE, Bruno da Costa. O impacto da informatização judicial sobre os princípios do processo civil. Revista eletrônica de direito processual, Rio de Janeiro, ano 2, vol. II, jan.dez. 2008.

ASSIS, Araken de. Cumprimento de Sentença. 4 ed. Rio de Janeiro: Forense, 2013. . Manual da execução. 14 ed. São Paulo: Editora Revista dos Tribunais, 2012. 
ASSUMPÇÃO, Letícia Franco Maculan. Função notarial e de registro: concurso público, regime jurídico e responsabilidade civil. Porto Alegre: Núria Fabris, 2011.

ÁVILA, Humberto. O que é “devido processo legal”? In: DIDIER JUNIOR, Fredie (coord.). Leituras complementares de Processo Civil. 8 ed. Salvador: Editora Juspodivm, 2010.

B

BABUNKSI, Vladimir. Reform of the enforcement procedure in the Republic of Macedonia. In: VAN RHEE, C.H.; UZELAC, Alan (coord.). Enforcement and enforceability - tradition and reform. Antwerp, Oxford, Portland: Intersentia, 2010.

BARBOSA MOREIRA, José Carlos. O futuro da justiça: alguns mitos. Revista da Academia Brasileira de Letras Jurídicas, Rio de Janeiro, v. 17, jan.-dez. 2001.

- O neoprivatismo no processo civil. In: DIDIER JUNIOR, Fredie (coord.). Leituras complementares de Processo Civil. 8 ed. Salvador: Editora Juspodivm, 2010.

O problema da duração dos processos: premissas para uma discussão séria. Revista Magister de Direito Civil e Processual Civil, Porto Alegre: Magister, v. 2, n. 12, p. 27-36, mai-jun. 2006.

Privatização do processo? Revista da EMERJ, Rio de Janeiro, v. 1, n. 3, p. 13/25, 1998, Disponível em http://www.emerj.tjrj.jus.br/revistaemerj_online/edicoes/revista03/revista03_13.pdf>, Acesso em 20 set. 2015.

BATISTA SANTOS, Guilherme Luis Quaresma. Contraditório e execução. Rio de Janeiro: Lumen Juris, 2013.

Teoria geral da execução e o Código de Processo Civil Brasileiro de 2015. In: DIDIER JUNIOR, Fredie (coord.). Novo CPC doutrina selecionada - v.5 execução. Salvador: Juspodivm, 2015. p. 42.

BAUMÖHL, Debora Ines Kram. A nova execução civil: a desestruturação do processo de execução. São Paulo: Atlas, 2006.

BECKER, L.A. Contratos bancários: execuções especiais. São Paulo: Malheiros, 2002. 
BEDAQUE, Jose Roberto dos Santos. Cognição e decisões do juiz no processo executivo. In: FUX, Luiz; NERY JUNIOR, Nelson; WAMBIER, Tereza Arruda Alvim (coord.). Processo e constituição: estudos em homenagem ao professor José Carlos Barbosa Moreira. São Paulo: Editora Revista dos Tribunais, 2006.

Direito e processo: influência do direito material sobre o processo. 6 ed. São Paulo: Malheiros, 2011. Efetividade do processo e técnica processual. 3 ed. São Paulo: Malheiros, 2010.

BENEDUZI, Pedro. Introdução ao processo civil alemão. Salvador: Editora Juspodivm, 2015.

BERMUDES, Sérgio. A reforma do código de processo civil. 2 ed. São Paulo: Saraiva, 1996. BESTER, Gisela Maria; HANS, Gabriela Damião Cavalli. As ações sincréticas como instrumento de celeridade processual: direitos fundamentais conexos e efetividade constitucional. In: GUNTHER, Luiz Eduardo (coord.). Jurisdição: crise, efetividade e plenitude institucional. Curitiba: Juruá, 2009.

BORGES, Marcus Vinícius Motter. A prevalência do interesse da execução: hipóteses controvertidas de cabimento da comissão do leiloeiro a partir de julgados do Superior Tribunal de Justiça. In: LAMY, Eduardo; ARAÚJO, José Henrique Mouta; BORGES, Marcus Vinícius Motter. Aspectos polêmicos da execução civil. São Paulo: Conceito Editorial, 2012.

BRANDELLI, Leonardo. Teoria geral do direito notarial (ebook). 4 ed. São Paulo: Saraiva, 2011.

BRESOLIN, Humberto Bara. Execução extrajudicial imobiliária: aspectos práticos. São Paulo: Atlas, 2013.

BUENO, Cassio Scarpinella. Novo Código de Processo Civil anotado. São Paulo: Saraiva, 2015 .

Projetos de Novo Código de Processo Civil comparados e anotados. São Paulo: Saraiva, 2014. 
C

CADENAS, Manuel Cachón. Apuntes de ejecución procesal civil. Barcelona: Universitat Autònoma de Barcelona, 2011.

. La ejecución procesal civil. Barcelona: Atelier Libros Juridicos, 2014.

CALAMANDREI, Piero. Direito Processual Civil-volume I. Campinas: Bookseller, 1999.

CÂMARA, Alexandre Freitas. A nova execução de sentença. 4 ed. Rio de Janeiro: Lumen Juris, 2007.

Lições de Direito Processual Civil - Volume II. 20 ed., Rio de Janeiro:

Lumen Juris, 2012.

CAMBI, Eduardo. Neoconstitucionalismo e neoprocessualismo. In: DIDIER JUNIOR,

Fredie (coord.). Leituras complementares de Processo Civil. 8 ed. Salvador: Editora Juspodivm, 2010.

CAMPOS, Isabel Menéres. As questões não resolvidas da reforma da acção executiva. Sub Judice: justiça e sociedade, Coimbra, no 29, out./dez. 2004.

CARMONA, Carlos Alberto. A arbitragem no processo civil brasileiro. São Paulo: Malheiros, 1993.

. Arbitragem e processo. 3 ed. São Paulo: Atlas, 2009.

CARNELUTTI, Francesco. Instituições do Processo Civil - Volume I. São Paulo: Classic Book, 2000.

CARVALHO, Milton Paulo de. Os princípios e um novo código de processo civil. In: CARNEIRO, Athos Gusmão; CALMON, Petrônio (org.). Bases científicas para um renovado direito processual. 2 ed. Salvador: Juspodivm, 2009.

CARVALHO FILHO, Milton Paulo de. Aplicação do princípio da proporcionalidade à execução, à luz das leis n. 11.232/2005 e 11.382/2006. In: CARVALHO, Milton Paulo de (coord.). Direito processual civil. São Paulo: Editora Quartier Latin, 2007.

CASTRO, Amílcar de. Comentários ao Código de Processo Civil. Vol. X. T. I. 2 ed. São Paulo: Forense, 1963. 
CATERINA, Rafaela Marjorie de Oliveira. Considerações sobre o processo executivo no direito comparado: a reforma executiva em Portugal e o título executivo europeu. Disponível em <http://ww.diritto.it/docs/33193-considera-es-sobre-o-processo-executivo-no-direitocomparado-a-reformaexecutiva-em-portugal-e-o-t-tulo-executivo-europeu>. Acesso em 05 mai. 2014.

CENEVIVA, Walter. Lei dos notários e dos registradores comentada (Lei n. 8935/94). 6 ed. São Paulo: Saraiva, 2007.

CHARDON, Mathieu. Enforcement in France: an overview of legislation and practice. In: VAN RHEE, C.H.; UZELAC, Alan (coord.). Enforcement and enforceability - tradition and reform. Antwerp, Oxford, Portland: Intersentia, 2010.

How to implement common standards of enforcement law? In: VAN RHEE, C.H.; UZELAC, Alan (coord.). Enforcement and enforceability - tradition and reform. Antwerp, Oxford, Portland: Intersentia, 2010.

Training judicial officers in France. In: VAN RHEE, C.H.; UZELAC, Alan (coord.). Enforcement and enforceability - tradition and reform. Antwerp, Oxford, Portland: Intersentia, 2010.

CHIOVENDA, Giuseppe. Instituições de direito processual civil. 4 ed. Campinas: Bookseller Editora, 2008.

CINTRA, Antonio Carlos de Araújo; GRINOVER, Ada Pellegrini; DINAMARCO, Cândido Rangel. Teoria geral do processo. 29 ed. São Paulo: Malheiros, 2013.

COELHO, Gláucia Mara. Direito processual civil costarriquenho. In: CRUZ E TUCCI, José Rogério (coord.). Direito processual civil americano contemporâneo. São Paulo: Lex Editora, 2010.

. Direito processual civil português. In: CRUZ E TUCCI, José Rogério (coord.). Direito processual civil europeu contemporâneo. São Paulo: Lex Editora, 2010.

. Notas sobre a execução de decisão judicial que determina o pagamento de quantia nos EUA e na Inglaterra. Revista Magister de Direito Civil e Processual Civil, Porto Alegre, ano VIII, nº 43, jul.-ago. 2011. 
CORRÊA. Fábio Peixinho Gomes. Direito processual civil mexicano. In: CRUZ E TUCCI, José Rogério (coord.). Direito processual civil americano contemporâneo. São Paulo: Lex Editora, 2010.

COSTA, Carla Regina Clark da. Direito processual civil uruguaio. In: SOARES, Carlos Henrique; CARVALHO DIAS, Ronaldo Brêtas de (coord.). Direito Processual Civil LatinoAmericano. Belo Horizonte: Arraes Editores, 2013.

CREMASCO, Suzana Santi; SILVA, Tiago Elder. O caráter jurisdicional da arbitragem e o precedente arbitral. Revista da Faculdade de Direito da Universidade Federal de Minas Gerais, Belo Horizonte, v. 59, junho-dezembro 2011.

CRUZ E TUCCI, José Rogério. Direito processual civil belga. In: CRUZ E TUCCI, José Rogério (coord.). Direito processual civil europeu contemporâneo. São Paulo: Lex Editora, 2010.

Direito processual civil inglês. In: CRUZ E TUCCI, José Rogério (coord.). Direito processual civil europeu contemporâneo. São Paulo: Lex Editora, 2010.

Garantias constitucionais da duração razoável e da economia processual no projeto do CPC. Revista Magister de Direito Civil e Processual Civil, Porto Alegre, ano VIII, nº 43, jul.-ago. 2011.

. Tutela processual do direito do executado (20 anos de vigência do CPC).

Revista da Ajuris, vol. 21, n. 61, p. 100-120, jul. 1994.

; AZEVEDO, Luiz Carlos de. Lições de história do processo civil lusitano. São Paulo: Editora Revista dos Tribunais, 2009.

D

DANTAS NETO, Renato de Magalhães. Autos virtuais: o novo layout do processo judicial brasileiro. Revista de Processo, São Paulo, ano 36, vol. 194, abr. 2011.

. Novo CPC e prioridade no uso dos meios eletrônicos: mais celeridade, mais tecnologia, mais justiça? In: DIDIER JUNIOR, Fredie; ADONIAS, Antonio (coord.). Projeto do novo código de processo civil- $2^{a}$ série. Salvador: Editora Juspodivm, 2012. 
DENARDI, Volnei Luiz. Execuções judicial e extrajudicial no sistema financeiro da habitação. São Paulo: Editora Revista dos Tribunais. 2009.

DIDIER JUNIOR, Fredie. Curso de direito processual civil - Volume 1. 14 ed. Salvador: Editora Juspodivm, 2012.

. Teoria do processo e teoria do direito: o neoprocessualismo. In: DIDIER

JUNIOR, Fredie (coord.). Teoria do processo: panorama doutrinário mundial - Volume 2. Salvador: Editora Juspodivm, 2010.

; BRAGA, Paula Sarno; OLIVEIRA, Rafael; CUNHA, Leonardo José

Carneiro da. Curso de direito processual civil - Execução - Volume 5. 4 ed. Salvador: Editora Juspodivm, 2012.

DINAMARCO, Cândido Rangel. A arbitragem na teoria geral do processo. São Paulo: Malheiros, 2013.

. A instrumentalidade do processo. 11 ed. São Paulo: Malheiros, 2003.

. Execução civil. 8 ed. São Paulo: Malheiros, 2002.

. Fundamentos do processo civil moderno - Tomo I. 5 ed. São Paulo:

Malheiros, 2002.

. Fundamentos do processo civil moderno - Tomo II. 5 ed. São Paulo:

Malheiros, 2002.

. Instituições de Direito Processual Civil - Volume I. 7 ed. São Paulo:

Malheiros, 2013.

. Instituições de Direito Processual Civil - Volume II. 6 ed. São Paulo:

Malheiros, 2009.

Instituições de Direito Processual Civil - Volume IV. 3 ed. São Paulo:

Malheiros, 2009.

. Nova era do processo civil. 4 ed. São Paulo: Malheiros, 2013. 
DOMBROSKI, Claudinei. Os princípios informadores da execução após a reforma do Código de Processo Civil. In: GUNTHER, Luiz Eduardo (coord.). Jurisdição: crise, efetividade e plenitude institucional. Curitiba: Juruá, 2009.

F

FABRÍCIO, Adroaldo Furtado. A alienação fiduciária de imóveis: aspectos processuais da Lei $n$. 9514/97. Disponível em < http://www.fabricioadvogados.com.br/artigos/art8.htm>. Acesso em 07 jul. 2015.

FIALHO, António José. Da teoria à prática - Algumas dificuldades na aplicação do novo regime da acção executiva. Sub Judice: justiça e sociedade, Coimbra, no 29, out./dez. 2004. FIGUEIRA JÚNIOR, Joel Dias. Execução simplificada e a desjudicialização do processo civil. In: ALVIM NETTO, José Manoel de Arruda; et al (coord.). Execução civil e temas afins do CPC/1973 ao Novo CPC: estudos em homenagem ao professor Araken de Assis. São Paulo: Editora Revista dos Tribunais, 2014.

- Projeto legislativo de novo código de processo civil e a crise da jurisdição. Revista dos Tribunais, São Paulo, v. 926, p. 455, dez. 2012.

FRAGA, Affonso. Theoria e pratica na execução das sentenças. São Paulo: C. Teixeira \& C. Editores, 1922.

FREITAS, Gabriela Oliveira. Direito processual civil peruano. In: SOARES, Carlos Henrique; CARVALHO DIAS, Ronaldo Brêtas de (coord.). Direito Processual Civil LatinoAmericano. Belo Horizonte: Arraes Editores, 2013.

FUCCI, Paulo Eduardo. Aspectos da alienação fiduciária de coisa imóvel. Revista dos Tribunais, São Paulo, v. 753, p. 848, jul. 1998.

FUENTE, Maria Consuelo Ruiz de la. El derecho constitucional a la ejecución de sentencias firmes. In: CADENAS, Manuel Cachón; JUNOY, Joan Picó. (coord.). La ejecución civil: problemas actuales. Barcelona: Atelier Libros Jurídicos, 2008.

G

GAIO JR., Antônio Pereira. Tutela específica das obrigações de fazer. Rio de Janeiro: Forense, 2000. 
GAJARDONI, Fernando da Fonseca. A revolução silenciosa da execução por quantia. Disponível em <http://www. jota.info/a-revolução-silenciosa-da-execução-por-quantia>. Acesso em 16 set. 2015.

Flexibilização procedimental: um novo enfoque para o estudo do procedimento em matéria processual. São Paulo: Atlas, 2008.

Técnicas de aceleração do processo. São Paulo: Lemos \& Cruz, 2003.

GARSON, Samy. A adequação da ideia de monopólio de jurisdição com os meios alternativos de solução de litígios. Disponível em <www.sgaa.adv.br/downloads/a_monopolio.pdf>. Acesso em 02 out. 2012.

A desjudicialização da execução hipotecária como meio alternativo de recuperação de créditos. 156 f. Dissertação (Mestrado em Ciências Jurídico-Processuais)Faculdade de Direito, Universidade de Coimbra, Coimbra, 2006.

A viabilidade de desjudicialização do processo de execução. In: CARVAlHO, Milton Paulo de (coord.). Direito processual civil. São Paulo: Editora Quartier Latin, 2007.

GERALDES, António Santos Abrantes. O juiz e a execução. Themis - Revista da Faculdade de Direito da UNL, Coimbra, ano V, $\mathrm{n}^{\circ}$ 09, mar. 2004.

GODOY, Arnaldo Sampaio de Moraes. A execução fiscal administrativa no Direito Tributário comparado. Belo Horizonte: Fórum, 2009.

GOLDSCHMIDT, James. Direito processual civil. Curitiba: Juruá, 2009.

GOMES, Manuel Tomé. Balanço da reforma da acção executiva. Sub Judice: justiça e sociedade, Coimbra, $\mathrm{n}^{\circ}$ 29, out./dez. 2004.

GOUVEIA, Ana Carolina Miguel. Common law no sistema jurídico americano: evolução, críticas e crescimento do direito legislado. Escola da Advocacia-Geral da União Ministro Victor Nunes Leal Publicações da Escola da AGU, $1^{\circ}$ Curso de Introdução ao Direito Americano: Fundamental of US Law Course, Brasília, Ano III, n. 12, set.-out. 2011.

GOUVEIA, Maria França. Poder geral de controlo. Sub Judice: justiça e sociedade, Coimbra, no 29, out./dez. 2004. 
GOZAINI, Osvaldo Alfredo. Características del juicio ejecutivo argentino: problemas actuales. In: CADENAS, Manuel Cachón; JUNOY, Joan Picó. (coord.). La ejecución civil: problemas actuales. Barcelona: Atelier Libros Jurídicos, 2008.

GRECO, Leonardo. A crise do processo de execução. In: FIUZA, César Augusto de Castro; SÁ, Maria de Fátima Freire de; DIAS, Ronaldo Brêtas C. Temas atuais de Direito Processual Civil. Belo Horizonte: Del Rey, 2001.

. A execução e a efetividade do processo. Revista de processo, São Paulo, ano 24, vol. 94, abr-jun. 1999.

. As garantias fundamentais do processo de execução fiscal. In: LOPES, João Batista; CUNHA, Leonardo Carneiro da (coord.). Execução civil (aspectos polêmicos). São Paulo: Dialética, 2005.

Novas perspectivas da efetividade e do garantismo processual. In: MITIDIERO, Daniel; AMARAL, Guilherme Rizzo (coord.). Processo Civil: estudos em homenagem ao Professor Doutor Carlos Alberto Alvaro de Oliveira. São Paulo: Editora Atlas, 2012.

O processo de execução: volume I. Rio de Janeiro: Renovar, 1999.

O processo de execução: volume II. Rio de Janeiro: Renovar, 2001.

GRINOVER, Ada Pellegrini. A inafastabilidade do controle jurisdicional e uma nova modalidade de autotutela. Revista Brasileira de Direito Constitucional, $\mathrm{n}^{\circ}$ 10, jul.-dez. 2007. Disponível em: <http://www.esdc.com.br/RBDC/RBDC-10/RBDC-10-013Ada_Pellegrini_Grinover.pdf>. Acesso em 23 mar. 2015.

. Novas tendências do direito processual de acordo com a Constituição de 1988. Rio de Janeiro: Forense Universitária, 1990.

GUERRA, Marcelo Lima. Execução forçada: controle de admissibilidade. 2 ed. São Paulo: Editora Revista dos Tribunais, 1998.

GUERRERO, Luis Fernando. Alternative dispute resolution e adequação ao momento histórico - a questão do acesso à justiça. In: CARNEIRO, Athos Gusmão; CALMON, Petrônio (org.). Bases científicas para um renovado direito processual. 2 ed. Salvador: Juspodivm, 2009. 
GURI, Elisabet Cerrato. La ejecución privada por entidade o persona especializada. In: CADENAS, Manuel Cachón; JUNOY, Joan Picó. (coord.). La ejecución civil: problemas actuales. Barcelona: Atelier Libros Jurídicos, 2008.

\section{$\mathbf{H}$}

HASSON, Roland; BACK, Hermínio. Crise na prestação jurisdicional: uma solução radical. In: GUNTHER, Luiz Eduardo (coord.). Jurisdição: crise, efetividade e plenitude institucional. Curitiba: Juruá, 2009.

HELENA, Eber Zoehler Santa. O fenômeno da desjudicialização. Jus Navigandi, Teresina, ano 11, n. 922, 11 jan. 2006. Disponível em <http://jus.com.br/artigos/7818>. Acesso em: 30 abr. 2014.

HENDERSON, Keith; SHAH, Angana; ELENA, Sandra; AUTHEMAN, Violaine. Regional Best Practices: enforcement of court judgments, lessons learned from Latin America. Washington: IFES, 2004. Disponível em < http://pdf.usaid.gov/pdf_docs/PBAAB593.pdf>. Acesso em 30 ago. 2015.

HENRIQUES, Antonio; MEDEIROS, João Bosco. Monografia no Curso de Direito. 7 ed. São Paulo: Editora Atlas, 2010.

HERNÁNDEZ, Nancy de la Fuente. Desjudicialización y procedimiento de realización de bienes embargados. In: CADENAS, Manuel Cachón; JUNOY, Joan Picó. (coord.). La ejecución civil: problemas actuales. Barcelona: Atelier Libros Jurídicos, 2008.

HESS, Burkhard. Different enforcement structures. In: VAN RHEE, C.H.; UZELAC, Alan (coord.). Enforcement and enforceability - tradition and reform. Antwerp, Oxford, Portland: Intersentia, 2010.

$\mathbf{J}$

JONGBLOED, Anthonie. The Dutch Court Bailiffs Act eight years after its introduction. In: VAN RHEE, C.H.; UZELAC, Alan (coord.). Enforcement and enforceability-tradition and reform. Antwerp, Oxford, Portland: Intersentia, 2010.

JORGE, Flavio Cheim. Relação processual e contraditório nas diversas espécies de execução. In: DIDIER JR., Fredie (coord.). Execução civil: estudos em homenagem ao professor Paulo Furtado. Rio de Janeiro: Editora Lumen Juris, 2006. 
K

KENNETT, Wendy. The enforcement of judgements in Europe. Oxford: Oxford University Press, 2000.

KNIJNIK, Danilo. Art. 685-C. In: ALVARO DE OLIVEIRA, Carlos Alberto (coord.). A nova execução de títulos extrajudiciais. Rio de Janeiro: Forense, 2006.

KOEHLER, Frederico Augusto Leopoldino. A razoável duração do processo. 2 ed. Salvador: Editora Juspodivm, 2013.

KRAMER, Xandra. Enhancing enforcement in the European Union. The European Order for payment procedure and its implementation in the Member States, particularly in Germany, the Netherlands and England. In: VAN RHEE, C.H.; UZELAC, Alan (coord.). Enforcement and enforceability - tradition and reform. Antwerp, Oxford, Portland: Intersentia, 2010.

L

LEÃO, Fernanda de Gouvêa. Arbitragem e execução. 139 f. Dissertação (Mestrado em Direito)-Faculdade de Direito, Universidade de São Paulo, São Paulo, 2012.

LEBRE DE FREITAS, José. A ação executiva à luz do Código de Processo Civil de 2013. 6 ed. Coimbra: Coimbra Editora, 2014.

A reforma do processo executivo. Revista da Ordem dos Advogados, Lisboa, Ano 62, vol. III, dez. 2002. Disponível em <http://www.oa.pt/Conteudos/Artigos/detalhe_artigo.aspx ?idc=1\&idsc=16886\&ida=16892 . Acesso em 05 mai. 2014.

. O primeiro ano de uma reforma executiva adiada. Sub Judice: justiça e sociedade, Coimbra, $\mathrm{n}^{\circ}$ 29, out./dez. 2004.

- Os paradigmas da Acção Executiva. Disponível em <http://www.dgpj.mj.pt/sections/informacao-e-eventos/anexos/professor-doutorlebre/downloadFile/file/plf.pdf?nocache=1210676672.22>. Acesso em 05 mai. 2014. . Penhora e oposição do executado. Themis - Revista da Faculdade de Direito da UNL, Coimbra, ano V, $\mathrm{n}^{\circ}$ 09, mar. 2004. 
Refoma da acção executiva - Parecer OA, 28 de março de 2008, Disponível em <http://www.inverbis.pt/2007-2011/advogados/reforma-accao-executivaparecer-oa.html>. Acesso em 05 mai. 2014.

LEMES, Selma. Análise da Pesquisa Arbitragem em Números de 2010 a 2013. Disponível em:

http://selmalemes.adv.br/artigos/An\%C3\%A1lise\%20da\%20Pesquisa\%20Arbitragem\%20e m\%20N\%C3\%BAmeros\%20-2010-2013.pdf >. Acesso em 05 dez. 2015.

LENZA, Pedro. Direito constitucional esquematizado. 17 ed. São Paulo: Saraiva, 2013.

LEONEL, Ricardo de Barros. Direito processual civil chileno. In: CRUZ E TUCCI, José Rogério (coord.). Direito processual civil americano contemporâneo. São Paulo: Lex Editora, 2010.

. Eficácia imediata da sentença e as reformas do CPC: um aspecto da caminhada para a efetividade da tutela jurisdicional. Justitia, São Paulo, v. 200, p. 125-143, 2009.

Reformas Recentes do Processo Civil: comentário sistemático. São Paulo: Método, 2007.

- Tutela jurisdicional diferenciada no Projeto de Novo Código de Processo Civil. Revista de Informação Legislativa, v. 190, p. 179-190, 2011.

LIEBMAN, Enrico Tullio. Estudos sobre o processo civil brasileiro. São Paulo: Bestbook, 2004.

Processo de execução. 5 ed. São Paulo: Saraiva, 1986.

LOBO DA COSTA, Moacir. Breve notícia histórica do Processo Civil brasileiro e de sua literatura. São Paulo: Editora Revista dos Tribunais, 1970.

LOPES, Carlos Córtes Vieira. Breves considerações acerca do sistema tributário nos Estados Unidos da América. Escola da Advocacia-Geral da União Ministro Victor Nunes Leal Publicações da Escola da AGU, $1^{\circ}$ Curso de Introdução ao Direito Americano: Fundamental of US Law Course, Brasília, Ano III, n. 12, set.-out. 2011. 
LUCON, Paulo Henrique dos Santos. Devido processo legal substancial. In: DIDIER JUNIOR, Fredie (coord.). Leituras complementares de Processo Civil. 8 ed. Salvador: Editora Juspodivm, 2010.

. Eficácia das decisões e execução provisória. São Paulo: Editora Revista dos Tribunais, 2000.

. Embargos à execução. São Paulo: Saraiva, 1996.

Nova execução de títulos judiciais e sua impugnação. In: WAMBIER, Teresa Arruda Alvim (coord.). Aspectos polêmicos da nova execução - 3: de títulos judiciais. São Paulo: Editora Revista dos Tribunais, 2006.

O novo perfil dos embargos à execução. In: CARNEIRO, Athos Gusmão; CALMON, Petrônio (org.). Bases científicas para um renovado direito processual. 2 ed. Salvador: Juspodivm, 2009.

Perfil histórico da execução civil. No prelo, disponibilizado para aproveitamento da disciplina Tutela Jurisdicional Executiva do Curso de Pós-Graduação stricto sensu da USP, 2010.

LUISO, Francesco P. Diritto processuale civile - Il processo executivo. 7 ed. Milão: Giuffrè Editore, 2013.

LUPOI, Michele Angelo. Enforcement of a claim with the support of the new information technology. Revista de processo, São Paulo, ano 36, vol. 193, mar. 2011.

; LUCON, Paulo Henrique dos Santos; COSTA, Guilherme Recena. Brazilian report on the use of new information technology in the enforcement of judgments. Revista de Processo, São Paulo, ano 36, vol. 194, abr. 2011.

M

MACHADO, Antônio Cláudio da Costa. Código de Processo Civil Interpretado: artigo por artigo, parágrafo por parágrafo. 12 ed. Barueri, São Paulo: Manole, 2013.

MACIEL JUNIOR, João Bosco. Aplicabilidade do princípio do contraditório nas relações particulares. São Paulo: Saraiva, 2009. 
MANCUSO, Rodolfo de Camargo. A resolução dos conflitos e a função judicial no contemporâneo Estado de Direito. 2 ed. São Paulo: Editora Revista dos Tribunais, 2014.

MARINONI, Luiz Guilherme. Controle do poder executivo do juiz. In: DIDIER JR., Fredie (coord.). Execução civil: estudos em homenagem ao professor Paulo Furtado. Rio de Janeiro: Editora Lumen Juris, 2006.

Curso de Processo Civil - Volume 1. 7 ed. São Paulo: Editora Revista dos Tribunais, 2013.

. Ideias para um "renovado direito processual". In: CARNEIRO, Athos Gusmão; CALMON, Petrônio (org.). Bases científicas para um renovado direito processual. 2 ed. Salvador: Juspodivm, 2009.

O direito à efetividade da tutela jurisdicional na perspectiva da teoria dos direitos fundamentais. Revista de Direito Processual Civil. Curitiba: Gênesis, abr.-jun. 2003.

; ARENHART, Sérgio Cruz. Curso de Processo Civil - Volume 3. 2 ed. São Paulo: Editora Revista dos Tribunais, 2008.

; ; MITIDIERO, Daniel. Novo curso de processo civil: tutela dos direitos mediante procedimento comum - volume II. São Paulo: Editora Revista dos Tribunais, 2015.

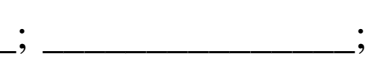
Novo curso de processo civil: tutela de direitos mediante procedimentos diferenciado - volume III. São Paulo: Editora Revista dos Tribunais, 2015.

MARQUES, Luiz Guilherme. O processo civil francês. São Paulo: Letras Jurídicas, 2013.

MARSTON, John. Fee systems for enforcement agents. In: VAN RHEE, C.H.; UZELAC, Alan (coord.). Enforcement and enforceability - tradition and reform. Antwerp, Oxford, Portland: Intersentia, 2010.

MARTÍN, Juan F. Garnica. Reparto de funciones entre juez y secretario em la ejucución. Disponível em <http://www.cejmjusticia.es/cej_dode/doc_users/pdf/nueva_oficina_judicial/ejecucion_civil/REPARTO_D E_FUNCIONES.pdf>. Acesso em 18 ago. 2015. 
MARTINS, Samir José Caetano. A execução extrajudicial de créditos do sistema de financiamento imobiliário. Revista eletrônica de direito processual, Rio de Janeiro, ano 2 , vol. II, jan.-dez. 2008.

MEIRELLES, Hely Lopes. Direito administrativo brasileiro. 37 ed. São Paulo: Malheiros, 2011.

MELlO, Celso Antônio Bandeira de. Curso de Direito Administrativo. São Paulo: Malheiros, 2010.

MENDES, Armindo Ribeiro. Execução e registro. Themis - Revista da Faculdade de Direito da UNL, Coimbra, ano V, nº 09, mar. 2004.

Forças e fraquezas do modelo português de acção executiva no limiar do século XXI - que modelo para o futuro? Supremo Tribunal de Justiça, 27 de maio de 2010 ,

Disponível

em

<http://www.stj.pt/ficheiros/coloquios/coloquiprocessocivil_ribeiromendes.pdf $>$. Acesso em 05 mai. 2014.

MENEZES, Nadja Lima. O direito fundamental à duração razoável do processo e a atuação judicial da administração pública brasileira como inspiração à adoção da súmula vinculante (stare decisis). Escola da Advocacia-Geral da União Ministro Victor Nunes Leal Publicações da Escola da AGU, $1^{\circ}$ Curso de Introdução ao Direito Americano: Fundamental of US Law Course, Brasília, Ano III, n. 12, set.-out. 2011.

MENEZES, Rafael Filipe Fonseca de. Direito processual civil mexicano. In: SOARES, Carlos Henrique; CARVALHO DIAS, Ronaldo Brêtas de (coord.). Direito Processual Civil Latino-Americano. Belo Horizonte: Arraes Editores, 2013.

MESQUITA, Lurdes. O título executivo europeu como instrumento de cooperação judiciária civil na União Europeia. Coimbra: Edições Almedina, 2012.

MINAMI, M.Y. Breves apontamentos sobre a generalização das medidas de efetivação no CPC/2015 - do processo para além da decisão. In: DIDIER JUNIOR, Fredie (coord.). Novo CPC doutrina selecionada - v.5.execução. Salvador: Juspodivm, 2015.

MORAES, José Rubens de. Direito processual civil suíço. In: CRUZ E TUCCI, José Rogério (coord.). Direito processual civil europeu contemporâneo. São Paulo: Lex Editora, 2010. 
. Direito processual civil uruguaio. In: CRUZ E TUCCI, José Rogério (coord.). Direito processual civil americano contemporâneo. São Paulo: Lex Editora, 2010. . Princípios da execução de sentença e reformas do Código de Processo Civil. Revista de Processo, São Paulo, ano 36, vol. 195, mai. 2011.

MOREIRA, Alberto Camiña. A execução para entrega de coisa. In: MOREIRA, Alberto Camiña et.al. Nova reforma processual civil comentada. 2 ed. São Paulo: Editora Método, 2003, p. 390.

Defesa sem embargos do executado: exceção de pré-executividade. 2 ed. São Paulo: Saraiva, 2000.

MUSCARI, Marco Antonio Botto. Efetividade da execução por quantia certa contra devedor solvente. 163 f. Tese (Doutorado em Direito)-Faculdade de Direito, Universidade de São Paulo, São Paulo, 2003.

$\mathbf{N}$

NERY JUNIOR, Nelson. Princípios do processo civil na Constituição Federal. 9 ed. São Paulo: Revista dos Tribunais, 2009.

NEVES, Daniel Amorim Assumpção. Manual de direito processual civil. 3 ed. São Paulo: Método, 2012.

. Novo Código de Processo Civil - Lei 13.105/2015. 2 ed. São Paulo: Método, 2015.

NITSCHKE JÚNIOR, Ademar; PAVELSKI, Ana Paula. Razoável duração do processo e responsabilidade do Estado. In: GUNTHER, Luiz Eduardo (coord.). Jurisdição: crise, efetividade e plenitude institucional. Curitiba: Juruá, 2009.

NOGUEIRA, Eliane Garcia. Juiz-gestor - Gestão judiciária e eficiência da justiça. Revista da Ajuris, Porto Alegre, Ano XXXVI, nº 113, mar. 2009.

NOVAES, Renato Rodrigues de. Direito processual civil boliviano. In: SOARES, Carlos Henrique; CARVALHO DIAS, Ronaldo Brêtas de (coord.). Direito Processual Civil LatinoAmericano. Belo Horizonte: Arraes Editores, 2013. 
OLIVEIRA, Guilherme José Braz de. Direito processual civil grego. In: CRUZ E TUCCI, José Rogério (coord.). Direito processual civil europeu contemporâneo. São Paulo: Lex Editora, 2010.

Direito processual civil peruano. In: CRUZ E TUCCI, José Rogério (coord.). Direito processual civil americano contemporâneo. São Paulo: Lex Editora, 2010.

$\mathbf{P}$

PAIVA, Eduardo; CABRITA, Helena. O processo executivo e o agente de execução. 3 ed. Coimbra: Coimbra Editora, 2013.

PAJIC, Natasa. Avenues for enforcement and execution of judgments in the United States. In: VAN RHEE, C.H.; UZELAC, Alan (coord.). Enforcement and enforceability - tradition and reform. Antwerp, Oxford, Portland: Intersentia, 2010.

PALACIO, Lino Henrique. Manual de derecho procesal civil. 20 ed. Buenos Aires: AbeledoPerrot, 2011.

PAMPLONA FILHO, Rodolfo; BARBOSA, Charles. Reflexões filosóficas sobre a neutralidade e imparcialidade no ato de julgar e o Projeto do Novo Código de Processo Civil. In: DIDIER JUNIOR, Fredie; ADONIAS, Antonio (coord.). Projeto do novo código de processo civil - $2^{a}$ série. Salvador: Editora Juspodivm, 2012.

PARENTONI, Leonardo Netto. A Celeridade no Projeto do novo CPC. Revista da Faculdade de Direito da Universidade Federal de Minas Gerais, Belo Horizonte, v. 59, junho-dezembro 2011.

PASSOS, J. J. Calmon de. A crise do poder judiciário e as reformas instrumentais: avanços e retrocessos. Revista Eletrônica sobre a Reforma do Estado, n. 3, set.-nov. 2005, Salvador, Disponível em <http://www.direitodoestado.com/revista/RERE-3-SETEMBRO-2005CALMON\%20DE\%20PASSOS.pdf>. Acesso em 15 nov. 2014.

PAVEZ, Macarena Vargas. Hacia la desjudicialización de la ejecución civil. Revista chilena de derecho, Santiago, v. 40, $\mathrm{n}^{\mathrm{o}}$ 01, abr. 2013, Disponível em $<$ http://www.scielo.cl/scielo.php?script=sci_arttext\&pid=S071834372013000100006\&lng=es\&nrm=iso>. Acesso em $1^{\mathrm{o}}$ jul. 2014. 
PEREIRA, Alex Costa. Técnicas de efetivação da tutela jurisdicional nas obrigações de pagamento de pecúnia. 169 f. Dissertação (Mestrado em Direito)-Faculdade de Direito, Universidade de São Paulo, São Paulo, 2008.

PICARDI, Nicola. Il giudice naturale principio fondamentale a livello europeo. In: DIDIER JUNIOR, Fredie (coord.). Teoria do processo: panorama doutrinário mundial - Volume 2. Salvador: Editora Juspodivm, 2010.

Jurisdição e processo. Rio de Janeiro: Forense, 2008.

. Manuale del Processo Civile. 3 ed. Milão: Giuffrè Editore, 2013.

PIMENTA, Paulo. Reflexões sobre a nova acção executiva. Sub Judice: justiça e sociedade, Coimbra, no 29 , out./dez. 2004.

POMAR, João Moreno. Desjudicialização e Desjurisdicionalização. Âmbito Jurídico, Rio Grande, XI, n. 54, jun 2008. Disponível em: <http://www.ambitojuridico.com.br/site/index.php?n_link=revista_artigos_leitura\&artigo_id=2814>. Acesso em 15 abr. 2014.

POPP, Carlyle. A efetividade da tutela jurisdicional, a dignidade humana e a independência do juiz. In: GUNTHER, Luiz Eduardo (coord.). Jurisdição: crise, efetividade e plenitude institucional. Curitiba: Juruá, 2009.

POZZA, Pedro. Art. 706. In: ALVARO DE OLIVEIRA, Carlos Alberto (coord.). A nova execução de títulos extrajudiciais. Rio de Janeiro: Forense, 2006.

PRADILlO, Juan Carlos Ortiz; RAGONE, Álvaro J. Perez. Código Procesal Civil Alemán (ZPO). Montevidéu: Konrad Adenauer Stiftung, 2006.

PRÜTTING, Hanns. Fundamentos y tendencias actuales en el desarrollo del Derecho Procesal Civil Europeo. Revista de Processo, São Paulo, ano 35, nº 190, dez. 2010.

Q

QUEIROGA, Onaldo Rocha de. Desjudicialização dos litígios. Rio de Janeiro: Renovar, 2012. 


\section{$\mathbf{R}$}

RAGONE, Álvaro Pérez. El modelo orgánico de la ejecución civil desjudicializada desde el punto de vista de Derecho Comparado. Mitos y realidades de la desjudicialización. Revista de Derecho de la Pontificia Universidad Católica de Valparaíso, 2012, no 38, p. 393-430, Disponível em <http://www.scielo.cl/scielo.php?script=sci_arttext\&pid=S0718$68512012000100010 \& \operatorname{lng}=$ es\&nrm=iso>. Acesso em 30 jun. 2014.

RAMOS, José Eduardo Ferreira. O sigilo bancário frente ao direito fundamental à tutela jurisdicional efetiva. In: GUNTHER, Luiz Eduardo (coord.). Jurisdição: crise, efetividade e plenitude institucional. Curitiba: Juruá, 2009.

REDONDO, Bruno Garcia; LOJO, Mário Vitor Suarez. Ainda e sempre a penhora on-line: constitucionalidade, princípios e procedimento. In: DIDIER JUNIOR, Fredie (coord.). Leituras complementares de Processo Civil. 8 ed. Salvador: Editora Juspodivm, 2010.

REETZ DE PAIVA, Daniela. A desjudicialização dos atos executórios. Escola da magistratura do estado do Rio de Janeiro - Série aperfeiçoamento de magistrados, Curso "Fomento Mercantil - Factoring", n. 9, Rio de Janeiro, out. 2011.

REGO, Carlos Lopes do. As funções e o estatuto processual do agente de execução e seu reflexo no papel dos demais intervenientes no processo executivo. Themis - Revista da Faculdade de Direito da UNL, Coimbra, ano V, nº 09, mar. 2004.

RIBEIRO, Darci Guimarães. La ejecución procesal civil: experiencia del derecho brasileño. In: CADENAS, Manuel Cachón; JUNOY, Joan Picó. La ejecución civil: problemas actuales. Barcelona: Atelier Libros Jurídicos, 2008.

RIBEIRO, Flávia Pereira. A desjudicialização da execução civil. São Paulo: Saraiva, 2013. Desjudicialização x Julgamento no STF sobre a (in)constitucionalidade do Decreto-Lei 70-66. Disponível em <http://atualidadesdodireito.com.br/flaviaribeiro/2011/08/23/desjudicializacao-Xjulgamento-no-stf-sobre-a-inconstitucionalidade-do-decreto-lei-7066/>. Acesso em 02 out. 2012.

RIOS GONÇALVES, Marcus Vinicius. Novo curso de direito processual civil - Volume 3. São Paulo: Saraiva, 2008. 
RODRIGUES, Luísa Maria. Processo Executivo: da execução fiscal desjurisdicionalização. 61 f. Dissertação (Mestrado em Ciências Jurídico-Económicas) Faculdade de Direito, Universidade do Porto, Porto, 2011.

RODRIGUES, Walter dos Santos. A duração razoável do processo na emenda constitucional $\mathrm{n}^{\mathrm{o}}$ 45. Revista eletrônica de direito processual, Rio de Janeiro, ano 2, vol. II, jan.-dez. 2008.

$\mathbf{S}$

SAAD, Renan Miguel. A alienação fiduciária sobre bens imóveis. Rio de Janeiro: Renovar, 2001.

SAMPAIO, J.M. Gonçalves. A acção executiva e a problemática das execuções injustas. 2 ed. Coimbra: Edições Almedina, 2008.

SAMPAIO JÚNIOR, José Herval. A influência da constitucionalização do direito no ramo processual: neoprocessualismo ou processo constitucional? Independente da nomenclatura adotada, uma realidade inquestionável. In: DIDIER JUNIOR, Fredie (coord.). Teoria do processo: panorama doutrinário mundial - Volume 2. Salvador: Editora Juspodivm, 2010.

SANTOS, Boaventura de Sousa. A justiça em Portugal: diagnóstico e terapêuticas. Manifesto, Lisboa, n. 7, p. 76-87, mar. 2005.

SANTOS, César Augusto dos. Breve abordagem sobre o tema da desjudicialização em busca de alternativas ao descongestionamento do Poder Judiciário. Disponível em <https://aplicacao.mpmg.mp.br/xmlui/bitstream/handle/123456789/1023/R\%20DJ\%20Tes e\%20desjudicializa\%C3\%A7\%C3\%A3o-c\%C3\%A9sar\%20augusto.pdf?sequence=1>. Acesso em 16 jun. 2014.

SANTOS, Ernane Fidélis dos. Alienação fiduciária de coisa imóvel. Revista Jurídica, Porto Alegre, vol. 47, n. 261, p.21-24, jul. 1999.

SCHENK, Leonardo Faria. Breve relato histórico das reformas processuais na Itália. Um problema constate: a lentidão dos processos cíveis. Revista eletrônica de direito processual, Rio de Janeiro, ano 2, vol. II, jan.-dez. 2008.

- Distribuição de competências no processo executivo português reformado. Revista eletrônica de Direito Processual, Rio de Janeiro, ano 3, vol. III, jan.-jun. 2009. 
SERRA, Miguel Dinis Pestana. Breve análise crítica de algumas das alterações ao regime da acção executiva portuguesa. Revista Jus Navigandi, Teresina, ano 14, n. 2369, 26 dez. 2009. Disponível em: <http://jus.com.br/artigos/14066>. Acesso em: 28 ago. 2015.

SHIMURA, Sérgio. Título executivo. 2 ed. São Paulo: Método, 2005.

SICA, Heitor Vitor Mendonça. Congestionamento viário e congestionamento judiciário. Revista de Processo, São Paulo, ano 39, v. 236, out. 2014.

Direito processual civil colombiano. In: CRUZ E TUCCI, José Rogério (coord.). Direito processual civil americano contemporâneo. São Paulo: Lex Editora, 2010. . Direito processual civil espanhol. In: CRUZ E TUCCI, José Rogério (coord.). Direito processual civil europeu contemporâneo. São Paulo: Lex Editora, 2010. . Efetividade da execução civil. Civil Procedure Review, v. 4, p. 161-190, 2013. O direito de defesa no Processo Civil brasileiro. São Paulo: Atlas, 2011. Perfis do contraditório e da ampla defesa na execução fiscal federal. Gestão e jurisdição: o caso da execução fiscal da União - Série "Diálogos para o desenvolvimento" v.9. CUNHA, Alexandre dos Santos; ALVES DA SILVA, Paulo Eduardo (coord.). Brasília: IPEA, p.209-222, 2013.

. Perspectivas atuais da "Teoria Geral do Processo". In: CARNEIRO, Athos Gusmão; CALMON, Petrônio (org.). Bases científicas para um renovado direito processual. 2 ed. Salvador: Juspodivm, 2009.

Tendências evolutivas da execução civil brasileira. Relatório preparado para o "I Colóquio Brasil-Itália de Direito Processual Civil”, São Paulo - SP, em 29 ago. 2014.

- Velhos e novos institutos fundamentais do direito processual civil. In: ZUFELATO, Camilo; YARSHELL, Flávio Luiz (Org.) 40 anos da teoria geral do processo no Brasil: passado, presente e futuro. São Paulo: Malheiros, 2013.

SILVA, Fernanda Tartuce da. Mediação nos conflitos civis. São Paulo: Método, 2008. 
SILVA, José Afonso da. Curso de Direito Constitucional positivo. 23 ed. São Paulo: Malheiros, 2004.

SILVA, Ovídio Araújo Baptista da. Execução obrigacional e mandamentalidade. Revista Páginas de Direito, Porto Alegre, ano 8, $\mathrm{n}^{\circ}$ 773, 21 de maio de 2008. Disponível em <http://www.tex.pro.br/artigos/65-artigos-mai-2008/5951-execucao-obrigacional-emandamentalidade>. Acesso em 02 dez. 2015.

Jurisdição e execução na tradição romano-canônica. 2 ed. São Paulo: Editora Revista dos Tribunais, 1997.

SILVA, Paulo Eduardo Alves da. Gerenciamento de processos judiciais. São Paulo: Saraiva, 2010.

SILVESTRI, Elisabetta. The devil is in the details: remarks on Italian enforcement procedures. In: VAN RHEE, C.H.; UZELAC, Alan (coord.). Enforcement and enforceability - tradition and reform. Antwerp, Oxford, Portland: Intersentia, 2010.

SIME, Stuart. A practical approach to civil procedure. 5 ed. Oxford: Oxford University Press, 2002.

SOARES NETO, Júlio. Direito registral e arbitragem: a nova jurisdição extrajudicial. Curitiba: Juruá, 2010.

SOUZA, Lígia Arlé Ribeiro de. A importância das serventias extrajudiciais no processo de desjudicialização. Disponível em <http://jus.com.br/revista/texto/20242/a-importancia-dasserventias-extrajudicias-no-processo-de-desjudicializacao>. Acesso em 07 out. 2012.

SOUZA, Marlene Marlei de. A efetividade da jurisdição. Revista da Ajuris, Porto Alegre, Ano XXXVI, nº 113, mar. 2009.

STRAPAZZON, Carlos Luiz. Ius imperi e iuris dictio: a natureza política da tutela jurisdicional. In: GUNTHER, Luiz Eduardo (coord.). Jurisdição: crise, efetividade $e$ plenitude institucional. Curitiba: Juruá, 2009.

SZKLAROWSKY, Leon Frejda. À luz da Constituição, é possível instituir validamente a execução do crédito tributário por autoridade diversa da jurisdicional? Jus Navigandi, Teresina, ano 13, n. 1920, 3 out. 2008. Disponível em: <http://jus.com.br/artigos/11794>. Acesso em 05 mai. 2014. 
TARZIA, Giuseppe. Il giusto processo di esecuzione. Rivista di Diritto Processuale, ano LVII, n. 2, abril-junho 2002.

O contraditório no processo executivo. Revista de processo, $\mathrm{n}^{\circ} 28$, ano 7, out.-dez. 1982.

TEIXEIRA, Paulo Duarte. Apresentação. Sub Judice: justiça e sociedade, Coimbra, ${ }^{\circ}$ 29, out./dez. 2004.

TEIXEIRA DE SOUZA, Miguel. Um novo processo civil português: à la recherche du temps perdu? Revista de Processo, v. 161, p. 203, jul. 2008.

TERRA, Marcelo. Alienação fiduciária de imóvel em garantia (lei $n^{\circ}$ 9.514/97, primeiras linhas). Porto Alegre: Sergio Antonio Fabris Editor, 1998.

THEODORO JÚNIOR, Humberto. As vias de execução no processo civil brasileiro. O cumprimento das sentenças e a execução dos títulos extrajudiciais visão do código atual e do projeto 8.046/2010 da Câmara dos Deputados. Revista de Processo, v. 201, p. 13, nov. 2013.

Curso de direito processual civil. 47 ed. Rio de Janeiro: Forense, 2007.

Processo de execução e cumprimento de sentença. 25 ed. São Paulo: Livraria e Editora Universitária de Direito, 2008.

TREPAT, Cristina Riba. La investigación judicial en la nueva ejecución civil. In: CADENAS, Manuel Cachón; JUNOY, Joan Picó. (coord.). La ejecución civil: problemas actuales. Barcelona: Atelier Libros Jurídicos, 2008.

TURNER, Robert. A model for an enforcement regime. The High Court enforcement officers of the Supreme Court of England and Wales. In: VAN RHEE, C.H.; UZELAC, Alan (coord.). Enforcement and enforceability - tradition and reform. Antwerp, Oxford, Portland: Intersentia, 2010. 
UZELAC, Alan. Privatization of enforcement services - A step forward for countries in transition? In: VAN RHEE, C.H.; UZELAC, Alan (coord.). Enforcement and enforceability - tradition and reform. Antwerp, Oxford, Portland: Intersentia, 2010.

$\mathbf{V}$

VAN RHEE, C.H. The history of the 'hussier de justice' in the Low Countries. In: VAN RHEE, C.H.; UZELAC, Alan (coord.). Enforcement and enforceability - tradition and reform. Antwerp, Oxford, Portland: Intersentia, 2010.

VASCONCELLOS, Pedro. Execução extrajudicial e judicial do crédito hipotecário no sistema financeiro da habitação. Rio de Janeiro: Livraria Francisco Alves Editora, 1976.

VERGUEIRO, Luiz Fabricio Thaumaturgo. Enforcement - Aspectos do cumprimento de decisões judiciais nos Estados Unidos da América. Escola da Advocacia-Geral da União Ministro Victor Nunes Leal Publicações da Escola da AGU, $1^{\circ}$ Curso de Introdução ao Direito Americano: Fundamental of US Law Course, Brasília, Ano III, n. 12, set.-out. 2011. VERKERK, Remme. Procedural fairness and compliance. In: VAN RHEE, C.H.; UZELAC, Alan (coord.). Enforcement and enforceability - tradition and reform. Antwerp, Oxford, Portland: Intersentia, 2010.

VIANA, Juvêncio Vasconcelos. Efetividade do processo: a execução em momentos distintos da reforma do CPC. In: LOPES, João Batista; CUNHA, Leonardo Carneiro da (coord.). Execução civil (aspectos polêmicos). São Paulo: Dialética, 2005.

W

WAMBIER, Luiz Rodrigues. Anotações sobre a crise do Processo de Execução - Algumas sugestões voltadas à sua efetividade. In: DIDIER JR., Fredie (coord.). Execução civil: estudos em homenagem ao professor Paulo Furtado. Rio de Janeiro: Editora Lumen Juris, 2006.

; TALAMINI, Eduardo. Curso avançado de Processo Civil - Volume 1.

13 ed. São Paulo: Editora Revista dos Tribunais, 2013. 
; TALAMINI, Eduardo. Curso avançado de Processo Civil - Volume 2.

13 ed. São Paulo: Editora Revista dos Tribunais, 2013.

WAMBIER, Teresa Arruda Alvim; CONCEIÇÃO; Maria Lúcia Lins; RIBEIRO; Leonardo Ferres da Silva; MELLO, Rogerio Licastro Torres de. Primeiros comentários ao novo código de processo civil: artigo por artigo. São Paulo: Editora Revista dos Tribunais, 2015. $\mathbf{Y}$

YARSHELL, Flávio Luiz. Tutela jurisdicional. 2 ed. São Paulo: DPJ Editora, 2006.

YOSHIKAWA, Eduardo Henrique de Oliveira. Execução extrajudicial e devido processo legal. São Paulo: Atlas, 2010.

$\mathbf{Z}$

ZACLIS, Lionel. Direito processual civil estadunidense. In: CRUZ E TUCCI, José Rogério (coord.). Direito processual civil americano contemporâneo. São Paulo: Lex Editora, 2010. Direito processual civil holandês. In: CRUZ E TUCCI, José Rogério (coord.). Direito processual civil europeu contemporâneo. São Paulo: Lex Editora, 2010.

ZAVASCKI, Teori Albino. Título executivo e liquidação. 2 ed. São Paulo: RT, 2001. 